DAGOBERTO YUKIO OKADA

\title{
Degradação de surfactante aniônico em reator UASB com água residuária de lavanderia
}

Tese apresentada à Escola de Engenharia de São Carlos da Universidade de São Paulo, como parte dos requisitos necessários para obtenção do título de Doutor em Ciências.

Área de concentração: Hidráulica e Saneamento

Orientadora: Profa. Dra. Maria Bernadete A. Varesche

VERSÃO CORRIGIDA

São Carlos

2012 
AUTORIZO A REPRODUÇÃO E DIVULGAÇÃO TOTAL OU PARCIAL DESTE TRABALHO, POR QUALQUER MEIO CONVENCIONAL OU ELETRÔNICO, PARA FINS DE ESTUDO E PESQUISA, DESDE QUE CITADA A FONTE.

Ficha catalográfica preparada pela Seção de Tratamento da Informação do Serviço de Biblioteca - EESC/USP

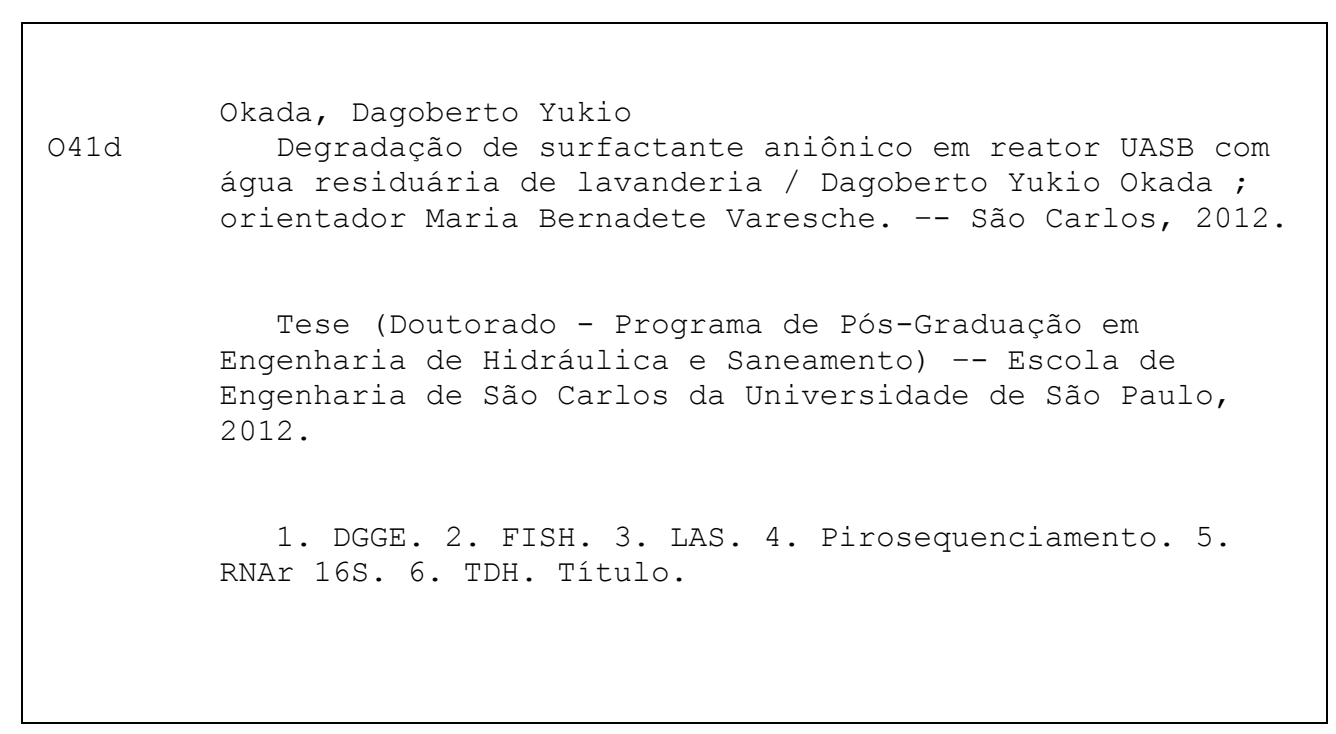




\section{FOLHA DE JULGAMENTO}

Candidato: Engenheiro DAGOBERTO YUKIO OKADA.

Título da tese: "Degradação de surfactante aniônico em reator UASB com água residuária de lavanderia".

Data da defesa: 25/07/2012

Comissão Julgadora:

Prof a $^{\text {. Dra }}$. Maria Bernadete Amâncio Varesche Silva (Orientadora) (Escola de Engenharia de São Carlos/EESC)

Prof. Titular Eugenio Foresti

(Escola de Engenharia de São Carlos/EESC)

Drª . Isabel Kimiko Sakamoto

(Escola de Engenharia de São Carlos/EESC)

$\mathrm{Dr}^{\mathrm{a}}$. Adriana Lopes dos Santos

(Pós-Doutorado/CNPQ)

Prof. Dr. Sérgio Francisco de Aquino

(Universidade Federal de Ouro Preto/UFOP)
Resultado:
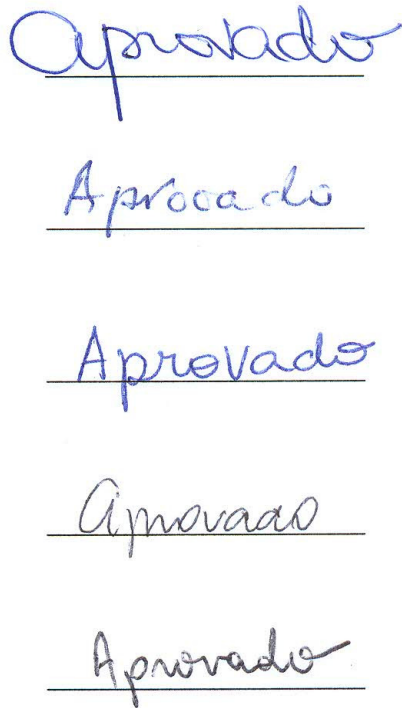

Coordenador do Programa de Pós-Graduação em Engenharia Hidráulica e Saneamento: Prof. Titular Edson Cezar Wendland

Presidente da Comissão de Pós-Graduação:

Prof. Titular Denis Vinicius Coury 
Aquele que conhece o outro é sábio.

Aquele que conhece a si mesmo é iluminado.

Aquele que vence o outro é forte.

Aquele que vence a si mesmo é poderoso.

Aquele que conhece a alegria é rico.

Aquele que conserva o seu caminho tem vontade.

Seja humilde, e permanecerás íntegro.

Curva-te, e permanecerás ereto.

Esvazia-te, e permanecerás repleto.

Gasta-te, e permanecerás novo.

O sábio não se exibe, e por isso brilha.

Ele não se faz notar, e por isso é notado.

Ele não se elogia, e por isso tem mérito.

E, porque não está competindo,

ninguém no mundo pode competir com ele.

(Lao Tsé - Tao Te Ching - Poema 22) 
Dedico aos meus pais, Jorge e Maria T. Okada, por todo apoio, incentivo e inspiração. 


\section{AGRADECIMENTOS}

À Fundação de Amparo à Pesquisa do Estado de São Paulo (FAPESP), pelo apoio concedido por meio de bolsa de mestrado (Processo no. 07/57674-2) e doutorado direto (Processo no. 09/50427-5).

À professora Dra. Maria Bernadete Varesche, pela oportunidade de desenvolver esse trabalho e pela orientação durante sua realização.

À professora Dra. Iolanda C. S. Duarte (Tininha), da UFSCar-Sorocaba, que apresentou o tema desse trabalho e pelo auxílio e sugestões durante sua realização.

Ao doutorando Tiago Palladino Delforno, pelo auxílio com as análises microbiológicas, pelas discussões e sugestões ao trabalho, e pelo convívio e amizade.

À Andressa dos Santos Esteves, pelo auxílio durante a realização desse trabalho, como iniciação científica.

À Dra. Isabel K. Sakamoto, técnica do Laboratório de Processos Biológicos (LPB), pelo auxílio na realização das análises de eletroforese em gel de gradiente desnaturante (denaturing gradient gel electrophoresis - DGGE) e número mais provável (NMP), e pela colaboração na discussão dos resultados das análises de microbiologia.

À Dra. Julia S. Hirasawa, pelo auxílio na realização da análise de hibridização fluorescente in situ (fluorescent in situ hybridization - FISH) e pela colaboração na montagem e operação do primeiro reator UASB desse trabalho. 
Às professoras Dra. Claudia Etchebehere Arenas e Dra. Angela Cabezas da Rosa, pela oportunidade de realização da análise de pirosequenciamento das amostras do presente estudo, e pela atenção e disposição durante o envio das amostras.

A Sra. Teresinha, responsável pela lavanderia comercial da qual foi coletada a água residuária, e aos funcionários da lavanderia, pela disposição em coletar o descarte de água das máquinas de lavar.

Ao Eduardo Blanco, primeiro pesquisador do grupo de surfactantes a trabalhar com água residuária de lavanderia, cuja experiência anterior foi de grande auxílio no ensaio usando água de lavanderia.

À professora Dra. Marcia Damianovic, pelas sugestões e comentários efetuados nos exames de qualificação de doutorado e mestrado.

Aos professores Edson Luiz Silva (Tininho), Eugenio Foresti, José Alberto Domingues Rodrigues, Marcelo Zaiat e Wyclef Dymurgo, pelos conselhos e experiências compartilhados. Às técnicas do LPB, Maria Angela Adorno (Janja) e Eloisa Pozzi (Elô), pelo suporte técnico, convívio e aprendizado.

Aos membros do grupo de surfactantes, pelo convívio e troca de experiências: Alana Lima, Amanda Tavares, Fabricio Moterani, Filipe Vasconcelos, Juliana Kawanishi, Juliana Polizel, Mariana Carosia, Lorena Oliveira, Mauricio Mayor, Rachel B. Costa e Thais Zaninetti.

A todos que conheci durante esse período, pela amizade, convívio e aprendizado: Adriana Gonçalves Ferreira, Adriana Maluf (Drica), Adys, Ariovaldo Silva (Ari), Arnaldo Sarti, Aurélia Oliveira Almeida, Beth Moraes, Bruna Moraes, Bruna S. Fernandes, Carol Zampol, Daniel Moureira, Daniele Vich, Débora Fonseca, Djalma Ferraz, Eduardo Penteado (Dú), Fabi Mestrinelli, Fernanda Ferraz, Flavia Bottino, Flavia Talarico Saia, Gabriel Souto, Giovana Tommaso, Glauce Pereira, Guilherme Peixoto, Gunther Brucha, Gustavo Mockaitis, 
Guto, Henrique (Muringa), Henrique Sonobe, Irene B. Sanchez, Jaime Alberto Sanchez (Beto), Jesus Garcia, Jorge Pantoja, José Alberto Côrrea Leite (Betão), Lênin, Liana Notari Pasqualini, Lívia Botta, Lucas Marcon, Luis Ricardo, Mara Rúbia, Marcell, Marcelo L. Garcia, Mariele, Mélida Del Pilar, Priscila Camiloti, Rafael Brito (Bazola), Raphael Medeiros, Renata Medici, Renata Rodrigues, Ricardo Almeida, Roberto Bezerra, Rodrigo Córdoba, Samantha Santos, Sandra Maintinguer, Tiago Martins, Theo Souza, Veronica Perna e Wilton Lopes.

Aos amigos Clarissa, Danilo, Diego Macedo, Diego Tella, Diego Vita, Fernanda Carvalho, Fernanda Rosa e Guararapes, pelo convívio e amizade desde os tempos da UFSCar.

À minha família, Jorge, Maria, Theófilo, Guilherme, Bete, Benjamin e Maria F. Campos, pelo apoio e compreensão durante a realização desse trabalho.

E a Deus pela permissão de realizar esse trabalho, e por todo auxílio e força imprescindíveis à sua realização. 


\section{RESUMO}

OKADA, D. Y. Degradação de surfactante aniônico em reator UASB com água residuária de lavanderia. 2012. 226 f. Tese (Doutorado) - Escola de Engenharia de São Carlos, Universidade de São Paulo, São Carlos, 2012.

Alquilbenzeno linear sulfonado (LAS) é um surfactante presente em água residuária de lavanderia. Em virtude da complexidade de sua degradação, o presente estudo envolveu a análise de alguns fatores, destacando-se: diversidade de co-substratos; tempo de detenção hidráulico (TDH); e concentração de co-substratos. Avaliou-se a degradação de LAS com diferentes co-substratos (metanol, etanol e extrato de levedura) em reator UASB, em TDH de $24 \mathrm{~h}$ e $14 \pm 2 \mathrm{mg} / \mathrm{L}$ de LAS. A influência de TDH e concentração de co-substratos foram analisadas em sete reatores UASB, com $12 \pm 3 \mathrm{mg} / \mathrm{L}$ de LAS; TDH de 6,35 e $80 \mathrm{~h}$, e diferentes concentrações de co-substratos (etanol, metanol e extrato de levedura), expressada pela carga orgânica específica (COE), entre 0,03 e 0,18 gDQO/gSTV.d. Ao final, avaliou-se a degradação de LAS em água residuária de lavanderia diluída, nessa mesma configuração de reator com TDH de $35 \mathrm{~h}$ e $10 \pm 5 \mathrm{mg} / \mathrm{L}$ de LAS. Em todos os ensaios foi utilizado inóculo granulado proveniente de reator UASB empregado no tratamento de água residuária de abatedouro de aves, mantendo-se intacta a forma granulada. No ensaio variando co-substratos, observou-se maior remoção de LAS $(50 \%)$ na presença de co-substrato complexo (extrato de levedura) que na presença de metanol e etanol (29-41\%). Diferença pouco significativa entre as comunidades do domínio Archaea e Bacteria (cerca de 60 e 40\%, respectivamente) foi observada na presença de diferentes co-substratos, mediante análise de hibridação fluorescente in situ (fluorescent in situ hybridization - FISH). Verificou-se maior influência da concentração de co-substratos na degradação de LAS, seguida pelo TDH. Aplicando a menor COE (0,03 gDQO/gSTV.d), obteve-se alta degradação de LAS (76\%), enquanto nos reatores variando TDH foram observadas eficiências de 18\% (6 h), 37-53\% (35 h) e 55\% (80 h). Nos reatores variando TDH e concentração de co-substratos, observou-se significativa remoção de LAS no separador de fases (20-53\%; na manta de lodo observou-se 13-43\%), relacionada à baixa concentração de co-substratos e condição anaeróbia facultativa nessa região. Por meio da técnica de PCR-DGGE (polymerase chain reaction - denaturing gradient gel electrophoresis) nas amostras do ensaio variando TDH e concentração de co-substratos, verificou-se maior coeficiente de similaridade na manta de lodo (Archaea: 70-90\%; Bacteria: 69-83\%), devido à estrutura de grânulo do inóculo utilizado. Verificou-se alta degradação de LAS (82\%) no reator com água de lavanderia, atribuída à diversidade de co-substratos (12 ácidos orgânicos voláteis detectados) e à concentração baixa desses co-substratos (COE: 0,03 gDQO/gSTV.d). Mediante análise de pirosequenciamento da região do RNAr $16 \mathrm{~S}$ de amostras do ensaio com água residuária de lavanderia foram encontrados 147 gêneros, dos quais 32 foram relacionados com a degradação de LAS (gêneros capazes de degradar compostos aromáticos, dessulfonação, $\beta$ e $\omega$-oxidação). Observou-se significativa abundância relativa $(>1 \%)$ dos seguintes gêneros relacionados com a degradação de LAS: Comamonas, Dechloromonas, Desulfovibrio, Gemmatimonas, Holophoga, Parvibaculum, Pseudomonas, Rhodanobacter, Sporomusa, Synergistes e Zoogloea. No separador de fases do reator com água de lavanderia, a alta remoção de LAS $(90 \%)$ e a abundância relativa dos gêneros aeróbios $(23 \%)$ e anaeróbios $(6 \%)$ relacionados com a degradação de LAS corroboraram a relação entre remoção de LAS e condição anaeróbia facultativa.

Palavras-chave: DGGE; FISH; LAS; Pirosequenciamento; RNAr 16S; TDH. 


\begin{abstract}
OKADA, D. Y. Degradation of anionic surfactant in UASB reactor with laundry wastewater. 2012. 226 f. Thesis (Doctoral) - Escola de Engenharia de São Carlos, Universidade de São Paulo, São Carlos, 2012.
\end{abstract}

Linear alkylbenzene sulfonate (LAS) is a surfactant present in laundry wastewater. Due to the complexity of its degradation, the present study involved the analysis of some features, highlighting: co-substrates diversity; hydraulic retention time (HRT); and co-substrates concentration. The LAS degradation with different co-substrates (methanol, ethanol and yeast extract) was evaluated in UASB reactor, at HRT of $24 \mathrm{~h}$ and LAS $14 \pm 2 \mathrm{mg} / \mathrm{L}$. The influence of HRT and concentration of co-substrates was analyzed in seven UASB reactors, with LAS $12 \pm 3 \mathrm{mg} / \mathrm{L}$; the HRT was 6,35 and $80 \mathrm{~h}$, and different concentration of co-substrates (methanol, ethanol and yeast extract), as specific organic load rate (SOLR) between 0.03 and $0.18 \mathrm{gCOD} / \mathrm{gTVS} . \mathrm{d}$. At the end, the LAS degradation was performed in UASB reactor fed with diluted laundry wastewater, at HRT of $35 \mathrm{~h}$ and LAS $10 \pm 5 \mathrm{mg} / \mathrm{L}$. In all assays was used a granular inoculum from a UASB reactor employed in treatment of wastewater from poultry slaughterhouse, maintaining the granular form. In the assay varying the co-substrates, it was observed greater LAS removal $(50 \%)$ in the presence of complex co-substrate (yeast extract) than in the presence of methanol and ethanol (removal: 29-41\%). Insignificant difference between the communities from Archaea and Bacteria domain (about 60 and 40\%, respectively) was observed in the presence of different co-substrates, according to the fluorescent in situ hybridization (FISH) analysis. It was verified greater influence of cosubstrates concentration than the HRT in the LAS degradation. At the lowest SOLR (0.03 gCOD/gTVS.d), high LAS degradation (76\%) was obtained while in the reactors varying the HRT were observed efficiencies of 18\% (6 h), 37-53\% (35 h) and 55\% (80 h). In the reactors varying the HRT and concentration of co-substrates, a significant LAS removal rate $(20-53 \%$; in the sludge blanket the rate was 13-43\%) was observed in the phase separator, related to the low concentration of co-substrates and the anaerobic facultative condition in this region. By the PCR-DGGE (polymerase chain reaction - denaturing gradient gel electrophoresis) technique of samples from the assay varying the HRT and concentration of co-substrates, it was verified great similarity coefficient in the sludge blanket (Archaea: 70-90\%; Bacteria: 69$83 \%$ ) due to the granule structure of the inoculum used. High LAS degradation (82\%) was verified in the reactor with laundry wastewater, which was attributed to the diversity of cosubstrates (12 organic volatile acids detected) and the low concentration of co-substrates (SOLR: 0.03 gCOD/gTVS.d). By pyrosequencing analysis of 16S RNAr genes in the samples from assay with laundry wastewater, it was found 147 genus, which 32 were related to the LAS degradation (genus able to degrade aromatic compounds, desulfonation, $\beta$ and $\omega$ oxidation). A significant relative abundance $(>1 \%)$ was observed in the following genus related to the degradation of LAS: Comamonas, Dechloromonas, Desulfovibrio, Gemmatimonas, Holophoga, Parvibaculum, Pseudomonas, Rhodanobacter, Sporomusa, Synergistes and Zoogloea. In the phases separator of the reactor with laundry wastewater, the high LAS removal (90\%) and the relative abundance of genus aerobic (23\%) and anaerobic $(6 \%)$ related to the degradation of LAS corroborated the relation between LAS removal and the anaerobic facultative condition.

Keywords: 16S RNAr; DGGE; FISH; HRT; LAS; Pyrosequencing. 


\section{LISTA DE FIGURAS}

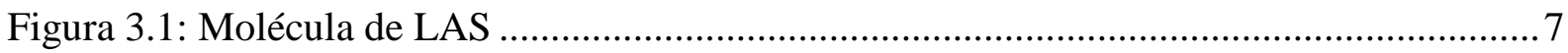

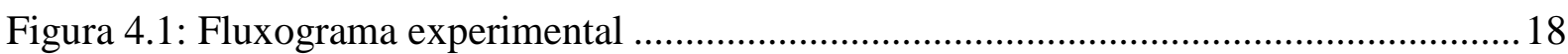

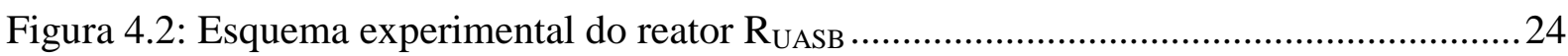

Figura 4.3: Frascos de alimentação (a) e reator $\mathrm{R}_{\mathrm{UASB}}$ durante operação (b) ...........................2 24

Figura 4.4: Esquema do reator UASB usado no experimento (a) e reatores UASB durante

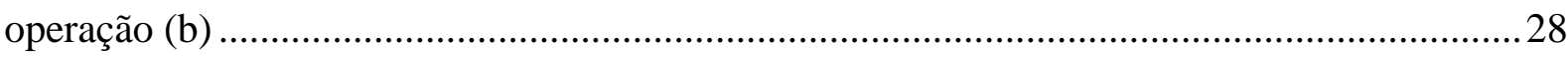

Figura 4.5: Esquema (a) e foto (b) do aparato para acúmulo de sólidos suspensos ................. 34 Figura 5.1: Isoterma de Freundlich (a) e Langmuir (b) para adsorção de LAS ao lodo granulado

Figura 5.2: Variação temporal de DQO afluente $(\square)$, efluente $(\bullet)$ e remoção $(\bullet)$ no reator

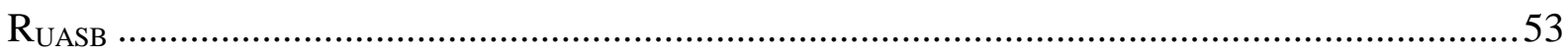

Figura 5.3: Variação temporal de LAS afluente $(\square)$, efluente $(\bullet)$ e remoção $(\bullet)$ no reator

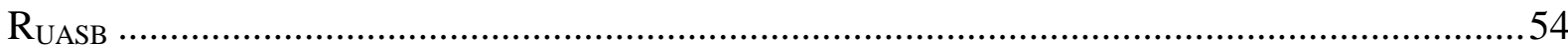

Figura 5.4: Variação temporal de ácido acético ( $\bullet$ ) e propiônico (०) no reator $\mathrm{R}_{\mathrm{UASB}}$.............55 Figura 5.5: Variação temporal da remoção de LAS $(\bullet)$ e relação AI/AP $(\boldsymbol{\Delta})$ no reator $\mathrm{R}_{\mathrm{UASB}}$

Figura 5.6: Distribuição do destino final de LAS no reator $\mathrm{R}_{\mathrm{UASB}}$ : efluente $(\square)$, adsorvido na

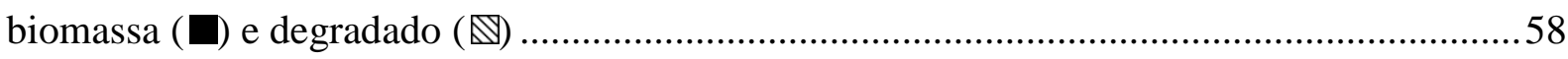

Figura 5.7: Imagem capturada de grânulos da manta de lodo 59

Figura 5.8: Box-plot para distribuição do diâmetro dos grânulos, no inóculo e Etapas I, II, IV e $\mathrm{V}$ do reator $\mathrm{R}_{\mathrm{UASB}}$, em amostra de 300 grânulos.

Figura 5.9: Morfologias observadas em amostras do reator $\mathrm{R}_{\mathrm{UASB}}$ : sarcinas fluorescentes semelhantes à Methanosarcina sp. (contraste de fase $-\mathrm{a}-\mathrm{e}$ fluorescência $-\mathrm{b}$ ), cocos fluorescentes (c), bacilos curvos, filamentos (d), bacilos retos, arranjo semelhantes à Methanosaeta sp. (e) e cocos (f).

Figura 5.10: Composição da comunidade microbiana do inóculo e de amostras do reator $\mathrm{R}_{\text {UASB }}$ para os domínios Archaea (ARC915) ( $\square$ ) e Bacteria (EUB338) ( $\mathbf{\square}$ ), com respectivo erro padrão e soma das percentagens $(\bullet)$ 
Figura 5.11: Campos microscópicos de amostra da Etapa II hibridada com a sonda ARC915 (a), coloração com DAPI (b) e contraste de fase (c)

Figura 5.12: Campos microscópicos de amostra da Etapa II hibridada com a sonda EUB338 (a), coloração com DAPI (b) e contraste de fase (c)

Figura 5.13: Box-plot de ácidos orgânicos voláteis detectados em 25 amostras de efluente dos

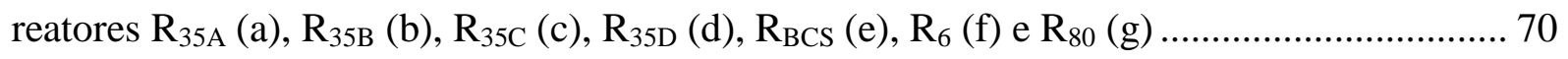
Figura 5.14: Grânulos da manta de lodo do reator $\mathrm{R}_{6}$ ao final da operação ............................ 71 Figura 5.15: Biomassa ao final do ensaio no separador de fases dos reatores $\mathrm{R}_{6}$ (a) e $\mathrm{R}_{\mathrm{BCS}}(\mathrm{b})$, cuja aparência foi similar ao observado em outros reatores (a aparente diferença entre a biomassa dos reatores $\mathrm{R}_{6}$ e $\mathrm{R}_{\mathrm{BCS}}$ deve-se às condiçãos de luz na captura das imagens) 72 Figura 5.16: Distribuição de sólidos ao final do ensaio: STV (目) e STF ( $\square$ ) na manta de lodo, e $\operatorname{STV}(\mathbb{\mathbb { Q }})$ e $\operatorname{STF}(\square)$ no separador de fases. 72

Figura 5.17: Reatores $R_{35 B}$ e $R_{35 C}$ (a), e separador de fases do reator $R_{35 C}$ (b) após adição de resazurina na alimentação 73

Figura 5.18: Distribuição do destino final de LAS: efluente ( $\square$ ), adsorvido na biomassa ( $\square$ ) e degradado $(\mathbb{\mathbb { Q }})$

Figura 5.19: Variação temporal de LAS afluente $(\square)$, efluente $(\diamond)$ e remoção $(\bullet)$ nos reatores $\mathrm{R}_{35 \mathrm{~A}}(\mathrm{a}), \mathrm{R}_{35 \mathrm{~B}}$ (b), $\mathrm{R}_{35 \mathrm{C}}$ (c), $\mathrm{R}_{35 \mathrm{D}}(\mathrm{d}), \mathrm{R}_{\mathrm{BCS}}(\mathrm{e}), \mathrm{R}_{6}$ (f) e $\mathrm{R}_{80}$ (g).... 75

Figura 5.20: Concentrações de LAS efluente dos reatores $R_{35 \mathrm{~A}}(\mathrm{a}), R_{35 \mathrm{~B}}(\mathrm{~b}), R_{35 \mathrm{C}}(\mathrm{c}), \mathrm{R}_{35 \mathrm{D}}(\mathrm{d})$, $\mathrm{R}_{\mathrm{BCS}}(\mathrm{e}), \mathrm{R}_{6}(\mathrm{f})$ e $\mathrm{R}_{80}(\mathrm{~g})$, ajustadas à sigmoide de Boltzmann 77

Figura 5.21: Manta de lodo no ponto de amostragem PA2 do reator $\mathrm{R}_{35 \mathrm{~A}}$ 78

Figura 5.22: Degradação específica de LAS em função da carga específica de LAS nos reatores $R_{35 A}, R_{35 B}, R_{35 C}, R_{35 D}(\square), R_{B C S}, R_{6}$ e $R_{80}(\boldsymbol{})$. Realizou-se regressão linear dos dados dos reatores $R_{35 A}, R_{35 B}, R_{35 C}$ e $R_{35 D}\left(R^{2}=0,9903\right)$...... 80

Figura 5.23: Degradação de LAS em função da concentração de ST (a), TDH (b) e carga orgânica específica (COE) (c).

Figura 5.24: Variação espacial de ácidos orgânicos voláteis no afluente (\$), pontos PA1 ( $\square$ ),

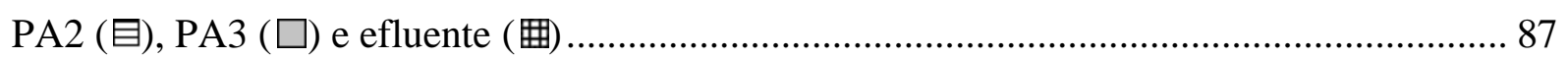

Figura 5.25: Remoção de LAS na manta de lodo $(\square)$ e no separador de fases $(\square)$................. 88 Figura 5.26: Relação entre remoção de LAS no separador de fases e degradação de LAS ..... 88 Figura 5.27: Remoção de LAS no separador de fases em função da concentração de ácidos orgânicos voláteis no ponto PA3 89 
Figura 5.28: Análise de cluster (Dice, UPGMA) do perfil das bandas padrões do DGGE dos fragmentos do RNAr 16S para o domínio Archaea (a) de amostras do inóculo, manta de lodo (ML) (b) e biomassa do separador de fases (SF) (c)

Figura 5.29: Análise de cluster (Dice, UPGMA) do perfil das bandas padrões do DGGE dos fragmentos do RNAr 16S para o domínio Bacteria (a) de amostras do inóculo, manta de lodo (ML) (b) e biomassa do separador de fases (SF) (c)

Figura 5.30: Morfologias observadas: sarcinas fluorescentes semelhantes à Methanosarcina sp. (contraste de fase - a - e fluorescência - b), bacilos (c), bacilos fluorescentes (d), arranjo semelhantes à Methanosaeta sp. (e), cistos (f) filamentos e espirilos (g)

Figura 5.31: Box-plot de LAS (a) e diluição aplicada (b) em 16 amostras de água residuária de lavanderia.

Figura 5.32: Box-plot de DQO bruta e filtrada (a), e ácidos orgânicos voláteis (b) em 16 amostras de água residuária de lavanderia

Figura 5.33: Box-plot de ácidos orgânicos voláteis detectados em 16 amostras de água residuária de lavanderia.

Figura 5.34: Box-plot de sólidos suspensos, dissolvidos e totais em 16 amostras de água residuária de lavanderia.....

Figura 5.35: Box-plot de fluoreto (a) e fosfato (b) em 16 amostras de água residuária de lavanderia. 101

Figura 5.36: Box-plot de NTK (a) e nitrato (b) em 16 amostras de água residuária de lavanderia. 101

Figura 5.37: Box-plot de sulfato (a) e sulfeto (b) em 16 amostras de água residuária de lavanderia.

Figura 5.38: Box-plot de pH (a), alcalinidade parcial e total (b) em 16 amostras de água residuária de lavanderia.

Figura 5.39: Box-plot de ácidos orgânicos voláteis em 23 amostras de efluente dos reatores $\mathrm{R}_{\mathrm{L} 1}$ (a) e $\mathrm{R}_{\mathrm{S} 1}$ (b)

Figura 5.40: Distribuição de sólidos ao final da Parte 1: STV (目) e STF ( $\square$ ) na manta de lodo, e STV $(\mathbb{\nabla})$ e $\operatorname{STF}(\square)$ no separador de fases

Figura 5.41: Biomassa na região do separador de fases aos 13 dias de operação nos reatores $\mathrm{R}_{\mathrm{L} 1}$ (a) e $\mathrm{R}_{\mathrm{S} 1}$ (b)

Figura 5.42: Coloração do efluente após a adição de resazurina no reator $\mathrm{R}_{\mathrm{S} 1}$ (a) e coletor de efluente dos reatores $\mathrm{R}_{\mathrm{L} 1}$ e $\mathrm{R}_{\mathrm{S} 1}(\mathrm{~b})$. 111 
Figura 5.43: Variação temporal de LAS afluente $(\square)$, efluente $(\bullet)$ e remoção $(\bullet)$, nos reatores $\mathrm{R}_{\mathrm{L} 1}$ (a) e $\mathrm{R}_{\mathrm{S} 1}$ (b).

Figura 5.44: Distribuição do destino final de LAS nos reatores $R_{L 1}$ e $R_{S 1}$ : efluente $(\square)$, adsorvido na biomassa $(\mathbb{\square})$ e degradado $(\mathbb{\mathbb { Q }})$

Figura 5.45: Degradação específica de LAS em função da carga específica de LAS nos reatores $R_{\mathrm{L} 1}$ e $R_{\mathrm{S} 1}(\mathbf{})$ comparada com a equação 5.1 (regressão linear dos reatores $R_{35 \mathrm{~A}}, \mathrm{R}_{35 \mathrm{~B}}$, $\mathrm{R}_{35 \mathrm{C}}$ e $\mathrm{R}_{35 \mathrm{D}}$; $\square$; item 5.3)

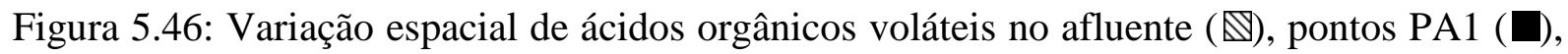
PA2 (目), PA3 ( $\square$ ) e efluente (团), nos reatores $\mathrm{R}_{\mathrm{L} 1}$ e $\mathrm{R}_{\mathrm{S} 1}$

Figura 5.47: Remoção de LAS na manta de lodo $(\square)$ e no separador de fases $(\square)$, nos reatores $\mathrm{R}_{\mathrm{L} 1}$ e $\mathrm{R}_{\mathrm{S} 1}$ 116

Figura 5.48: Remoção de LAS no separador de fases em função da concentração de ácidos orgânicos voláteis no ponto PA3 dos reatores $\mathrm{R}_{\mathrm{L} 1}$ e $\mathrm{R}_{\mathrm{S} 1}$, comparada com dados dos reatores $\mathrm{R}_{35 \mathrm{~A}}, \mathrm{R}_{35 \mathrm{~B}}, \mathrm{R}_{35 \mathrm{C}}, \mathrm{R}_{35 \mathrm{D}}, \mathrm{R}_{\mathrm{BCS}}$ e $\mathrm{R}_{80}(\square$; item 5.3). 117

Figura 5.49: Distribuição do diâmetro dos grânulos nos reatores $\mathrm{R}_{\mathrm{L} 2}$ e $\mathrm{R}_{\mathrm{S} 2}$ no início e fim do ensaio, em amostra de 400 grânulos 118

Figura 5.50: Manta de lodo do reator $\mathrm{R}_{\mathrm{L} 2}$ ao final do ensaio. 119

Figura 5.51: Box-plot de ácidos orgânicos voláteis detectados no efluente dos reatores $\mathrm{R}_{\mathrm{L} 2}$ Etapa 2.1 (a; em 10 amostras), $\mathrm{R}_{\mathrm{L}_{2}}$-Etapa 2.2 (b; em 19 amostras) e $\mathrm{R}_{\mathrm{S} 2}$ (c; em 29 amostras)

Figura 5.52: Variação temporal de DQO afluente ( $\square$ ), efluente $(\bullet)$ e remoção $(\bullet)$, no reator $\mathrm{R}_{\mathrm{L} 2}$

Figura 5.53: Distribuição de sólidos ao final da Parte 2: STV (目) e STF ( $\square$ ) na manta de lodo, e $\operatorname{STV}(\mathbb{\mathbb { Q }})$ e $\operatorname{STF}(\square)$ no separador de fases.

Figura 5.54: Variação temporal de sulfato afluente $(\square)$, efluente $(\diamond)$ e remoção $(\bullet)$, no reator $\mathrm{R}_{\mathrm{L} 2}$ 123

Figura 5.55: Variação temporal de sulfeto afluente $(\square)$ e efluente $(\diamond)$, no reator $\mathrm{R}_{\mathrm{L} 2}$ 124 Figura 5.56: Variação temporal de LAS afluente $(\square)$, efluente $(\bullet)$ e remoção $(\bullet)$, nos reatores $\mathrm{R}_{\mathrm{L} 2}(\mathrm{a})$ e $\mathrm{R}_{\mathrm{S} 2}(\mathrm{~b})$.

Figura 5.57: Distribuição do destino final de LAS nos reatores $R_{L 2}$ e $R_{S 2}$ : efluente $(\square)$, adsorvido na biomassa $(\square)$ e degradado $(\mathbb{Q})$ 126 
Figura 5.58: Degradação específica de LAS em função da carga específica de LAS nos reatores $R_{\mathrm{L} 2}$ e $R_{\mathrm{S} 2}(\mathbf{m})$, comparada com a equação 5.1 (regressão linear dos reatores $R_{35 \mathrm{~A}}, \mathrm{R}_{35 \mathrm{~B}}$, $\mathrm{R}_{35 \mathrm{C}}$ e $\mathrm{R}_{35 \mathrm{D}}$; $\square$; item 5.3)

Figura 5.59: Variação espacial de ácidos orgânicos voláteis no afluente (\$), pontos PA1

PA2 (目), PA3 ( $\square$ ) e efluente (曲), nos reatores $\mathrm{R}_{\mathrm{L} 2}$ e $\mathrm{R}_{\mathrm{S} 2}$

Figura 5.60: Remoção de LAS na manta de lodo (ם) e no separador de fases $(\square)$, nos reatores $\mathrm{R}_{\mathrm{L} 2}$ e $\mathrm{R}_{\mathrm{S} 2}$

Figura 5.61: Histograma da distribuição do comprimento das sequências 131

Figura 5.62: Curva de rarefação definida para similaridade de 97\% (a), 95\% (b), 90\% (c) e $80 \%$ (d), das sequências de amostras da manta de lodo (ML-RL1) e biomassa do separador de fases (SF-RL1) do reator $\mathrm{R}_{\mathrm{L} 1}$, e da manta de lodo (ML-RS1) e biomassa do separador de fases (SF-RS1) do reator $\mathrm{R}_{\mathrm{S} 1}$

Figura 5.63: Dendrogramas baseados nos índices de Bray-Curtis, UniFrac não ponderado e UniFrac ponderado para as amostras da manta de lodo (ML-RL1) e biomassa do separador de fases (SF-RL1) do reator $\mathrm{R}_{\mathrm{L} 1}$, e da manta de lodo (ML-RS1) e biomassa do separador de fases (SF-RS1) do reator $\mathrm{R}_{\mathrm{S} 1}$, para similaridade de $97 \%$

Figura 5.64: Abundância relativa de filo (similaridade 97\%) nas amostras da manta de lodo ( $\mathbb{Q}$ ) e biomassa do separador de fases $(\boldsymbol{\square})$ do reator $\mathrm{R}_{\mathrm{L} 1}$, e da manta de lodo (目) e biomassa do separador de fases $(\square)$ do reator $\mathrm{R}_{\mathrm{S} 1}$

Figura 5.65: Abundância relativa dos 20 gêneros mais frequentes na amostra da manta de lodo do reator $\mathrm{R}_{\mathrm{L} 1}$ (similaridade $97 \%$ ) 142

Figura 5.66: Abundância relativa dos 20 gêneros mais frequentes na amostra da manta de lodo do reator $\mathrm{R}_{\mathrm{S} 1}$ (similaridade $97 \%$ ).

Figura 5.67: Abundância relativa dos 20 gêneros mais frequentes na amostra da biomassa do separador de fases do reator $\mathrm{R}_{\mathrm{L} 1}$ (similaridade 97\%) 148

Figura 5.68: Abundância relativa dos 20 gêneros mais frequentes na amostra da biomassa do separador de fases do reator $\mathrm{R}_{\mathrm{S} 1}$ (similaridade $97 \%$ ). 152 Figura 5.69: Condição dos gêneros relacionados com a degradação de LAS, segundo a soma de abundâncias relativas nas amostras da manta de lodo $(\mathbb{\nabla})$ e biomassa do separador de fases ( $\square$ ) do reator $\mathrm{R}_{\mathrm{L} 1}$, e da manta de lodo (目) e biomassa do separador de fases $(\square)$ do reator $\mathrm{R}_{\mathrm{S} 1}$

Figura 5.70: Temperatura ótima de crescimento dos gêneros relacionados com a degradação de LAS 163 
xviii

Figura 5.71: pH ótimo de crescimento dos gêneros relacionados com a degradação de LAS 164

Figura 5.72: Abundância relativa de gêneros relacionados com a degradação de LAS nas amostras da manta de lodo $(\mathbb{Q})$ e biomassa do separador de fases $(\boldsymbol{\square})$ do reator $\mathrm{R}_{\mathrm{L} 1}$, e da

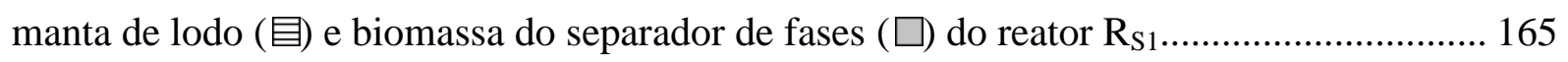




\section{LISTA DE TABELAS}

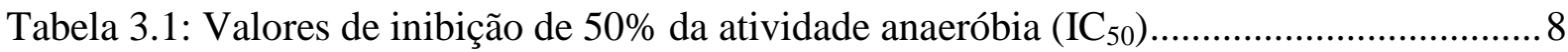

Tabela 3.2: Aplicação do reator UASB no tratamento de águas residuárias contendo LAS ... 14

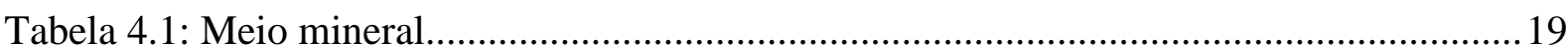

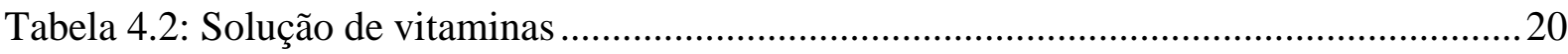

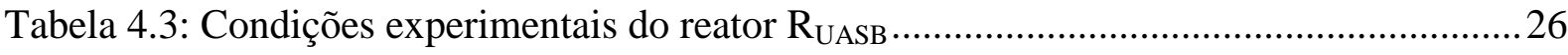

Tabela 4.4: Condições experimentais do ensaio variando a concentração de biomassa ..........29

Tabela 4.5: Condições experimentais do ensaio variando o TDH e a concentração de co-

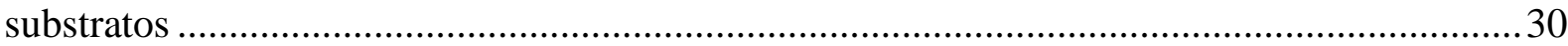

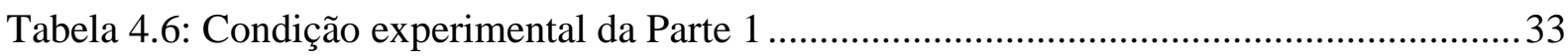

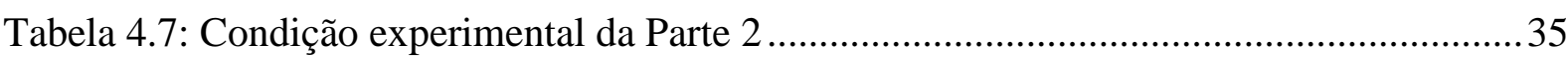

Tabela 4.8: Parâmetros físico-químicos monitorados ............................................................ 38

Tabela 4.9: Sondas de oligonucleotídeos para hibridação in situ fluorescente ........................42

Tabela 4.10: Concentrações finais de cada sonda ...................................................................42

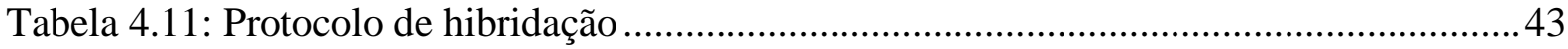

Tabela 4.12: Condições utilizadas na PCR para o domínio Archaea e Bacteria .......................44

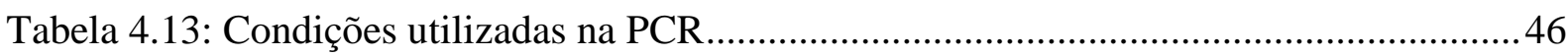

Tabela 4.14: Soluções para amplificação usando iniciadores $27 \mathrm{f}$ e $1100 \mathrm{r}$................................46

Tabela 4.15: Barcode de referências das amostras da manta de lodo (ML) e biomassa do separador de fases $(\mathrm{SF})$ dos reatores $\mathrm{R}_{\mathrm{L} 1}$ e $\mathrm{R}_{\mathrm{S} 1}$

Tabela 5.1: Ajuste dos dados de adsorção de LAS ao lodo granulado às equações de

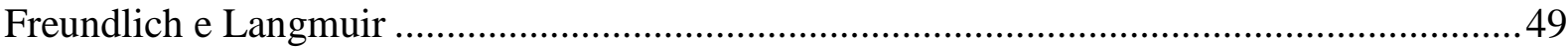

Tabela 5.2: Médias e desvios padrão dos parâmetros analisados no reator $\mathrm{R}_{\mathrm{UASB}}$...................52

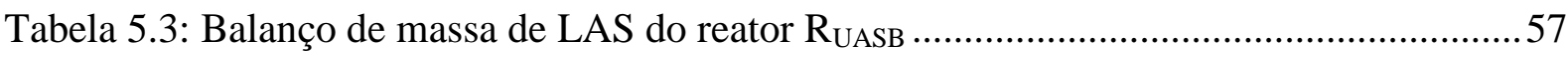

Tabela 5.4: Parâmetros analisados nos reatores variando a biodisponibilidade de LAS ......... 68

Tabela 5.5: Parâmetros analisados nos reatores variando TDH e concentração de co-substratos

Tabela 5.6: Balanço de massa de LAS 74

Tabela 5.7: Concentração de LAS adsorvido no inóculo e na biomassa ao final da operação 78 
Tabela 5.8: Comparação de degradação específica de LAS

Tabela 5.9: Matriz de correlação entre concentração de sólidos totais (ST), TDH, carga

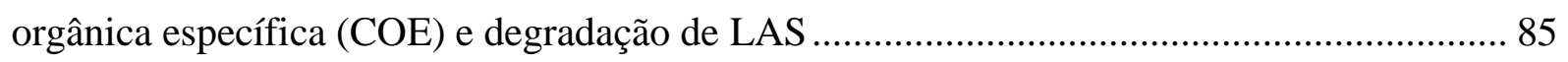

Tabela 5.10: Caracterização da água residuária de lavanderia ............................................ 104

Tabela 5.11: Ácidos orgânicos voláteis detectados na água residuária de lavanderia ........... 105

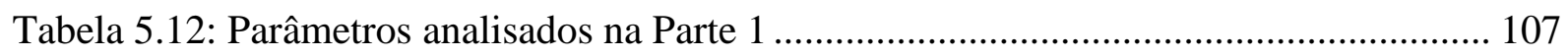

Tabela 5.13: Sólidos dos reatores $\mathrm{R}_{\mathrm{L} 1}$ e $\mathrm{R}_{\mathrm{S} 1}$, no início e fim do ensaio ............................... 109

Tabela 5.14: Concentração de LAS adsorvido na Parte 1................................................... 111

Tabela 5.15: Balanço de massa de LAS na Parte 1 ............................................................. 113

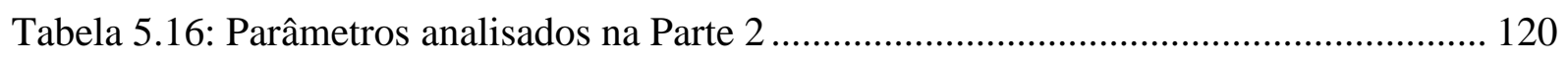

Tabela 5.17: Concentração de LAS adsorvido na Parte 2 .................................................. 126

Tabela 5.18: Balanço de massa de LAS na Parte 2 ........................................................... 127

Tabela 5.19: Quantidade de sequências e UTOs atribuídas para cada amostra ..................... 131

Tabela 5.20: Índices de diversidade determinados no nível de $97 \%$ de similaridade, nas

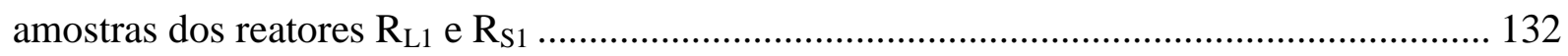

Tabela 5.21: Comparação entre estimadores de riqueza...................................................... 134

Tabela 5.22: Porcentagem de UTOs (similaridade 97\%) e sequências classificadas

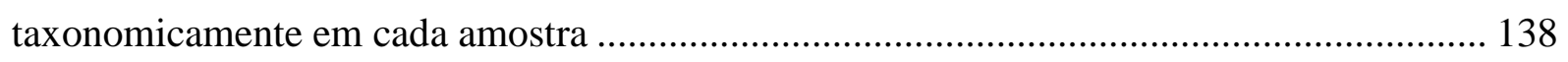

Tabela 5.23: Quantidade de gêneros classificados em cada amostra (similaridade 97\%) ..... 139

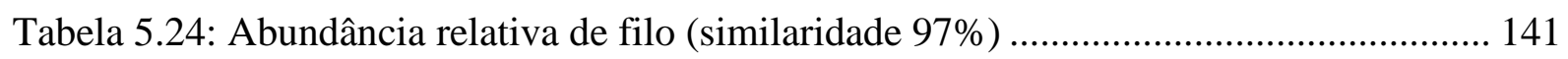

Tabela 5.25: Descrição dos 20 gêneros de maior abundância relativa na amostra da manta de

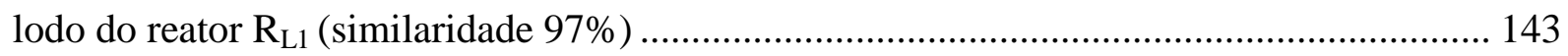

Tabela 5.26: Descrição dos 20 gêneros de maior abundância relativa na amostra da manta de lodo do reator $\mathrm{R}_{\mathrm{S} 1}$ (similaridade $97 \%$ ) 146

Tabela 5.27: Descrição dos 20 gêneros de maior abundância relativa da amostra da biomassa do separador de fases do reator $\mathrm{R}_{\mathrm{L} 1}$ (similaridade $97 \%$ ). 149

Tabela 5.28: Descrição dos 20 gêneros de maior abundância relativa da amostra da biomassa

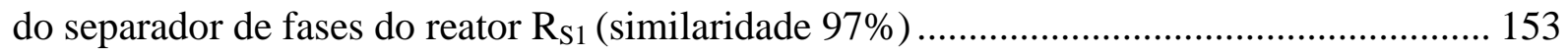

Tabela 5.29: Descrição de gêneros capazes de degradação de compostos aromáticos (fenol, tolueno, benzaldeído, hidroxi-, metoxi- e benzoatos), relacionados com a presença em estudos com LAS (referências em negrito) 156

Tabela 5.30: Descrição de gêneros capazes de reações de dessulfonação, $\beta$ e $\omega$ - oxidação, relacionados com a presença em estudos com LAS (ref. em negrito) 158 
Tabela 5.31: Descrição dos gêneros relacionados com a degradação de LAS.

Tabela 5.32: Abundância relativa de gêneros relacionados com a degradação de compostos aromáticos, dessulfonação, $\beta$ e $\omega$-oxidação

Tabela 5.33: Gêneros relacionados com a degradação de outros compostos aromáticos, relacionados com a presença em estudos com LAS (ref. em negrito). 168 Tabela 5.34: Abundância relativa de gêneros relacionados com a degradação de LAS e outros compostos aromáticos 


\title{
LISTA DE ABREVIATURAS E SIGLAS
}

\author{
ABS Alquilbenzeno sulfonado (ramificado) \\ AI Alcalinidade intermediaria \\ AOV Ácidos orgânicos voláteis \\ AP Alcalinidade parcial \\ AR Água residuária
}

ARC915 Sonda de oligonucleotídeo complementar ao RNAr de membros do domínio Archaea

CG Cromatografia gasosa

CLAE Cromatografia líquida de alta eficiência

CMC Concentração micelar crítica

COE Carga orgânica específica

CSTR Continuous stirred-tank reactor (reator de tanque agitado contínuo)

DAPI 4', 6-diadimino-2-fenil indol

DGGE Denaturing gradient gel electrophoresis (Eletroforese em gel de gradiente desnaturante)

DHP Dihidroxipiridina

DQO Demanda química de oxigênio

EDTA Ácido etilenodiamino tetracético

EESC Escola de Engenharia de São Carlos

EGSB Expanded granular sludge bed (Reator de leito granular expandido)

ETE Estação de tratamento de esgoto

EUB338 Sonda de oligonucleotídeo complementar ao RNAr de membros do domínio Bacteria

FAPESP Fundação de Amparo à Pesquisa do Estado de São Paulo

FISH Fluorescent in situ hybridization (hibridação fluorescente in situ)

$\mathrm{IC}_{50} \quad 50 \%$ da concentração máxima de inibição

INDEAR Instituto de Agrobiotecnologia Rosario

LAS Alquilbenzeno linear sulfonado 
LPB Laboratório de Processos Biológicos

mg HAc Equivalente a ácido acético

mg DQO Equivalente a DQO

ML-RL1 Amostra da manta de lodo do reator $\mathrm{R}_{\mathrm{L} 1}$

ML-RS1 Amostra da manta de lodo do reator $\mathrm{R}_{\mathrm{S} 1}$

ND Não detectado

NMP Número mais provável

NON338 Sonda de oligonucleotídeo não complementar ao RNAr, utilizado como controle negativo

NTK Nitrogênio total Kjeldahl

PAH Polycyclic Aromatic Hydrocarbon (Hidrocarboneto aromático policíclico)

$\mathrm{pb} \quad$ Pares de base

PBS Tampão fosfato salino

PCP Penta cloro fenol

PCR Polymerase chain reaction (Reação de polimerização em cadeia)

PET Politereftalato de etileno

$\mathrm{pH} \quad$ Potencial hidrogeniônico

QIIME Quantitative Insights Into Microbial Ecology

RAHLF Reator anaeróbio horizontal de leito fixo

RDP Ribossomal Database Project

RNAr Ácido ribonucléico ribossomal

SDF Sólidos dissolvidos fixos

SDS Sodium dodecyl sulfate (Dodecil sulfato de sódio)

SDT Sólidos dissolvidos totais

SDV Sólidos dissolvidos voláteis

SF-RL1 Amostra da biomassa do separador de fases do reator $\mathrm{R}_{\mathrm{L} 1}$

SF-RS1 Amostra da biomassa do separador de fases do reator $\mathrm{R}_{\mathrm{S} 1}$

SPC Sulfofenil carboxilato

SSF Sólidos suspensos fixos

SST Sólidos suspensos totais

SSV Sólidos suspensos voláteis

ST Sólidos totais

STF Sólidos totais fixos 
xxiv

STV Sólidos totais voláteis

TDH Tempo de detenção hidráulico

UASB Upflow anaerobic sludge blanket (Reator anaeróbio de fluxo ascendente e manta de lodo)

UFSCar Universidade Federal de São Carlos

UPGMA Unweighted pair group method with arithmetic averages

USP Universidade de São Paulo

UTO Unidade taxonômica organizacional

UV Ultra violeta 


\section{LISTA DE SÍMBOLOS}

$\begin{array}{ll}{ }^{\circ} \mathrm{C} & \text { Graus Celsius } \\ 1 / \mathrm{n} & \text { Ordem de potência relacionada ao mecanismo de adsorção } \\ \mathrm{A} 1 & \text { Valor inicial } \\ \mathrm{A} 2 & \text { Valor final } \\ \mathrm{C} & \text { Concentração de equilíbrio da solução } \\ \mathrm{C}_{10-14} & \text { Homólogos de LAS com } 10 \text { a } 14 \text { carbonos na cadeia alquílica } \\ \mathrm{d} & \text { Dia } \\ \mathrm{dx} & \text { Elongação da curva } \\ \mathrm{g} & \text { Grama } \\ \mathrm{h} & \text { Hora } \\ \mathrm{IC} & \text { 50\% da concentração máxima de inibição } \\ \mathrm{K}_{\mathrm{f}} & \text { Coeficiente de adsorção } \\ \mathrm{kg} & \text { Quilograma } \\ \mathrm{L} & \text { Litro } \\ \mathrm{m} & \text { Metro } \\ \mathrm{M} & \text { Molar } \\ \mathrm{mg} & \text { Miligrama } \\ \mathrm{mL} & \text { Mililitro } \\ \mu \mathrm{L} & \text { Microlitro } \\ \mathrm{mM} & \text { Milimolar } \\ \mu \mathrm{m} & \text { Micrômetro } \\ \mathrm{mmol} & \text { Milimol } \\ \mathrm{mV} & \text { Milivolt } \\ \mathrm{ng} & \text { Nanograma } \\ \mathrm{p} & \text { Nível de significância } \\ \mathrm{pmol} & \text { Picomol } \\ \mathrm{R}^{2} & \text { Coeficiente de determinação } \\ \mathrm{rpm} & \text { Rotações por minuto } \\ \mathrm{S} & \text { Concentração de LAS adsorvida por fase sólida } \\ \mathrm{U} & \text { Unidade } \\ \mathrm{x} 0 & \text { Centro } \\ \end{array}$




\section{SUMÁRIO}

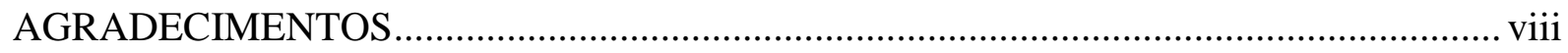

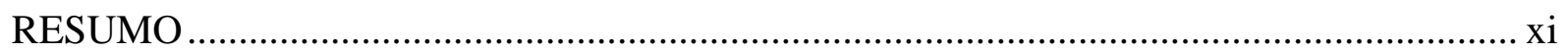

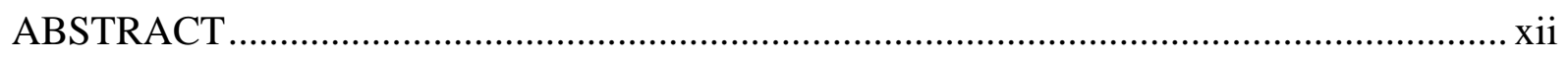

LISTA DE FIGURAS ............................................................................................ xiii

LISTA DE TABELAS ….........................................................................................

LISTA DE ABREVIATURAS E SIGLAS …....................................................................

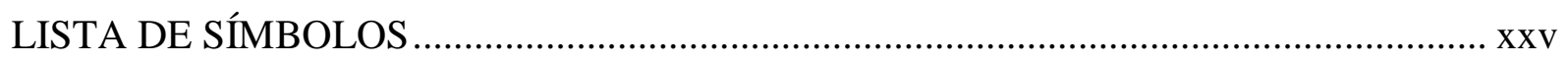

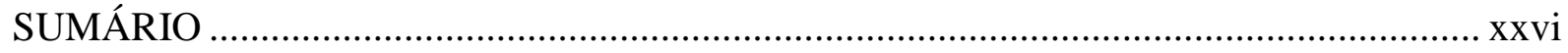

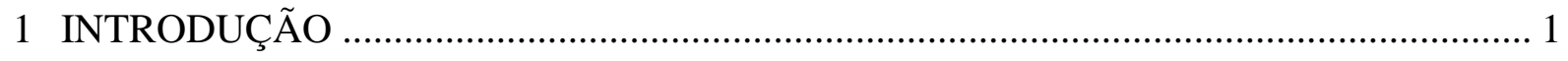

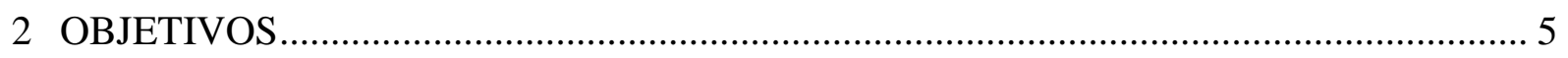

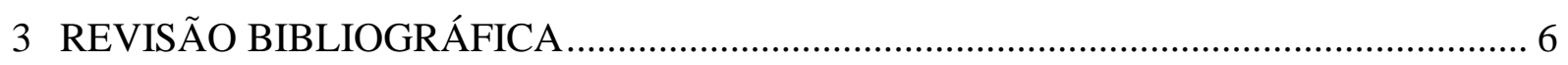

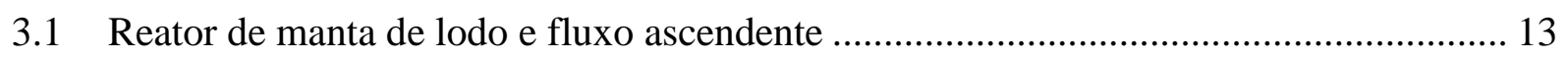

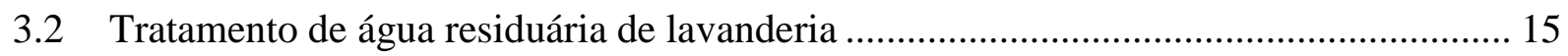

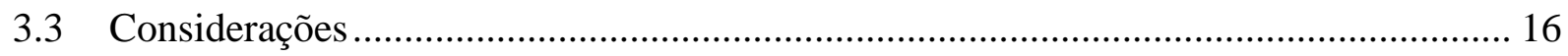

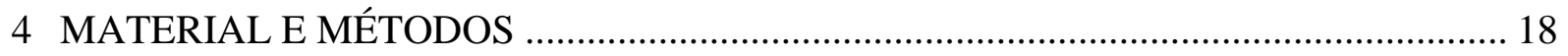

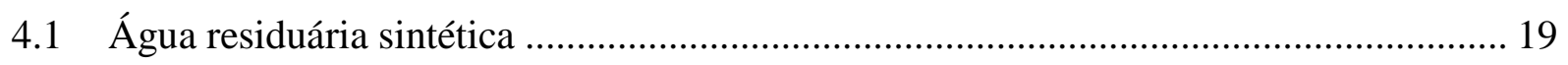

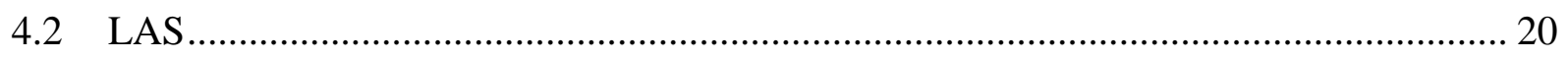

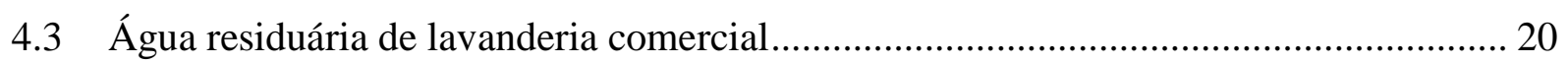

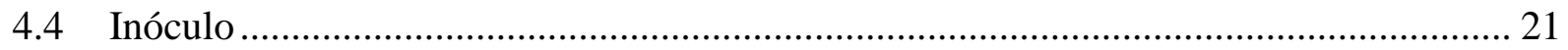

4.5 Determinação de isoterma de adsorção de LAS ....................................................... 22

4.6 Degradação de LAS com diferentes co-substratos .................................................. 23

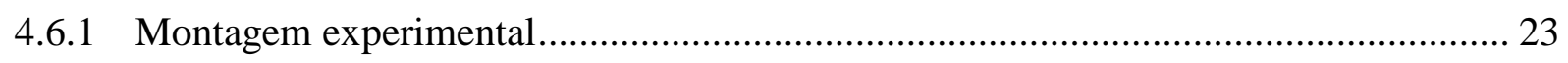

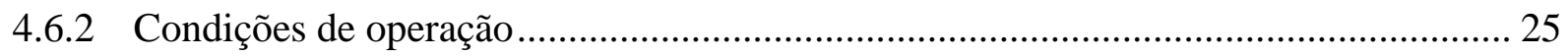


4.7 Avaliação da influência da biodisponibilidade de LAS, TDH e concentração de cosubstratos 28

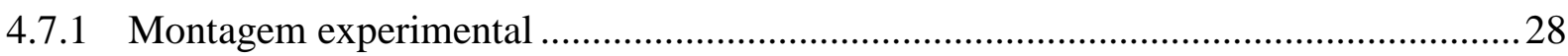

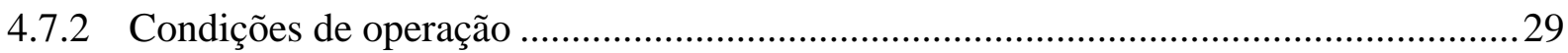

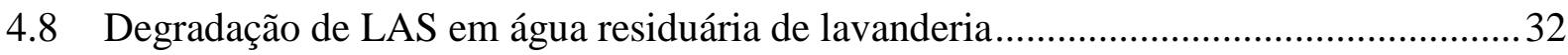

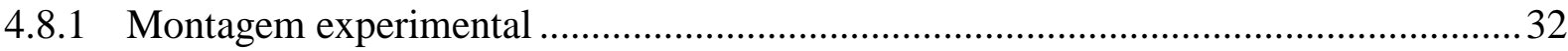

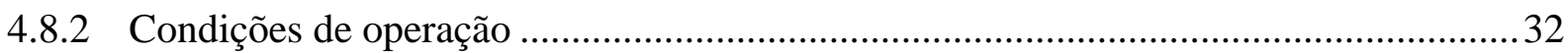

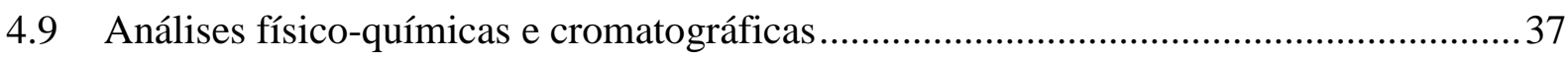

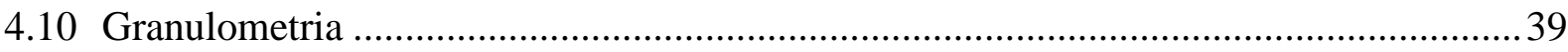

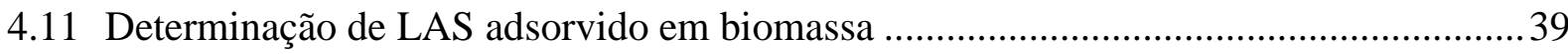

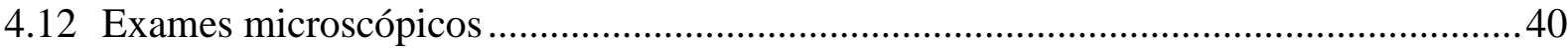

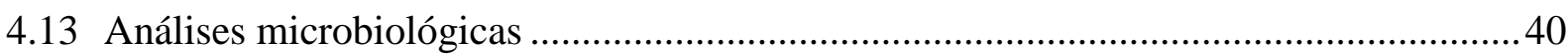

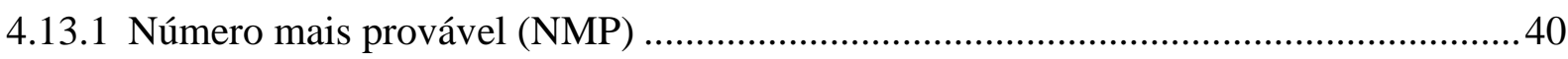

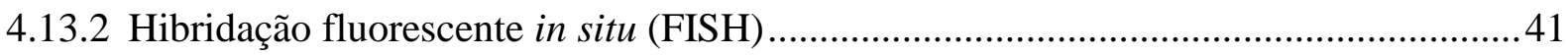

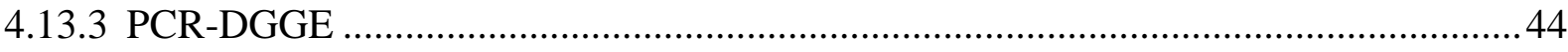

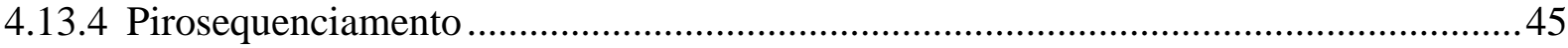

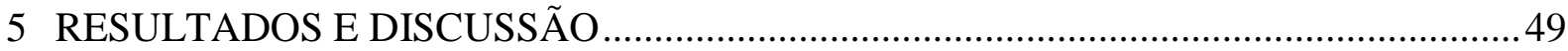

5.1 Determinação de isoterma de adsorção de LAS ......................................................... 49

5.2 Degradação de LAS em reator UASB com diferentes co-substratos.............................51

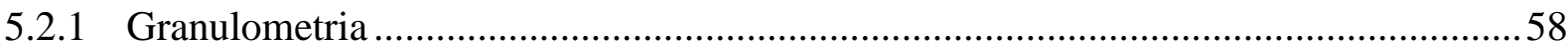

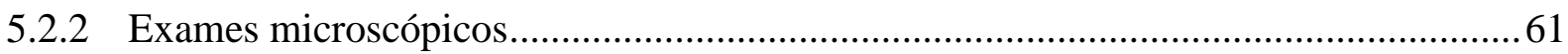

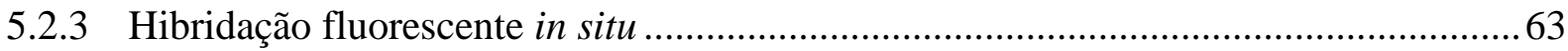

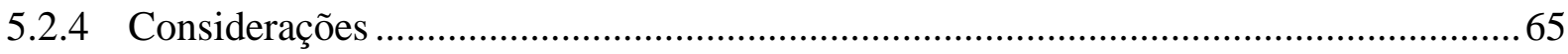

5.3 Avaliação da influência da biodisponibilidade de LAS, TDH e concentração de cosubstratos 67 
xxviii

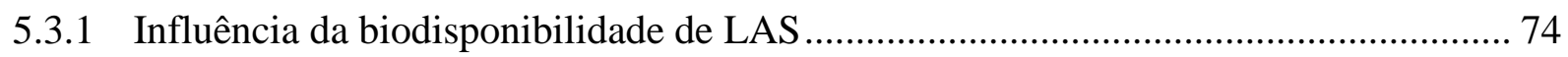

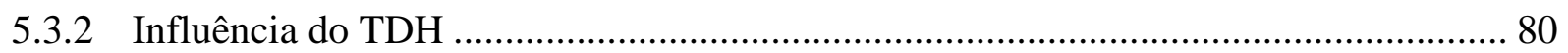

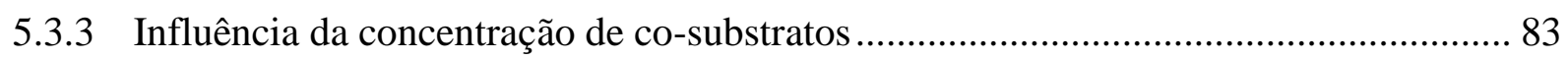

5.3.4 Interação entre biodisponibilidade de LAS, TDH e concentração de co-substratos na

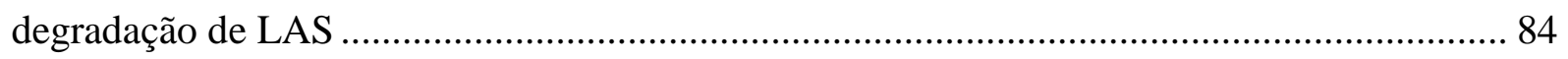

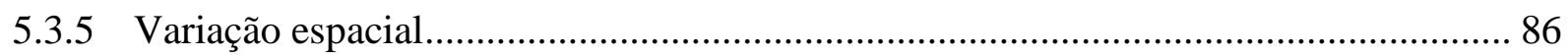

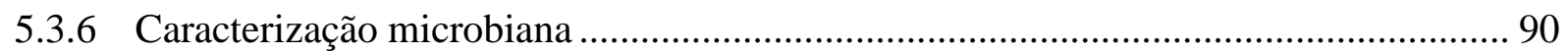

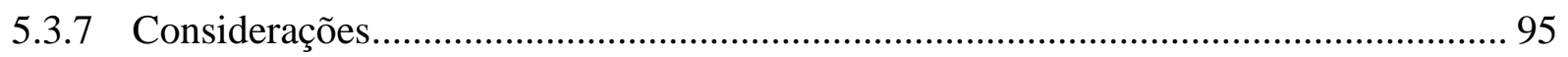

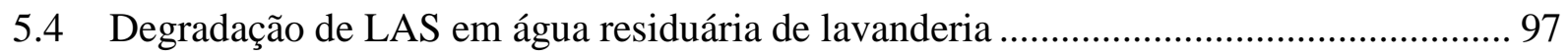

5.4.1 Caracterização da água de lavanderia comercial..................................................... 97

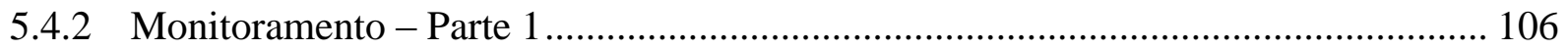

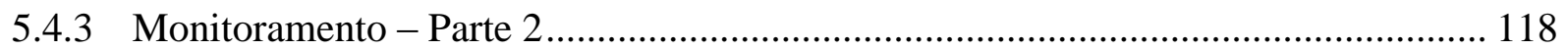

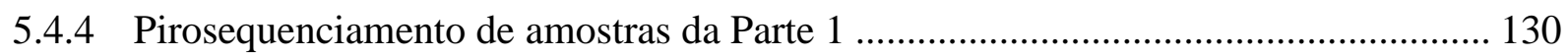

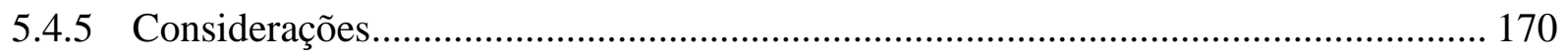

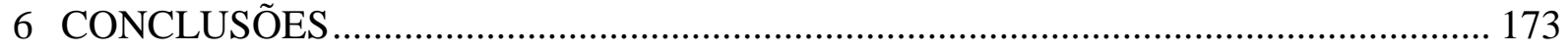

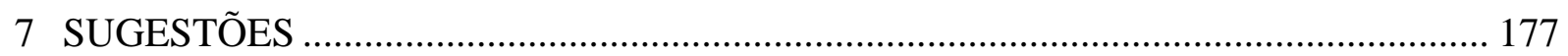

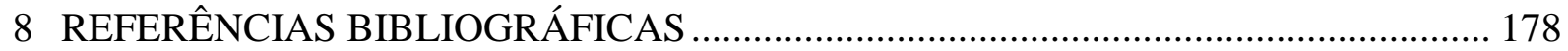

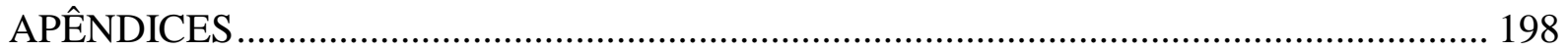




\section{INTRODUÇÃO}

O alquilbenzeno linear sulfonado (LAS) é um surfactante aniônico (de carga negativa) usado em produtos de limpeza. Dessa forma, LAS é encontrado em águas residuárias industriais e esgoto doméstico. Em estação de tratamento de esgoto (ETE) sua concentração pode variar de 1 a 25 mg/L (MORITA e SANTANA, 2005; MUNGRAY e KUMAR, 2009a). No esgoto bruto da ETE Barueri (SP), Morita e Santana (2005) observaram concentração média de $14 \pm 6 \mathrm{mg} / \mathrm{L}$ de surfactantes aniônicos.

O despejo do LAS em meio aquático pode aumentar a dispersão de poluentes pela formação de espumas e inibição dos microrganismos responsáveis pelos processos de depuração natural. Estudos reportaram a recalcitrância anaeróbia desse surfactante, devido à sua presença em lodos de tratamento de água residuária, solos e em sedimentos de água doce e ambiente marinho (JENSEN, 1999; LARA-MARTIN et al., 2006; LARA-MARTIN et al., 2010a). Apesar da recalcitrância anaeróbia do LAS, a aplicação de sistemas anaeróbios no tratamento de águas residuárias tem como vantagens, principalmente, as menores áreas para instalações, reduzido gasto de energia e menor geração de lodos. Além disso, ressalta-se a importância da degradação biológica em condição anaeróbia, considerando a possibilidade de acúmulo de surfactante nos diversos ambientes citados anteriormente.

Devido à presença de LAS em águas residuárias, diversos estudos foram realizados para avaliar sua remoção biológica em reatores anaeróbios: horizontal de leito fixo (DUARTE et al., 2008; OLIVEIRA et al., 2009); leito fluidificado (OLIVEIRA et al., 2010); batelada sequencial (DUARTE et al., 2010a); tanque agitado contínuo (continuous stirred-tank reactor 
- CSTR) (HAGGENSEN et al., 2002); leito granular expandido (expanded granular sludge bed - EGSB) (DELFORNO et al., 2012); e de manta de lodo e fluxo ascendente (upflow anaerobic sludge blanket - UASB) (ALMENDARIZ et al., 2001; MOGENSEN et al., 2003; SANZ et al., 2003; LOBNER et al., 2005).

Dentre essas configurações, o reator UASB foi o mais aplicado no tratamento desse composto, além de ser utilizado no tratamento anaeróbio de esgoto sanitário. No reator UASB foram observadas eficiências de degradação entre 13 e 85\%, aplicando concentração de LAS entre 5 e 50 mg/L, e tempo de detenção hidráulico (TDH) entre 6 e 48 h. O TDH usual foi entre 24-48 h, em virtude da recalcitrância do LAS, porém, em nenhum estudo foi definido o valor mais adequado para a degradação do surfactante (ALMENDARIZ et al., 2001; MOGENSEN e AHRING, 2002; MOGENSEN et al., 2003; SANZ et al., 2003).

A água residuária de lavanderia é um efluente com altas concentrações de surfactante aniônico (atingindo até $1.024 \mathrm{mg} / \mathrm{L}$ ) (SEO et al., 2001; BRAGA e VARESCHE, 2011), contribuindo de forma significativa para sua presença em ETE. Todavia, foram encontrados poucos estudos relacionados com a remoção biológica de surfactante em água residuária de lavanderia.

Em relação à degradação de LAS, foi avaliada a influência da estabilidade do processo anaeróbio. Lobner et al. (2005), observaram decréscimo da remoção de LAS após redução de temperatura (de $55^{\circ} \mathrm{C}$ para $32^{\circ} \mathrm{C}$ ), além de menor remoção de surfactante para concentração de ácidos orgânicos voláteis maior que 50 mg HAc/L.

Outro aspecto importante em relação à degradação de LAS refere-se à necessidade de suplementação de co-substratos - fontes de nitrogênio e carbono - em consórcios microbianos anaeróbios facultativos (KHLEIFAT, 2006a; ABBOUD et al., 2007). Nesse aspecto, ressalta-se também a quantidade em que esses co-substratos são fornecidos, ou seja, em excesso podem aumentar a concentração de ácidos voláteis, resultando em menor remoção de LAS (LOBNER et al., 2005). Por outro lado, observou-se aumento da remoção de surfactante devido à retirada de co- 
substratos, em reatores UASB (SANZ et al., 2003) e de batelada sequencial (DUARTE et al., 2010a).

Em virtude da influência de processos físicos, principalmente a adsorção, foi verificado em alguns estudos a dificuldade de degradação anaeróbia devido à falta de LAS biodisponível (parcela de surfactante disponível para uso no metabolismo de microrganismos) (HAGGENSEN et al., 2002; MOGENSEN et al., 2003). Nesse caso, os referidos autores observaram aumento da remoção de LAS de 20 para 25-28\% com o decréscimo da concentração de sólidos totais (ST) (de 20 para 11 g ST/L), em reator CSTR aplicando 100 $\mathrm{mg} / \mathrm{L}$ de LAS.

O objetivo do presente estudo foi avaliar a degradação de LAS em água residuária de lavanderia, devido à contribuição significativa (supracitada) dessa água residuária para a presença de surfactante em ETE. Considerando a influência da diversidade e concentração de cosubstratos, biodisponiblidade de LAS e do TDH na degradação de LAS, foi proposta a otimização desses parâmetros em água residuária sintética para posterior aplicação em água residuária de lavanderia. Dessa forma, foram avaliados os seguintes aspectos relativos à degradação de LAS em água residuária sintética: ( ) influência da diversidade de co-substratos suplementados; (ii) influência da biodisponibilidade de LAS, variando a concentração de biomassa; (iii) variação de TDH; (iv) influência da concentração de co-substratos. Ao final, realizou-se ensaio com água residuária de lavanderia, aplicando os parâmetros de otimização de degradação de LAS aplicáveis para reator em escala de bancada. No presente estudo empregou-se o reator UASB para avaliar a degradação de LAS, em virtude da aplicação dessa configuração em ETE, além do seu uso em estudos com LAS.

Ao longo do estudo, técnicas de biologia molecular foram aplicadas para avaliar: $(a)$ influência dos co-substratos e aeração da água residuária nas comunidades do domínio Archaea e Bacteria, mediante análise de hibridação fluorescente in situ (FISH); (b) influência 
da variação da biodisponibilidade de LAS, TDH e concentração de co-substratos nas comunidades do domínio Archaea e Bacteria, por meio da técnica de PCR-DGGE (polymerase chain reaction - denaturing gradient gel electrophoresis); (c) a diversidade filogenética do reator alimentado com água residuária de lavanderia, mediante análise de pirosequenciamento da região V3 do RNAr 16S. 


\section{OBJETIVOS}

O principal objetivo desse trabalho foi avaliar a eficiência de degradação de LAS em reator UASB. Para atingir esse objetivo foram avaliados:

- Capacidade de adsorção de LAS em lodo granulado;

- Eficiência de remoção de LAS em reator UASB com diferentes co-substratos;

- Comportamento do reator UASB alimentado com LAS após aeração na água residuária e efeitos na comunidade microbiana;

- Influência da biodisponibilidade de LAS na sua degradação;

- Efeito da variação de tempo de detenção hidráulico (TDH) na degradação de LAS;

- Influência da concentração de co-substratos na degradação de LAS;

- Efeito da variação de biodisponibilidade de LAS, TDH e concentração de cosubstratos na comunidade microbiana;

- Degradação de LAS em reator UASB alimentado com água residuária de lavanderia e caracterização filogenética da comunidade microbiana. 


\section{REVISÃO BIBLIOGRÁFICA}

Surfactantes são substâncias que possuem propriedades de limpeza, em virtude da capacidade de redução da tensão superficial da água por esses componentes. Surfactantes apresentam em sua composição uma parte hidrofóbica, que fica voltada para o ar, e uma parte hidrofílica, direcionada para a solução. A tensão superficial é reduzida devido a disposição entre as partes hidrofóbica e hidrofílica de surfactantes. O aumento da concentração de surfactantes resulta na formação de micelas. Após atingir a concentração micelar crítica (CMC: quantidade necessária de surfactante para formar micelas) a tensão superficial cessa sua redução e permanece constante. As propriedades de limpeza dos surfactantes devem-se à formação de micelas (BORSATO et al., 1999).

O LAS comercial constitui-se de uma mistura de homólogos, de acordo com o comprimento da cadeia alquílica, e de isômeros, em função da posição do anel aromático sulfonado na cadeia alquílica. A cadeia alquílica pode ter de 10 a 14 carbonos, e o anel aromático liga-se à cadeia linear alquílica em qualquer posição, exceto nos carbonos terminais (Figura 3.1). O anel aromático sulfonado corresponde à parte hidrofílica e a cadeia alquílica à parte hidrofóbica. 


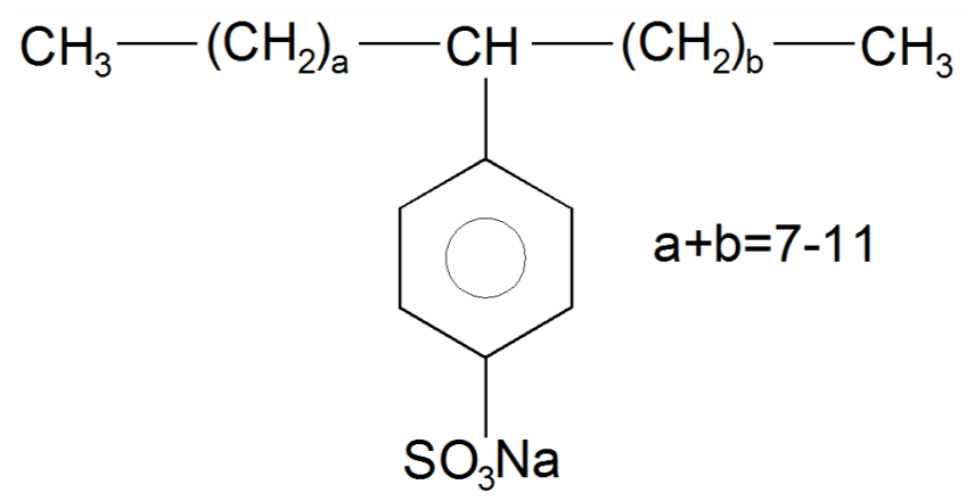

Figura 3.1: Molécula de LAS

Em condição aeróbia sabe-se que a rota de degradação de LAS envolve reações de $\beta$ e $\omega$-oxidação da cadeia alquílica, formando sulfofenil carboxilatos (SPC), seguida da quebra do anel aromático e dessulfonação (SCHÖRBERL, 1989). Denger e Cook (1999) observaram a possibilidade de dessulfonação de LAS em condição anóxica, em virtude da biotransformação de LAS em cultura anóxica tendo o surfactante como única fonte de enxofre. Lara-Martín et al. (2010b) propuseram rota de degradação para sedimento anóxico marinho, composta da transformação de LAS em SPC, seguida de sucessivas reações de $\beta$-oxidação. Outros estudos apontaram como possíveis intermediários da degradação anaeróbia: ácido benzeno sulfônico, benzaldeído, tolueno e benzeno (MOGENSEN e AHRING, 2002; DUARTE et al., 2008).

Estudos avaliaram a inibição das atividades metanogênica e acidogênica pela presença de LAS, sendo obtidos valores de $\operatorname{IC}_{50}(50 \%$ da concentração máxima de inibição) entre 3 e $59 \mathrm{mg} / \mathrm{L}$ de LAS (Tabela 3.1). De acordo com a Tabela 3.1, a presença de LAS em concentração até $10 \mathrm{mg} / \mathrm{L}$ foi capaz de inibir 50\% da atividade metanogênica, com exceção do estudo de Madsen e Rasmussen (1996). Nesse caso, os autores observaram inibição de 50\% da atividade acidogênica a partir de 18,9 mg/L de LAS (Tabela 3.1). 
Tabela 3.1: Valores de inibição de 50\% da atividade anaeróbia $\left(\mathrm{IC}_{50}\right)$

\begin{tabular}{|c|c|c|c|}
\hline $\begin{array}{c}\mathrm{IC}_{50} \\
(\mathrm{mg} / \mathrm{L})\end{array}$ & $\begin{array}{c}\text { Concentração } \\
\text { avaliada } \\
(\mathrm{mg} / \mathrm{L})\end{array}$ & Condição & Referência \\
\hline 6,3 & $0-10$ & Metanogênica & Garcia-Morales et al.(2001) \\
\hline 18,9 & $0-50$ & Acidogênica & \\
\hline $3-23$ & $0-200($ LAS C $10-14)$ & Metanogênica & Garcia et al. (2006b) \\
\hline 8,22 & $0-160$ & $\begin{array}{l}\text { Consórcio microbiano } \\
\text { isolado de sedimento }\end{array}$ & Pineda-Flores et al. (2010) \\
\hline 59 & $0-400\left(\mathrm{LAS} \mathrm{C}_{12}\right)$ & Metanogênica & Madsen e Rasmussen (1996) \\
\hline $\begin{array}{l}14 \\
27\end{array}$ & $\begin{array}{l}\text { 0-545 (mistura de } \\
\text { homólogos) }\end{array}$ & $\begin{array}{l}\text { Consumidora de acetato } \\
\text { Consumidora de propionato }\end{array}$ & Mösche e Meyer (2002) \\
\hline
\end{tabular}

Garcia et al. (2006b) observaram completa inibição de microrganismos metanogênicos em concentração de homólogos $\mathrm{C}_{10}-\mathrm{C}_{12}$ acima de $100 \mathrm{mg} / \mathrm{L}$, enquanto, para os homólogos $\mathrm{C}_{13}-\mathrm{C}_{14}$ não foi observada inibição completa para até $200 \mathrm{mg} / \mathrm{L}$ de LAS. Atribuiu-se a menor inibição dos homólogos $\mathrm{C}_{13}-\mathrm{C}_{14}$ observada por Garcia et al. (2006b) ao tamanho da cadeia alquílica, maior que os homólogos $\mathrm{C}_{10^{-}} \mathrm{C}_{12}$, devido ao Princípio da Distância. Swisher (1987) denominou como Princípio da Distância, a degradação mais rápida de homólogos com maior distância entre o grupo sulfonado e o mais distante grupo terminal metil ao longo da cadeia alquílica.

Angelidaki et al. (2004) observaram maior inibição de microrganismos consumidores de propionato (100\% de inibição na presença de $50 \mathrm{mg} / \mathrm{L}$ de LAS) em relação às bactérias consumidoras de acetato, butirato, glicose e $\mathrm{H}_{2} / \mathrm{CO}_{2}$ (100\% de inibição em concentrações acima de $141 \mathrm{mg} / \mathrm{L}$ de LAS). Ressalta-se o valor da concentração de inibição (141 mg/L) para glicose, evidenciando menor inibição da atividade acidogênica para um substrato mais complexo.

Em relação à toxicidade dos intermediários da degradação de LAS, Kimerle e Swisher (1977) verificaram potencial de toxicidade de SPCs menor que o de LAS: o valor LC50 (50\% da concentração letal) de SPC foi de 120-240\% maior que o para LAS. Todavia, não foram 
observados efeitos estrogênicos, isto é, alterações nos receptores de estrogênio, na presença de LAS e SPCs (NAVAS et al., 1999). Em peixes, foi verificada a dependência da toxicidade de LAS com a dureza da água (TOLLS et al., 2000): a dureza da água influencia o comportamento do LAS na fase aquosa e aumenta o potencial das superfícies negativamente carregadas, como membranas biológicas; como conseqüência, o aumento da dureza da água aumenta os gradientes de concentração de LAS nas guelras.

Lobner et al. (2005) ressaltaram a importância da estabilidade do processo anaeróbio na degradação de LAS. Empregando reator UASB em condição termofílica $\left(55^{\circ} \mathrm{C}\right)$, os autores observaram decréscimo da remoção de $\operatorname{LAS}^{1}$, acompanhados de alta concentração de ácidos voláteis (até $300 \mathrm{mg} \mathrm{HAc/L),} \mathrm{após} \mathrm{redução} \mathrm{da} \mathrm{temperatura} \mathrm{para} 32^{\circ} \mathrm{C}$. Além disso, os autores verificaram maior remoção de LAS (acima de $0,15 \mathrm{mg}$ LAS/g ST.d) para concentração de ácidos voláteis abaixo de $50 \mathrm{mg} \mathrm{HAc/L}$.

A degradação de LAS requer suplementação com fontes alternativas de carbono e nitrogênio para manter a atividade dos microrganismos. Abboud et al. (2007) observaram aumento da degradação de LAS (de 60\% para 100\%) com a adição de outras fontes de carbono e nitrogênio, em consórcio de bactérias anaeróbias facultativas. O consórcio era mantido em meio nutricional com 300 mg/L de LAS e, após 150 h de incubação observou-se apenas $60 \%$ de degradação. Verificou-se completa degradação de LAS com a adição de fontes alternativas de carbono e nitrogênio. As seguintes fontes de carbono foram avaliadas: glicose, sacarose, maltose, manitol e succinato. Como fontes de nitrogênio foram testadas: nitrato de amônio, cloreto de amônio, caseína, extrato de levedura e triptona. Duarte et al.(2008) observaram aumento da remoção de LAS (de $20 \%$ para $37 \%$ ) após adição de extrato de levedura, um co-substrato complexo, fonte de nitrogênio, micronutrientes e vitamina $B$, em reator anaeróbio horizontal de leito fixo (RAHLF).

\footnotetext{
${ }^{1}$ Remoção de LAS: considerando apenas concentração afluente e efluente de surfactante.
} 
Também se destaca a concentração de co-substratos, uma vez que altos valores podem aumentar a produção de ácidos voláteis no sistema anaeróbio, reduzindo a remoção de LAS (LOBNER et al., 2005). Verificou-se aumento da degradação de $\operatorname{LAS}^{2}$ (de 25-34\% para $53 \%$ ), após a retirada de co-substratos (extrato de levedura, amido e sacarose), em reator de bateladas sequenciais (DUARTE et al., 2010a). Além disso, observou-se aumento da degradação de $65 \%$ para $85 \%$, atribuído à retirada de co-substratos (acetato, propionato, butirato, lactato, metanol, etanol e sacarose), em reator UASB (SANZ et al., 2003). Todavia, esse aumento da degradação de LAS no estudo de Sanz et al. (2003) foi acompanhado de redução de $11,5 \%$ da biomassa do reator.

Em ensaios em batelada com lodos ativados, Rittmann et al. (2001) verificaram aumento da quantidade de LAS degradado para concentrações maiores de surfactante (concentração variando entre 0,1 e $20 \mathrm{mg} / \mathrm{L}$ ). Apesar da adaptação da comunidade microbiana ao LAS envolver acúmulo de espécies capazes de degradar o surfactante, os autores não verificaram aumento da biomassa proporcional à concentração de LAS na alimentação. Segundo os autores, uma possibilidade seria o uso de parcelas da matéria orgânica da alimentação no metabolismo dos microrganismos responsáveis pela degradação de LAS, resultando em aumento da biomassa em proporção menor que o aumento da concentração de LAS na alimentação.

Com exceção da linhagem RZLAS obtida por Denger e Cook (1999), não são conhecidas culturas puras capazes de degradar completamente o LAS. Em virtude da limitada capacidade metabólica de uma única espécie, estudos apontam para a necessidade de consórcios bacterianos na degradação de LAS (CSERHATI et al., 2002; KHLEIFAT, 2006a). Verificou-se degradação de LAS maior (eficiência de 70\%) em um consórcio bacteriano anaeróbio facultativo formado por Pantoea agglomerans e Serratia odorífera do que em

\footnotetext{
${ }^{2}$ Degradação de LAS: considerando surfactante adicionado, descartado no efluente e adsorvido na biomassa
} 
culturas isoladas (eficiências entre 25 e 30\%), aplicando concentração inicial de $200 \mathrm{mg} / \mathrm{L}$ de LAS (KHLEIFAT, 2006a; b).

Aplicando processos físico-químicos, foi avaliada a remoção de LAS por adsorção em carvão ativado em pó seguida de microfiltração (BASAR et al., 2004) e adsorção em resinas e carvão ativado (SCHOUTEN et al., 2007). Basar et al. (2004) verificaram remoção de LAS maior que $65 \%$ (concentração de LAS entre 68 e 3.400 mg/L), aplicando carvão ativado com área superficial de $465 \mathrm{~m}^{2} / \mathrm{g}$ e partículas de $30 \mu \mathrm{m}$, seguida de micro-filtração. Schouten et al. (2007) verificaram maior capacidade de adsorção (0,6-1,7 g LAS/g) em adsorventes de carga positiva, enquanto, resinas não-iônicas ou carvão ativado, resultaram em menor capacidade de adsorção (de 0,02 a 0,6 g LAS/g). Os autores concluíram que a carga elétrica da superfície dos adsorventes e o tamanho dos poros são importantes parâmetros para avaliar a adsorção de LAS. Meso (2-50 nm) ou macroporos (> $50 \mathrm{~nm}$ ) são preferíveis, devido à dificuldade das moléculas de LAS acessarem a superfície provida pelos microporos $(<2 \mathrm{~nm})$.

A adsorção está relacionada à biodisponibilidade, toxicidade e destino do LAS (KNAEBEL et al., 1996; TRAINA et al., 1996; WOLF e FEIJTEL, 1998). A adsorção pode ser atribuída a forças químicas ou físicas, dependendo das propriedades físico-químicas, natureza do material e parâmetros ambientais (YING, 2006). LAS pode adsorver diretamente na superfície de sólidos ou interagir com o adsorvente, sendo que o mecanismo de adsorção depende da natureza do adsorvente e a concentração do surfactante (ADEEL e LUTHY, 1995; OU et al., 1996; BROWNAWELL et al., 1997; FYTIANOS et al., 1998). A adsorção de LAS pode ser descrita por meio de isotermas de adsorção, sendo geralmente usadas as equações de Freundlich ou de Langmuir.

O tamanho da cadeia alquílica pode influenciar a adsorção de LAS, sendo observado aumento da adsorção em homólogos com maior cadeia alquílica (HAND e WILLIAMS, 1987; GARCIA et al., 2002). A adsorção de LAS a sedimentos e lodos atribui-se a interações 
hidrofóbicas (não polares), ou seja, conforme o comprimento da cadeia alquílica aumenta, a hidrofobicidade da molécula aumenta e a carga negativa do grupo sulfonado tem menor impacto nas interações hidrofóbicas (HAND e WILLIAMS, 1987; GARCIA et al., 2002).

Além disso, a maior presença de íons cálcio e magnésio podem aumentar a adsorção de LAS em virtude da redução da repulsão eletrostática entre as partes iônicas do surfactante e da adsorção direta em partículas do lodo (criando locais de carga positiva, no qual o surfactante, carregado negativamente, pode adsorver) (WESTALL et al., 1999; GARCIA et al., 2002).

Estudos verificaram ligeiro aumento da degradação de LAS com a redução da concentração de biomassa (HAGGENSEN et al., 2002; MOGENSEN et al., 2003). Mogensen et al. (2003) observaram aumento da degradação de LAS (de 20\% para 28\%) com a redução da biomassa de $20 \mathrm{~g} \mathrm{ST/L}$ para $11 \mathrm{~g} \mathrm{ST/L}$, em reator de tanque agitado semi contínuo (semi continuous stirred-tank reactor - semi CSTR). Haggensen et al. (2002) observaram também aumento da degradação de LAS (de $20 \%$ para 25\%) com a redução da biomassa de 20 g ST/L para $11 \mathrm{~g} \mathrm{ST/L}$, em reator de tanque agitado contínuo (CSTR). Os autores atribuíram o aumento da degradação de LAS ao aumento da biodisponibilidade de LAS (HAGGENSEN et al., 2002; MOGENSEN et al., 2003), em virtude da redução de sítios de adsorção causada pela menor concentração de biomassa. Biodisponibilidade pode ser definida como o potencial de organismos vivos de obter compostos químicos a partir do ambiente externo (abiótico), de modo que esses compostos químicos possam ser usados no seu metabolismo (ADRIANO, 2001). No caso da biodisponibilidade de LAS relacionada com a concentração de biomassa, questiona-se se realmente a adsorção de LAS na biomassa seria realmente um limitante à degradação na medida em que o contato do surfactante com os microrganismos poderia aumentar sua degradação. Todavia a formação de biofilmes envolve a presença e produção de polímeros extra-celulares, além da presença de material inerte no centro, no caso de biomassa 
na forma granulada (COSTERTON et al., 1995; DAVEY e O'TOOLE, 2000; ABBASI e ABBASI, 2012). Em biomassa na forma granulada, a parcela de polímeros extracelulares pode representar de 0,6 a $20 \%$ dos sólidos suspensos voláteis, enquanto, a parcela de matéria inorgânica pode corresponder de 10 a 90\% da massa seca (SCHMIDT e AHRING, 1996). Nesse aspecto, destaca-se também a importância de íons de cálcio na formação de grânulos, sendo constituinte de polisacarídeos e servindo como suportes inertes por meio da formação de precipitados (SCHMIDT e AHRING, 1996). Dessa forma, é possível que parte do LAS biodisponível seja reduzida pela adsorção nas parcelas inertes e de polímeros do biofilme, sendo, portanto, plausível relacionar a biodisponibilidade de LAS com a concentração de biomassa.

Outras formas de remoção de LAS envolvem o uso de processos oxidativos avançados na remoção de LAS (BELTRAN et al., 2000; WANG et al., 2008). Beltrán et al. (2000) verificaram remoção de LAS (concentração inicial de $15 \mathrm{mg} / \mathrm{L}$ ) entre 79-85\% em água residuária sintética e entre 39-47\% em esgoto sanitário; as menores eficiências em esgoto sanitário foram atribuídas à competição com a matéria orgânica presente pelo ozônio e radicais hidroxila dissolvidos. Wang et al. (2008) verificaram alta eficiência de remoção de LAS (99\%) em sistema combinando oxidação Fenton e processo biológico aeróbio, aplicando $490 \mathrm{mg} / \mathrm{L}$ de LAS.

\subsection{Reator de manta de lodo e fluxo ascendente}

Vários estudos empregaram o reator anaeróbio de manta de lodo e fluxo ascendente (upflow anaerobic sludge blanket - UASB) na degradação de LAS (Tabela 3.2). Nos estudos utilizando reatores UASB, a degradação de LAS variou de 13 a 85\%, em concentração inicial 
variando de $1 \mathrm{mg} / \mathrm{L}$ a $50 \mathrm{mg} / \mathrm{L}$. Observou-se que o meio mineral Angelidaki (1990) foi bastante utilizado. A maior parte dos estudos aplicou TDH entre 12 e $24 \mathrm{~h}$, sendo evitados valores baixos, devido à recalcitrância do surfactante.

Nesses casos, observou-se a preferência em aplicar concentrações de LAS abaixo de $20 \mathrm{mg} / \mathrm{L}$, em virtude do seu potencial de inibição (Tabela 3.2). Angelidaki et al. (2004) verificaram que para concentrações de LAS acima de $50 \mathrm{mg} / \mathrm{L}$ ocorreu inibição da maioria dos grupos microbianos do processo anaeróbio. Almendariz et al. (2001) observaram decréscimo da remoção de LAS (de $68 \%$ para 33\%) com o aumento da concentração de surfactante (de 20 para $50 \mathrm{mg} / \mathrm{L})$.

Atribuiu-se a menor eficiência de degradação de LAS (13\%) à redução de temperatura (para $32^{\circ} \mathrm{C}$ ) em reator UASB termofílico $\left(55^{\circ} \mathrm{C}\right)$, conforme discutido anteriormente (p. 7) (LOBNER et al., 2005).

Tabela 3.2: Aplicação do reator UASB no tratamento de águas residuárias contendo LAS

\begin{tabular}{|c|c|c|c|c|c|c|}
\hline $\begin{array}{c}\text { TDH } \\
\text { (h) }\end{array}$ & $\begin{array}{l}\text { Duração } \\
\text { (d) }\end{array}$ & $\begin{array}{c}\text { LAS } \\
(\mathrm{mg} / \mathrm{L})\end{array}$ & Afluente & Condição & $\begin{array}{c}\text { Degradação } \\
(\%)\end{array}$ & Referência \\
\hline 48 & $\begin{array}{l}242 \\
289\end{array}$ & 10 & $\begin{array}{l}\text { Meio mineral } \\
\text { (ANGELIDAKI } \\
\text { et al. }, 1990) \mathrm{e} \\
\text { glicose }\end{array}$ & $\begin{array}{l}\text { Mesofílica } \\
\left(37^{\circ} \mathrm{C}\right) \\
\text { Termofílica } \\
\left(55^{\circ} \mathrm{C}\right)\end{array}$ & $\begin{array}{l}13 \\
51\end{array}$ & $\begin{array}{l}\text { Lobner et al. } \\
\quad(2005)\end{array}$ \\
\hline 12 & 18 & 10 & $\begin{array}{l}\text { Meio mineral } \\
\text { (ANGELIDAKI } \\
\text { et al., 1990) }\end{array}$ & $\begin{array}{l}\text { Termofílica } \\
\left(55^{\circ} \mathrm{C}\right)\end{array}$ & 27 & $\begin{array}{c}\text { Mogensen et } \\
\text { al. (2003) }\end{array}$ \\
\hline 24 & $\begin{array}{l}100 \\
125\end{array}$ & $4-5$ & $\begin{array}{c}\text { Co-substratos }{ }^{1} \\
\text { Sem co-substratos }\end{array}$ & $\begin{array}{l}\text { Mesofílica } \\
\left(30^{\circ} \mathrm{C}\right)\end{array}$ & $\begin{array}{l}64 \\
85\end{array}$ & $\begin{array}{l}\text { Sanz et al. } \\
\quad(2003)\end{array}$ \\
\hline 12 & 19 & 1 & $\begin{array}{l}\text { Meio mineral } \\
\text { (ANGELIDAKI } \\
\text { et al., 1990) }\end{array}$ & $\begin{array}{c}\text { Termofílica } \\
\left(55^{\circ} \mathrm{C}\right)\end{array}$ & 40 & $\begin{array}{c}\text { Mogensen e } \\
\text { Ahring } \\
\text { (2002) }\end{array}$ \\
\hline $\begin{array}{c}6 \\
24\end{array}$ & 175 & $\begin{array}{l}20 \\
50\end{array}$ & $\begin{array}{c}\text { Meio mineral } \\
\text { (SHELTON e } \\
\text { TIEDJE, 1984) e } \\
\text { lactose }\end{array}$ & $\begin{array}{l}\text { Mesofílica } \\
\left(35^{\circ} \mathrm{C}\right)\end{array}$ & 41 & $\begin{array}{l}\text { Almendariz } \\
\text { et al. (2001) }\end{array}$ \\
\hline
\end{tabular}

${ }^{1}$ Acetato, propionato, butirato, lactato, metanol, etanol e sacarose. 
Além dos estudos citados na Tabela 3.2, em outros dois trabalhos foram avaliados o destino final de surfactantes aniônicos em reatores UASB, em ETE (MUNGRAY e KUMAR, 2008; 2009b). Nos dois estudos, não foi observada degradação significativa de surfactante nos reatores UASB, operados com TDH em torno de $10 \mathrm{~h}$ e concentração de surfactante aniônico em torno de $6 \mathrm{mg} / \mathrm{L}$.

\subsection{Tratamento de água residuária de lavanderia}

A água residuária de lavanderia é um efluente caracterizado pela alta concentração de LAS. Na caracterização de água residuária de lavanderia doméstica, Seo et al. (2001) verificaram valores de surfactante aniônico entre 62 e 674 mg/L, além de DQO variando entre 488 e 2847 mg/L e SST entre 38 e 857 mg/L. Na caracterização de água residuária de lavanderia comercial, Braga e Varesche (2011) observaram concentração de LAS entre 12 e $1.024 \mathrm{mg} / \mathrm{L}, \mathrm{DQO}$ entre 620 e $4.800 \mathrm{mg} / \mathrm{L}$ e SST entre 10 e $290 \mathrm{mg} / \mathrm{L}$.

Todavia, são poucos os estudos de tratamento biológico de água residuária de lavanderia. Em condição similar (alta concentração de surfactante), Hosseini e Borghei (2005) observaram a degradação de mistura de LAS e ABS (alquilbenzeno sulfonado não linear), com eficiências entre 78 e $87 \%$, em sistema de lodos ativados usado para tratamento de efluente de indústria de detergentes. Nesse estudo foi aplicada concentração de surfactantes entre 15 e $400 \mathrm{mg} / \mathrm{L}$, não sendo possível o tratamento biológico em concentração de surfactante acima de $500 \mathrm{mg} / \mathrm{L}$.

Em relação aos estudos direcionados para o tratamento de efluente de lavanderia, na maioria deles foram aplicados tratamentos físico-químicos, como processos oxidativos avançados, ultrafiltração, osmose reversa, adsorção em carvão ativado, 
precipitação/coagulação, eletroflotação e eletrocoagulação (PERKOWSKI et al., 2000; SEO et al., 2001; ŠOSTAR-TURK et al., 2005; SCHOUTEN et al., 2007; CIABATTIA et al., 2009; WANG et al., 2009).

\subsection{Considerações}

Foram relatados valores de inibição de $50 \%$ da atividade $\left(\mathrm{IC}_{50}\right)$ em concentração de LAS entre 3 e $59 \mathrm{mg} / \mathrm{L}$, sendo verificada completa inibição em concentrações de surfactante acima de $50 \mathrm{mg} / \mathrm{L}$. Dessa forma, não se recomenda a aplicação de LAS em concentração acima de 50 mg/L em sistema anaeróbio, em virtude do potencial de inibição dos processos.

A influência da biodisponibilidade de LAS foi verificada com o aumento da degradação de LAS, de 20\% para 25-28\% após decréscimo da concentração de biomassa, de 20 g ST/L para 11 g ST/L. Portanto, pressupõe-se maior degradação de LAS em menor concentração de biomassa.

A necessidade de adição de fontes de nitrogênio e carbono para a degradação de LAS foi verificada em vários estudos. Todavia, a concentração desses co-substratos pode influenciar a degradação do surfactante: altas concentrações podem aumentar a produção de ácidos voláteis e prejudicar a degradação, enquanto, a retirada de co-substratos pode provocar aumento da degradação de surfactante.

Entre os reatores UASB aplicados no tratamento de água residuária contendo LAS, observou-se eficiência de degradação entre 13 e 85\%. Nos reatores UASB avaliados, foram aplicados TDH entre 6 e 48 h, sendo mais frequente valores entre 12 e $24 \mathrm{~h}$ em virtude da recalcitrância do LAS. 
Foi relatada alta concentração de surfactantes na água residuária de lavanderia (entre 12 e $1.024 \mathrm{mg} / \mathrm{L})$, contribuindo para a presença de surfactantes em esgoto doméstico. Em virtude da alta concentração de surfactantes na água residuária de lavanderia, verificou-se maior uso de tratamentos físico-químicos. Apesar da susceptibilidade de choques tóxicos em sistemas biológicos, o estudo da biodegradabilidade de água residuária de lavanderia pode resultar em sistemas que combinem eficientemente tratamento biológico e físico-químico. 


\section{MATERIAL E MÉTODOS}

O estudo consistiu da avaliação da degradação de LAS em reator UASB, inicialmente em água residuária (AR) sintética e, ao final, em água residuária (AR) de lavanderia. A Figura 4.1 apresenta o fluxograma experimental.

\begin{tabular}{|c|c|c|}
\hline Ensaio & Condições experimentais & Análises \\
\hline $\begin{array}{l}\text { Isoterma de } \\
\text { adsorção }\end{array}$ & $\begin{array}{l}\text { >AR sintética+LAS }(5-45 \mathrm{mg} / \mathrm{L})+\text { Inóculo } \\
\text { esterilizado em autoclave } \\
>\text { Agitação } 150 \mathrm{rmm}-\text { Temp. } 30^{\circ} \mathrm{C}-24 \mathrm{~h}\end{array}$ & $\begin{array}{l}\text { - LAS } \\
\text { - Sólidos totais }\end{array}$ \\
\hline $\begin{array}{l}\text { Degradação de } \\
\text { LAS com } \\
\text { diferentes co- } \\
\text { substratos }\end{array}$ & $\begin{array}{l}\text { Reator UASB }(10,5 \mathrm{~L}) \\
\text { o TDH } 24 \mathrm{~h} \text { - Temp. } 30^{\circ} \mathrm{C} \\
\text { AR sintética + LAS }(14 \mathrm{mg} / \mathrm{L}) \\
\text { - Etapas: } \\
\text { I. Adaptação (etanol; sem LAS) - } 30 \mathrm{~d} \\
\text { II. Adição de LAS (metanol, etanol e LAS) - } 140 \mathrm{~d} \\
\text { III. Recirculação de efluente - } 26 \mathrm{~d} \\
\text { IV. Aeração da AR e recuperação - } 51 \mathrm{~d} \\
\text { V. Adição de extrato de levedura (metanol, etanol, } \\
\text { extrato de levedura e LAS) - } 44 \mathrm{~d}\end{array}$ & $\begin{array}{l}\text { - LAS } \\
\text { - DQO } \\
\text { - pH } \\
\text { - Alcalinidade } \\
\text { - Ácidos voláteis } \\
\text { - Granulometria } \\
\text { - Sólidos } \\
\text { - Sulfato e Sulfeto } \\
\text { - FISH } \\
\text { - NMP }\end{array}$ \\
\hline $\begin{array}{l}\text { Avaliação da } \\
\text { influência da } \\
\text { biodisponibilidade } \\
\text { de LAS, TDH e } \\
\text { concentração de } \\
\text { co-substratos }\end{array}$ & 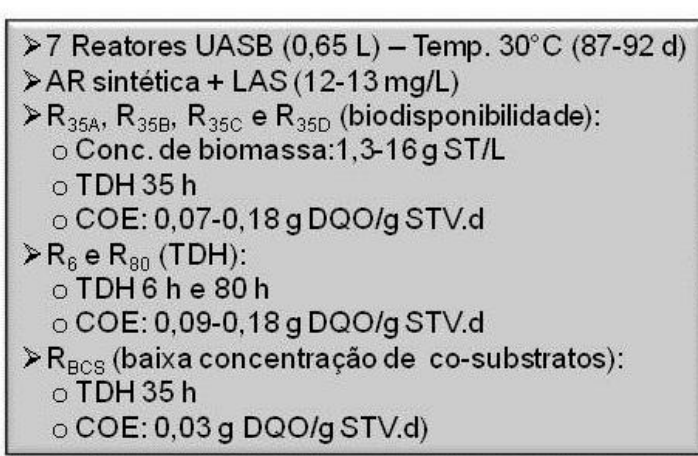 & $\begin{array}{l}\text { - LAS } \\
\text { - DQO } \\
\text { - pH } \\
\text { - Alcalinidade } \\
\text { - Ácidos voláteis } \\
\text { - Sólidos } \\
\text { - Variação espacial } \\
\text { (Ácid.voláteis e LAS) } \\
\text { - PCR-DGGE }\end{array}$ \\
\hline $\begin{array}{l}\text { Degradação de } \\
\text { LAS em água } \\
\text { residuária de } \\
\text { lavanderia }\end{array}$ & 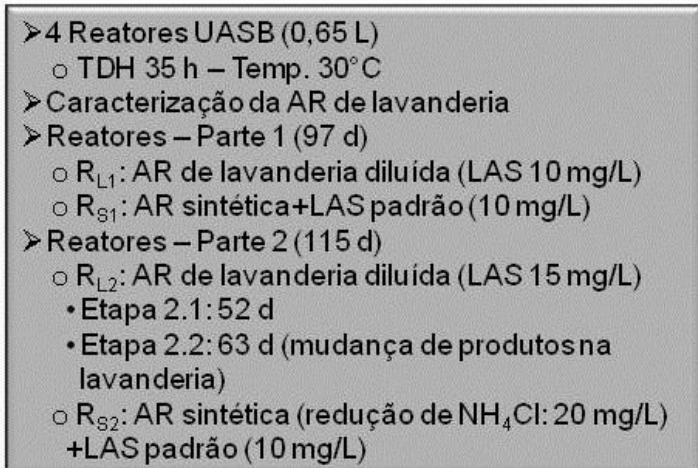 & $\begin{array}{l}\text { - LAS } \\
\text { - DQO } \\
\text { - pH } \\
\text { - Alcalinidade } \\
\text { - Ácidos voláteis } \\
\text { - Granulometria } \\
\text { - Sólidos } \\
\text { - Sulfato } \\
\text { - Sulfeto } \\
\text { - Variação espacial } \\
\text { (Ácid. voláteis e LAS) } \\
\text { - Pirosequenciamento } \\
\text { (Reatores Parte 1) }\end{array}$ \\
\hline
\end{tabular}

Figura 4.1: Fluxograma experimental 


\section{1 Água residuária sintética}

A alimentação usada nos ensaios consistiu de meio mineral (concentração de $\mathrm{MgCl}_{2} \cdot 6 \mathrm{H}_{2} \mathrm{O}$ modificada para $25 \mathrm{mg} / \mathrm{L}$, Tabela 4.1) (ANGELIDAKI et al., 1990), solução de vitaminas (Tabela 4.2) (TOUZEL e ALBAGNAC, 1983) e co-substratos (metanol, etanol e extrato de levedura - as concentrações variaram em cada ensaio). Modificou-se a concentração de $\mathrm{MgCl}_{2} \cdot 6 \mathrm{H}_{2} \mathrm{O}$ do meio mineral para reduzir a concentração de íons $\mathrm{Mg}^{2+}$, devido à sua capacidade de aumentar a adsorção de LAS (GARCIA et al., 2002).

\begin{tabular}{|c|c|}
\hline Componentes & $\begin{array}{l}\text { Quantidades }-1.000 \mathrm{~mL} \\
\text { de água de abastecimento }\end{array}$ \\
\hline $\mathrm{NH}_{4} \mathrm{Cl}$ & $1.000 \mathrm{mg}$ \\
\hline $\mathrm{NaCl}$ & $100 \mathrm{mg}$ \\
\hline $\mathrm{MgCl}_{2} \cdot 6 \mathrm{H}_{2} \mathrm{O}^{*}$ & $25 \mathrm{mg}$ \\
\hline $\mathrm{CaCl}_{2} \cdot 2 \mathrm{H}_{2} \mathrm{O}$ & $50 \mathrm{mg}$ \\
\hline $\mathrm{K}_{2} \mathrm{HPO} 4.3 \mathrm{H}_{2} \mathrm{O}$ & $400 \mathrm{mg}$ \\
\hline $\mathrm{FeCl}_{2} \cdot 4 \mathrm{H}_{2} \mathrm{O}$ & $2 \mathrm{mg}$ \\
\hline $\mathrm{H}_{3} \mathrm{BO}_{3}$ & $0,05 \mathrm{mg}$ \\
\hline $\mathrm{ZnCl}_{2}$ & $0,05 \mathrm{mg}$ \\
\hline $\mathrm{CuCl}_{2} \cdot 2 \mathrm{H}_{2} \mathrm{O}$ & $0,038 \mathrm{mg}$ \\
\hline $\mathrm{MnCl}_{2} \cdot 4 \mathrm{H}_{2} \mathrm{O}$ & $0,05 \mathrm{mg}$ \\
\hline$\left(\mathrm{NH}_{4}\right)_{6} \mathrm{Mo}_{7} \mathrm{O}_{24} \cdot 4 \mathrm{H}_{2} \mathrm{O}$ & $0,05 \mathrm{mg}$ \\
\hline $\mathrm{AlCl}_{3}$ & $0,05 \mathrm{mg}$ \\
\hline $\mathrm{CoCl}_{2} \cdot 6 \mathrm{H}_{2} \mathrm{O}$ & $0,05 \mathrm{mg}$ \\
\hline $\mathrm{NiCl}_{2} \cdot 6 \mathrm{H}_{2} \mathrm{O}$ & $0,092 \mathrm{mg}$ \\
\hline EDTA & $0,5 \mathrm{mg}$ \\
\hline $\mathrm{HCl}$ concentrado & $1 \mu \mathrm{L} / \mathrm{L}$ \\
\hline $\mathrm{Na}_{2} \mathrm{SeO}_{3} .5 \mathrm{H}_{2} \mathrm{O}$ & $0,1 \mathrm{mg}$ \\
\hline
\end{tabular}


Tabela 4.2: Solução de vitaminas

\begin{tabular}{lc}
\hline Componentes & $\begin{array}{c}\text { Quantidades }-1.000 \mathrm{~mL} \\
\text { de água de abastecimento }(\mathrm{mg})\end{array}$ \\
\hline Biotina & 0,020 \\
Ácido fólico & 0,020 \\
Tiamina & 0,050 \\
Riboflavina & 0,050 \\
Ácido Nicotínico & 0,050 \\
Pantotenato de cálcio & 0,050 \\
Piridoxina & 0,100 \\
Vitamina B12 & 0,001 \\
Ácido Lipóico & 0,050 \\
Ácido p-aminobenzóico & 0,050 \\
\hline
\end{tabular}

Fonte: Touzel e Albagnac (1983)

\subsection{LAS}

Utilizou-se neste estudo LAS comercial, dodecilbenzeno sulfonado de sódio (Aldrich), grau técnico, com peso molecular de 348,48 g/mol e homólogos $\mathrm{C}_{10}-\mathrm{C}_{13}$.

\section{3 Água residuária de lavanderia comercial}

Uma lavanderia comercial situada em São Carlos-SP permitiu a coleta do descarte de máquinas lavadora de roupas. Coletou-se a água residuária da lavagem de roupas coloridas, cujos principais insumos usados no processo de lavagem eram detergentes em pó comercial (lava-roupas) e de uso profissional. A composição do detergente de uso profissional (informada pelo fabricante) consistiu de LAS, tensoativo não iônico, neutralizantes, alcalinizantes (hidróxido de sódio), sequestrantes, coadjuvantes, branqueador óptico e veículo. A formulação de detergente em pó comercial (lava-roupas) consistiu de LAS, coadjuvante, 
branqueadores, enzimas e fragâncias. Durante parte dos ensaios, observou-se mudança na composição de produtos usados na lavanderia comercial, com a adição de acidulante neutralizante (alterações nos parâmetros monitorados descrita no item 5.4.1.1, p. 103). A composição química desse acidulante neutralizante (informado pelo fabricante) consistiu de metabissulfito de sódio, sulfato de sódio anidro, sequestrantes, agente redutor anti-cloro e veículo alcalino.

A água do primeiro enxágue foi coletada em frascos de politereftalato de etileno (PET) (garrafas de água mineral reutilizada) e armazenada a $4^{\circ} \mathrm{C}$. Essa água foi diluída de forma a obter a concentração de LAS desejada e aplicada no reator UASB. A frequência de coleta da água residuária de lavanderia foi entre 2 a 4 semanas. Todas as amostras de águas residuárias coletadas da lavanderia comercial foram caracterizadas quanto à concentração de LAS, além de parâmetros como pH, alcalinidade, ácidos orgânicos voláteis (cromatografia líquida de alta eficiência - CLAE), demanda química de oxigênio (DQO) bruta e filtrada, sólidos, nitrogênio total Kjeldahl (NTK), sulfato, sulfeto, fluoreto, fosfato e nitrato (Tabela 4.8; p. 38).

\subsection{Inóculo}

Utilizou-se lodo granulado proveniente de reator UASB empregado no tratamento de água residuária de abatedouro de aves (Avícola Dacar S/A, Tietê/SP). Esse inóculo foi usado em todos os ensaios, mantendo-se intacta a forma granulada. 


\subsection{Determinação de isoterma de adsorção de LAS}

A fim de avaliar a adsorção de LAS no inóculo foram realizados ensaios em batelada, em duplicata, para determinar isoterma de adsorção. Frascos de $500 \mathrm{~mL}$ foram preenchidos com 250 mL de água residuária sintética (descrita anteriormente, p. 19). Adicionou-se inóculo na concentração de 7,2 g ST/L, e 5 a 45 mg/L de LAS inicial.

O inóculo foi previamente esterilizado em autoclave baseado em método descrito por Mogensen et al. (2003). Por três vezes, o inóculo foi autoclavado durante 60 min a $121^{\circ} \mathrm{C} \mathrm{e}$ 1 atm de pressão. Para evitar oxidação do surfactante, nitrogênio (100\%) foi fluxionado, durante 5 min, no headspace dos frascos, que em seguida foram fechados com tampa de butila. Os frascos foram mantidos em agitação de $150 \mathrm{rpm}$, a $30^{\circ} \mathrm{C}$, durante $24 \mathrm{~h}$.

Amostras para determinação da concentração de LAS foram coletadas antes da adição

de inóculo e ao final do ensaio. A concentração de LAS foi determinada por cromatografia líquida de alta eficiência (CLAE) (DUARTE et al., 2006).

Os dados de adsorção de LAS ao lodo granulado foram ajustados à equação de Freundlich (eq. 4.1 e Langmuir 4.2):

$$
q=K_{f} \times C^{1 / n} \quad \text { (Equação 4.1) }
$$

Sendo,

$q$ : concentração de LAS adsorvida por fase sólida (mg LAS/g),

$K_{f}$ : coeficiente de adsorção (L/g),

$C$ : concentração de equilíbrio da solução (mg LAS/L), e

$1 / n$ : ordem de potência relacionada ao mecanismo de adsorção. 


$$
\left.q=\frac{q_{\max } \times b \times C}{1+b \times C} \quad \text { (Equação } 4.2\right)
$$

Sendo,

q: capacidade de adsorção na concentração de equilíbrio (mg LAS/g)

$q_{\text {max }}$ : capacidade máxima de adsorção (mg LAS/g)

b: medida de afinidade do adsorbato pela superfície e acessibilidade da superfície (L/mg LAS), e

$C$ : concentração de equilíbrio da solução $(\mathrm{mg} / \mathrm{L})$

Para a verificação do ajuste à equação de Langmuir, a equação 4.2 foi reescrita para realizar ajuste linear entre os parâmetros $C / q$ e $C$ :

$$
\left.\frac{C}{q}=\frac{1}{q_{\max } \times b}+\frac{1}{q_{\max }} \times C \quad \text { (Equação } 4.3\right)
$$

\subsection{Degradação de LAS com diferentes co-substratos}

\subsubsection{Montagem experimental}

No ensaio foi usado reator UASB, denominado $\mathrm{R}_{\mathrm{UASB}}$, feito em acrílico e chapas metálicas, com volume de 10,5 L. O reator foi operado com TDH de $24 \mathrm{~h}$. O esquema experimental consistiu de alimentação mantida em refrigerador $\left(4^{\circ} \mathrm{C}\right)$, passando por banho térmico $\left(30^{\circ} \mathrm{C}\right)$ e bombeado ao reator (Figura 4.2). O uso de banho térmico foi necessário para equilibrar a temperatura do afluente (refrigerado a $\left.4^{\circ} \mathrm{C}\right)$ com a do reator $\left(30^{\circ} \mathrm{C}\right.$, mantida em câmara climatizada). A alimentação foi armazenada em frasco de vidro com bexiga contendo $\mathrm{N}_{2}(100 \%)$ (Figura 4.3a) e bombeada por uma bomba dosadora de diafragma (Prominent) ao 
reator UASB (Figura 4.3b), na vazão de $0,44 \mathrm{~L} / \mathrm{h}$. No topo do reator um coletor de gases foi ligado a um selo hídrico para permitir a amostragem de gases.

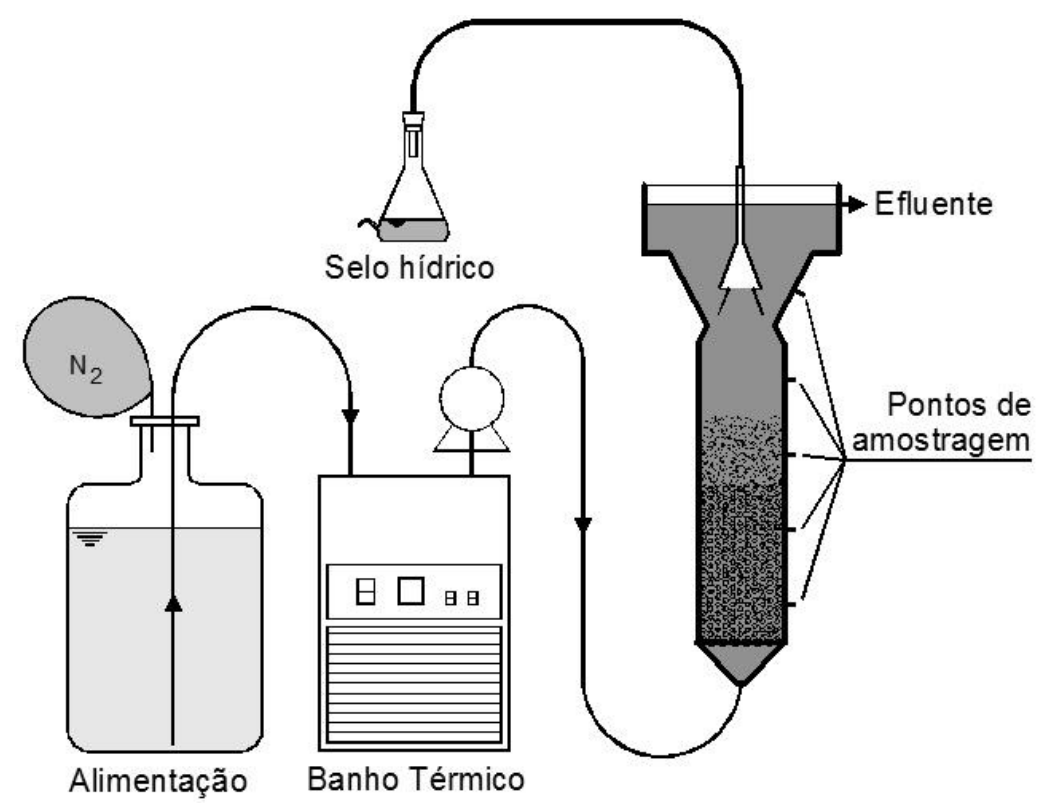

Figura 4.2: Esquema experimental do reator $\mathrm{R}_{\mathrm{UASB}}$

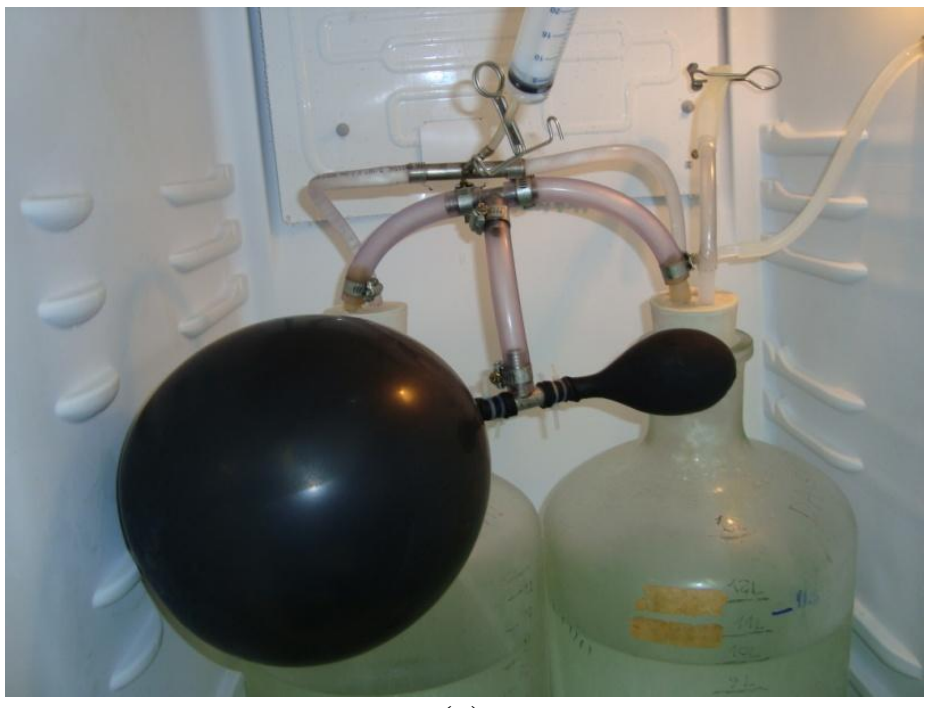

(a)

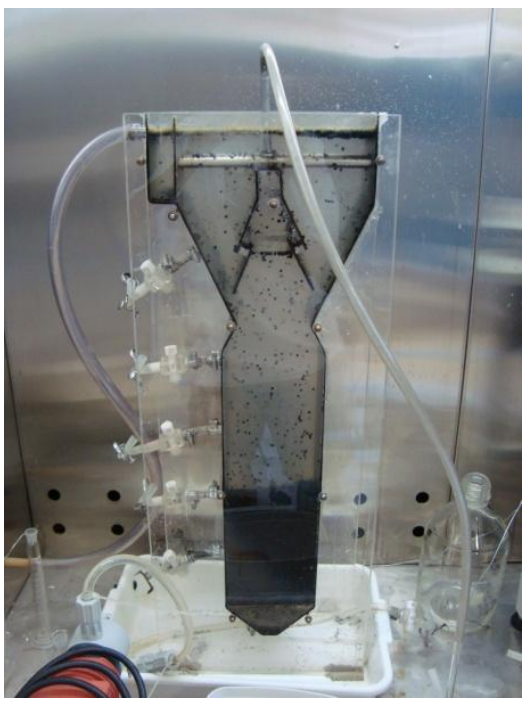

(b)

Figura 4.3: Frascos de alimentação (a) e reator $\mathrm{R}_{\mathrm{UASB}}$ durante operação (b) 


\subsubsection{Condições de operação}

Nesse ensaio a alimentação consistiu de água residuária sintética, supracitada no item 4.1, p. 19 (as concentrações de co-substratos encontram-se na Tabela 4.3). A operação do reator $\mathrm{R}_{\mathrm{UASB}}$ foi dividida em cinco etapas: (I) Adaptação; (II) Adição de LAS; (III) Recirculação de efluente; (IV) Aeração de água de abastecimento e recuperação; (V) Adição de extrato de levedura.

Na Etapa I foi usado na alimentação etanol como co-substrato, sem a adição de LAS, durante 30 dias. Na Etapa II, adicionou-se LAS (14 mg/L) e os co-substratos foram etanol e metanol (Tabela 4.3). Adicionou-se metanol no intuito de favorecer populações de Methanosarcina (BOONE e CASTENHOLZ, 2001), envolvidas na nucleação dos grânulos do inóculo. A partir da Etapa III iniciou-se a recirculação de efluente, com vazão de cinco vezes a vazão de alimentação. Na Etapa IV, ocorreu um incidente no preparo da água residuária sintética, causado pela aeração na água de abastecimento usada na alimentação. A presença de oxigênio na água residuária resultou em inibição das arquéias metanogênicas, consequentemente, reduzindo o consumo de ácido acético. Dessa forma, a aeração resultou em aumento da concentração efluente de ácidos voláteis. A recuperação (Etapa IV) consistiu da retirada de água residuária com alta concentração de ácidos voláteis, adição de tampão e redução da DQO afluente. Parte da água residuária do reator foi drenada, mantendo a manta de lodo submersa, e em seguida completou-se o volume com água de abastecimento, para diluir o restante de ácidos voláteis. Em seguida adicionou-se bicarbonato de sódio ao reator (5,6 g), para tamponar o meio. Por fim, reduziu-se a DQO afluente, para obter menor produção de ácidos voláteis. Decidiu-se reduzir a DQO em virtude da menor remoção de LAS observada em concentração de ácidos voláteis acima de 50 mg HAc/L (LOBNER et al., 2005), além da inibição de metanogênicas acetoclásticas na presença de LAS (MOSCHE e 
MEYER, 2002). Por fim, na Etapa V adicionou-se co-substrato complexo, extrato de levedura, além dos alcoóis de cadeia curta (etanol e metanol). Na Tabela 4.3 encontra-se resumo das condições experimentais de cada etapa.

Tabela 4.3: Condições experimentais do reator $\mathrm{R}_{\mathrm{UASB}}$

\begin{tabular}{lccccc}
\hline & I & II & III & IV & V \\
\hline Alimentação & & & & & \\
Etanol (mg DQO/L) & 900 & 550 & 500 & 150 & 200 \\
Metanol (mg DQO/L) & - & 550 & 500 & 150 & 200 \\
Extrato de levedura (mg DQO/L) & - & - & - & - & 200 \\
DQO (mg/L) & 900 & 1100 & 1000 & 300 & 600 \\
Carga orgânica específica (g DQO/g STV.d) & 0,14 & 0,2 & 0,2 & 0,06 & 0,2 \\
Taxa de carregamento orgânico (kg DQO/m³.d) & 0,9 & 1,2 & 1,1 & 0,3 & 0,6 \\
LAS (mg/L) & - & 14 & 14 & 14 & 14 \\
Recirculação do efluente & - & - & sim & sim & sim \\
Duração (d) & 30 & 140 & 26 & 51 & 44 \\
\hline
\end{tabular}

A DQO afluente variou de $900 \mathrm{mg} / \mathrm{L}$ a $1100 \mathrm{mg} / \mathrm{L}$ nas Etapas I, II e III (Tabela 4.3). Na Etapa IV, reduziu-se a concentração de DQO afluente para $300 \mathrm{mg} / \mathrm{L}$ para controlar a produção de ácidos orgânicos voláteis na recuperação do reator. Após a recuperação, aumentou-se a DQO afluente de forma a obter carga orgânica específica similar as Etapas I, II e III (em torno de 0,20 g DQO/g STV.d); assim, na Etapa V, a DQO afluente foi de $600 \mathrm{mg} / \mathrm{L}$.

$\mathrm{Na}$ Etapa II, excesso de biomassa suspensa foi retirado em virtude do entupimento da saída do efluente no $81^{\circ}$ dia de operação (10,5 g ST). Quantidade equivalente de inóculo foi reposta no $93^{\circ}$ dia, considerando que a biomassa perdida representava quase $13 \%$ dos sólidos totais do reator ao final da Etapa I. Para análise do balanço de massa de LAS, determinou-se a concentração de LAS adsorvido na biomassa retirada.

Durante a operação do reator foram monitorados: ácidos orgânicos voláteis (cromatografia gasosa - CG), alcalinidade, LAS (CLAE), metano (CG), DQO bruta, pH, sólidos suspensos, sulfato e sulfeto (Tabela 4.8, p. 38). 
Ao final de cada etapa foram coletadas amostras para exames microscópicos. Foram determinados sólidos (totais, voláteis e fixos) do reator ao final das Etapas I, II, IV e V. Não foi realizada medida de sólidos da Etapa III em virtude da curta duração (26 dias).

A variação do tamanho dos grânulos no reator foi avaliada no inóculo e ao fim das Etapas I, II, V e início da Etapa IV (em virtude da aeração da água de abastecimento, que impediu a determinação ao fim da Etapa III). Foram coletadas amostras no primeiro e segundo ponto de amostragem na Etapa I, e apenas no primeiro ponto de amostragem nas Etapas II, IV e V, em virtude da menor altura da manta de lodo nessas etapas. Na Etapa I, realizou-se amostragem de 150 medidas de cada ponto para compor o diâmetro médio, em um total de dois pontos de amostragem (total: 300 medidas). Em virtude da redução da manta de lodo (pela perda de sólidos), realizou-se amostragem de 300 medidas no primeiro ponto de amostragem nas demais etapas. No item 4.10 (p. 39) encontra-se descrito o método empregado para determinação da variação do tamanho dos grânulos.

Ao final da operação do reator, coletou-se amostra para determinação de LAS adsorvido na biomassa, baseado em método descrito por Duarte et al. (2008) (item 4.11, p. 39).

Ao fim das etapas de adição de LAS (II) e extrato de levedura (V) foi estimada a população de bactérias anaeróbias totais e arquéias metanogênicas, pela determinação do número mais provável (NMP) usando a técnica de tubos múltiplos (item 4.13.1, p. 40). Além disso, foram coletadas amostras para quantificações do domínio Archaea e Bacteria no reator, por meio da técnica de hibridação fluorescente in situ (fluorescent in situ hybridization FISH). Foram quantificadas as amostras ao fim das Etapas I, II e V, e início da Etapa IV, que, em virtude da aeração da água de abastecimento, impediu a determinação ao fim da Etapa III. No item 4.13 .2 (p. 41) encontra-se descrito as sondas e métodos usados na quantificação microbiana das amostras do reator. 
4.7 Avaliação da influência da biodisponibilidade de LAS, TDH e concentração de cosubstratos

\subsubsection{Montagem experimental}

Foram usados reatores UASB de tubo de vidro borosilicato, dotados de três pontos de amostragem (PA1, PA2, PA3) e distribuidor e separador de fases em aço (Figura 4.4). No topo e base do tubo de vidro borosilicato, foram posicionadas peneiras de aço para manter o lodo granulado nessa região. Os reatores possuíam volume útil de 0,65 L e foram operados em condição mesofílica (temperatura em $30 \pm 4^{\circ} \mathrm{C}$, mantida em câmara climatizada). A água residuária foi mantida em frasco de vidro, refrigerado a $4^{\circ} \mathrm{C}$, e bombeada por uma bomba dosadora peristáltica (Provitec).

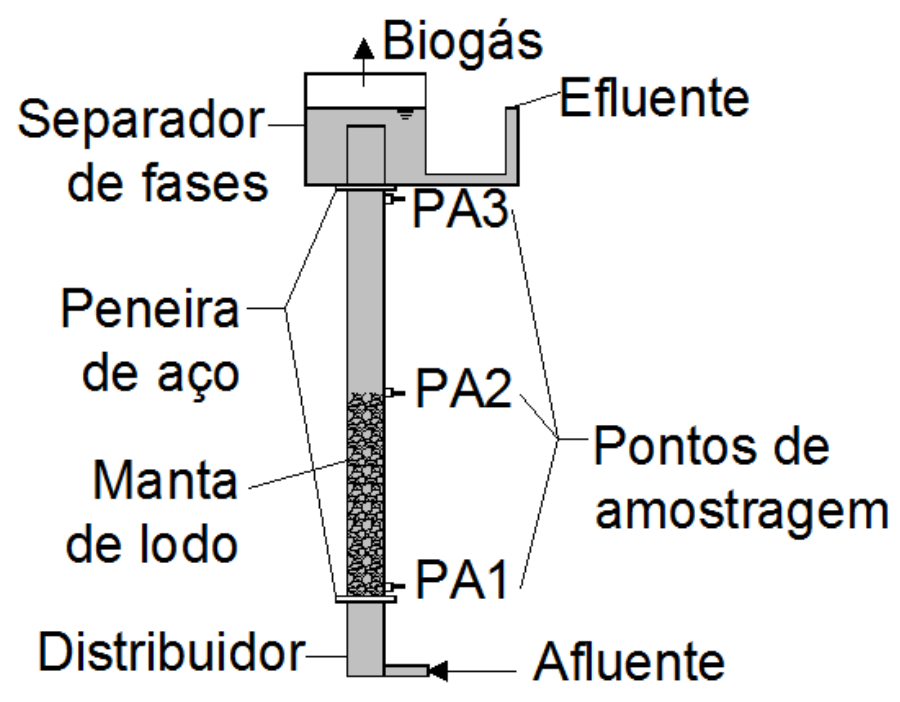

(a)

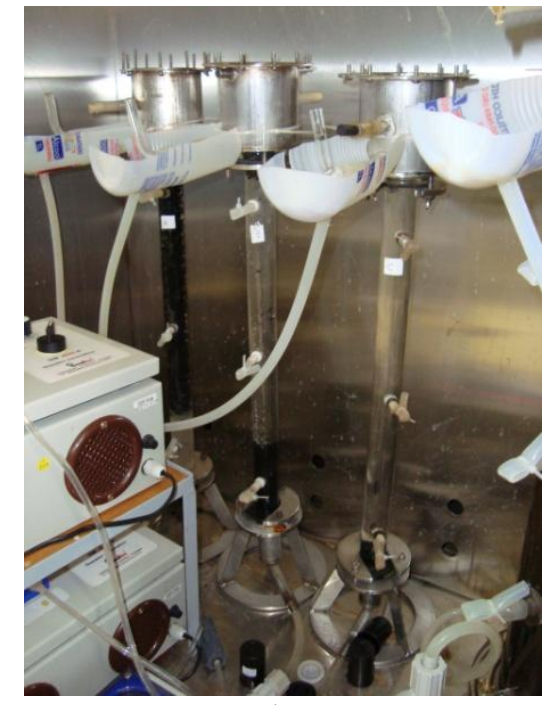

(b)

Figura 4.4: Esquema do reator UASB usado no experimento (a) e reatores UASB durante operação (b) 


\subsubsection{Condições de operação}

Nesse ensaio foram usados sete reatores UASB, aplicando concentração de LAS de 12-13 mg/L, durante 87 a 92 dias.

Nos reatores $R_{35 A}, R_{35 B}, R_{35 C}$ e $R_{35 D}$, variou-se o LAS biodisponível, por meio da concentração de biomassa. Nesses reatores, a concentração de biomassa foi de 1,3 a $16 \mathrm{~g} \mathrm{ST} \mathrm{L}^{3}$, resultando em carga específica de LAS entre 0,6 e 12,3 mg LAS/g STV.d. (Tabela 4.4). Esses quatro reatores foram operados com TDH de 35 h. A concentração de bicarbonato de sódio aplicada foi entre 400 e $800 \mathrm{mg} / \mathrm{L}$, para manter o pH efluente em torno de 7,0 .

Tabela 4.4: Condições experimentais do ensaio variando a concentração de biomassa

\begin{tabular}{lcccc}
\hline & $\mathrm{R}_{35 \mathrm{~A}}$ & $\mathrm{R}_{35 \mathrm{~B}}$ & $\mathrm{R}_{35 \mathrm{C}}$ & $\mathrm{R}_{35 \mathrm{D}}$ \\
\hline TDH (h) & 35 & 35 & 35 & 35 \\
Biomassa final & & & & \\
ST (g/L) & $16 \pm 3$ & $5,9 \pm 0,9$ & $2,3 \pm 0,7$ & $1,3 \pm 0,5$ \\
STV (g/L) & $13 \pm 2$ & $4,5 \pm 0,7$ & $1,5 \pm 0,5$ & $0,7 \pm 0,3$ \\
STF (g/L) & $2,5 \pm 0,6$ & $1,4 \pm 0,5$ & $0,8 \pm 0,4$ & $0,6 \pm 0,2$ \\
Carga orgânica aplicada & & & & \\
DQO (mg/L) & 3.450 & 480 & 240 & 105 \\
Taxa de carregamento orgânico & 2,30 & 0,32 & 0,16 & 0,07 \\
$\quad$ kg DQO/m³.d) & & & & \\
Carga orgânica específica & $0,18 \pm 0,06$ & $0,07 \pm 0,02$ & $0,10 \pm 0,02$ & $0,10 \pm 0,02$ \\
$\quad$ g DQO/g STV.d) & & & & \\
LAS & $12 \pm 2$ & $13 \pm 3$ & $13 \pm 2$ & $12 \pm 2$ \\
$\quad$ Afluente (mg/L) & 0,6 & 2,0 & 6,1 & 12,3 \\
Carga específica de LAS & & & & \\
$\quad$ (mg/g STV.d) & 1150 & 160 & 80 & 35 \\
Alimentação & 1150 & 160 & 80 & 35 \\
Etanol (mg DQO/L) & 1150 & 160 & 80 & 35 \\
$\quad$ Metanol (mg DQO/L) & 800 & 400 & 400 & 600 \\
Extrato de levedura (mg DQO/L) & 90 & 89 & 89 & 89 \\
$\quad$ Bicarbonato de sódio (mg/L) & & &
\end{tabular}

\footnotetext{
${ }^{3}$ Optou-se por apresentar a concentração de biomassa em sólidos totais por representar melhor a disponibilidade de sítios de adsorção
} 
Tabela 4.5: Condições experimentais do ensaio variando o TDH e a concentração de cosubstratos

\begin{tabular}{lccc}
\hline & $\mathrm{R}_{6 \mathrm{~h}}$ & $\mathrm{R}_{80 \mathrm{~h}}$ & $\mathrm{R}_{\mathrm{BCS}}$ \\
\hline TDH (h) & 6 & 80 & 35 \\
Biomassa final & & & \\
ST (g/L) & $6 \pm 1$ & $1,7 \pm 0,5$ & $1,6 \pm 0,5$ \\
STV (g/L) & $5 \pm 1$ & $1,1 \pm 0,4$ & $1,3 \pm 0,4$ \\
STF (g/L) & $0,6 \pm 0,2$ & $0,6 \pm 0,2$ & $0,3 \pm 0,1$ \\
Carga orgânica aplicada & & & \\
DQO (mg/L) & 210 & 180 & 60 \\
Taxa de carregamento orgânico (kg DQO/m³.d) & 0,84 & 0,05 & 0,04 \\
Carga orgânica específica (g DQO/g STV.d) & $0,18 \pm 0,04$ & $0,05 \pm 0,02$ & $0,03 \pm 0,02$ \\
LAS & & & \\
Afluente (mg/L) & $12 \pm 2$ & $12 \pm 2$ & $12 \pm 2$ \\
Carga específica de LAS (mg/g STV.d) & 10,1 & 3,9 & 6,5 \\
Alimentação & & & \\
Etanol (mg DQO/L) & 70 & 60 & 20 \\
Metanol (mg DQO/L) & 70 & 60 & 20 \\
Extrato de levedura (mg DQO/L) & 70 & 60 & 20 \\
Bicarbonato de sódio (mg/L) & 400 & 600 & 700 \\
Duração (d) & 92 & 87 & 92 \\
\hline
\end{tabular}

Nos reatores $R_{6}$ e $R_{80}$ variou-se o TDH em 6 h e 80 h, respectivamente. Nesses reatores, a carga orgânica especifica foi de 0,05 e 0,18 g DQO/g STV.d, respectivamente. A concentração de bicarbonato de sódio aplicada foi entre 400 e 600 mg/L (Tabela 4.5).

No reator $\mathrm{R}_{\mathrm{BCS}}$, aplicou-se a menor concentração de co-substratos (carga orgânica específica de $0,03 \mathrm{~g} \mathrm{DQO} / \mathrm{g}$ STV.d). O reator $\mathrm{R}_{\mathrm{BCS}}$ foi operado com TDH de $35 \mathrm{~h}$, sendo adicionado bicarbonato de sódio na concentração de $700 \mathrm{mg} / \mathrm{L}$ para manter o pH efluente em torno de 7,0 (Tabela 4.5).

A alimentação dos reatores consistiu de água residuária sintética, supracitado no item 4.1, p. 19 (as concentrações de co-substratos encontram-se na Tabela 4.4 e Tabela 4.5). Após 30 dias de adaptação sem surfactante, adicionou-se LAS comercial em concentração em torno de 12-13 mg/L. As quantidades de co-substratos foram definidas de forma a obter carga orgânica específica entre 0,03 e 0,18 g DQO/g STV.d. 
Os seguintes parâmetros foram analisados: ácidos orgânicos voláteis (CLAE), alcalinidade, DQO bruta, pH, LAS e sólidos suspensos (Tabela 4.8. p. 38). Esses parâmetros foram monitorados a partir da adição de LAS.

No $33^{\circ}$ dia adicionou-se resazurina na alimentação para avaliar a condição ao longo do reator (anaeróbia restrita $=$ incolor, anaeróbia facultativa $=$ coloração rosa, aeróbia $=$ coloração azul).

Próximo do final do ensaio (entre 80 e 90 dias de operação) foram medidas as variações espaciais de LAS e ácidos orgânicos voláteis (CLAE) no afluente, pontos de amostragem (PA1, PA2, PA3) e efluente (Figura 4.4).

Ao final do ensaio foram determinados os sólidos dos reatores (totais, voláteis e fixos) e a concentração de LAS adsorvida na biomassa (método descrito no item 4.11, p. 39).

Exames microscópicos foram realizados para caracterizar as morfologias presentes ao fim do ensaio. Além disso, amostras da biomassa na manta de lodo e no separador de fases foram coletadas de todos os reatores, com exceção de $R_{35 A}$, para análise da comunidade microbiana do domínio Archaea e Bacteria pela técnica de PCR-DGGE (item 4.13.3, p. 44).

Para avaliar a interação entre biodisponibilidade de LAS, TDH e concentração de cosubstratos na degradação de LAS, determinou-se a matriz de correlação (Pearson). A partir dos dados de todos os reatores, relacionou-se a degradação de LAS com a concentração de sólidos totais (expressando a biodisponibilidade de LAS), TDH e carga orgânica específica (expressando a concentração de co-substratos). 


\subsection{Degradação de LAS em água residuária de lavanderia}

\subsubsection{Montagem experimental}

Foram usados quatros reatores UASB, dois na Parte 1 e dois na Parte 2, todos operados com TDH de $35 \mathrm{~h}$. As características dos reatores UASB usados encontram-se descritas no item 4.7.1, p. 28.

\subsubsection{Condições de operação}

\subsubsection{Parte 1}

Na Parte 1 foi avaliada a degradação de $10 \mathrm{mg} / \mathrm{L}$ de LAS, tanto em água residuária proveniente de lavanderia (reator $\mathrm{R}_{\mathrm{L} 1}$ ) como de água residuária sintética com surfactante padrão (reator $\mathrm{R}_{\mathrm{S} 1}$ ). Durante 15 dias dois reatores foram alimentados com água residuária sintética sem surfactante (supracitado no item 4.1, p. 19), segundo composição de cosubstratos do reator $\mathrm{R}_{\mathrm{S} 1}$ (Tabela 4.6). Após esse período, alimentou-se o reator $\mathrm{R}_{\mathrm{L} 1}$ com água residuária de lavanderia diluída e no reator $\mathrm{R}_{\mathrm{S} 1}$ acrescentou-se surfactante à água residuária sintética. Aplicou-se concentração de LAS em torno de $10 \mathrm{mg} / \mathrm{L}$ nos dois reatores, durante 97 dias. 
Tabela 4.6: Condição experimental da Parte 1

\begin{tabular}{lcc}
\hline & $\mathrm{R}_{\mathrm{L} 1}$ & $\mathrm{R}_{\mathrm{S} 1}$ \\
\hline Biomassa final & & \\
ST $(\mathrm{g} / \mathrm{L})$ & $0,58 \pm 0,12$ & $1,56 \pm 0,13$ \\
$\mathrm{STV}(\mathrm{g} / \mathrm{L})$ & $0,45 \pm 0,09$ & $0,50 \pm 0,09$ \\
STF (g/L) & $0,13 \pm 0,05$ & $1,05 \pm 0,07$ \\
Carga orgânica aplicada & 130 & \\
DQO (mg/L) & 0,09 & 0,06 \\
Taxa de carregamento orgânico (kg DQO/m³.d) & $0,20 \pm 0,09$ & $0,12 \pm 0,04$ \\
Carga orgânica específica (g DQO/g STV.d) & $11 \pm 3$ & $10 \pm 3$ \\
LAS (mg/L) & & \\
Alimentação & - & 30 \\
Etanol (mg DQO/L) & - & 30 \\
Metanol (mg DQO/L) & - & 30 \\
Extrato de levedura (mg DQO/L) & 400 & 1000 \\
Bicarbonato de sódio (mg/L) & 97 & 97 \\
Duração (d) &
\end{tabular}

A quantidade de co-substrato foi definida de forma a obter carga orgânica específica em torno de 0,10-0,20 g DQO/g STV.d (Tabela 4.6). Adicionou-se bicarbonato de sódio para tamponar o meio, em concentração de $400 \mathrm{mg} / \mathrm{L}$ no reator $\mathrm{R}_{\mathrm{L} 1}$ (água residuária de lavanderia) e $1.000 \mathrm{mg} / \mathrm{L}$ no reator $\mathrm{R}_{\mathrm{S} 1}$ (água residuária sintética).

Os dois reatores foram inoculados com lodo granulado (item 4.4, p. 21), em concentração inicial de 0,14 g ST/L (STV: 0,12 g/L). Considerou-se na determinação de parâmetros específicos os valores finais de sólidos totais voláteis (STV) (Tabela 4.6).

No $27^{\circ}$ dia de operação, o topo do separador de fases foi fechado e instalou-se um selo hídrico na saída de coleta de biogás, no intuito de reduzir a difusão de oxigênio nessa região. Todavia, não se verificou mudança da condição no separador de fases (que se manteve anaeróbia facultativa como observado nos ensaios anteriores - item 5.3, p. 73).

Durante o ensaio, foram monitorados: alcalinidade, ácidos orgânicos voláteis (CLAE), DQO bruta, LAS, pH, sólidos suspensos, sulfato e sulfeto (Tabela 4.8, p. 38).

Entre o $60^{\circ}$ e $75^{\circ}$ dias de operação foram coletadas amostras para determinação de sólidos suspensos totais (SST) do efluente, para determinação da concentração de LAS 
adsorvido. Devido à baixa concentração de sólidos suspensos $(<20 \mathrm{mg} / \mathrm{L})$ usou-se um aparato para acumular sólidos no fundo, durante 15 dias (Figura 4.5).

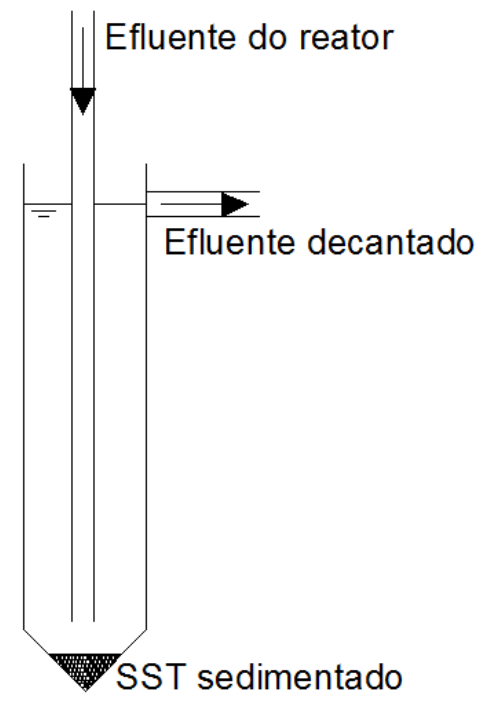

(a)

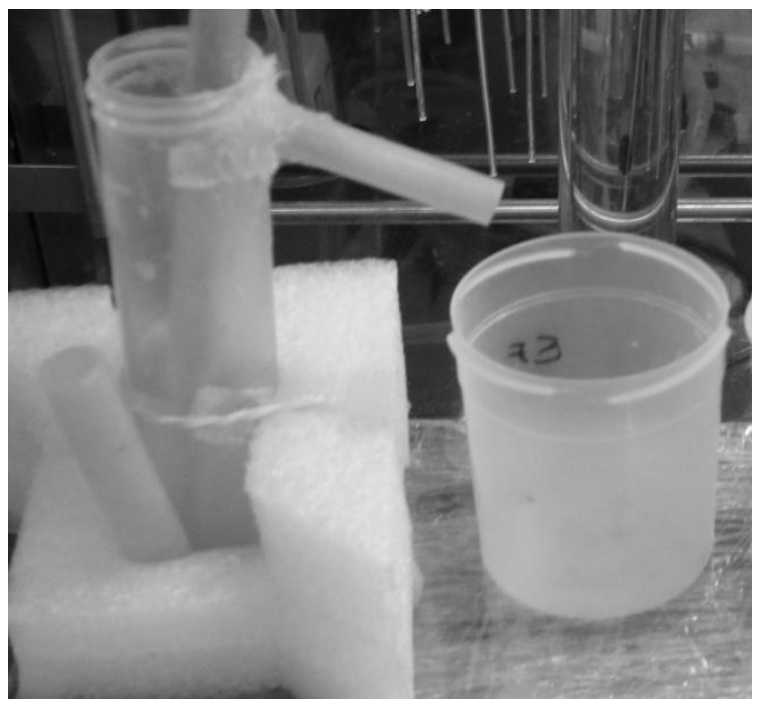

(b)

Figura 4.5: Esquema (a) e foto (b) do aparato para acúmulo de sólidos suspensos

Aos 79 dias do ensaio, foi realizada análise da variação espacial de LAS e ácidos orgânicos voláteis (CLAE), no afluente, pontos de amostragem (PA1, PA2 e PA3) e efluente (Figura 4.4). Também aos 79 dias do ensaio aplicou-se o indicador resazurina na alimentação.

No final do ensaio foi retirada amostra para determinação de sólidos da biomassa do reator e concentração de LAS adsorvida na biomassa (método no item 4.11, p. 39). Amostras da manta de lodo e da biomassa do separador de fases foram coletadas para caracterização da diversidade filogenética, mediante análise de pirosequenciamento (item 4.13.4, p. 45).

\subsubsection{Parte 2}

$\mathrm{Na}$ Parte 2 foi avaliada a degradação de LAS em dois reatores, um com água residuária de lavanderia (reator $\mathrm{R}_{\mathrm{L} 2}$ ), e outro alimentado com água residuária sintética e 
surfactante (reator $\mathrm{R}_{\mathrm{S} 2}$ ). $\mathrm{O}$ reator $\mathrm{R}_{\mathrm{L} 2}$ foi alimentado com água residuária de lavanderia diluída, contendo LAS em concentração entre 10 e 20 mg/L.

No reator $\mathrm{R}_{\mathrm{S2}}$, efetuou-se modificação na água residuária sintética, com a redução da concentração de cloreto de amônio $\left(\mathrm{NH}_{4} \mathrm{Cl}\right)$ de 1.000 para $20 \mathrm{mg} / \mathrm{L}$. Essa modificação teve por objetivo reduzir a concentração de nitrogênio afluente para $5 \mathrm{mg} \mathrm{N} / \mathrm{L}$, uma vez que se estimou concentração entre 1 e $5 \mathrm{mg}$ N/L na água residuária de lavanderia diluída da Parte 1 (baseado na caracterização e diluições adotadas). Manteve-se a composição da solução de vitaminas e o uso de etanol, metanol e extrato de levedura como co-substratos. As concentrações de co-substratos foram definidas para obter carga orgânica específica em torno de 0,10 g DQO/g STV.d (Tabela 4.7).

Tabela 4.7: Condição experimental da Parte 2

\begin{tabular}{lcc}
\hline & $\mathrm{R}_{\mathrm{L} 2}$ & $\mathrm{R}_{\mathrm{S} 2}$ \\
\hline Biomassa final & & \\
ST (g/L) & $2,4 \pm 0,8$ & $2,1 \pm 0,7$ \\
STV (g/L) & $1,7 \pm 0,4$ & $1,5 \pm 0,3$ \\
STF (g/L) & $0,7 \pm 0,2$ & $0,6 \pm 0,1$ \\
Carga orgânica aplicada & & \\
DQO (mg/L) & 140 & 210 \\
Taxa de carregamento orgânico (kg DQO/m $\left.{ }^{3} . \mathrm{d}\right)$ & 0,09 & 0,14 \\
Carga orgânica específica (g DQO/g STV.d) & $0,11 \pm 0,07$ & $0,16 \pm 0,08$ \\
LAS (mg/L) & $13 \pm 6$ & $11 \pm 2$ \\
Alimentação & & \\
Etanol (mg DQO/L) & - & 70 \\
Metanol (mg DQO/L) & - & 70 \\
Extrato de levedura (mg DQO/L) & - & 70 \\
Bicarbonato de sódio (mg/L) & 700 & 700 \\
Duração (d) & 115 & 115 \\
\hline
\end{tabular}

Em princípio, a meta da parte 2 era aplicar LAS na concentração inicial de $10 \mathrm{mg} / \mathrm{L}$, aumentando para $20 \mathrm{mg} / \mathrm{L}$ e, eventualmente, $30 \mathrm{mg} / \mathrm{L}$. Todavia, a modificação da água residuária sintética resultou em eficiências de remoção de LAS bem menores que as observadas no ensaio anterior $(<40 \%)$ e, além disso, foi observada alteração na composição da água residuária de lavanderia. A partir do $52^{\circ}$ dia de operação do reator $\mathrm{R}_{\mathrm{L} 2}$, observou-se 
redução de $\mathrm{pH}$ (de 11 para 9) e alcalinidade (de 1.000 para $350 \mathrm{mg} \mathrm{CaCO}_{3} / \mathrm{L}$ ), e aumento de sulfato (de 115 para $280 \mathrm{mg} \mathrm{S/L)} \mathrm{(item} \mathrm{5.4.1.1,} \mathrm{p.} \mathrm{103)} \mathrm{em} \mathrm{virtude} \mathrm{da} \mathrm{adição} \mathrm{de} \mathrm{acidulante}$ neutralizante na composição de produtos usados na lavanderia comercial. Como esse foi o último ensaio realizado, não houve tempo suficiente para seguir adiante com a meta inicialmente estabelecida. Dessa forma, mantiveram-se as concentrações de LAS em torno de 10 mg/L em ambos os reatores (apesar disso, foi observada maior oscilação da concentração de LAS afluente no reator com água residuária de lavanderia, entre 10 e 20 mg/L).

No $52^{\circ}$ dia de operação do reator $\mathrm{R}_{\mathrm{L} 2}$, observou-se alta concentração de DQO e LAS (5.200 mg/L e $320 \mathrm{mg} / \mathrm{L}$, respectivamente) na água residuária de lavanderia. Além disso, a partir do $52^{\circ}$ dia de operação foi observada alteração na composição da água residuária de lavanderia. Assim, dividiu-se a operação do reator $\mathrm{R}_{\mathrm{L} 2}$ em duas etapas: a primeira até o $52^{\circ}$ dia (Etapa 2.1), e a segunda (Etapa 2.2) com duração de 63 dias, totalizando 115 dias de operação.

Adicionou-se bicarbonato de sódio para tamponar o meio na concentração de $700 \mathrm{mg} / \mathrm{L}$ nos dois reatores (Tabela 4.7). Devido ao alto pH da água de lavanderia (em torno de 9-12), adotou-se a redução de pH com ácido clorídrico. Em virtude da correção de pH, aumentou-se a concentração de bicarbonato de sódio no reator alimentado com água residuária de lavanderia $\left(\mathrm{R}_{\mathrm{L} 2}\right)$ (concentração na Parte 1: $400 \mathrm{mg} / \mathrm{L}$ ).

Dois reatores UASB foram inoculados com lodo granulado, em concentração inicial de 2,1 g ST/L (STV: 1,8 g/L). Determinou-se a variação do tamanho dos grânulos no início e ao fim do ensaio (método descrito em 4.10, p. 39). Em virtude da quantidade de biomassa presente, foi possível a determinação do diâmetro de praticamente todos os grânulos usados no ensaio. Dessas medidas, foram amostradas 400 para determinação de box-plot e diâmetro médio em cada amostra (início e fim do ensaio). 
Os dois reatores foram alimentados com água residuária sintética sem surfactante durante 15 dias. Após esse período o reator $\mathrm{R}_{\mathrm{L} 2}$ foi alimentado com água residuária de lavanderia diluída (LAS: $10-20 \mathrm{mg} / \mathrm{L}$ ) e o reator $\mathrm{R}_{\mathrm{S} 2}$ com água residuária sintética e LAS (10 mg/L). A montagem experimental teve o topo do separador de fases selado, como realizado na Parte 1 (item 4.8.2.1, p. 33).

Durante o ensaio, foram monitorados: alcalinidade, ácidos orgânicos voláteis (CLAE), DQO bruta, LAS, pH e sólidos suspensos (Tabela 4.8). No reator alimentado com água residuária de lavanderia $\left(\mathrm{R}_{\mathrm{L} 2}\right)$ passou-se a monitorar sulfato e sulfeto a partir do $66^{\circ}$ dia.

No $107^{\circ}$ dia, realizou-se análise da variação espacial de LAS e ácidos orgânicos voláteis (CLAE), no afluente, pontos de amostragem (PA1, PA2 e PA3) e efluente (Figura 4.4, p. 28).

Ao final do ensaio foram realizadas análise dos sólidos da biomassa do reator (totais, voláteis, fixos) e a concentração de LAS adsorvida na biomassa (método descrito no item 4.11, p. 39).

\subsection{Análises físico-químicas e cromatográficas}

Na Tabela 4.8 encontram-se os parâmetros monitorados, métodos utilizados e respectivas referências.

LAS foi quantificado por meio de cromatografia líquida de alta eficiência (CLAE) (DUARTE et al., 2006). Utilizou-se sistema Shimadzu com detector de fluorescência

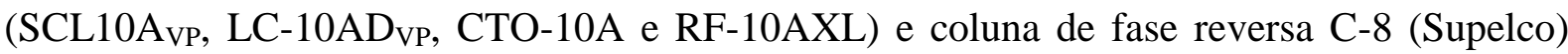
(porosidade de $5 \mu \mathrm{m}, 15 \mathrm{~cm}$ de comprimento e 4,6 $\mathrm{mm}$ de diâmetro interno). A fase móvel consistiu de metanol (100\%) e solução de $\mathrm{NaClO}_{4}$ 0,075 M (em água ultrapurificada). A 
curva de calibração adotada possuía valores entre 5 e $40 \mathrm{mg} / \mathrm{L}$, com limites de detecção e quantificação entre 0,77-1,13 e 2,29-3,77 mg/L, respectivamente.

Os ácidos orgânicos voláteis foram quantificados por dois métodos: cromatografia gasosa (CG) (MORAES et al., 2000) e CLAE (LAZARO et al., 2008). A determinação de ácidos orgânicos voláteis por CG foi realizada em cromatógrafo Shimadzu, modelo GC-2010, com coluna HP-Innovax (30 m de comprimento, 0,25 $\mathrm{mm}$ de diâmetro e 0,50 $\mu \mathrm{m}$ de porosidade). Os ácidos orgânicos voláteis quantificados por CLAE foram determinados em sistema Shimadzu (SCL10A $A_{V P}$, LC-10AD HPX-87H (Biorad).

Tabela 4.8: Parâmetros físico-químicos monitorados

\begin{tabular}{|c|c|c|}
\hline Parâmetro & Método & Referência \\
\hline $\begin{array}{l}\text { Ácidos orgânicos voláteis } \\
\text { (acético, propiônico, butírico, isobutírico, } \\
\text { valérico, isovalérico, capróico) }\end{array}$ & $\mathrm{CG}^{1}$ & Moraes et al. (2000) \\
\hline $\begin{array}{l}\text { Ácidos orgânicos voláteis } \\
\text { (acético, butírico, isobutírico, capróico, } \\
\text { cítrico, fórmico, lático, málico, propiônico, } \\
\text { succínico, valérico e isovalérico) }\end{array}$ & CLAE $^{2}$ & Lazaro et al. (2008) \\
\hline Alcalinidade & Titulométrico & Ripley et al. (1986) \\
\hline DQO bruta e filtrada (membrana $1,2 \mu \mathrm{m}$ ) & Espectrofotométrico & APHA (2005) \\
\hline Fluoreto, fosfato e nitrato & $\begin{array}{l}\text { Cromatografia de } \\
\text { íons }\end{array}$ & EPA (1993) \\
\hline LAS & CLAE $^{2}$ & Duarte et al. (2006) \\
\hline Nitrogênio Total Kjeldahl (NTK) & Titulométrico & APHA (2005) \\
\hline $\mathrm{pH}$ & Potenciométrico & APHA (2005) \\
\hline $\begin{array}{l}\text { Sólidos dissolvidos, suspensos (membrana } \\
1,2 \mu \mathrm{m} \text { ) e totais }\end{array}$ & Gravimétrico & APHA (2005) \\
\hline Sulfato & Turbidimétrico & APHA (2005) \\
\hline Sulfeto & Espectrofotométrico & APHA (2005) \\
\hline
\end{tabular}

${ }^{1}$ Cromatografia gasosa

${ }^{2}$ Cromatografia líquida de alta eficiência

Fluoreto, fosfato e nitrato foram quantificados por cromatografia de íons, em cromatógrafo Dionex, modelo ICS-3000. As amostras dessa determinação foram previamente purificadas em coluna de fase sólida C-18, para remoção do surfactante. 


\subsection{Granulometria}

Determinou-se a variação do diâmetro médio dos grânulos baseado em método descrito por Alphenaar et al. (1993). Os grânulos foram dispostos em uma placa de Petri sobre uma folha com escala, para captura de imagens (Figura 5.7, p. 59). Essas imagens foram analisadas no software Image-Pro Plus 4.5, para contagem e determinação do diâmetro médio dos grânulos.

\subsection{Determinação de LAS adsorvido em biomassa}

A determinação de LAS adsorvido em biomassa foi baseada em método descrito por Duarte et al. (2008). Por três vezes, amostra seca foi imersa em metanol, em banho de ultrassom durante $30 \mathrm{~min}$. Ao fim de cada banho de ultrassom a amostra foi centrifugada a $6.000 \mathrm{rpm}$ (temperatura: $4^{\circ} \mathrm{C}$ ), sendo guardado o sobrenadante. No quarto banho de ultrassom, a amostra foi imersa em água ultrapurificada, centrifugada nas condições descritas anteriormente e guardado o sobrenadante. Os sobrenadantes coletados após os quatro banhos de ultrassom foram misturados, e sua concentração de LAS determinada por CLAE (item 4.9, p. 37). 


\subsection{Exames microscópicos}

Os exames de microscopia de contraste de fase e fluorescência foram realizados em microscópio Olympus BX60, acoplado à câmera com captura de imagem e software ImagePro Plus 4.5.

\subsection{Análises microbiológicas}

\subsubsection{Número mais provável (NMP)}

Determinou-se a estimativa das populações de bactérias anaeróbias totais e arquéias metanogênicas por meio da técnica de tubos múltiplos por número mais provável (NMP). A leitura referente à série de tubos positivos e negativos foi realizada por meio da tabela de NMP do Standard Methods (APHA, 2005).

Para o desprendimento da biomassa das amostras utilizou-se protocolo descrito por Vazoller (1995). Os grânulos foram macerados com auxilio de cadinho e almofariz; em seguida foi transferido $1 \mathrm{~mL}$ dessa biomassa em frasco de antibiótico contendo $9 \mathrm{~mL}$ de

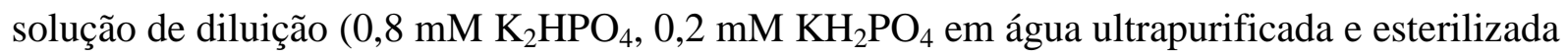
em autoclave, $1 \mathrm{~atm}, 121{ }^{\circ} \mathrm{C}, 20 \mathrm{~min}$ ). Utilizou-se esse frasco para proceder as demais diluições. Antes da diluição, procedeu-se a preparação dos frascos de diluição, adicionando 9 $\mathrm{mL}$ de água de diluição sob atmosfera de $\mathrm{N}_{2}(100 \%)$. Os frascos foram lacrados com tampa de butila e lacre de alumínio, e transferidos para autoclave, a $1 \mathrm{~atm}, 121^{\circ} \mathrm{C}$, durante $20 \mathrm{~min}$. 
Os frascos de diluição foram usados para retirar $1 \mathrm{~mL}$ da amostra diluída e proceder a sua transferência para os frascos de contagem de NMP. Cada frasco de contagem continha 8,9 $\mathrm{mL}$ de meio de cultura específico e $0,1 \mathrm{~mL}$ de solução redutora $\left(5 \% \mathrm{Na}_{2} \mathrm{~S}\right)$. Essa transferência foi em ambiente de assepsia, usando seringa estéril e previamente lavada com $\mathrm{N}_{2}(100 \%)$. A composição do meio de cultura específico foi similar à água residuária sintética nas Etapas II e V (item 4.6.2, p. 26), das quais foi realizada a contagem. Nessas etapas a concentração de LAS era de $14 \mathrm{mg} / \mathrm{L}$. Esse meio de cultura específico foi esterilizado em membrana filtrante $(0,22 \mu \mathrm{m})$ e sistema Millipore previamente esterilizados em autoclave ( $\left.1 \mathrm{~atm}, 121^{\circ} \mathrm{C}, 20 \mathrm{~min}\right)$. Após filtragem o meio de cultura específico foi submetido à atmosfera de $\mathrm{N}_{2}(100 \%)$ durante 20 minutos e troca de atmosfera $\mathrm{N}_{2} / \mathrm{CO}_{2}(70 / 30 \%)$. Os frascos de contagem foram incubados a $30 \pm 1^{\circ} \mathrm{C}$ durante 30 dias. As bactérias anaeróbias totais foram quantificadas pela turvação do meio para cada diluição e as arquéias metanogênicas pela produção de metano (CG) (SAKAMOTO e VARESCHE, 2011).

\subsubsection{Hibridação fluorescente in situ (FISH)}

As quantificações microbianas do lodo granulado foram realizadas por meio da técnica de hibridação fluorescente in situ (fluorescent in situ hybridization - FISH) usando sondas de oligonucleotídeos específicos para os microrganismos do domínio Bacteria (EUB338; AMANN et al., 1990), controle negativo NON338 (MANZ et al., 1992) e domínio Archaea (ARC915; STAHL e AMANN, 1991) com marcação fluorescente Rodamina ou CY3 na extremidade 5' (Tabela 4.9). 
Tabela 4.9: Sondas de oligonucleotídeos para hibridação in situ fluorescente

\begin{tabular}{ccccc}
\hline \multirow{2}{*}{ Sonda } & $\begin{array}{c}\text { Especi- } \\
\text { ficidade }\end{array}$ & Sequência $\left(5^{\prime} \rightarrow 3^{\prime}\right)$ & $\begin{array}{c}\text { Sítio do RNAr } \\
16 S\end{array}$ & Referência \\
\hline \multirow{2}{*}{ ARC915 } & $\begin{array}{l}\text { domínio } \\
\text { Archaea }\end{array}$ & GTGCTCCCCCGCCAATTCCT & $915-934$ & $\begin{array}{c}\text { Stahl \& Amann } \\
(1991)\end{array}$ \\
\multirow{2}{*}{ EUB338 } & $\begin{array}{l}\text { domínio } \\
\text { Bacteria }\end{array}$ & GCTGCCTCCCGTAGGAGT & $338-355$ & $\begin{array}{c}\text { Amann } \text { et al. } \\
(1990)\end{array}$ \\
NON338 & $\begin{array}{l}\text { Controle } \\
\text { negativo }\end{array}$ & ACTCCTACGGGAGGCAGC & $338-355$ & Manz et al. $(1992)$ \\
\hline
\end{tabular}

O desprendimento das amostras consistiu da agitação de $1 \mathrm{~mL}$ de amostra macerada, em ângulo de $45^{\circ}$ por $20 \mathrm{~min}$, em frasco esterilizado contendo cerca de $2 \mathrm{~g}$ de pérolas de vidro e $4 \mathrm{~mL}$ de solução tampão fosfato salino (PBS 1X: $130 \mathrm{mM} \mathrm{NaCl}, 7 \mathrm{mM} \mathrm{Na} 2 \mathrm{HPO}_{4}$, $3 \mathrm{mM} \mathrm{NaH} \mathrm{PO}_{4}, \mathrm{pH}$ 7,2). Em seguida, a amostra foi mantida em banho de ultrassom, durante $10 \mathrm{~min}$, e $1 \mathrm{~mL}$ (em triplicata) da amostra desprendida foi centrifugada a $9.000 \mathrm{rpm}$ por 1 min. As amostras desprendidas foram lavadas e fixadas conforme procedimento descrito por Araújo (2001); as concentrações finais das sondas usadas encontram-se na Tabela 4.10 e os protocolos de hibridação encontram-se resumidos na Tabela 4.11.

Tabela 4.10: Concentrações finais de cada sonda

\begin{tabular}{cc}
\hline Sonda & Concentração final usada na hibridação $(\mathrm{ng} / \mu \mathrm{L})$ \\
\hline EUB338 & 44,0 \\
NON338 & 41,8 \\
ARC915 & 39,5 \\
\hline
\end{tabular}


Tabela 4.11: Protocolo de hibridação

\begin{tabular}{|c|c|c|c|c|c|}
\hline Sonda & $\begin{array}{c}\text { Temperatura e } \\
\text { tempo de } \\
\text { hibridação }\end{array}$ & $\begin{array}{l}\text { Tampão de } \\
\text { hibridação }\end{array}$ & $\begin{array}{c}\text { Temperatura } \\
\text { e tempo de } \\
\text { lavagem }\end{array}$ & $\begin{array}{c}\text { Tampão de } \\
\text { lavagem }\end{array}$ & Referência \\
\hline ARC915 & $\begin{array}{c}45^{\circ} \mathrm{C} \\
2 \mathrm{~h}\end{array}$ & $\begin{array}{l}0,9 \mathrm{M} \quad \mathrm{NaCl}, \\
20 \mathrm{mM} \text { Tris-HCl} \\
(\mathrm{pH} 7,2), 10 \mathrm{mM} \\
\text { EDTA, } 0,01 \% \\
\text { SDS }+20 \% \\
\text { formamida }\end{array}$ & $\begin{array}{c}48^{\circ} \mathrm{C} \\
20 \mathrm{~min}\end{array}$ & $\begin{array}{ll}20 \mathrm{mM} & \text { Tris- } \\
\mathrm{HCl}(\mathrm{pH} & 7,2), \\
10 \mathrm{mM} & \text { EDTA, } \\
0,01 \% & \text { SDS } \\
\text { com } 225 \mathrm{mM} \\
\mathrm{NaCl}\end{array}$ & $\begin{array}{l}\text { Hahn et al. } \\
\quad(1992)\end{array}$ \\
\hline $\begin{array}{l}\text { EUB338 } \\
\text { NON338 }\end{array}$ & $\begin{array}{c}46^{\circ} \mathrm{C} \\
1 \mathrm{~h} 30 \mathrm{~min}\end{array}$ & $\begin{array}{l}0,9 \mathrm{M} \mathrm{NaCl}, \\
20 \mathrm{mM} \text { Tris-HCl} \\
(\mathrm{pH} \mathrm{7,2}), 10 \mathrm{mM} \\
\text { EDTA, } 0,01 \% \\
\text { SDS + } 20 \% \\
\text { formamida }\end{array}$ & $\begin{array}{c}48^{\circ} \mathrm{C} \\
15 \mathrm{~min}\end{array}$ & $\begin{array}{lr}20 \mathrm{mM} & \text { Tris- } \\
\mathrm{HCl}(\mathrm{pH} & 7,2), \\
10 \mathrm{mM} & \text { EDTA, } \\
0,01 \% & \text { SDS } \\
\mathrm{com} 225 & \mathrm{mM} \\
\mathrm{NaCl} & \end{array}$ & Abe (1998) \\
\hline
\end{tabular}

As amostras foram examinadas em microscópio Olympus BX60, usando filtros específicos, com excitação na região ultravioleta (UV) do espectro, para a observação das células coradas com DAPI (4', 6-diadimino-2-fenil indol), e com excitação na região verde do espectro, para as células hibridadas com sondas marcadas com rodamina ou CY3. Foram capturadas três imagens do mesmo campo microscópico: em contraste de fase, referente à excitação do DAPI (correspondente ao total de células) e com excitação da marcação com rodamina ou CY3 (referente às células hibridadas). Quantificou-se o total de células coradas com DAPI e com a sonda específica, sendo utilizadas imagens em contraste de fase para diferenciar células coradas de partículas abióticas. As imagens dos campos microscópicos foram segmentadas e contadas no software daime 1.3.1 (DAIMS et al., 2006). Calculou-se a porcentagem de células hibridadas em relação ao número total de células coradas com DAPI em cada campo. A partir dos valores obtidos em cerca de 10 a 15 campos com magnificação 2.000X por amostra, determinou-se a média e erro padrão. 


\subsubsection{PCR-DGGE}

Analisou-se a comunidade microbiana pela técnica de reação de polimerização em cadeia - eletroforese em gel de gradiente desnaturante (polymerase chain reaction denaturing gradient gel electrophoresis: PCR-DGGE). As amostras foram coletadas e lavadas sucessivamente em tampão fosfato e centrifugada. Os pellets foram armazenados a $-20^{\circ} \mathrm{C}$. A extração do DNA dos pellets, foi baseada em protocolo de Griffiths et al. (2000) modificado, usando fenol tamponado com Tris e clorofórmio.

Na PCR foram usados iniciadores 968f-GC e 1392r para o domínio Bacteria (NIELSEN et al., 1999), e iniciadores 1100f-GC e 1400r para o domínio Archaea (KUDO et $a l .$, 1997). A PCR foi realizada em termociclador Eppendorf Mastercycler (Eppendorf AG 22331 Hamburg) nas condições descritas na Tabela 4.12.

Tabela 4.12: Condições utilizadas na PCR para o domínio Archaea e Bacteria

\begin{tabular}{cccccccc}
\hline \multirow{2}{*}{ Domínio } & $\begin{array}{c}\text { Pré } \\
\text { Desnatu- } \\
\text { ração }\end{array}$ & $\begin{array}{c}\mathrm{N}^{\mathrm{o}} \text { de } \\
\text { Ciclos }\end{array}$ & $\begin{array}{c}\text { Desnatu- } \\
\text { ração }\end{array}$ & $\begin{array}{c}\text { Anela- } \\
\text { mento }\end{array}$ & $\begin{array}{c}\text { Exten- } \\
\text { são }\end{array}$ & $\begin{array}{c}\text { Final de } \\
\text { Extensão }\end{array}$ & $\begin{array}{c}\text { Resfria- } \\
\text { mento }\end{array}$ \\
\hline \multirow{2}{*}{ Archaea } & $94^{\circ} \mathrm{C}$ & 35 & $94^{\circ} \mathrm{C}$ & $55^{\circ} \mathrm{C}$ & $72^{\circ} \mathrm{C}$ & $72^{\circ} \mathrm{C}$ & $4^{\circ} \mathrm{C}$ \\
& $90 \mathrm{~s}$ & - & $30 \mathrm{~s}$ & $30 \mathrm{~s}$ & $90 \mathrm{~s}$ & $180 \mathrm{~s}$ & \\
\hline \multirow{2}{*}{ Bacteria } & $94^{\circ} \mathrm{C}$ & 30 & $94^{\circ} \mathrm{C}$ & $38^{\circ} \mathrm{C}$ & $72^{\circ} \mathrm{C}$ & $72^{\circ} \mathrm{C}$ & $4{ }^{\circ} \mathrm{C}$ \\
& $5 \mathrm{~min}$ & - & $45 \mathrm{~s}$ & $45 \mathrm{~s}$ & $60 \mathrm{~s}$ & $5 \mathrm{~min}$ & \\
\hline
\end{tabular}

Os produtos da PCR foram aplicados em gel de poliacrilamida 8\% (massa/volume), em TAE 1X, com gradiente linear de desnaturante (ureia e formamida) variando de 45 a $65 \%$. A eletroforese foi realizada em voltagem constante de $75 \mathrm{~V}$ e temperatura de $60{ }^{\circ} \mathrm{C}$, durante 16 h. A imagem do gel foi capturada em equipamento Eagle Eye II (Stratagene, La Jolla, CA, USA) com iluminação UV. O perfil de DGGE foi analisado no software Bionumerics 2.5. Os coeficientes de similaridade e dendrograma foram determinados usando o coeficiente de Dice 
e algoritmo UPGMA (unweighted pair group method with arithmetic averages), respectivamente.

\subsubsection{Pirosequenciamento}

Em virtude da maior eficiência de degradação de LAS obtida nos diferentes ensaios no reator UASB (item 5.4.2), decidiu-se pela análise de pirosequenciamento das amostras da Parte 1 com água residuária de lavanderia. Quatro amostras foram coletadas: da manta de lodo $\left(\mathrm{ML}-\mathrm{R}_{\mathrm{L} 1}\right)$ e biomassa do separador de fases $\left(\mathrm{SF}-\mathrm{R}_{\mathrm{L} 1}\right)$ do reator alimentado com água de lavanderia $\left(\mathrm{R}_{\mathrm{L} 1}\right)$, e da manta de lodo $\left(\mathrm{ML}-\mathrm{R}_{\mathrm{S} 1}\right)$ e biomassa do separador de fases $\left(\mathrm{SF}-\mathrm{R}_{\mathrm{S} 1}\right)$ do reator alimentado com água residuária sintética $\left(\mathrm{R}_{\mathrm{S} 1}\right)$. Essas amostras foram analisadas mediante pirosequenciamento da região V3 do RNAr 16S.

As amostras foram lavadas sucessivamente em tampão fosfato e centrifugadas. Os pellets foram armazenados a $-20^{\circ} \mathrm{C}$. A extração do DNA dos pellets foi baseada em protocolo de Griffiths et al. (2000) modificado, usando fenol tamponado com Tris e clorofórmio.

O DNA extraído $(1 \mu \mathrm{L})$ foi quantificado em espectrofotômetro Nanodrop 2000. A integridade do DNA extraído foi verificada por eletroforese em gel de agarose $0,8 \%$ em TAE 1X. As amostras foram enviadas em concentração de no mínimo $10 \mathrm{ng} / \mu \mathrm{L}$ e pureza OD260/280 de no mínimo 1,8. Além disso, foi verificada a amplificação do DNA utilizando os iniciadores 27f e 1100r (LANE, 1991; TURNER et al., 1999). A PCR foi realizada em termociclador Eppendorf Mastercycler (Eppendorf AG - 22331 Hamburg) nas condições descritas na Tabela 4.13 usando as soluções descritas na Tabela 4.14. 
Tabela 4.13: Condições utilizadas na PCR

\begin{tabular}{ccccccc}
\hline $\begin{array}{c}\mathrm{N}^{\mathrm{o}} \text { de } \\
\text { Ciclos }\end{array}$ & $\begin{array}{c}\text { Pré Desnatu- } \\
\text { ração }\end{array}$ & $\begin{array}{c}\text { Desnatu- } \\
\text { ração }\end{array}$ & $\begin{array}{c}\text { Anela- } \\
\text { mento }\end{array}$ & $\begin{array}{c}\text { Exten- } \\
\text { são }\end{array}$ & $\begin{array}{c}\text { Final de } \\
\text { Extensão }\end{array}$ & $\begin{array}{c}\text { Resfria- } \\
\text { mento }\end{array}$ \\
\hline \multirow{2}{*}{30} & $94^{\circ} \mathrm{C}$ & $94^{\circ} \mathrm{C}$ & $55^{\circ} \mathrm{C}$ & $72^{\circ} \mathrm{C}$ & $72^{\circ} \mathrm{C}$ & $4^{\circ} \mathrm{C}$ \\
& $5 \mathrm{~min}$ & $45 \mathrm{~s}$ & $45 \mathrm{~s}$ & $105 \mathrm{~s}$ & $105 \mathrm{~s}$ & \\
\hline
\end{tabular}

Tabela 4.14: Soluções para amplificação usando iniciadores 27f e 1100r

\begin{tabular}{lcc}
\hline Reagentes & Concentração & $\begin{array}{c}\text { Quantidade por amostra } \\
(\mu \mathrm{L})\end{array}$ \\
\hline $\mathrm{H}_{2} \mathrm{O}$ ultrapura & - & 3,0 \\
Tampão PCR Invitrogen ${ }^{\circledR}$ & $10 \mathrm{X}$ & 5,0 \\
$\mathrm{MgCl}_{2}$ & $50 \mathrm{mM}$ & 1,5 \\
$\mathrm{dNTP}$ (cada base nitrogenada) & $2 \mathrm{mM}$ & 5,0 \\
Iniciador 27f & $100 \mathrm{pmol} / \mu \mathrm{L}$ & 0,5 \\
Iniciador 1100r & $100 \mathrm{pmol} / \mu \mathrm{L}$ & 0,5 \\
Taq DNA Polimerase Invitrogen ${ }^{\circledR}$ & $5 \mathrm{U} / \mu \mathrm{L}$ & 0,5 \\
Amostra & $100 \mathrm{ng}$ & 2,0 \\
\hline
\end{tabular}

O DNA extraído foi purificado usando o kit Illustra GFX PCR DNA and Gel Band Purification (GE Healthcare) de acordo com as especificações detalhadas no manual do kit. Após purificação, o DNA extraído foi desidratado em etanol $95 \%$ e enviado para o Instituto de Agrobiotecnologia Rosario (INDEAR) para análise de pirosequenciamento em equipamento 454 GS-FLX (Life Sciences, Roche). Foram usados quatro barcodes com 10 pb, além dos tag e iniciadores designados para cada amostra (Tabela 4.15). As amostras foram agrupadas em quantias equimolares, em concentração de $9,92 \times 10^{6}$ moléculas de $\mathrm{DNA} / \mu \mathrm{L}$ (tamanho dos amplicons: $336 \mathrm{pb}$ ). Em seguida, as amostras foram combinadas com 9,92 milhões de microesferas magnéticas (beads) e amplificadas por meio de PCR em emulsão (MARGULIES et al., 2005). As microesferas ligadas aos fragmentos de DNA foram depositadas em distintos poços, ocupando 1/4 de placa de sequenciamento. Ressalta-se essa placa de sequenciamento foi composta por 19 amostras, das quais quatro amostras foram analisadas para o presente trabalho enquanto as demais se referiam a estudos não relacionados. 
Tabela 4.15: Barcode de referências das amostras da manta de lodo (ML) e biomassa do separador de fases (SF) dos reatores $\mathrm{R}_{\mathrm{L} 1}$ e $\mathrm{R}_{\mathrm{S} 1}$

\begin{tabular}{|c|c|c|c|}
\hline Amostra & Barcode & Tag+ Iniciador Forward & Iniciador Reverse \\
\hline $\mathrm{ML}-\mathrm{R}_{\mathrm{L} 1}$ & CGACGTGACT & $\begin{array}{l}\text { CACGACGTTGTAAAACGACAYT } \\
\text { GGGYDTAAAGNG }\end{array}$ & $\begin{array}{l}\text { CAGGAAACAGCTA } \\
\text { TGACC }\end{array}$ \\
\hline SF-R ${ }_{\text {L1 }}$ & $\mathrm{T} A$ & $\begin{array}{l}\text { CACGACGTTGTAAAACGACAYT } \\
\text { GGGYDTAAAGNG }\end{array}$ & $\begin{array}{l}\text { CAGGAAACAGCTA } \\
\text { TGACC }\end{array}$ \\
\hline $\mathrm{ML}_{\mathrm{L} 1}$ & CGTGAT & $\begin{array}{l}\text { CACGACGTTGTAAAACGACAYT } \\
\text { GGGYDTAAAGNG }\end{array}$ & $\begin{array}{l}\text { CAGGAAACAGCTA } \\
\text { TGACC }\end{array}$ \\
\hline $\mathrm{SF}-\mathrm{R}_{\mathrm{S} 1}$ & TACAGATCGT & $\begin{array}{l}\text { CACGACGTTGTAAAACGACAYT } \\
\text { GGGYDTAAAGNG }\end{array}$ & $\begin{array}{l}\text { CAGGAAACAGCTA } \\
\text { TGACC }\end{array}$ \\
\hline
\end{tabular}

Os dados obtidos pelo pirosequenciamento foram analisados por meio do software QIIME (Quantitative Insights Into Microbial Ecology; CAPORASO et al., 2010a) para obtenção de dados estatísticos das amostras. O primeiro passo foi selecionar as sequências adotando os seguintes parâmetros: comprimento maior ou igual a 200 pb; e coeficiente de qualidade maior ou igual a 25 . Dentre as sequências restantes, foram selecionadas somente as que possuíam o começo do barcode especificado na Tabela 4.15, com uma tolerância de até duas bases - uma vez identificado, o barcode foi removido da sequência. Dessas sequências selecionadas, identificou-se o começo do iniciador forward (neste caso composto por tag+ iniciador forward), que foi removido tolerando nesse caso até três substituições na sequência. Nas sequências do passo anterior, procedeu-se a busca e remoção do iniciador reverse no final das sequências - caso não fosse encontrado se removeu apenas o tag. Finalmente, foram removidas as sequências que apresentaram homopolímeros de tamanho maior ou igual a seis e/ou ao menos uma base ambígua.

Para a determinação das unidades taxonômicas operacionais (UTO) foi utilizado o método UClust (EDGAR, 2010), com 97\% de similaridade. Em seguida, foram selecionadas as sequências representativas de cada UTO, que foram definidas pelo software QIIME (a descrição do processo de seleção das sequências representativas encontra-se em: http://qiime.org/scripts/pick_rep_set.html). 
As sequências representativas de cada UTO foram alinhadas usando o PyNast (CAPORASO et al., 2010b) e elaborou-se a árvore filogenética usando o FastTree (PRICE et al., 2009).

Para a classificação taxonômica das UTOs utilizou-se o RDP-Classifier (Ribossomal Database Project; http://rdp.cme.msu.edu/), adotando limite de confiança de 0,5. Para limite de confiança maior ou igual a 0,5 , observou-se similaridades maiores que $95 \%$ na região V3 do RNAr 16S (CLAESSON et al., 2009).

As medidas de diversidade alfa e beta também foram calculadas no software QIIME. As medidas de diversidade alfa determinadas foram os índices de Chao1, Shannon, dominância e equitabilidade. Os índices de Chao1, dominância e equitabilidade foram determinados por meio do software QIIME, e o índice de Shannon foi determinado utilizando a ferramenta do RDP-Pyrosequencing Pypeline (http://pyro.cme.msu.edu/). Além disso, foram quantificadas as UTOs com apenas uma ou duas sequências (UTOs simples e duplas). A curva de rarefação das amostras foi determinada usando a ferramenta de análise do RDPPyrosequencing Pypeline (http://pyro.cme.msu.edu/). Foram determinadas as seguintes medidas de diversidade beta: Bray-Curtis, UniFrac não ponderado e UniFrac ponderado. As medidas de diversidade beta foram calculadas usando a técnica de jackknife, que consiste na reamostragem de um subconjunto de dados de cada amostra. O tamanho do subconjunto foi determinado como $75 \%$ do tamanho da amostra menor. 


\section{RESULTADOS E DISCUSSÃO}

\subsection{Determinação de isoterma de adsorção de LAS}

Os dados de adsorção de LAS ao lodo granulado foram ajustados à equação de Freundlich (Eq. 4.1; p. 22) e de Langmuir (Eq. 4.3; p. 23), sendo observado maior coeficiente de determinação $\left(\mathrm{R}^{2}\right)$ no ajuste à equação de Freundlich (Figura 5.1; Tabela 5.1).

Tabela 5.1: Ajuste dos dados de adsorção de LAS ao lodo granulado às equações de Freundlich e Langmuir

\begin{tabular}{lccc}
\hline Equação & & & $\mathrm{R}^{2}$ \\
\hline Freundlich & $q=1,15 \times C^{0,81}$, & $K_{f}: 1,15 \mathrm{~L} / \mathrm{g} \mathrm{ST} ; 1 / n: 0,81$ & 0,9618 \\
Langmuir & $q=\frac{10,6 \times 0,131 \times C}{1+0,131 \times C}$, & $b: 0,131 ; q_{\text {max }}: 10,6 \mathrm{mg}$ LAS/g ST & 0,5544 \\
\hline
\end{tabular}

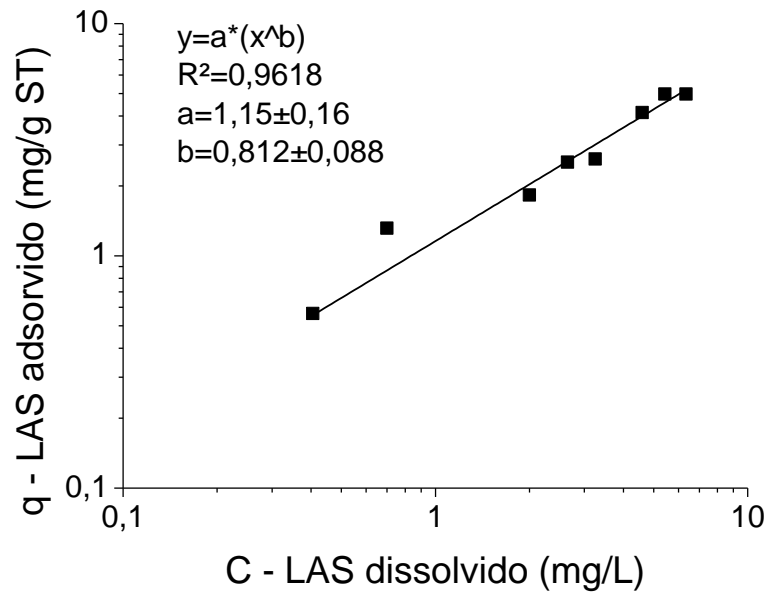

(a)

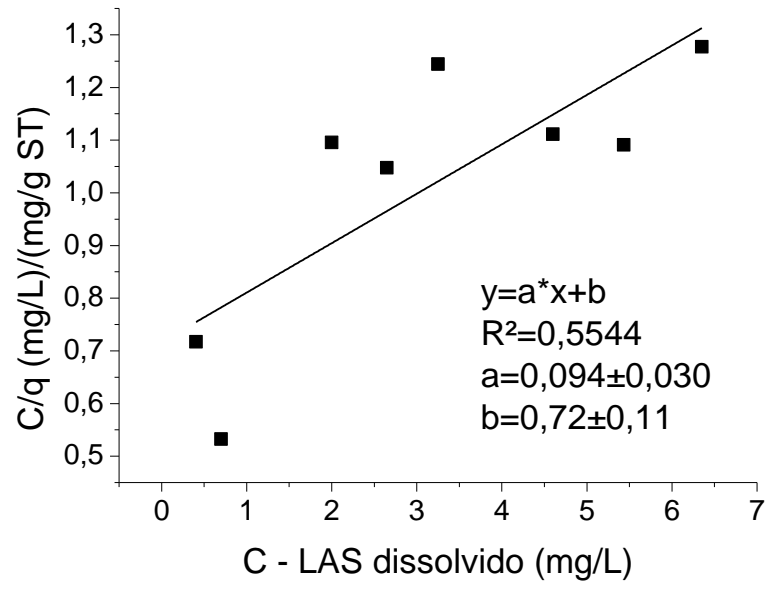

(b)

Figura 5.1: Isoterma de Freundlich (a) e Langmuir (b) para adsorção de LAS ao lodo granulado 
A equação de Freundlich pressupõe que a adsorção decresce logaritmicamente à medida que a superfície é coberta pelo soluto (LAS). Portanto, a adsorção de LAS ao lodo granulado torna-se mais difícil à medida que os sítios de adsorção são preenchidos.

Em lodos anaeróbios, observou-se coeficiente de adsorção $\left(K_{f}\right)$ entre 0,796 e 3,24 L/g, e ordem de potência 1/n entre 0,35 e 0,92 (MOGENSEN et al., 2003; GARCIA et al., 2006a). O coeficiente de adsorção $\left(K_{f}=1,15 \mathrm{~L} / \mathrm{g}\right)$ e a ordem de potência $1 / n(0,81)$ obtidos no presente trabalho estavam dentro dessa faixa de valores. Atribuiu-se a diferença em relação ao maior coeficiente de adsorção, ou seja, de 3,24 L/g (GARCIA et al., 2006a), à maior parcela de homólogo $\mathrm{C}_{13}$, além da presença do homólogo $\mathrm{C}_{14}$ na mistura comercial de LAS usada pelos autores. No estudo de Garcia et al. (2006a), utilizou-se uma mistura comercial (Petresa) composta pelos homólogos $\mathrm{C}_{10}(12,8 \%), \mathrm{C}_{11}(33,7 \%), \mathrm{C}_{12}(29,8 \%), \mathrm{C}_{13}(23,0 \%)$ e $\mathrm{C}_{14}(0,7 \%)$. No presente estudo, foi utilizada uma mistura comercial (Aldrich), nesse caso composta pelos homólogos $\mathrm{C}_{10}(15,24 \%), \mathrm{C}_{11}(38,96 \%), \mathrm{C}_{12}(32,89 \%)$ e $\mathrm{C}_{13}(12,91 \%)$ (PAKOU et al., 2009). Em virtude do aumento da adsorção de LAS para homólogos com maior cadeia alquílica (HAND e WILLIAMS, 1987; WESTALL et al., 1999; GARCIA et al., 2002), observou-se menor coeficiente de adsorção $\left(K_{f}=1,15 \mathrm{~L} / \mathrm{g}\right)$ no presente trabalho, quando comparado com o coeficiente obtido por Garcia et al. (2006a) $\left(K_{f}=3,24 \mathrm{~L} / \mathrm{g}\right)$. No presente trabalho observou-se maior proporção dos homólogos $\mathrm{C}_{10}(15,24 \%), \mathrm{C}_{11}(38,96 \%)$ e $\mathrm{C}_{12}(32,89 \%)$, e menor proporção do homólogo $\mathrm{C}_{13}(12,91 \%)$ que no trabalho de Garcia et al. (2006a) $\left(\mathrm{C}_{10}: 12,8 \%\right.$; $\mathrm{C}_{11}: 33,7 \% ; \mathrm{C}_{12}: 29,8 \% ; \mathrm{C}_{13}: 23,0 \%$; e $\left.\mathrm{C}_{14}: 0,7 \%\right)$ 


\subsection{Degradação de LAS em reator UASB com diferentes co-substratos}

Em relação ao pH (em torno de 7,2-7,6), alcalinidade (alcalinidade total efluente: 290$\left.364 \mathrm{mg} \mathrm{CaCO}_{3} / \mathrm{L}\right)$, sulfato (0,6-1,0 mg S/L) e sulfeto (0,5-1,0 mg S/L) efluente, foi observada pouca variação (Tabela 5.2), independente das diferentes condições aplicadas para cada etapa operacional (Etapas I a V). 
Tabela 5.2: Médias e desvios padrão dos parâmetros analisados no reator $\mathrm{R}_{\mathrm{UASB}}$

\begin{tabular}{|c|c|c|c|c|c|}
\hline Parâmetro & I & II & III & IV & $\mathrm{V}$ \\
\hline \multicolumn{6}{|l|}{ Ácidos orgânicos voláteis (mg/L) } \\
\hline \multicolumn{6}{|l|}{ Afluente } \\
\hline Acético & - & $17 \pm 17$ & $30 \pm 30$ & $17 \pm 11$ & $37 \pm 7$ \\
\hline Propiônico & - & ND & ND & ND & ND \\
\hline \multicolumn{6}{|l|}{ Efluente } \\
\hline Acético & $8 \pm 3$ & $20 \pm 14$ & $21 \pm 13$ & $19 \pm 19$ & $11 \pm 7$ \\
\hline Propiônico & ND & $0,3 \pm 1,5$ & ND & $1 \pm 4$ & ND \\
\hline \multicolumn{6}{|l|}{ Alcalinidade $\left(\mathrm{mg} \mathrm{CaCO}_{3} / \mathrm{L}\right)$} \\
\hline \multicolumn{6}{|l|}{ Afluente } \\
\hline Parcial & $252 \pm 11$ & $259 \pm 19$ & $252 \pm 8$ & $256 \pm 20$ & $263 \pm 17$ \\
\hline Total & $307 \pm 10$ & $328 \pm 22$ & $325 \pm 9$ & $329 \pm 12$ & $348 \pm 24$ \\
\hline \multicolumn{6}{|l|}{ Efluente } \\
\hline Parcial & $222 \pm 13$ & $225 \pm 20$ & $208 \pm 19$ & $229 \pm 32$ & $268 \pm 20$ \\
\hline Total & $291 \pm 8$ & $303 \pm 19$ & $291 \pm 7$ & $310 \pm 29$ & $364 \pm 29$ \\
\hline \multicolumn{6}{|l|}{ Biomassa no reator $(\mathrm{g} / \mathrm{L})$} \\
\hline ST & $7,7 \pm 0,5$ & $5,7 \pm 0,6$ & - & $4,6 \pm 0,5$ & $4,5 \pm 0,5$ \\
\hline STV & $6,4 \pm 0,4$ & $4,5 \pm 0,5$ & - & $3,6 \pm 0,4$ & $3,2 \pm 0,4$ \\
\hline STF & $1,3 \pm 0,2$ & $1,2 \pm 0,2$ & - & $1,0 \pm 0,3$ & $1,3 \pm 0,2$ \\
\hline \multicolumn{6}{|l|}{ DQO } \\
\hline Afluente (mg/L) & $869 \pm 103$ & $1155 \pm 121$ & $951 \pm 142$ & $286 \pm 232$ & $570 \pm 161$ \\
\hline Efluente (mg/L) & $79 \pm 20$ & $126 \pm 59$ & $104 \pm 42$ & $65 \pm 58$ & $55 \pm 16$ \\
\hline Remoção $(\%)$ & $91 \pm 3$ & $89 \pm 5$ & $89 \pm 3$ & $75 \pm 22$ & $90 \pm 2$ \\
\hline $\begin{array}{l}\text { Carga orgânica específica } \\
\text { (g DQO/g STV.d) }\end{array}$ & $0,14 \pm 0,01$ & $0,21 \pm 0,04$ & $0,21 \pm 0,04$ & $0,06 \pm 0,05$ & $0,18 \pm 0,05$ \\
\hline $\begin{array}{l}\text { Taxa de carregamento orgânico } \\
\left(\mathrm{kg} \text { DQO } / \mathrm{m}^{3} \cdot \mathrm{d}\right)\end{array}$ & $0,9 \pm 0,1$ & $1,2 \pm 0,1$ & $0,9 \pm 0,2$ & $0,3 \pm 0,2$ & $0,6 \pm 0,2$ \\
\hline \multicolumn{6}{|l|}{$\mathrm{pH}$} \\
\hline Afluente & $7,6 \pm 0,1$ & $7,6 \pm 0,1$ & $7,5 \pm 0,1$ & $7,5 \pm 0,1$ & $7,5 \pm 0,1$ \\
\hline Efluente & $7,2 \pm 0,2$ & $7,2 \pm 0,1$ & $7,2 \pm 0,2$ & $7,4 \pm 0,1$ & $7,3 \pm 0,1$ \\
\hline Recirculação de efluente & - & - & $\operatorname{sim}$ & $\operatorname{sim}$ & $\operatorname{sim}$ \\
\hline \multicolumn{6}{|l|}{ LAS } \\
\hline Afluente (mg/L) & - & $14 \pm 1$ & $14 \pm 1$ & $14 \pm 1$ & $14 \pm 1$ \\
\hline Efluente (mg/L) & - & $8 \pm 2$ & $9 \pm 2$ & $10 \pm 2$ & $7 \pm 1$ \\
\hline Remoção (\%) & - & $41 \pm 18$ & $41 \pm 9$ & $31 \pm 15$ & $50 \pm 10$ \\
\hline SST efluente (mg/L) & $30 \pm 10$ & $44 \pm 8$ & $31 \pm 9$ & $54 \pm 8$ & $67 \pm 9$ \\
\hline Sulfato efluente (mg S/L) & - & $0,8 \pm 0,5$ & $1,0 \pm 0,7$ & $0,7 \pm 0,2$ & $0,6 \pm 0,2$ \\
\hline Sulfeto efluente (mg S/L) & - & $0,5 \pm 0,2$ & $0,5 \pm 0,1$ & $0,6 \pm 0,1$ & $1,0 \pm 0,3$ \\
\hline Duração da etapa (d) & 30 & 140 & 26 & 51 & 44 \\
\hline
\end{tabular}

ND: Não detectado.

A remoção de DQO foi alta, cerca de $90 \%$ na maior parte da operação, com exceção da Etapa IV (redução para 75\%) devido à aeração da água de abastecimento (Tabela 5.2). Após a aeração da água de abastecimento (Etapa IV) foi necessário maior período para 
recuperação da atividade de remoção de DQO (31 dias; entre o $203^{\circ}$ e o $234^{\circ}$ dia de operação). Além disso, a adição de metanol no início da Etapa II provocou a redução da eficiência de remoção de DQO por sete dias (entre o $38^{\circ}$ e o $45^{\circ}$ dia de operação) (Figura 5.2), em virtude da adaptação dos microrganismos à fonte adicionada.

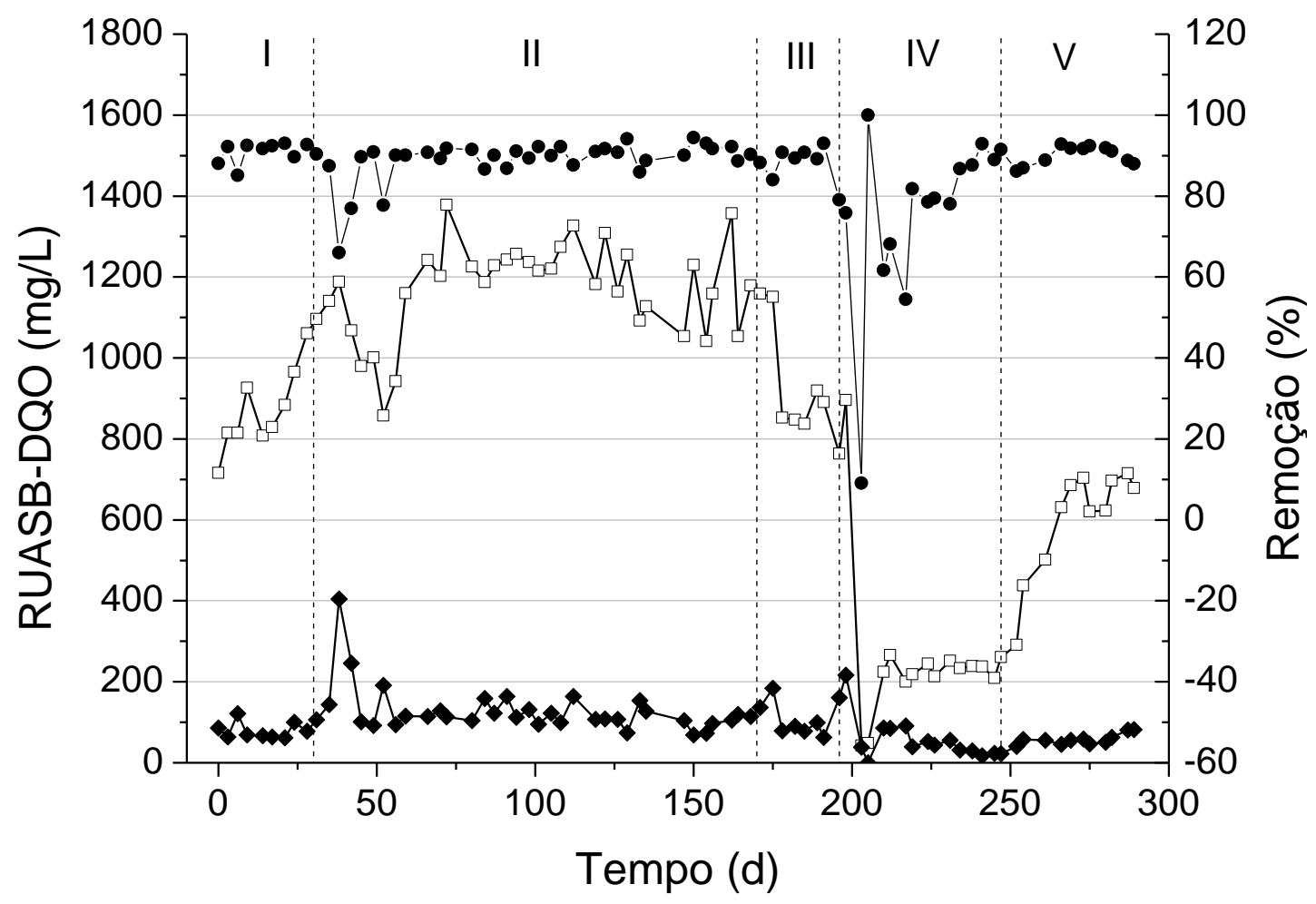

Figura 5.2: Variação temporal de DQO afluente $(\square)$, efluente $(\bullet)$ e remoção $(\bullet)$ no reator $\mathrm{R}_{\mathrm{UASB}}$

Em virtude da adsorção de LAS ao lodo granulado, observou-se variação da eficiência de remoção de LAS entre 30 e $90 \%$ nos primeiros 68 dias da Etapa II (entre o $30^{\circ}$ e $98^{\circ}$ dia; Figura 5.3). A partir do $98^{\circ}$ dia de operação observou-se equilíbrio entre a adsorção e degradação de LAS no lodo granulado, sendo verificada eficiência de remoção de LAS média de $30 \pm 7 \%$ no período entre o $98^{\circ}$ dia de operação e o fim da Etapa II. Observou-se aumento

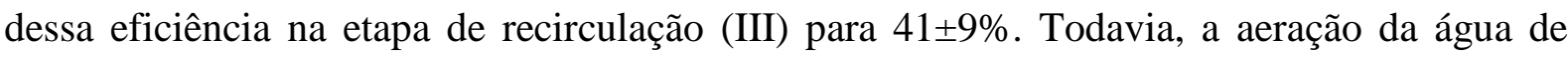
abastecimento provocou a redução da remoção de LAS para $31 \pm 15 \%$ na Etapa IV. Na última 
etapa (V), a adição de co-substrato complexo (extrato de levedura) resultou em maior remoção média de LAS $(50 \pm 10 \%)$.

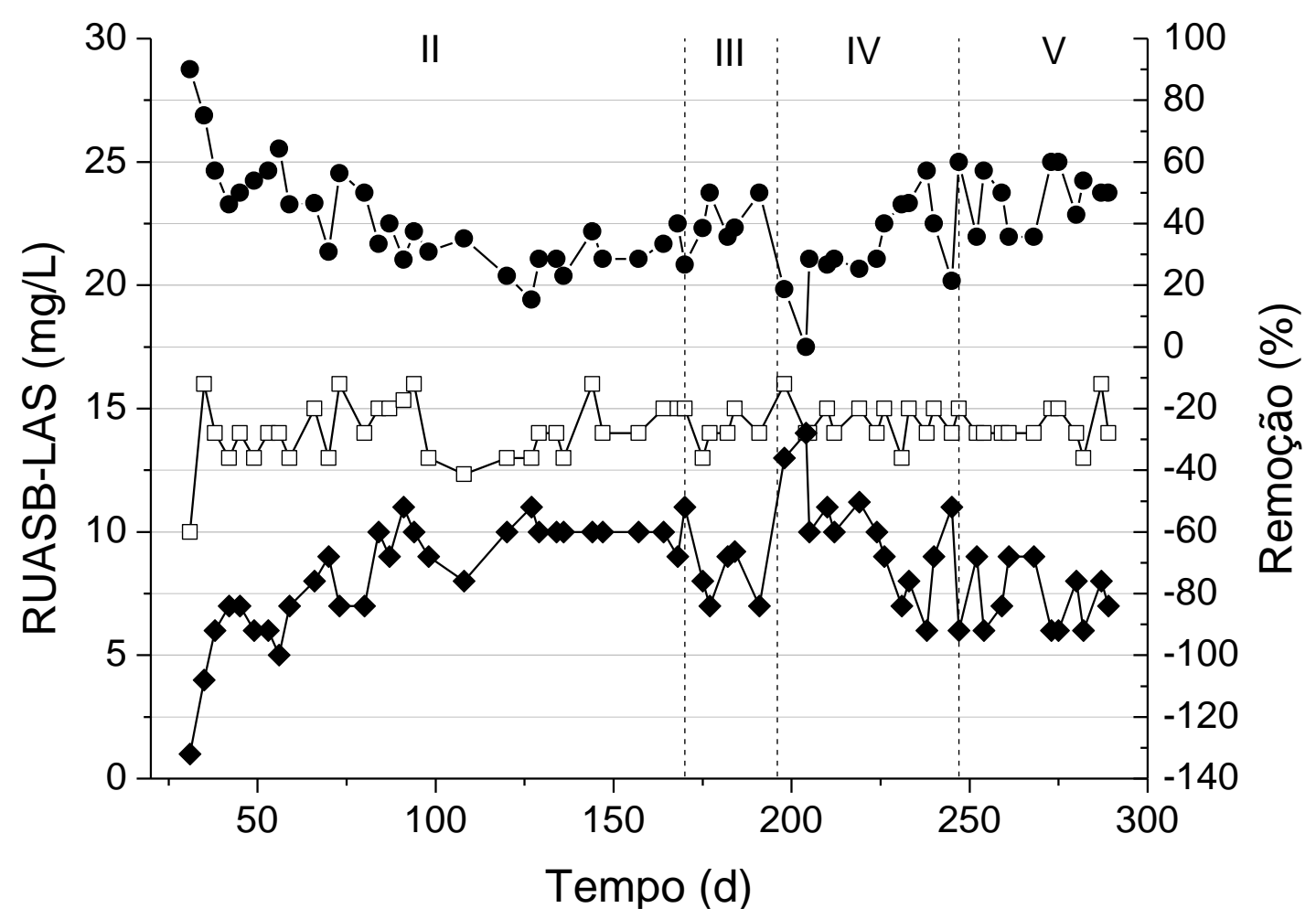

Figura 5.3: Variação temporal de LAS afluente $(\square)$, efluente $(\bullet)$ e remoção $(\bullet)$ no reator $\mathrm{R}_{\mathrm{UASB}}$

Observou-se aumento da concentração de ácido acético entre o $80^{\circ}$ e $112^{\circ}$ dia de operação, para valores entre 20 e $45 \mathrm{mg} / \mathrm{L}$ (Figura 5.4). Esse aumento foi relacionado com a adição de inóculo para reposição da biomassa suspensa (vide item 4.6.2, p. 25), uma vez que a presença de LAS pode aumentar a biodisponibilidade de outros compostos orgânicos aderidos ao lodo granulado (FU e ALEXANDER, 1995; GARCIA et al., 2006b). Essa possibilidade foi observada por Garcia et al. (2006b), pelo aumento da produção de biogás $\left(\mathrm{CH}_{4}\right.$ e $\left.\mathrm{CO}_{2}\right)$ na presença de LAS em concentrações menores que $25 \mathrm{mg} / \mathrm{L}$. 


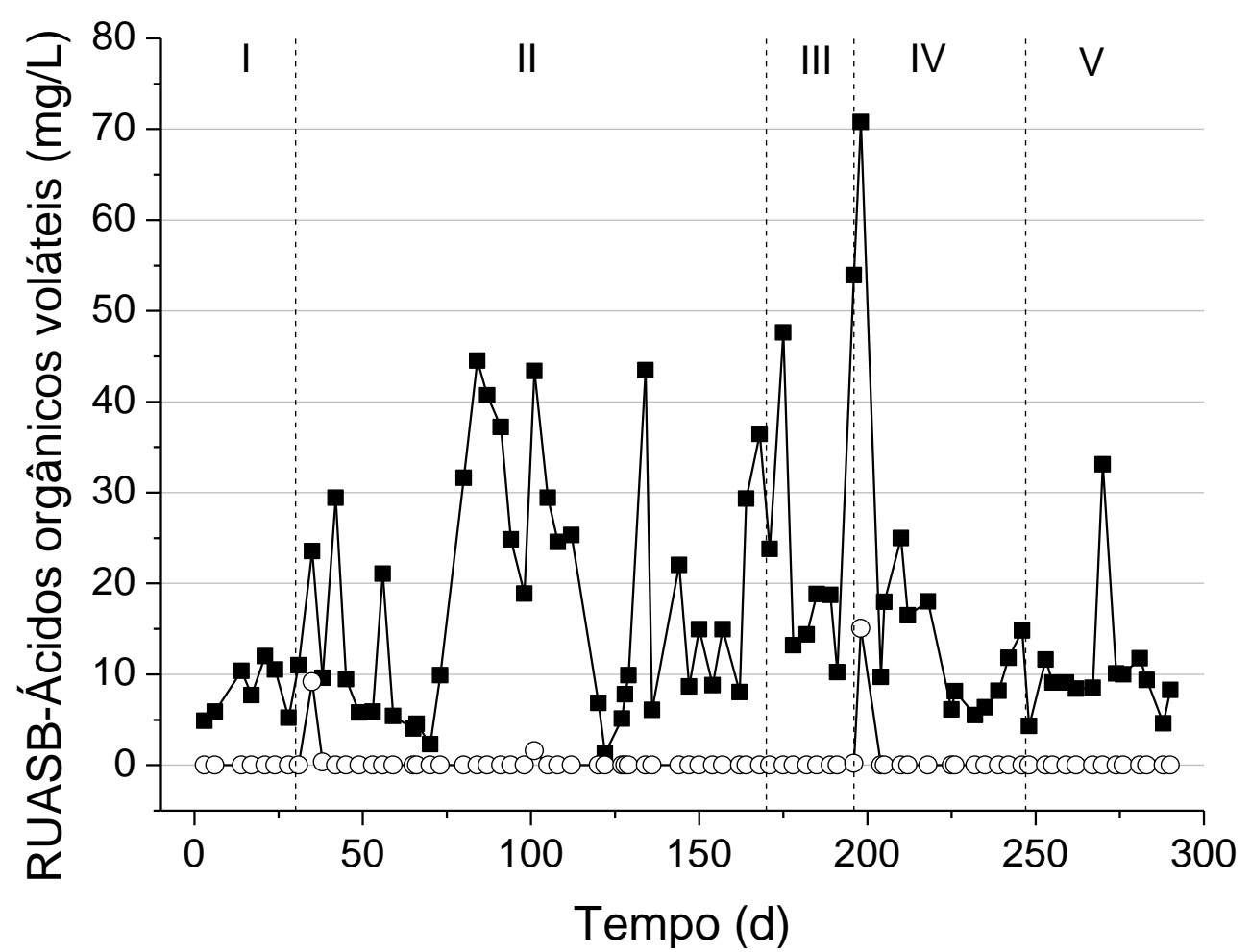

Figura 5.4: Variação temporal de ácido acético (a) e propiônico (o) no reator $\mathrm{R}_{\mathrm{UASB}}$

Em virtude da aeração da água de abastecimento (Etapa IV), observou-se aumento da concentração de ácido acético até $70 \mathrm{mg} / \mathrm{L}$ no efluente (Figura 5.4). Cabe ressaltar que as concentrações de ácidos voláteis da Etapa IV não foram maiores que nas demais etapas devido à redução de DQO afluente e à drenagem de parte da água residuária contida no reator UASB. Além disso, observou-se maior variação da relação alcalinidade intermediaria/parcial (AI/AP), de 0,26 a 0,68, entre o $198^{\circ}$ e $219^{\circ}$ dia de operação (Figura 5.5). Como consequência, tanto a remoção de DQO, quanto de LAS foram menores, cerca de $60 \%$ e $20 \%$, respectivamente (Figura 5.2 e Figura 5.3). 


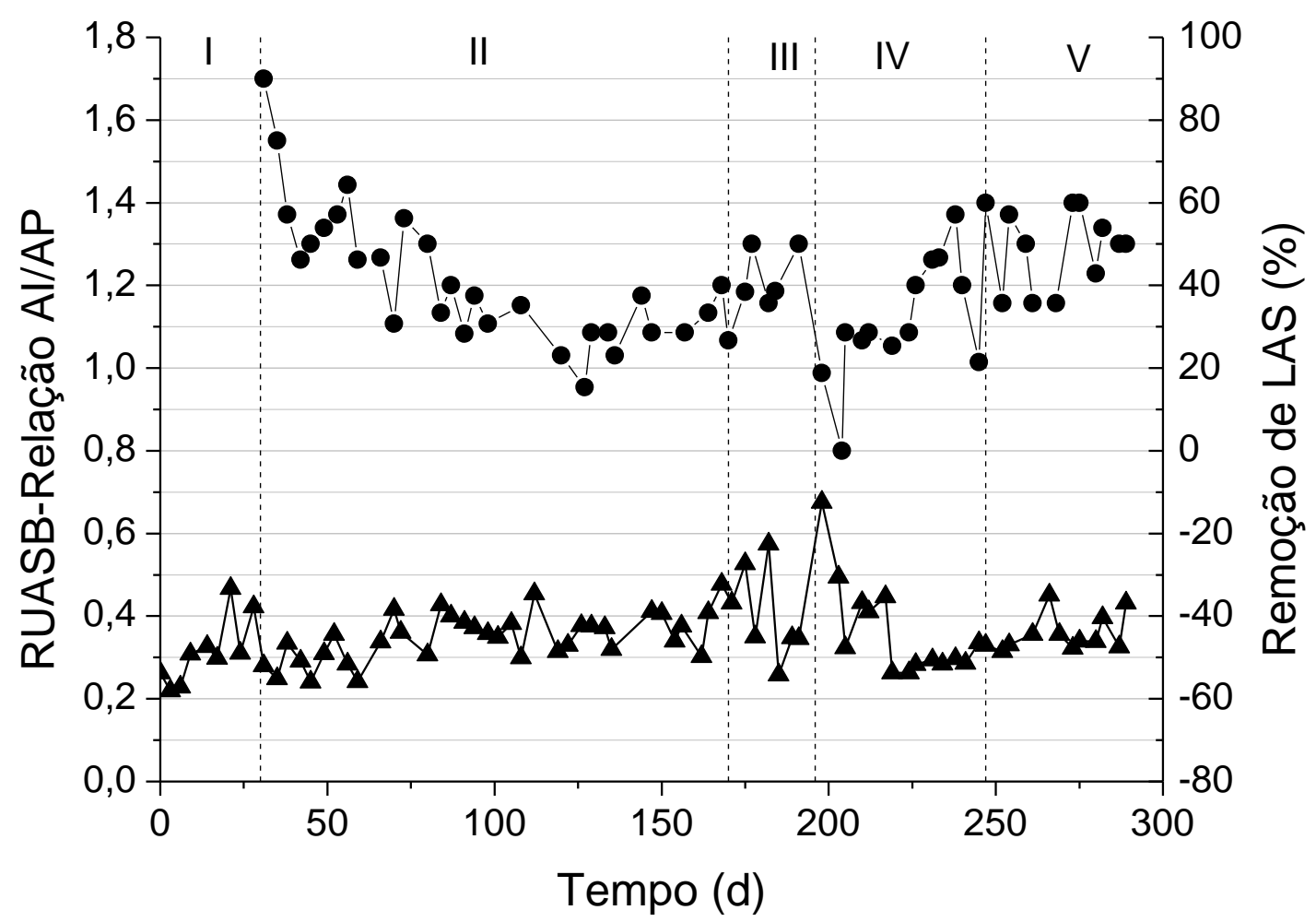

Figura 5.5: Variação temporal da remoção de LAS $(\bullet)$ e relação AI/AP $(\boldsymbol{\Delta})$ no reator $\mathrm{R}_{\mathrm{UASB}}$

Além do aumento da remoção de LAS para 50\% (Etapa V), devido à adição de cosubstrato complexo (extrato de levedura), observou-se aumento da estimativa de populações de arquéias metanogênicas e bactérias anaeróbias totais. A estimativa de populações de arquéias metanogênicas aumentou de $1,9 \times 10^{3}$ (Etapa II) para 4,4×10 $0^{7} \mathrm{NMP} / \mathrm{g} \mathrm{STV}$ (Etapa V), e de bactérias anaeróbias totais de $1,9 \times 10^{8}$ (Etapa II) para $3,8 \times 10^{11} \mathrm{NMP} / \mathrm{g} \mathrm{STV}$ (Etapa V). Entre as condições aplicadas entre as Etapas II e V, apenas a recirculação de efluente (Etapa III) e adição de extrato de levedura (V) poderiam ser relacionadas com o aumento da estimativa de populações de arquéias metanogênicas e bactérias anaeróbias totais. Todavia, no período de 77 dias das Etapas III e IV observou-se decréscimo da concentração da biomassa do reator, de 4,5 para 3,6 g STV/L (perda de $12 \mathrm{mg} \mathrm{STV/L.d),} \mathrm{enquanto,} \mathrm{na} \mathrm{Etapa} \mathrm{V,} \mathrm{a}$ redução da biomassa do reator foi menor, de 3,6 para 3,2 g STV/L em 44 dias (perda de 9 mg STV/L.d) (Tabela 5.2). Em virtude da menor perda de biomassa na Etapa V, atribuiu-se o aumento da estimativa do NMP à adição de extrato de levedura, que proporcionou aumento 
das fontes de carbono, nitrogênio, micronutrientes e vitaminas. A adição de co-substrato complexo (extrato de levedura) pode ter favorecido a formação de consórcios microbianos, necessários para degradação de LAS (JIMENEZ et al., 1991), além de fornecer os nutrientes necessários para manter a atividade de degradação do surfactante (KHLEIFAT, 2006a; ABBOUD et al., 2007) e micronutrientes, aminoácidos e vitaminas para crescimento das arquéias metanogênicas.

Ao final de toda operação do reator $\mathrm{R}_{\mathrm{UASB}}$, obteve-se eficiência de degradação de $29 \%$ segundo balanço de massa de LAS (Tabela 5.3). Para tanto, foi considerado todo LAS adicionado nas quatro etapas (total de $35.429 \mathrm{mg}$ ), descontado a parcela descartada pelo efluente nas quatro etapas (23.306 mg), e também subtraído a parcela adsorvida na biomassa ao final do ensaio $(2.016 \mathrm{mg})$. Por meio dos dados do balanço de massa determinou-se a carga específica de LAS e degradação específica, de 3,24 mg/g STV.d e 0,93 mg/g STV.d, respectivamente. No cálculo dessas taxas específicas considerou-se a média ponderada da concentração de sólidos voláteis do reator durante as etapas com LAS (II a V), que foi de 4,0 g STV/L.

Tabela 5.3: Balanço de massa de LAS do reator $\mathrm{R}_{\mathrm{UASB}}$

\begin{tabular}{lc}
\hline Balanço de massa & $\mathrm{R}_{\mathrm{UASB}}$ \\
\hline Adicionado (mg) & 35.429 \\
Adsorvido (mg) & 2.016 \\
Efluente (mg) & 23.306 \\
Degradado (mg) & 10.107 \\
Degradado (\%) & $29 \pm 12$ \\
Carga específica de LAS (mg LAS/g STV.d) & 3,24 \\
Degradação específica de LAS (mg LAS/g STV.d) & 0,93 \\
Duração (d) & 261 \\
\hline
\end{tabular}




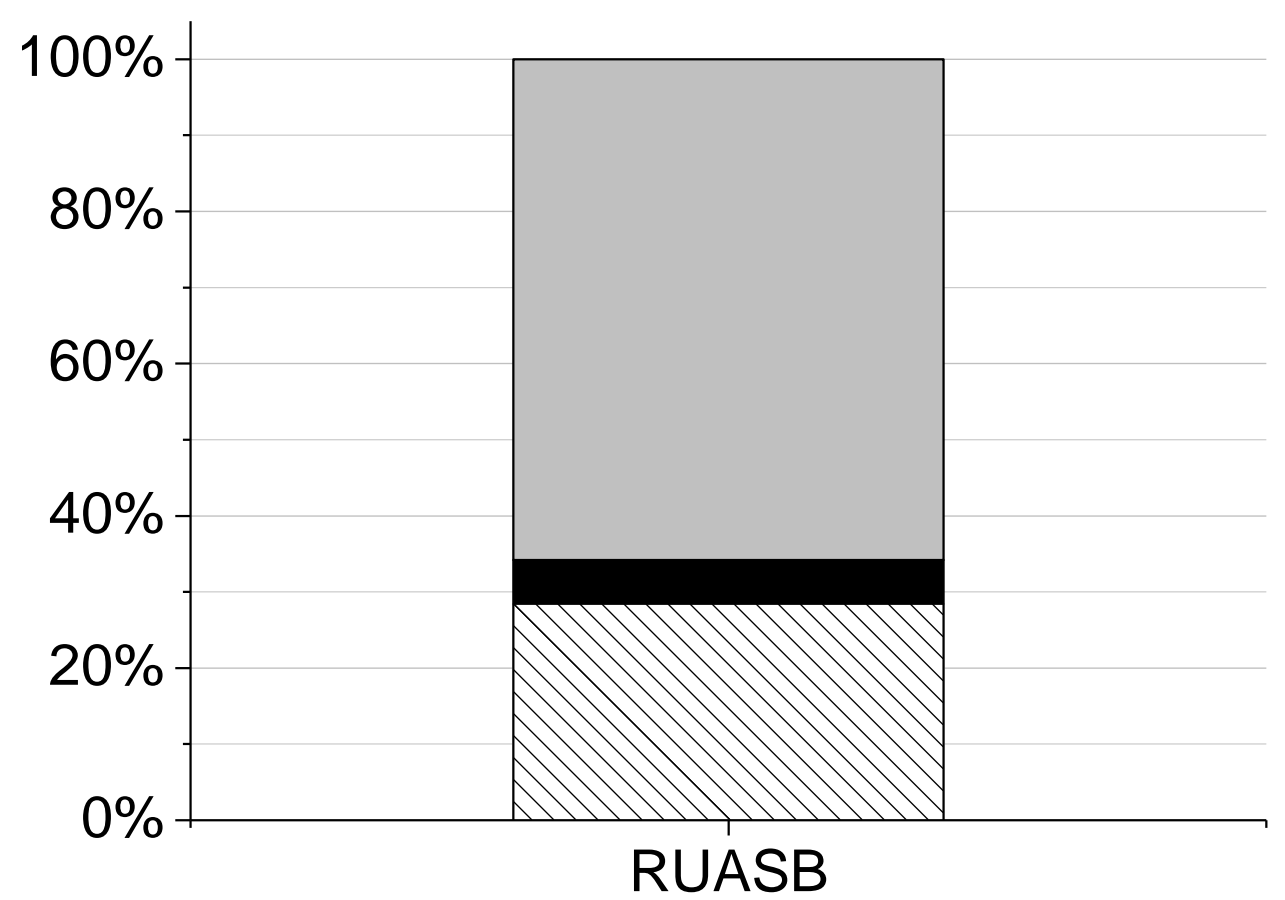

Figura 5.6: Distribuição do destino final de LAS no reator $\mathrm{R}_{\mathrm{UASB}}$ : efluente $(\square)$, adsorvido na biomassa $(\mathbf{\square})$ e degradado $(\mathbb{\mathbb { Q }})$

Essa eficiência de degradação foi menor que a relatada em reator UASB (50\%), em condição mesofílica $\left(37^{\circ} \mathrm{C}\right)$ e TDH de 48 h (LOBNER et al., 2005). Nesse caso, atribuiu-se a maior degradação ao TDH aplicado, induzindo o uso de LAS como fonte de carbono, após o consumo de substratos facilmente degradáveis. Além disso, há de se considerar a redução na eficiência de remoção de LAS devido à aeração da água de abastecimento (Etapa IV), que contribuiu para a menor degradação de surfactante no reator $\mathrm{R}_{\mathrm{UASB}}$.

\subsubsection{Granulometria}

Em relação ao diâmetro médio dos grânulos (Figura 5.7), observou-se pouca variação; ou seja, entre 2,9 e 3,6 mm para as diferentes condições experimentais relacionadas com cosubstratos, carga orgânica específica e taxa de carregamento orgânico (Figura 5.8). Observou- 
se diâmetro médio de $3,1 \pm 0,5 \mathrm{~mm}$ no inóculo. $\mathrm{O}$ menor valor $(2,9 \pm 0,4 \mathrm{~mm})$ foi observado ao final da Etapa I (900 mg DQO/L de etanol, 0,14 g DQO/g STV.d e 0,9 kg DQO/m³.d, sem LAS), enquanto, o maior diâmetro $(3,6 \pm 0,4 \mathrm{~mm})$ foi observado ao final da Etapa V (200 $\mathrm{mg}$ DQO /L de etanol, 200 mg DQO/L de metanol, $200 \mathrm{mg} / \mathrm{L}$ de extrato de levedura, $14 \mathrm{mg} / \mathrm{L}$

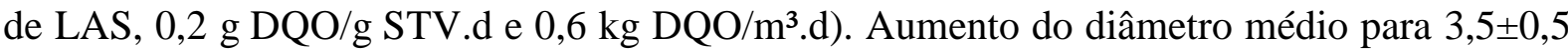
mm foi observado na Etapa II (550 mg DQO/L de etanol, $550 \mathrm{mg}$ DQO/L de metanol, 14 mg/L de LAS, 0,2 g DQO/g STV.d e 1,2 kg DQO/m³.d). Na etapa IV observou-se diâmetro médio de 3,2 $\pm 0,4 \mathrm{~mm}$ (150 mg DQO/L de etanol, $150 \mathrm{mg}$ DQO/L de metanol, $14 \mathrm{mg} / \mathrm{L}$ de LAS, 0,06 g DQO/g STV.d e 0,3 kg DQO/m³.d).

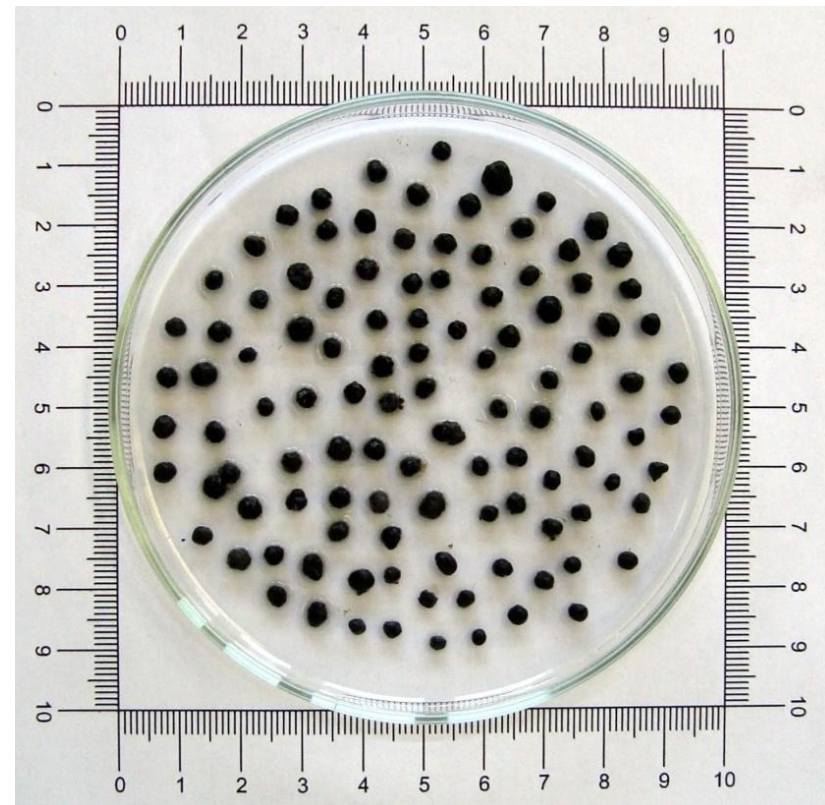

Figura 5.7: Imagem capturada de grânulos da manta de lodo 


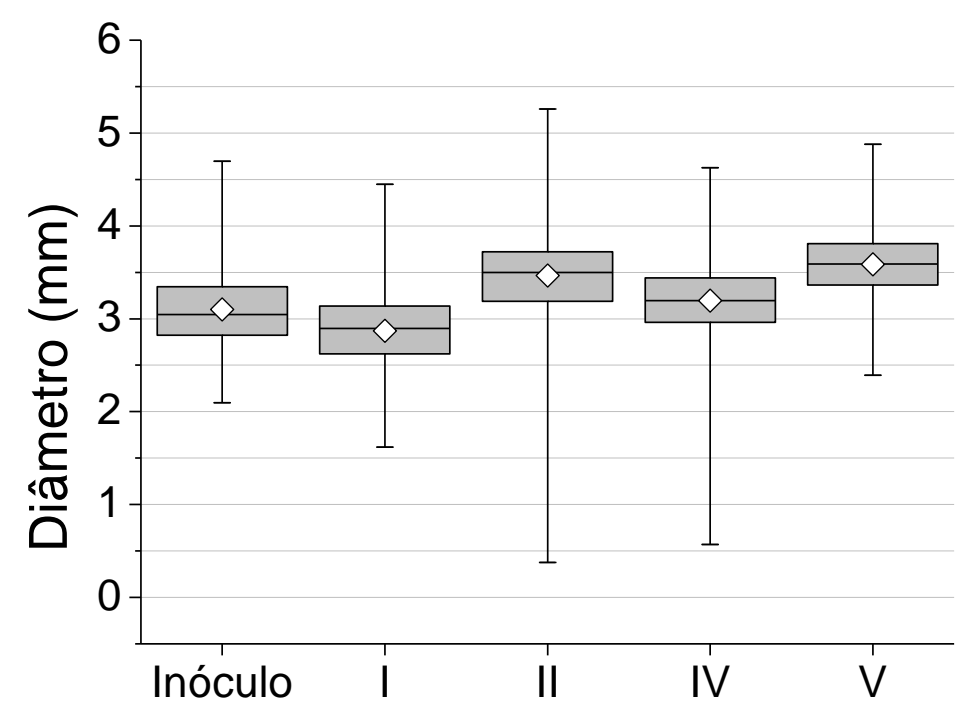

Figura 5.8: Box-plot para distribuição do diâmetro dos grânulos, no inóculo e Etapas I, II, IV e $\mathrm{V}$ do reator $\mathrm{R}_{\mathrm{UASB}}$, em amostra de 300 grânulos.

A nucleação dos grânulos de reatores UASB pode ocorrer em função do crescimento de arquéias metanogênicas semelhantes à Methanosaeta e Methanosarcina. Ambas são consideradas as arquéias responsáveis pela formação do núcleo. A contribuição da primeira devido à boa capacidade de adesão e, a última, em função da capacidade de crescer formando agregados ou pacotes, além de excretar polímero extracelular, no qual poderá aderir-se Methanosaeta. Contudo, a concentração de ácido acético é a forças que direciona a formação do núcleo (WU et al., 1992; SCHMIDT e AHRING, 1996). No caso específico desse trabalho foi observado aumento do tamanho dos grânulos, uma vez que foram usados grânulos bem constituídos provenientes de reator UASB da Avícola Dacar. Provavelmente, a adição de metanol, substrato para Methanosarcina (BOONE e CASTENHOLZ, 2001) tenha favorecido a manutenção de tais células nesse biofilme. Methanosaeta, também fez parte da composição granulada, sendo favorecida devido a presença de ácido acético $(8-21 \mathrm{mg} / \mathrm{L})$ proveniente da degradação do etanol, uma vez que são microrganismos acetoclásticos especializadas na utilização desse ácido (BOONE e CASTENHOLZ, 2001), 


\subsubsection{Exames microscópicos}

Por meio da microscopia de contraste de fase e fluorescência de amostras do reator UASB verificou-se a presença de diversas morfologias e arranjos, como sarcinas fluorescentes semelhantes à Methanosarcina sp., arranjo semelhante à Methanosaeta sp., bacilos retos, bacilos curvos, filamentos, cocos e cocos fluorescentes (Figura 5.9). Observouse arranjo de sarcina fluorescente semelhantes à Methanosarcina sp. desde a Etapa II, em que foi adicionado metanol à água residuária sintética. Com a aeração da água de abastecimento na Etapa IV tornou-se mais difícil encontrar as morfologias de sarcinas fluorescentes e arranjos semelhantes à Methanosaeta sp. A presença de morfologias de semelhantes à arquéias metanogênicas (Methanosarcina e Methanosaeta) indicou a manutenção dos grânulos, uma vez que ambas são importantes para o desenvolvimento da biomassa na forma granulada (SCHMIDT e AHRING, 1996). 


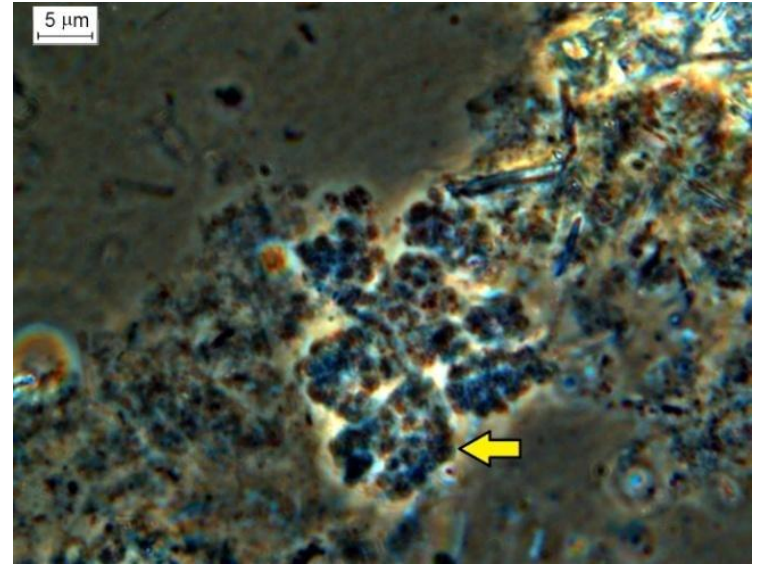

(a)

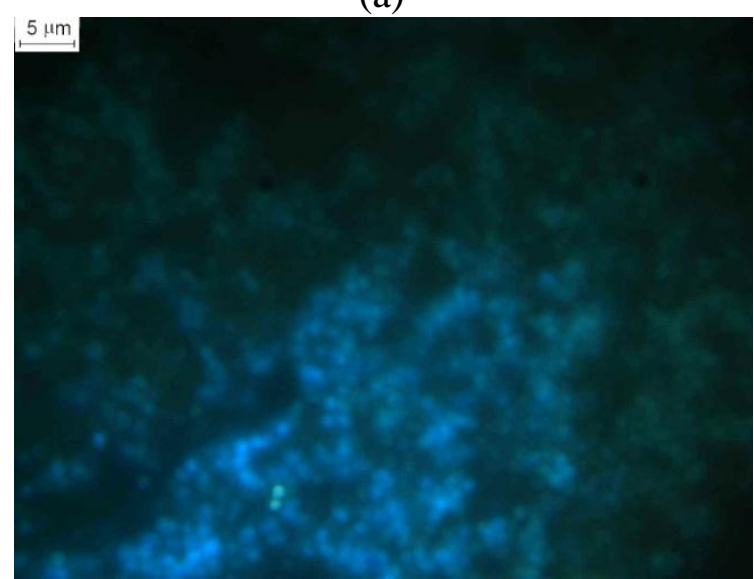

(c)

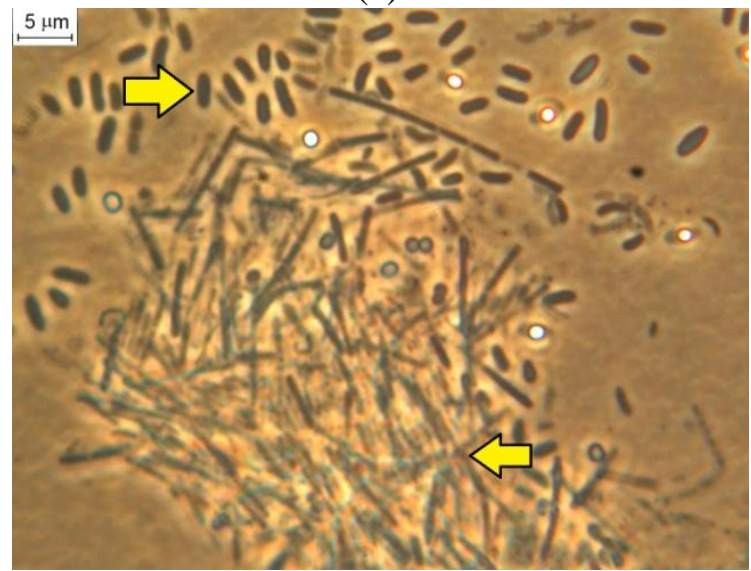

(e)

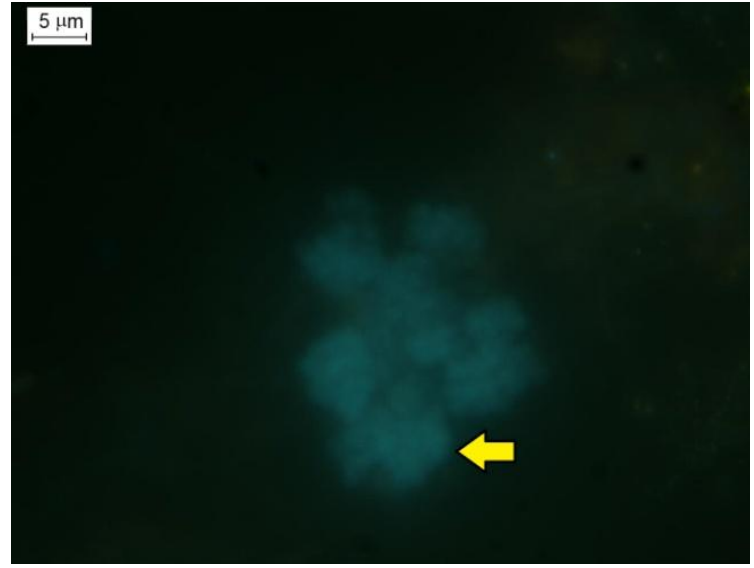

(b)

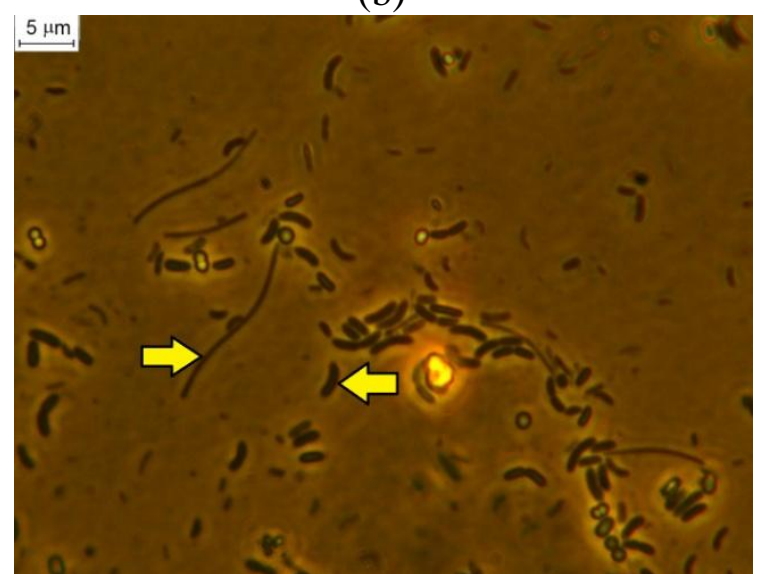

(d)

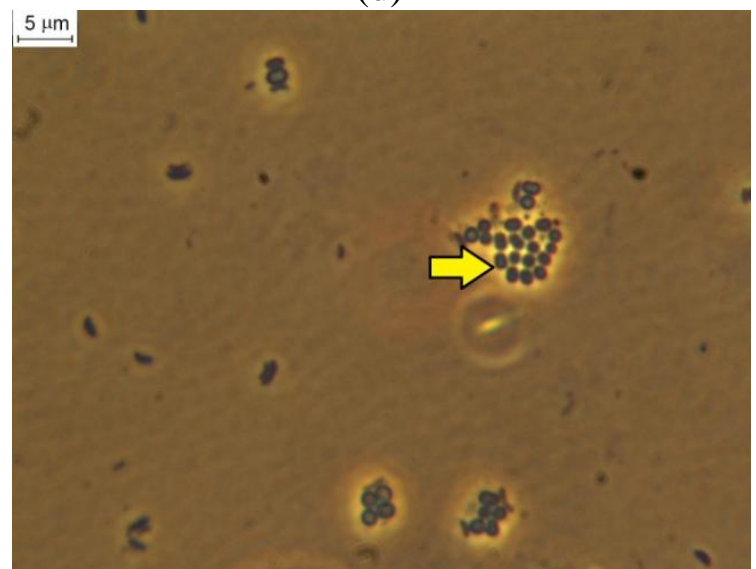

(f)

Figura 5.9: Morfologias observadas em amostras do reator $\mathrm{R}_{\mathrm{UASB}}$ : sarcinas fluorescentes semelhantes à Methanosarcina sp. (contraste de fase - a - e fluorescência - b), cocos fluorescentes (c), bacilos curvos, filamentos (d), bacilos retos, arranjo semelhantes à Methanosaeta sp. (e) e cocos (f) 


\subsubsection{Hibridação fluorescente in situ}

Não foi observada diferença significativa na composição dos domínios Archaea e Bacteria até a Etapa II (Figura 5.10). Até a Etapa II observou-se $64 \pm 3 \%$ de microrganismos do domínio Archaea e $38 \pm 2 \%$ do domínio Bacteria. Essa composição foi similar ao observado no inóculo (Archaea: 62 $\pm 2 \%$; Bacteria: $37 \pm 3 \%$ ). Em virtude da aeração da água de abastecimento na Etapa IV, observou-se decréscimo de microrganismos do domínio Archaea

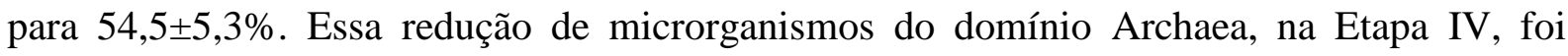
relacionada com o aumento da concentração de ácido acético para 70 mg/L (Figura 5.4, p. 55), uma vez que as arquéias metanogênicas acetoclásticas são as principais consumidoras desse ácido em sistemas anaeróbios. Após a recuperação do sistema anaeróbio e adição de

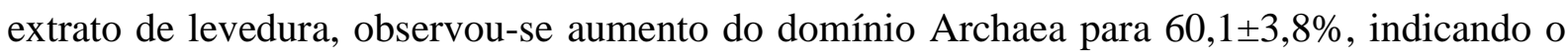
reestabelecimento do equilíbrio nos processos anaeróbios. 


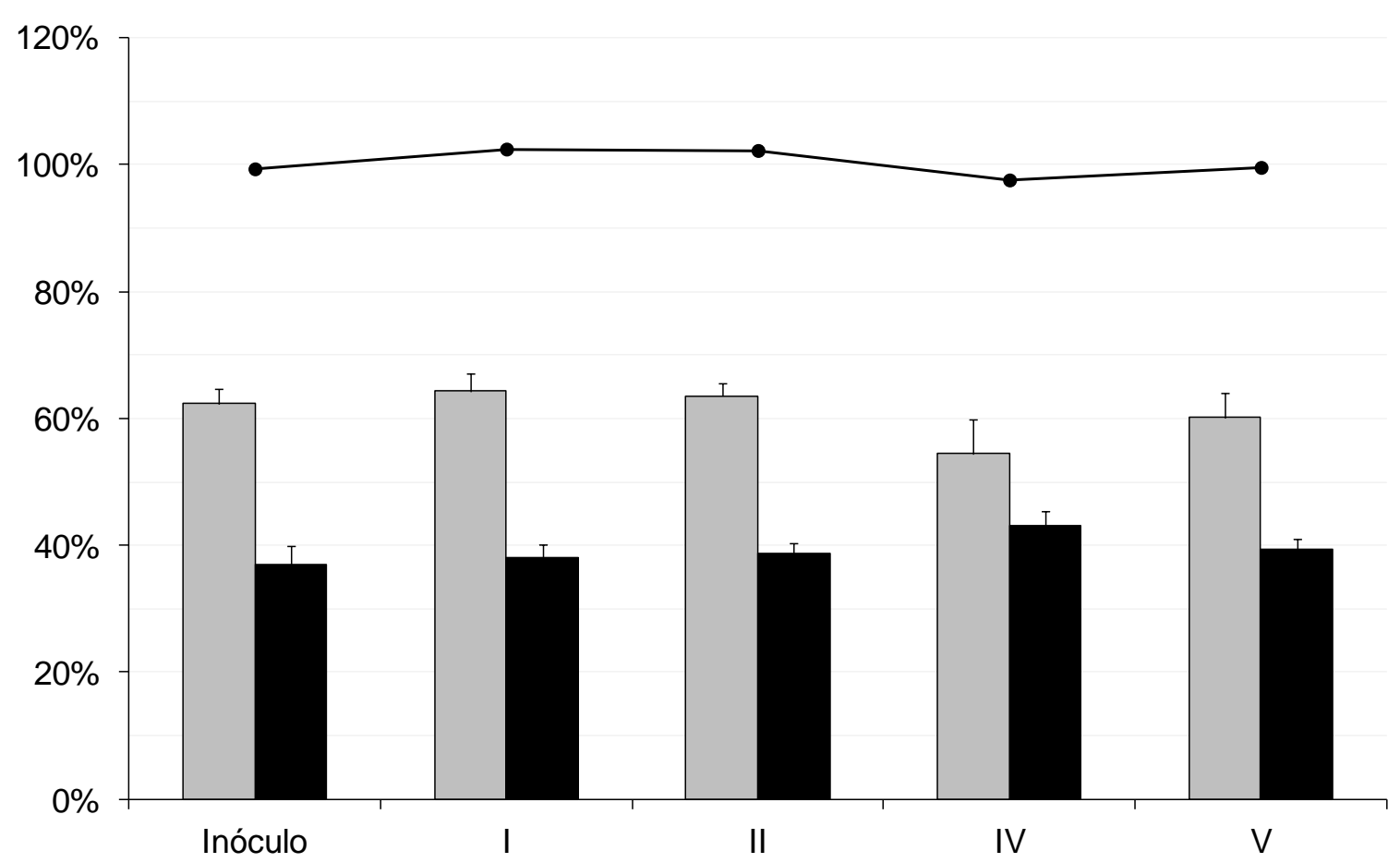

Figura 5.10: Composição da comunidade microbiana do inóculo e de amostras do reator $\mathrm{R}_{\text {UASB }}$ para os domínios Archaea (ARC915) ( $\square$ ) e Bacteria (EUB338) ( $\mathbf{\square}$ ), com respectivo erro padrão e soma das percentagens

Ao contrário do observado mediante FISH (maior parcela do domínio Archaea), observou-se menor parcela de arquéias metanogênicas segundo estimativa de NMP (Etapa II:

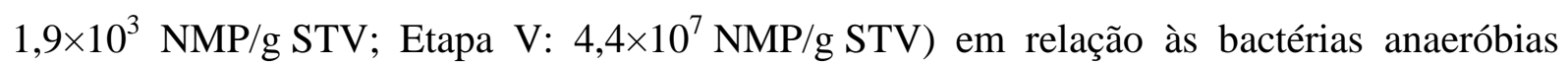
totais (Etapa II: $1,9 \times 10^{8} \mathrm{NMP} / \mathrm{g} \mathrm{STV}$; Etapa V: $3,8 \times 10^{11} \mathrm{NMP} / \mathrm{g} \mathrm{STV}$ ). Em reatores em batelada, Domingues (2001) observou diferenças entre as determinações de populações do domínio Archaea e Bacteria obtidas mediante NMP e FISH, atribuindo essas diferenças às metodologias de cada análise; enquanto, o NMP estima as populações por meio do crescimento celular seletivo, a quantificação por FISH considera as células ativas em determinada condição.

A Figura 5.11 refere-se ao campo microscópico de amostra hibridada com a sonda ARC915 (domínio Archaea) (a), DAPI (b) e contraste de fase (c). A Figura 5.12 refere-se à amostra hibridada com a sonda EUB338 (domínio Bacteria) (a), além de respectivo campo microscópico com DAPI (b) e contraste de fase (c). 


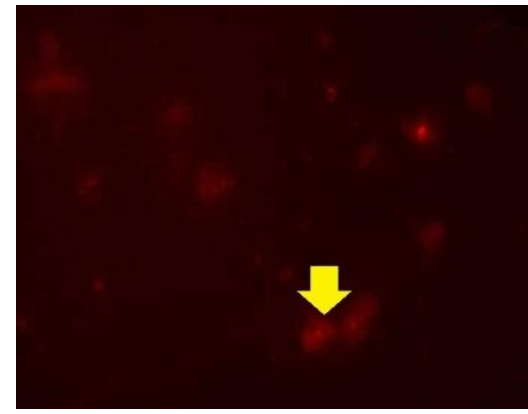

(a)

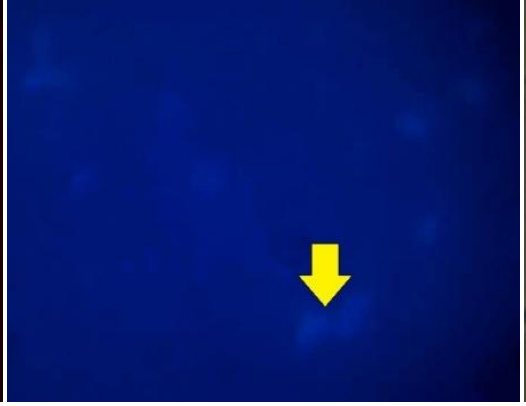

(b)

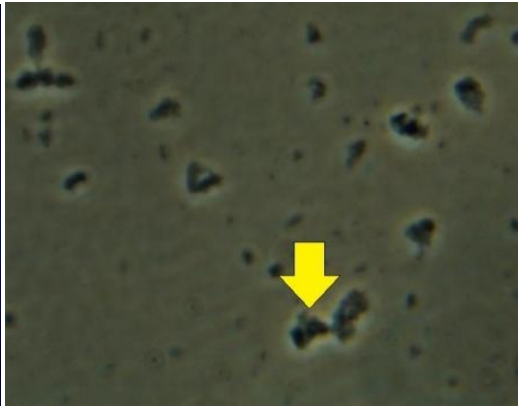

(c)

Figura 5.11: Campos microscópicos de amostra da Etapa II hibridada com a sonda ARC915 (a), coloração com DAPI (b) e contraste de fase (c)

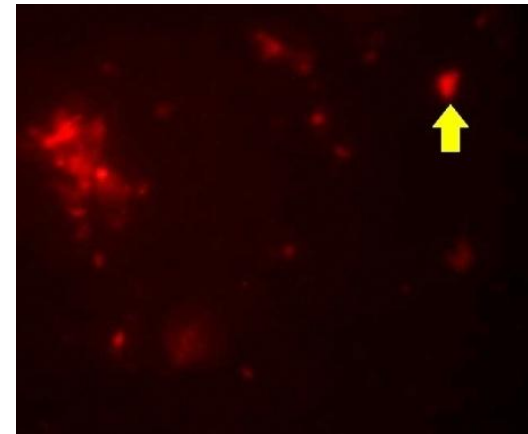

(a)

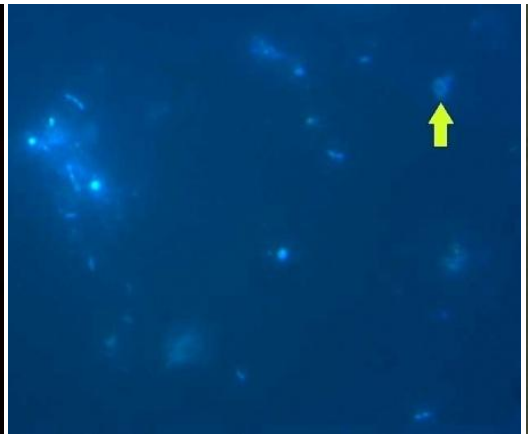

(b)

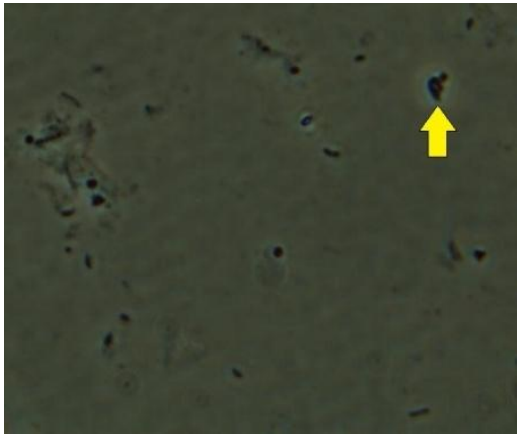

(c)

Figura 5.12: Campos microscópicos de amostra da Etapa II hibridada com a sonda EUB338 (a), coloração com DAPI (b) e contraste de fase (c)

\subsubsection{Considerações}

Usando apenas alcoóis de cadeia curta (metanol e etanol) como co-substratos, a remoção de LAS variou entre 29 e $41 \%$ (Etapas II e III). Atribuiu-se a menor eficiência (29\%) à ausência de recirculação de efluente, que contribuiu para a maior diferença (cerca de 20\%) em relação à etapa de adição de extrato de levedura (Etapa V; 50\%). Verificou-se menor diferença da remoção de LAS entre as Etapas III e V (com recirculação de efluente), em cerca de $10 \%$. Todavia, no período em que foi adicionado apenas alcoóis de cadeia curta (metanol e etanol) observou-se perda significativa de biomassa (12 mg STV/L.d). 
A adição de co-substrato complexo (extrato de levedura, Etapa V) resultou em maior remoção de LAS (50\%). Observou-se menor perda de biomassa do reator (9 mg STV/L.d) com a adição de extrato de levedura, além do aumento da estimativa de populações de arquéias metanogênicas e bactérias anaeróbias totais (quatro e três unidades log, respectivamente).

Por meio da análise de FISH, não foram observadas alterações significativas da composição da comunidade microbiana referente aos domínios Archaea (cerca de 60\%) e Bacteria (cerca de 40\%), após a adição de LAS. Alteração significativa foi observada apenas após a aeração da água de abastecimento, com a redução dos microrganismos do domínio Archaea para 55\%.

A aeração da água de abastecimento provocou aumento da concentração de ácido acético para $70 \mathrm{mg} / \mathrm{L}$, reduzindo a remoção de DQO e LAS. Apesar da redução das eficiências de remoção de DQO e LAS, observou-se a possibilidade de recuperação do sistema anaeróbio, tanto de remoção de carga orgânica, como de LAS. 


\subsection{Avaliação da influência da biodisponibilidade de LAS, TDH e concentração de co- substratos}

Observou-se pouca variação do pH efluente nos reatores; ou seja, de 7,1 a 7,6. (Tabela 5.4 e Tabela 5.5). Em relação à alcalinidade efluente também foi observada pouca variação, sendo verificado valores de alcalinidade total entre 140 e $318 \mathrm{mg} \mathrm{CaCO}_{3} / \mathrm{L}$, com exceção do reator $\mathrm{R}_{35 \mathrm{~A}}$, cuja alcalinidade total foi acima de $800 \mathrm{mg} \mathrm{CaCO} / \mathrm{L}$. A alcalinidade total observada nesse reator $\left(\mathrm{R}_{35 \mathrm{~A}}\right)$ foi maior que nos demais devido à quantidade de bicarbonato de sódio adicionada ao afluente $(800 \mathrm{mg} / \mathrm{L})$ para manter o $\mathrm{pH}$ em torno de 7,0. Nos reatores $\mathrm{R}_{35 \mathrm{D}}$ e $\mathrm{R}_{\mathrm{BCS}}$ (baixa concentração de co-substratos) constatou-se elevado consumo de alcalinidade, com 600-700 mg/L de bicarbonato de sódio afluente, resultando em alcalinidade total efluente de 140-190 $\mathrm{mg} \mathrm{CaCO}_{3} / \mathrm{L}$. 
Tabela 5.4: Parâmetros analisados nos reatores variando a biodisponibilidade de LAS

\begin{tabular}{lcccc}
\hline Parâmetro & $\mathrm{R}_{35 \mathrm{~A}}$ & $\mathrm{R}_{35 \mathrm{~B}}$ & $\mathrm{R}_{35 \mathrm{C}}$ & $\mathrm{R}_{35 \mathrm{D}}$ \\
\hline Ácidos orgânicos voláteis (mg HAc/L) & & & & \\
$\quad$ Efluente & $39 \pm 24$ & $42 \pm 31$ & $25 \pm 24$ & $37 \pm 20$ \\
Alcalinidade (mg CaCO $3 / \mathrm{L})$ & & & & \\
$\quad$ Efluente & & & & \\
$\quad$ Parcial & $637 \pm 139$ & $150 \pm 37$ & $163 \pm 32$ & $142 \pm 37$ \\
$\quad$ Total & $829 \pm 167$ & $196 \pm 49$ & $209 \pm 38$ & $186 \pm 28$ \\
Biomassa no reator (g/L) & & & & \\
ST & $16 \pm 3$ & $5,9 \pm 0,9$ & $2,3 \pm 0,7$ & $1,3 \pm 0,5$ \\
STV & $13 \pm 2$ & $4,5 \pm 0,7$ & $1,5 \pm 0,5$ & $0,7 \pm 0,3$ \\
STF & $2,5 \pm 0,6$ & $1,4 \pm 0,5$ & $0,8 \pm 0,4$ & $0,6 \pm 0,2$ \\
DQO & & & & \\
$\quad$ Afluente (mg/L) & $3458 \pm 730$ & $474 \pm 93$ & $231 \pm 44$ & $106 \pm 18$ \\
Efluente (mg/L) & $134 \pm 25$ & $60 \pm 21$ & $56 \pm 20$ & $29 \pm 14$ \\
Remoção (\%) & $96 \pm 1$ & $87 \pm 6$ & $76 \pm 9$ & $73 \pm 12$ \\
Carga orgânica específica (COE) & $0,18 \pm 0,06$ & $0,07 \pm 0,02$ & $0,10 \pm 0,02$ & $0,10 \pm 0,02$ \\
$\quad$ g DQO/g STV.d) & & & & \\
LAS & $12 \pm 2$ & $13 \pm 3$ & $13 \pm 2$ & $12 \pm 2$ \\
$\quad$ Afluente (mg/L) & $3 \pm 2$ & $4 \pm 2$ & $4 \pm 2$ & $6 \pm 1$ \\
Efluente (mg/L) & & & & \\
pH & & & & \\
$\quad$ Efluente & $7,6 \pm 0,2$ & $7,2 \pm 0,1$ & $7,3 \pm 0,2$ & $7,1 \pm 0,1$ \\
SST & & & & \\
$\quad$ Efluente (mg/L) & $64 \pm 35$ & $47 \pm 42$ & $34 \pm 27$ & $13 \pm 10$ \\
$\quad$ Total descartado no efluente (mg) & 2.557 & 1.851 & 1.335 & 531 \\
TDH (h) & $34 \pm 3$ & $34 \pm 5$ & $36 \pm 5$ & $35 \pm 4$ \\
\hline
\end{tabular}


Tabela 5.5: Parâmetros analisados nos reatores variando TDH e concentração de co-substratos

\begin{tabular}{|c|c|c|c|}
\hline Parâmetro & $\mathrm{R}_{\mathrm{BCS}}$ & $\mathrm{R}_{6}$ & $\mathrm{R}_{80}$ \\
\hline \multicolumn{4}{|l|}{ Ácidos orgânicos voláteis (mg HAc/L) } \\
\hline Efluente & $33 \pm 14$ & $49 \pm 23$ & $18 \pm 10$ \\
\hline \multicolumn{4}{|l|}{ Alcalinidade $\left(\mathrm{mg} \mathrm{CaCO}_{3} / \mathrm{L}\right)$} \\
\hline \multicolumn{4}{|l|}{ Efluente } \\
\hline Parcial & $110 \pm 52$ & $246 \pm 19$ & $110 \pm 46$ \\
\hline Total & $144 \pm 64$ & $318 \pm 21$ & $140 \pm 61$ \\
\hline \multicolumn{4}{|l|}{ Biomassa no reator $(\mathrm{g} / \mathrm{L})$} \\
\hline ST & $1,6 \pm 0,5$ & $6 \pm 1$ & $1,7 \pm 0,5$ \\
\hline STV & $1,3 \pm 0,4$ & $5 \pm 1$ & $1,1 \pm 0,4$ \\
\hline STF & $0,3 \pm 0,1$ & $0,6 \pm 0,2$ & $0,6 \pm 0,2$ \\
\hline \multicolumn{4}{|l|}{ DQO } \\
\hline Afluente (mg/L) & $57 \pm 22$ & $222 \pm 23$ & $171 \pm 31$ \\
\hline Efluente $(\mathrm{mg} / \mathrm{L})$ & $21 \pm 13$ & $44 \pm 19$ & $49 \pm 41$ \\
\hline Remoção (\%) & $63 \pm 19$ & $80 \pm 8$ & $71 \pm 23$ \\
\hline $\begin{array}{l}\text { Carga orgânica específica (COE) } \\
\text { (g DQO/g STV.d) }\end{array}$ & $0,03 \pm 0,02$ & $0,18 \pm 0,04$ & $0,05 \pm 0,03$ \\
\hline \multicolumn{4}{|l|}{ LAS } \\
\hline Afluente (mg/L) & $12 \pm 2$ & $12 \pm 2$ & $12 \pm 2$ \\
\hline Efluente (mg/L) & $2 \pm 1$ & $9 \pm 2$ & $2 \pm 1$ \\
\hline \multicolumn{4}{|l|}{$\mathrm{pH}$} \\
\hline Efluente & $7,1 \pm 0,1$ & $7,3 \pm 0,2$ & $7,0 \pm 0,4$ \\
\hline \multicolumn{4}{|l|}{ SST } \\
\hline Efluente (mg/L) & $6 \pm 6$ & $12 \pm 4$ & $13 \pm 11$ \\
\hline Total descartado no efluente (mg) & 267 & 2.787 & 235 \\
\hline TDH (h) & $35 \pm 5$ & $5,7 \pm 0,3$ & $80 \pm 20$ \\
\hline
\end{tabular}

A remoção de DQO variou de 63\% a 96\% (Tabela 5.4 e Tabela 5.5), em virtude das diferentes concentrações de DQO afluente em cada reator. Obteve-se a maior remoção de DQO (96\%) para o reator $\mathrm{R}_{35 \mathrm{~A}}$ devido a maior concentração afluente $(3458 \mathrm{mg} / \mathrm{L})$. A menor remoção $(63 \%)$ de DQO foi observada no reator $\mathrm{R}_{\mathrm{BCS}}$, em virtude da menor concentração de DQO afluente (57 mg/L). Apesar dessa variação na remoção de DQO, observou-se concentração de DQO efluente abaixo de $60 \mathrm{mg} / \mathrm{L}$, com exceção do reator $\mathrm{R}_{35 \mathrm{~A}}(134 \mathrm{mg} / \mathrm{L})$.

Com relação aos ácidos orgânicos voláteis, verificou-se a presença de ácido butírico, valérico, isovalérico e capróico, presente em todos os reatores, em concentração média de 0,5 a 9,5 mg/L (Figura 5.13). Em virtude da baixa concentração de co-substratos $\left(R_{B C S}\right.$ e $\left.R_{80}\right)$ e do alto TDH $\left(\mathrm{R}_{80}: 80 \mathrm{~h}\right)$ foram detectados menos ácidos orgânicos voláteis nos reatores $\mathrm{R}_{\mathrm{BCS}}(7$ ácidos orgânicos voláteis) e $\mathrm{R}_{80}$ (4 ácidos orgânicos voláteis). 

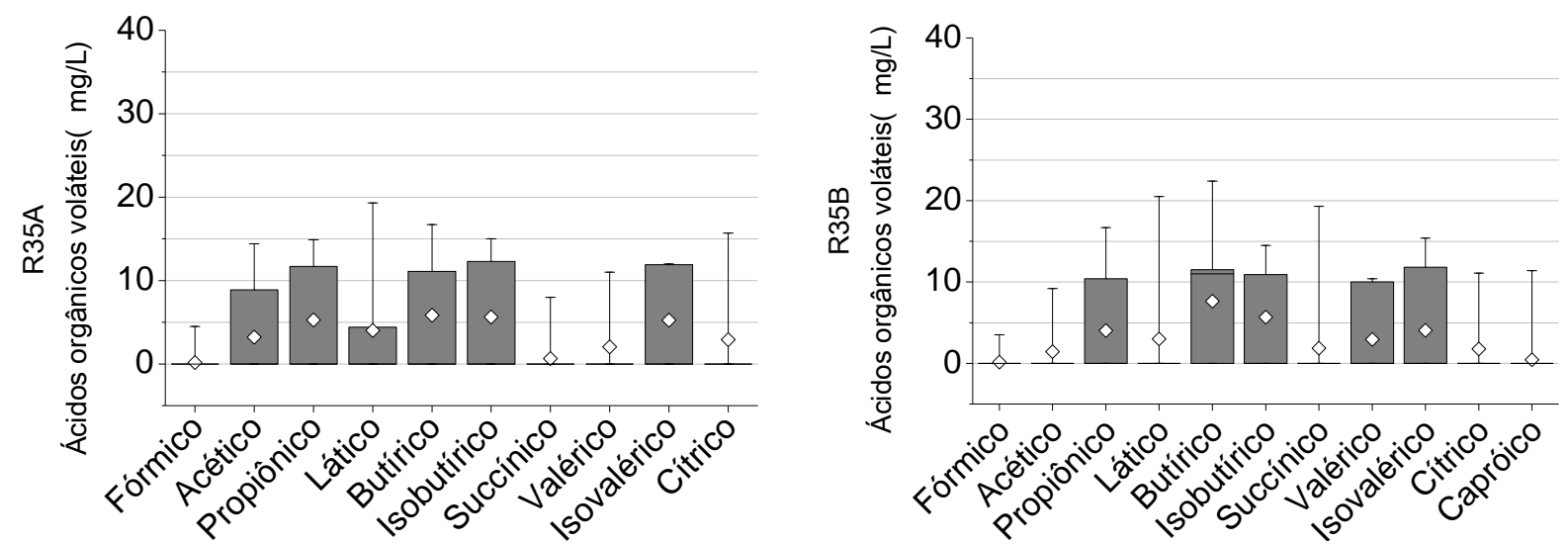

(a)
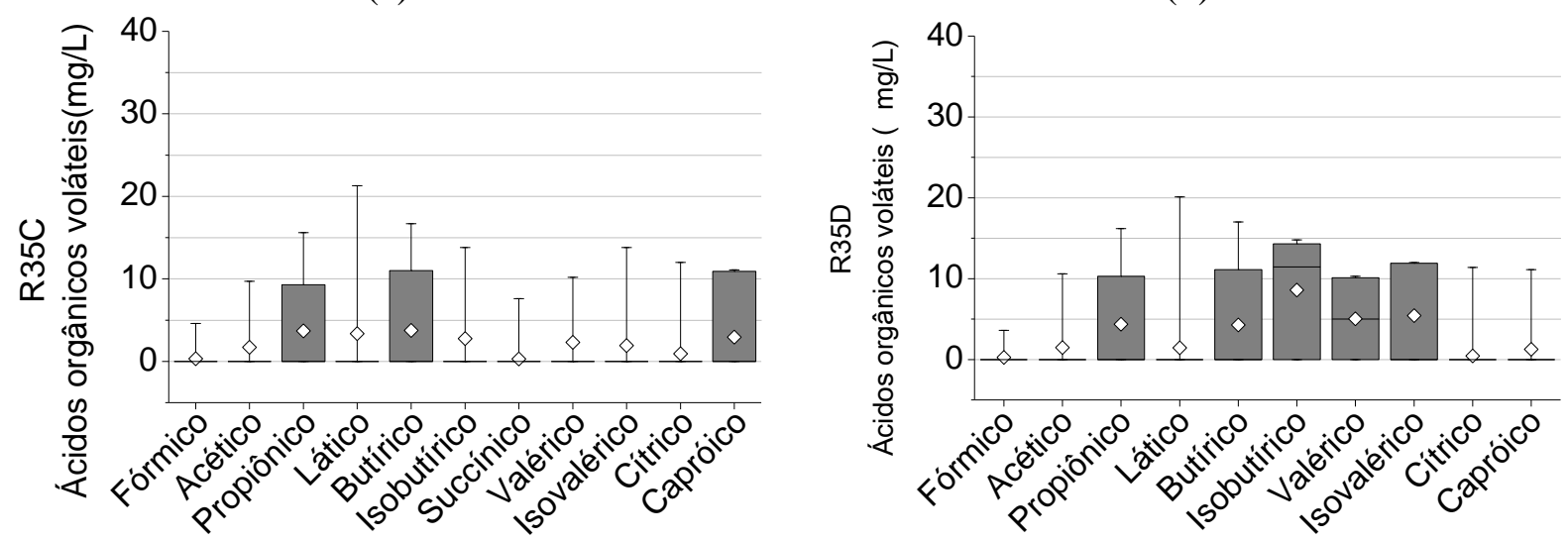

(c)

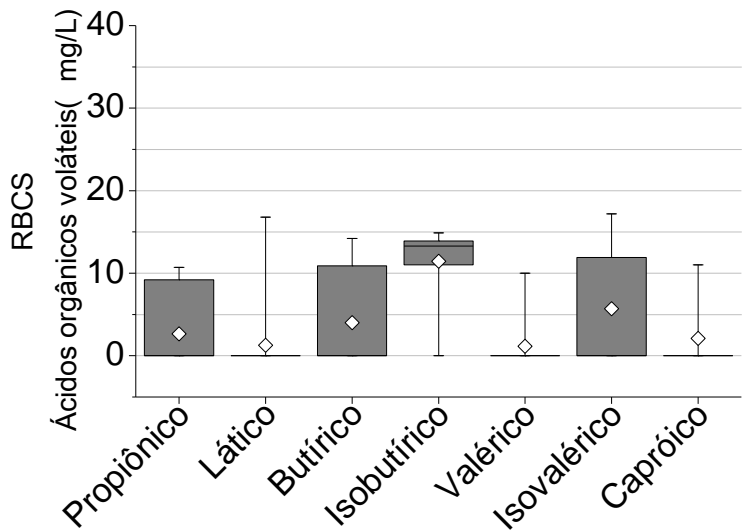

(e)

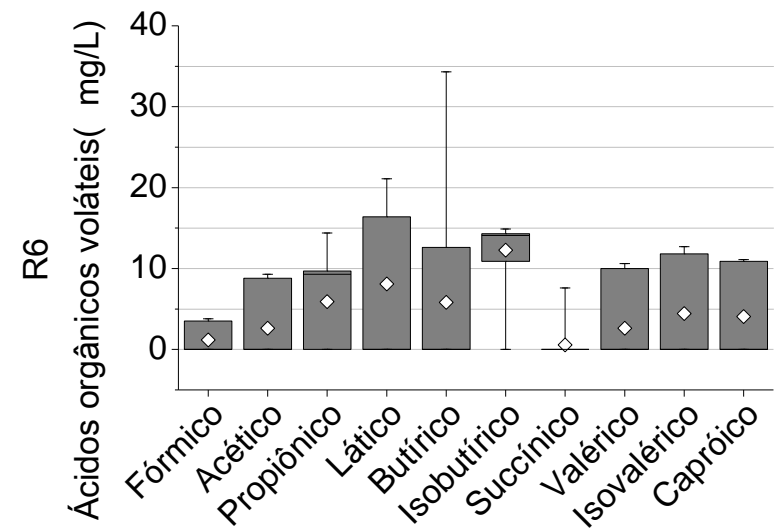

(f)

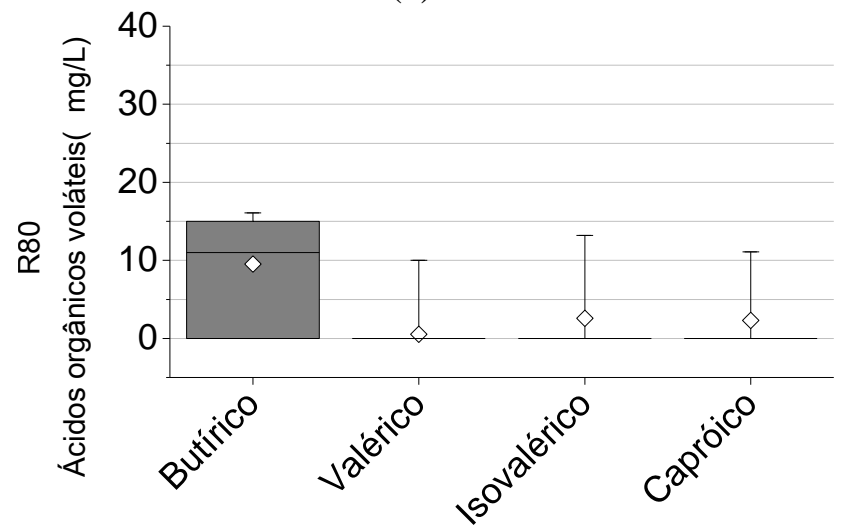

(g)

Figura 5.13: Box-plot de ácidos orgânicos voláteis detectados em 25 amostras de efluente dos reatores $R_{35 \mathrm{~A}}$ (a), $R_{35 \mathrm{~B}}(\mathrm{~b}), \mathrm{R}_{35 \mathrm{C}}(\mathrm{c}), \mathrm{R}_{35 \mathrm{D}}(\mathrm{d}), \mathrm{R}_{\mathrm{BCS}}(\mathrm{e}), \mathrm{R}_{6}$ (f) e $R_{80}(\mathrm{~g})$ 
Estudos anteriores (JIANG et al., 2007; ZHANG et al., 2009) atribuíram a persistência de ácidos isobutírico e isovalérico na presença de LAS à taxa de decomposição de ácidos ramificados, que é menor que seus respectivos isômeros de cadeia curta e reta (WANG et al., 1999). No presente estudo, detectou-se 1,9-5,7 mg/L de ácido isovalérico em todos os reatores e 2,8-12,3 mg/L de ácido isobutírico em quase todos, com exceção do reator $\mathbf{R}_{80}$.

A concentração de SST efluente variou de 6 a $64 \mathrm{mg} / \mathrm{L}$ (Tabela 5.4 e Tabela 5.5). A maior liberação de biomassa (>30 mg SST/L) foi observada nos reatores com maior concentração de biomassa (sólidos no reator entre 2,3 e 16 g ST/L). Em virtude da maior

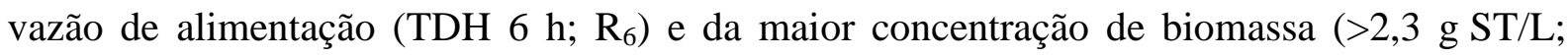
$R_{35 \mathrm{~A}}, R_{35 \mathrm{~B}}$ e $R_{35 \mathrm{C}}$ ) observou-se maior quantidade de sólidos descartados no efluente (entre 1.335 e $2.787 \mathrm{mg}$ ) nos reatores $R_{35 \mathrm{~A}}, \mathrm{R}_{35 \mathrm{~B}}, \mathrm{R}_{35 \mathrm{C}}$ e $\mathrm{R}_{6}$. Todavia, ao final do ensaio constatou-se a integridade do lodo na forma granulada (Figura 5.14).

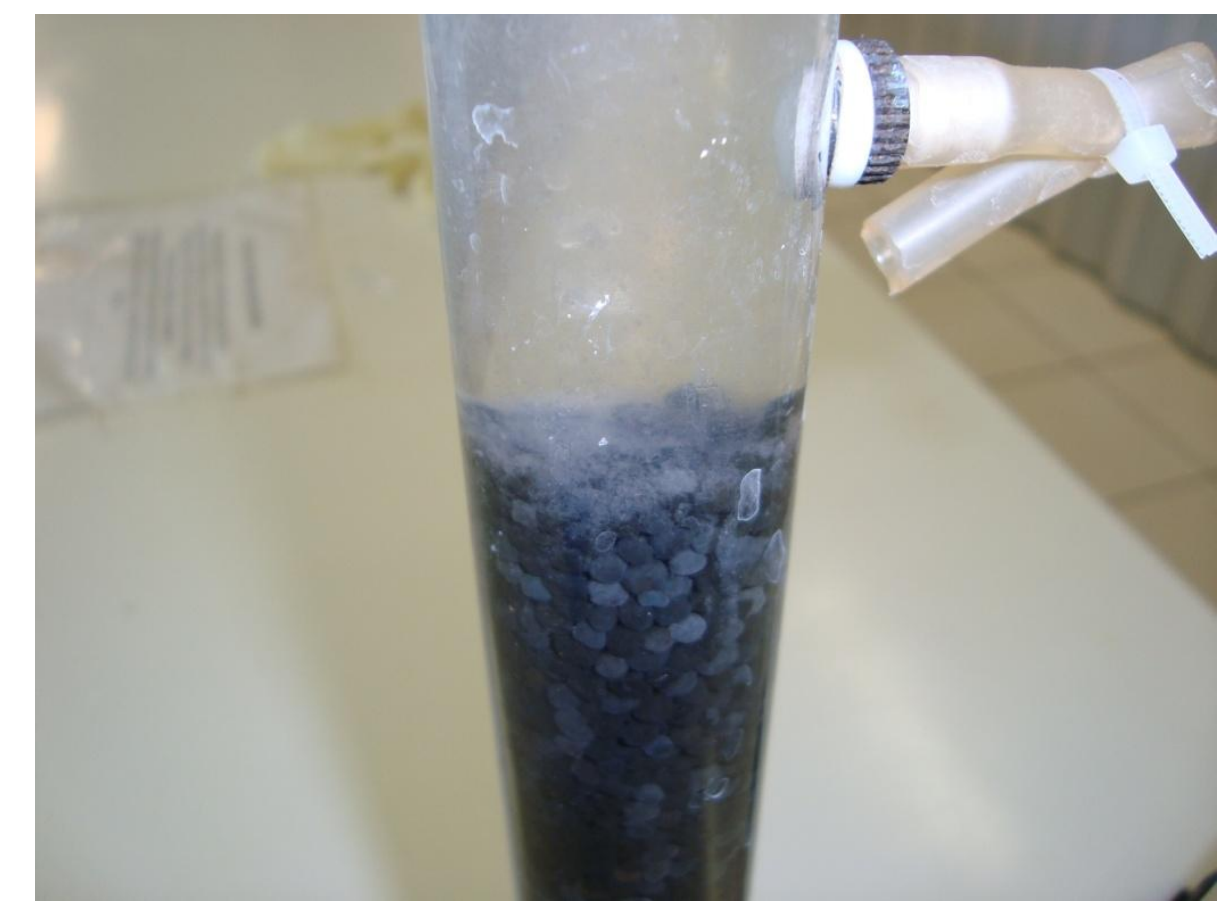

Figura 5.14: Grânulos da manta de lodo do reator $\mathrm{R}_{6}$ ao final da operação 
No separador de fases constatou-se desenvolvimento de biomassa, após cerca de 90 dias de operação (Figura 5.15). Os sólidos voláteis no separador de fases representaram de $11 \%$ a $68 \%$ da biomassa total dos reatores (Figura 5.16), com exceção do reator $\mathrm{R}_{35 \mathrm{~A}}$. No reator $\mathrm{R}_{35 \mathrm{~A}}$ a parcela de sólidos voláteis foi pequena (2\%), devido à maior quantidade de biomassa na manta $\left(8,4 \mathrm{~g}\right.$ STV). No reator $\mathrm{R}_{\mathrm{BCS}}$, a parcela de sólidos voláteis do separador de fases correspondeu a maior parte da biomassa do reator $(68 \%)$.

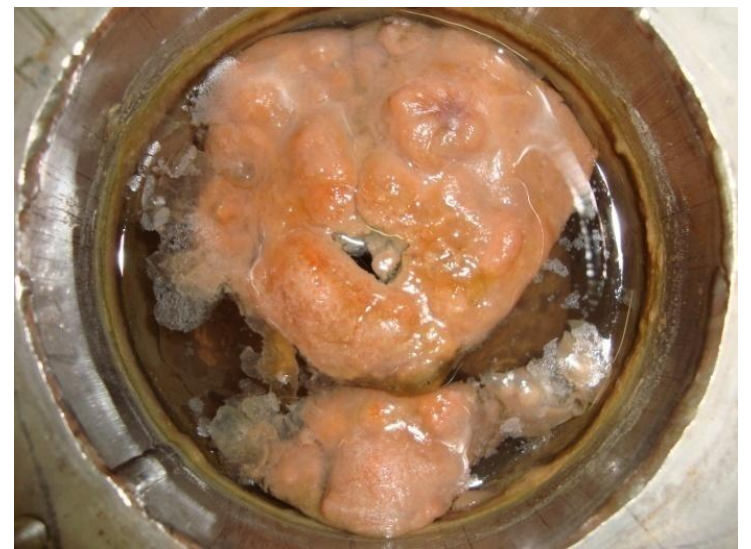

(a)

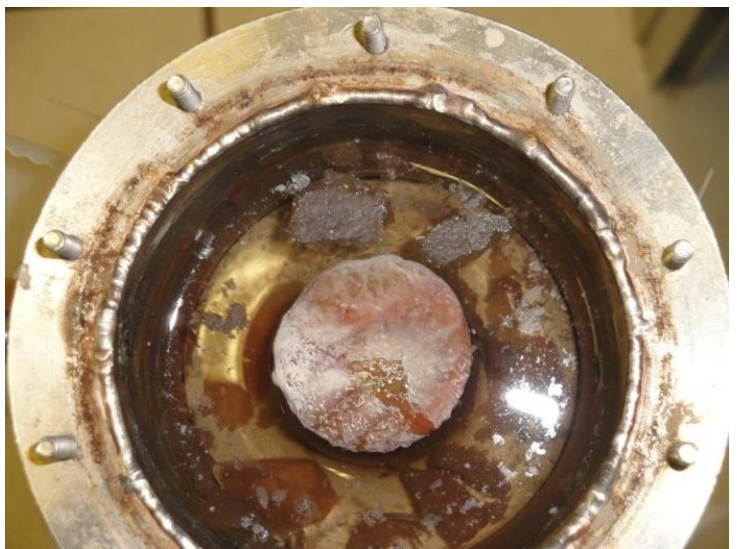

(b)

Figura 5.15: Biomassa ao final do ensaio no separador de fases dos reatores $R_{6}$ (a) e $R_{B C S}(b)$, cuja aparência foi similar ao observado em outros reatores (a aparente diferença entre a biomassa dos reatores $\mathrm{R}_{6}$ e $\mathrm{R}_{\mathrm{BCS}}$ deve-se às condiçãos de luz na captura das imagens)

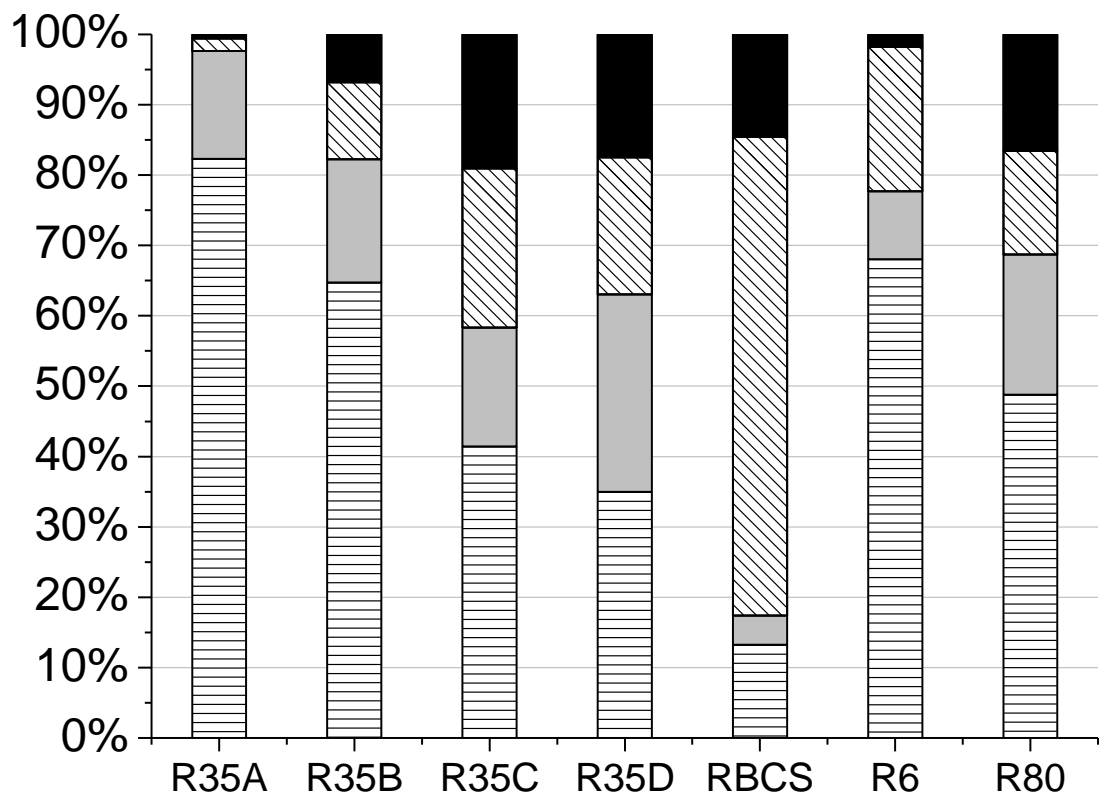

Figura 5.16: Distribuição de sólidos ao final do ensaio: STV (目) e STF ( $\square$ ) na manta de lodo, e STV $(\mathbb{Q})$ e STF $(\square)$ no separador de fases 
Verificou-se condição anaeróbia estrita na manta de lodo, indicada pela transparência do meio após adição de resazurina, no $33^{\circ}$ dia de operação (Figura 5.17a). No separador de fases, a coloração rosa observada dentro do separador de fases (Figura 5.17b) e na saída do efluente (Figura 5.17a) indicaram a condição anaeróbia facultativa.

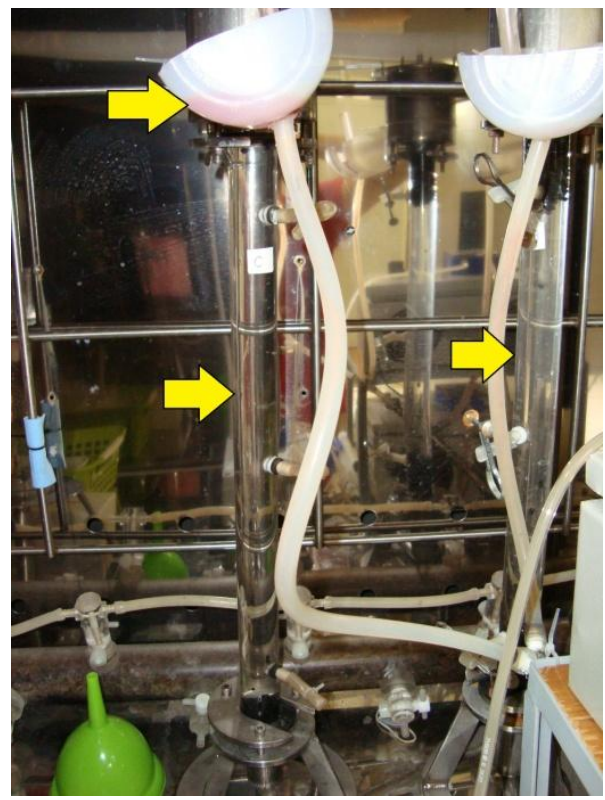

(a)

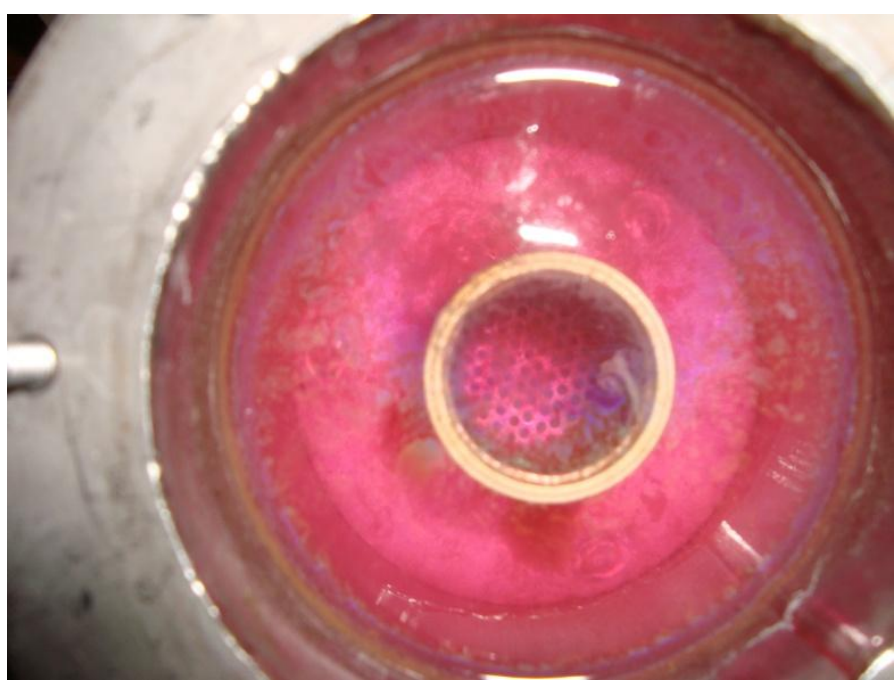

(b)

Figura 5.17: Reatores $R_{35 B}$ e $R_{35 C}(a)$, e separador de fases do reator $R_{35 C}$ (b) após adição de resazurina na alimentação

Nos reatores variando a biodisponibilidade de LAS, pela concentração de biomassa $\left(R_{35 \mathrm{~A}}, \mathrm{R}_{35 \mathrm{~B}}, \mathrm{R}_{35 \mathrm{C}}\right.$ e $\mathrm{R}_{35 \mathrm{D}}$ ), obteve-se degradação de surfactante entre 37 e $53 \%$, de acordo com balanço de massa (Tabela 5.6 e Figura 5.18). Variando o TDH, obteve-se a menor degradação de LAS em TDH 6 h ( $\left.\mathrm{R}_{6}: 18 \%\right)$, e, em 80 h $\left(\mathrm{R}_{80}\right)$, a eficiência foi de 55\%. A maior eficiência degradação de LAS foi observada no reator com concentração de co-substratos baixa $\left(\mathrm{R}_{\mathrm{BCS}}\right.$ : 76\%). A discussão da influência da biodisponibilidade de LAS, TDH e concentração de cosubstratos foi dividida em seções, apresentadas a seguir. 
Tabela 5.6: Balanço de massa de LAS

\begin{tabular}{lccccccc}
\hline Balanço de massa & $\mathrm{R}_{35 \mathrm{~A}}$ & $\mathrm{R}_{35 \mathrm{~B}}$ & $\mathrm{R}_{35 \mathrm{C}}$ & $\mathrm{R}_{35 \mathrm{D}}$ & $\mathrm{R}_{\mathrm{BCS}}$ & $\mathrm{R}_{6}$ & $\mathrm{R}_{80}$ \\
\hline Adicionado (mg) & 497 & 526 & 517 & 487 & 502 & 3027 & 237 \\
Adsorvido biomassa - inicial (mg) & 4 & 2 & 0,6 & 0,4 & 0,4 & 1,6 & 0,5 \\
Efluente (mg) & 141 & 167 & 175 & 229 & 81 & 2370 & 52 \\
Adsorvido biomassa - final (mg) & 170 & 153 & 69 & 27 & 38 & 102 & 54 \\
$\quad \begin{array}{l}\text { Degradado (mg) } \\
\text { Degradado (\%) }\end{array}$ & 186 & 206 & 273 & 231 & 383 & 555 & 131 \\
$\quad$ Carga específica de LAS & $37 \pm 13$ & $39 \pm 11$ & $53 \pm 16$ & $47 \pm 20$ & $76 \pm 8$ & $18 \pm 21$ & $55 \pm 10$ \\
$\quad$ (mg LAS/g STV.d) & 0,6 & 2,0 & 6,1 & 12,3 & 6,5 & 10,1 & 3,9 \\
$\quad \begin{array}{l}\text { Degradação específica de LAS } \\
\quad \text { mg LAS/g STV.d) }\end{array}$ & 0,2 & 0,8 & 3,2 & 5,8 & 4,9 & 1,8 & 2,1 \\
$\quad \begin{array}{l}\text { Taxa de LAS aplicada (mg/L.d) } \\
\text { Duração (d) }\end{array}$ & 8,5 & 9,1 & 8,9 & 8,4 & 8,4 & 51,0 & 4,2 \\
& 90 & 89 & 89 & 89 & 92 & 92 & 87 \\
\hline
\end{tabular}

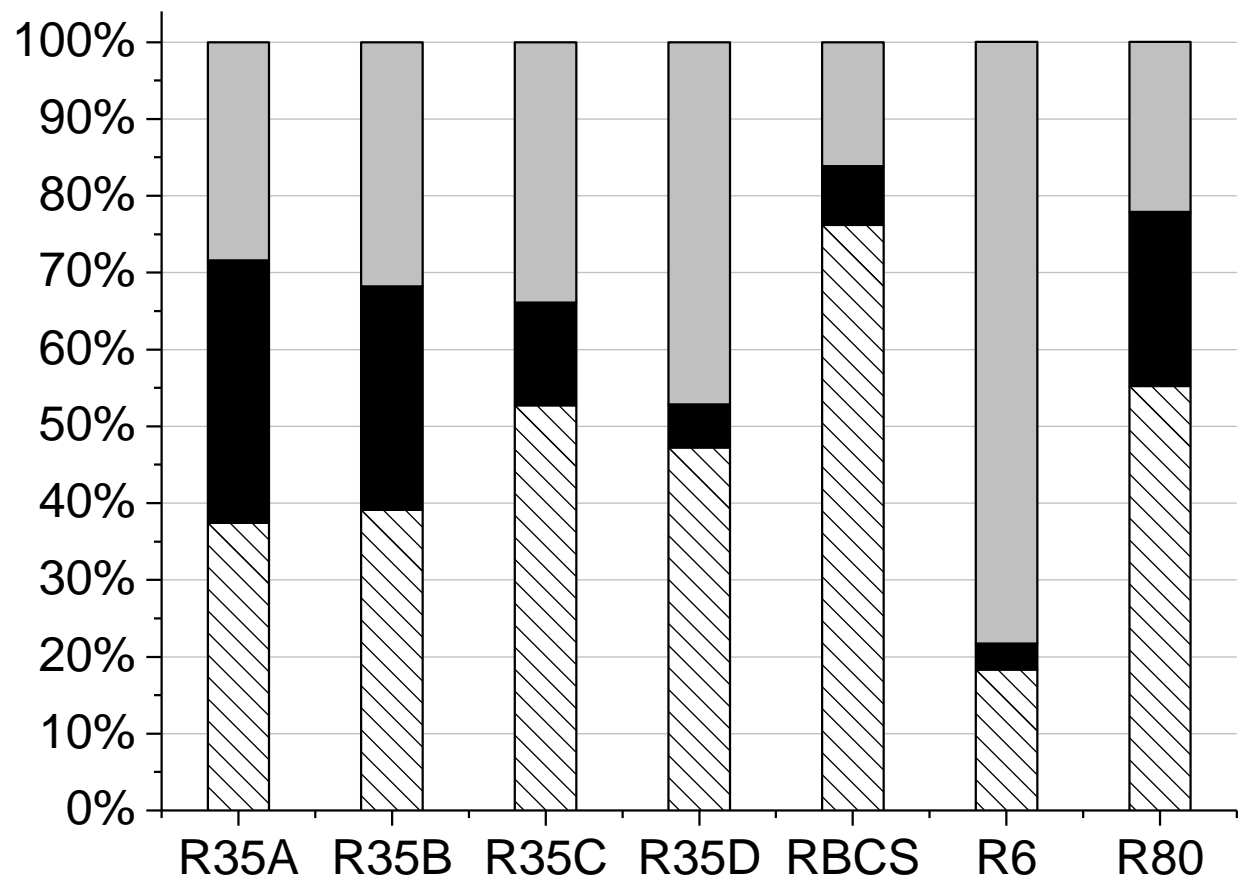

Figura 5.18: Distribuição do destino final de LAS: efluente ( $\square$ ), adsorvido na biomassa ( $\square$ e e degradado $(\mathbb{Q})$

\subsubsection{Influência da biodisponibilidade de LAS}

Observou-se aumento do tempo necessário para o equilíbrio entre a adsorção e degradação de LAS, de 10 dias para 60 dias (reatores $R_{35 A}, R_{35 B}, R_{35 C}$ e $R_{35 D}$ : Figura 5.19), com o aumento da concentração da biomassa nos reatores (de 1,3 g ST/L para 16 g ST/L). 


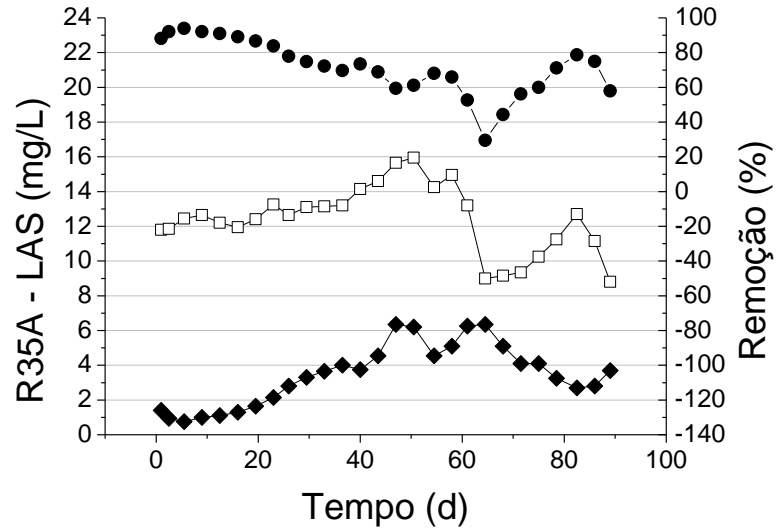

(a)

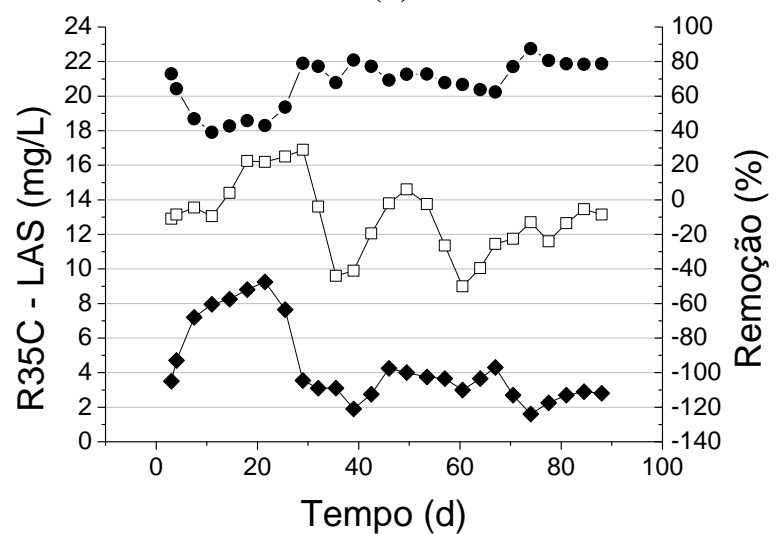

(c)

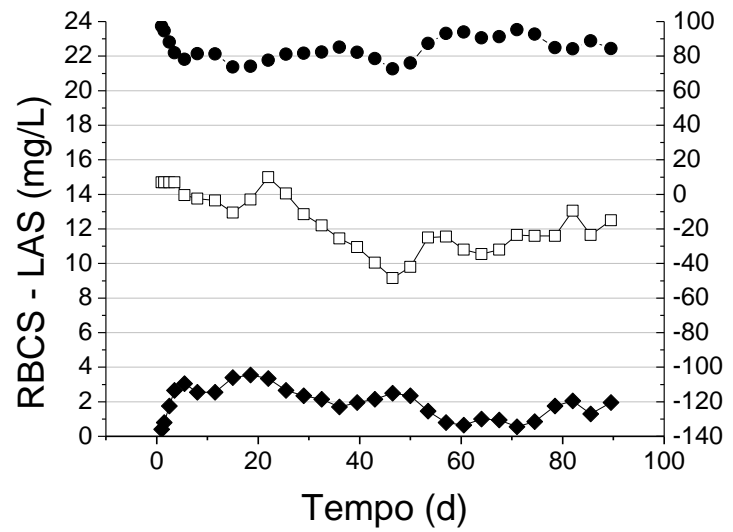

(e)

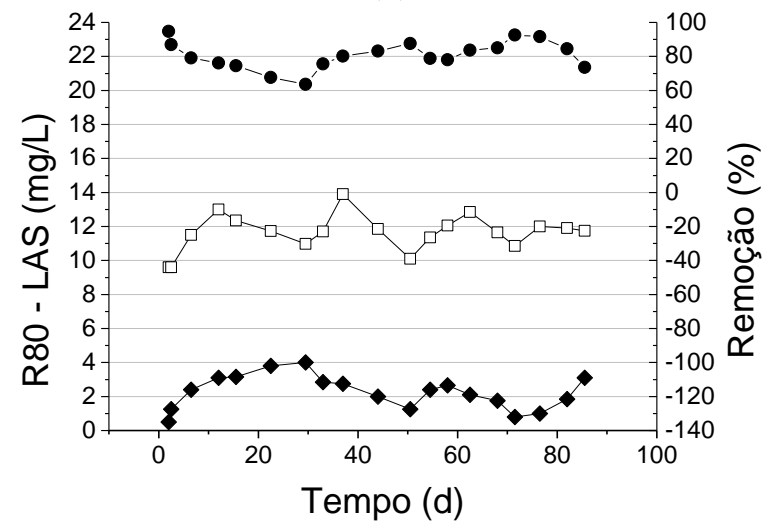

(g)

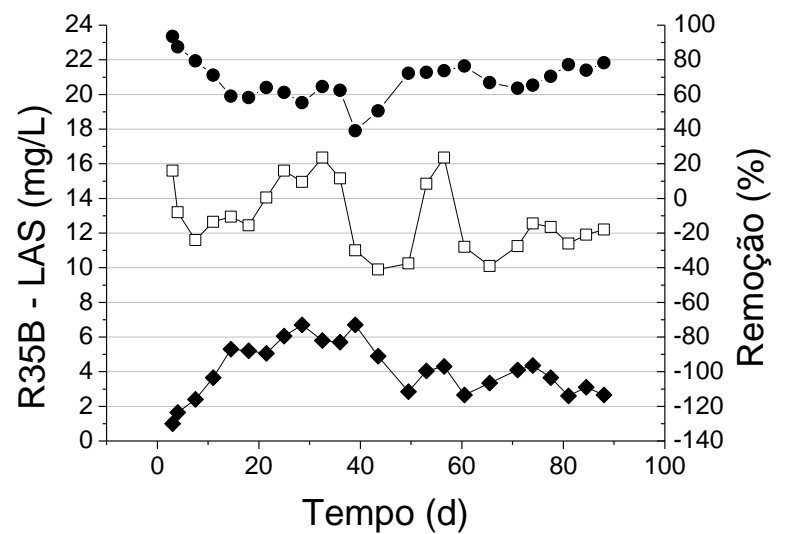

(b)

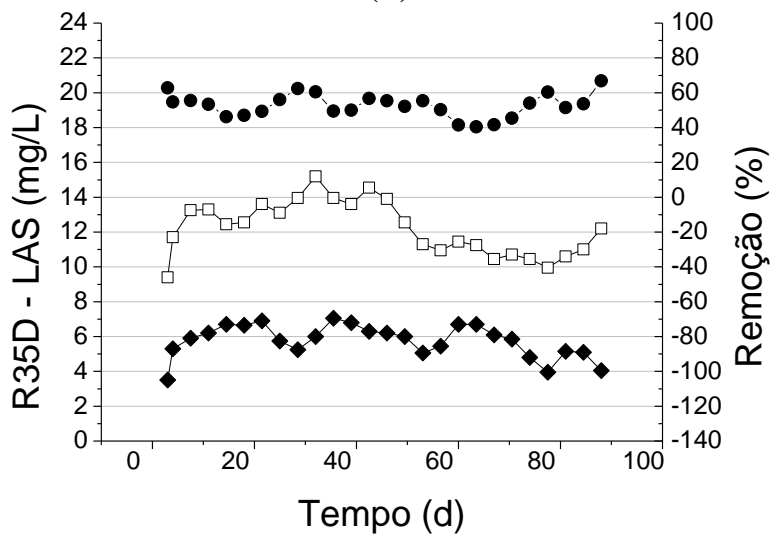

(d)

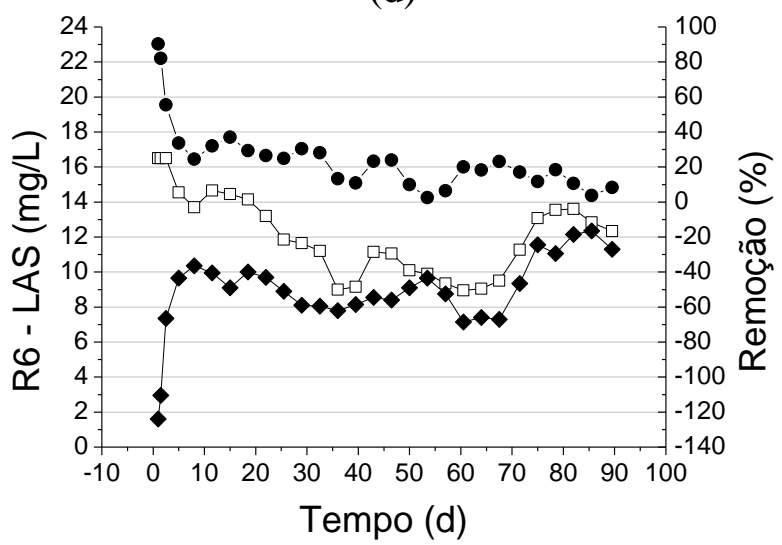

(f)

Figura 5.19: Variação temporal de LAS afluente $(\square)$, efluente $(\bullet)$ e remoção $(\bullet)$ nos reatores $R_{35 A}(a), R_{35 B}(b), R_{35 C}(c), R_{35 D}(d), R_{B C S}(e), R_{6}(f)$ e $R_{80}(g)$ 
Para correlacionar o tempo necessário para equilibrar adsorção e degradação de LAS com as concentrações de biomassa aplicadas, ajustou-se a concentração de LAS efluente dos primeiros dias de operação à sigmoide de Boltzmann $(y=A 2+(A 1-A 2) /(1+\exp ((x-x 0) / d x)))$ (Figura 5.20). Foram ajustados apenas os dados dos primeiros 20-70 dias, em virtude das oscilações de concentrações afluente e efluente de LAS de toda operação resultarem em redução do coeficiente de determinação $\left(\mathrm{R}^{2}\right)$. Apesar da variação de concentração de LAS afluente observada em diferentes períodos da operação de cada reator, verificou-se a maior susceptibilidade à mudança nas concentrações de LAS efluente após o equilíbrio entre adsorção e degradação de LAS. Nas sigmoides de Boltzmann obtidas, observou-se decréscimo da elongação da curva (coeficiente $d x$ ), de 8,8 para 1,3, em menores concentrações de biomassa, evidenciando a redução do tempo para equilíbrio entre adsorção e degradação de LAS. Dessa forma, a redução da concentração de biomassa implicou em menor tempo para equilíbrio entre adsorção e degradação de LAS. 


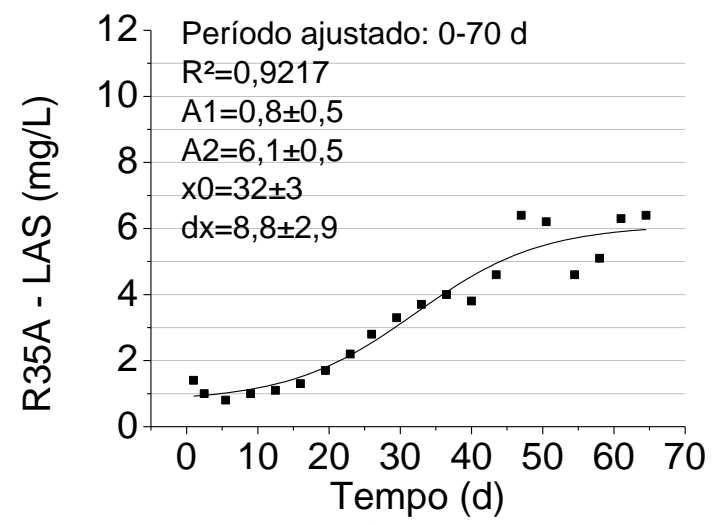

(a)

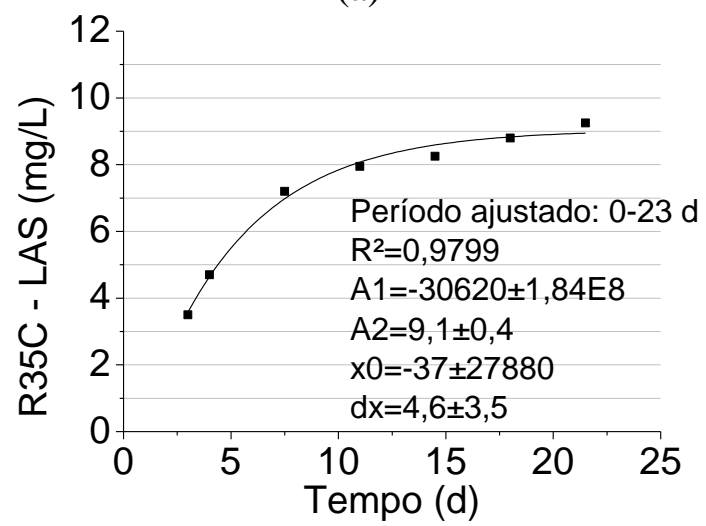

(c)

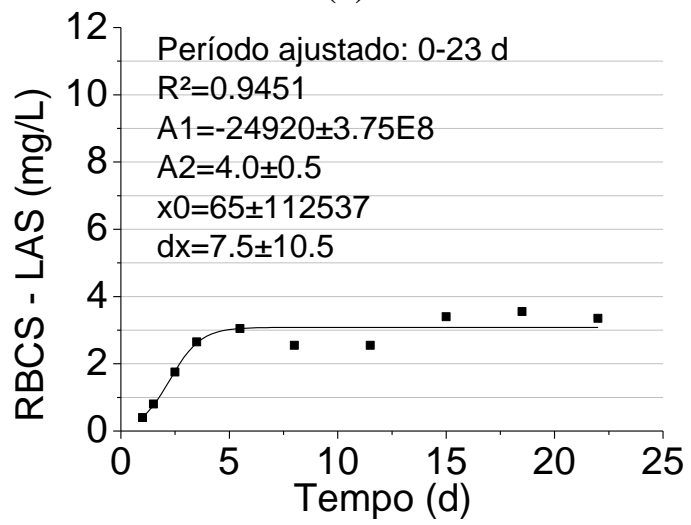

(e)

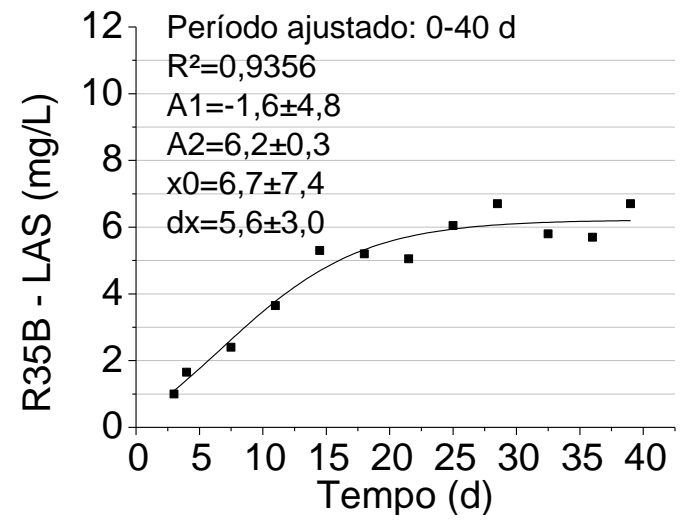

(b)

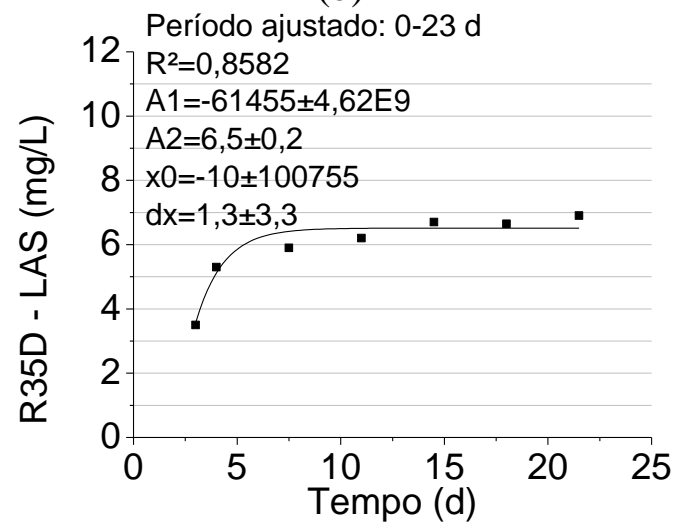

(d)

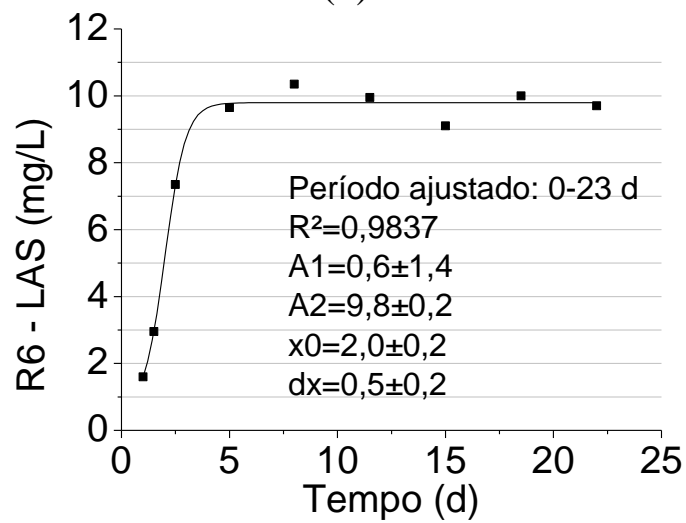

(f)

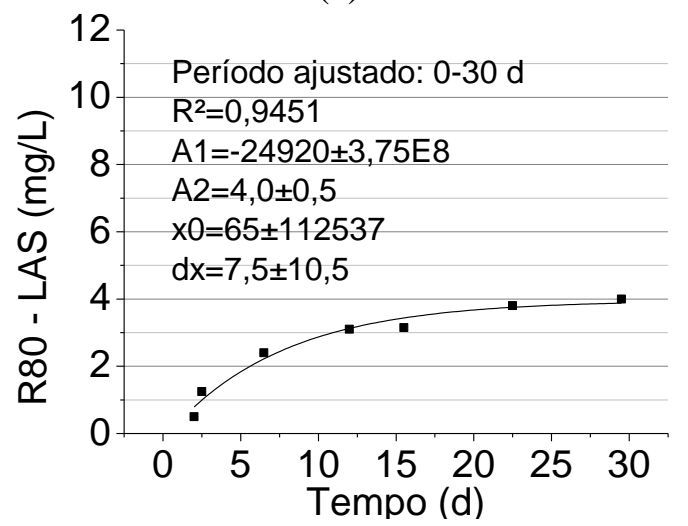

(g)

Figura 5.20: Concentrações de LAS efluente dos reatores $R_{35 \mathrm{~A}}(\mathrm{a}), \mathrm{R}_{35 \mathrm{~B}}$ (b), $R_{35 \mathrm{C}}(\mathrm{c}), \mathrm{R}_{35 \mathrm{D}}$ (d), $\mathrm{R}_{\mathrm{BCS}}(\mathrm{e}), \mathrm{R}_{6}(\mathrm{f})$ e $\mathrm{R}_{80}(\mathrm{~g})$, ajustadas à sigmoide de Boltzmann 
Observou-se concentração de LAS adsorvido na biomassa entre 33 e 47 mg/g ST (reatores $R_{35 B}, R_{35 C}$ e $R_{35 D}$ : Tabela 5.7), com exceção do reator $R_{35 A}$, que apresentou a menor concentração de LAS adsorvido (16,7 mg/g ST). Essa menor concentração de LAS adsorvido na biomassa foi relacionada com a maior quantidade de biomassa do reator $R_{35 \mathrm{~A}}$, uma vez que a manta de lodo preenchia praticamente todo o corpo do reator. Além disso, foram observadas bolhas de biogás na manta de lodo, que reduziram o contato do surfactante com a biomassa (Figura 5.21).

Tabela 5.7: Concentração de LAS adsorvido no inóculo e na biomassa ao final da operação

\begin{tabular}{lc}
\hline & $\begin{array}{c}\text { Concentração de LAS adsorvido } \\
\text { na biomassa }(\mathrm{mg} / \mathrm{g} \mathrm{ST})\end{array}$ \\
\hline Inóculo (inicial) & $0,4 \pm 0,1$ \\
$\mathrm{R}_{35 \mathrm{~A}}$ & $16,7 \pm 0,5$ \\
$\mathrm{R}_{35 \mathrm{~B}}$ & $39,6 \pm 1,0$ \\
$\mathrm{R}_{35 \mathrm{C}}$ & $46,6 \pm 2,9$ \\
$\mathrm{R}_{35 \mathrm{D}}$ & $33,2 \pm 0,7$ \\
$\mathrm{R}_{\mathrm{BCS}}$ & $37,1 \pm 0,4$ \\
$\mathrm{R}_{6}$ & $27,8 \pm 3,5$ \\
$\mathrm{R}_{80}$ & $48,4 \pm 0,5$ \\
\hline
\end{tabular}

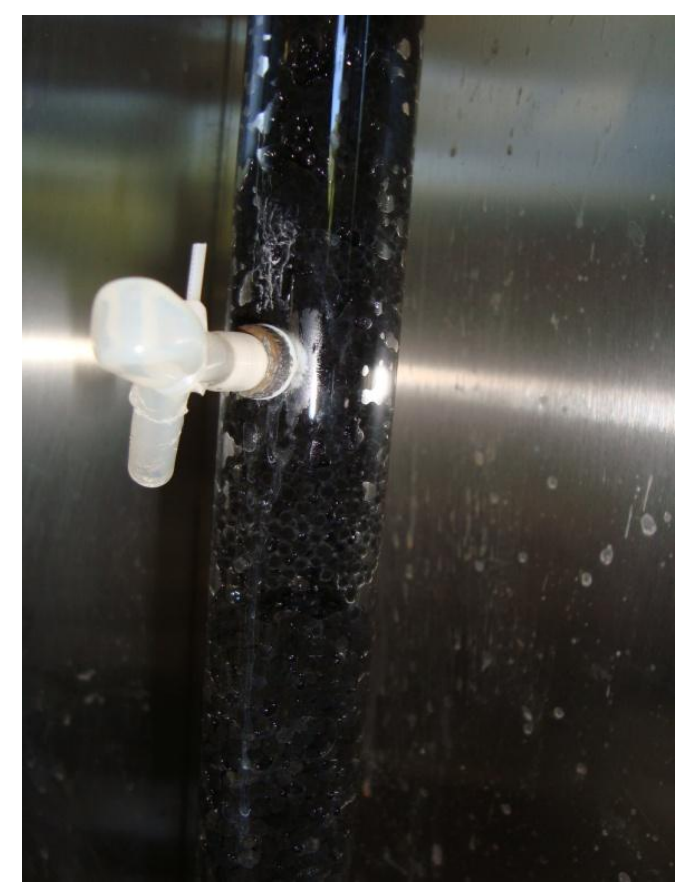

Figura 5.21: Manta de lodo no ponto de amostragem PA2 do reator $R_{35 A}$ 
Mediante balanço de massa de LAS, observou-se eficiência de degradação variando entre 37 e $53 \%$, nos reatores variando biodisponibilidade de $L A S\left(R_{35 A}, R_{35 B}, R_{35 C}\right.$ e $R_{35 D}$; Tabela 5.6). Foram verificadas duas tendências em relação à degradação de LAS: em torno de $40 \%$, para concentração de biomassa maior que 5,9 g ST/L ( $\mathrm{R}_{35 \mathrm{~A}}$ e $\left.\mathrm{R}_{35 \mathrm{~B}}\right)$; e em torno de 50\% para concentração de biomassa menor que 2,3 g ST/L ( $\mathrm{R}_{35 \mathrm{C}}$ e $\mathrm{R}_{35 \mathrm{D}}$ ) (Tabela 5.6; p. 74). A menor eficiência de degradação para reatores com concentração de biomassa maior que 5,9 g ST/L ( $R_{35 \mathrm{~A}}$ e $\mathrm{R}_{35 \mathrm{~B}}$ ) atribuiu-se à parcela de LAS adsorvido na biomassa (entre 29 e 34\%). Nos reatores com concentração de biomassa menor que 5,9 g ST/L $\left(\mathrm{R}_{35 \mathrm{C}}\right.$ e $\left.\mathrm{R}_{35 \mathrm{D}}\right)$ a parcela adsorvida correspondeu a valores entre 7 e $13 \%$.

Todavia, a variação das eficiências de degradação de LAS foi de $16 \%$, pouco maior que a observada (5-8\%) devido à redução da concentração de sólidos de $20 \mathrm{~g} \mathrm{ST/L}$ para 11 g ST/L, em reator CSTR (HAGGENSEN et al., 2002; ANGELIDAKI et al., 2004). Atribuiuse essa variação na degradação de LAS aos efeitos contrastantes da variação da biodisponibilidade de LAS nas parcelas efluente e adsorvida. À medida que foi reduzida a concentração de biomassa, obteve-se aumento da parcela efluente (de 28 para 47\%) e redução da parcela adsorvida (de 33 para 6\%) (Figura 5.18 e Tabela 5.6, p. 74). Dessa forma, observou-se pequeno aumento na degradação de LAS à medida que se aumentava sua biodisponibilidade. Esse pequeno aumento foi evidenciado pelo coeficiente angular $(0,487)$ obtido da regressão linear dos dados de carga e degradação específica de LAS nos reatores $\mathrm{R}_{35 \mathrm{~A}}, \mathbf{R}_{35 \mathrm{~B}}, \mathrm{R}_{35 \mathrm{C}}$ e $\mathrm{R}_{35 \mathrm{D}}$ (Figura 5.22), resultando na seguinte equação $\left(\mathrm{R}^{2}=0,9903 ; p<0,05\right)$ :

$$
\text { Degradação específica de } L A S=0,487 * \text { Carga específica de } L A S-0,05 \quad \text { (Equação 5.1) }
$$




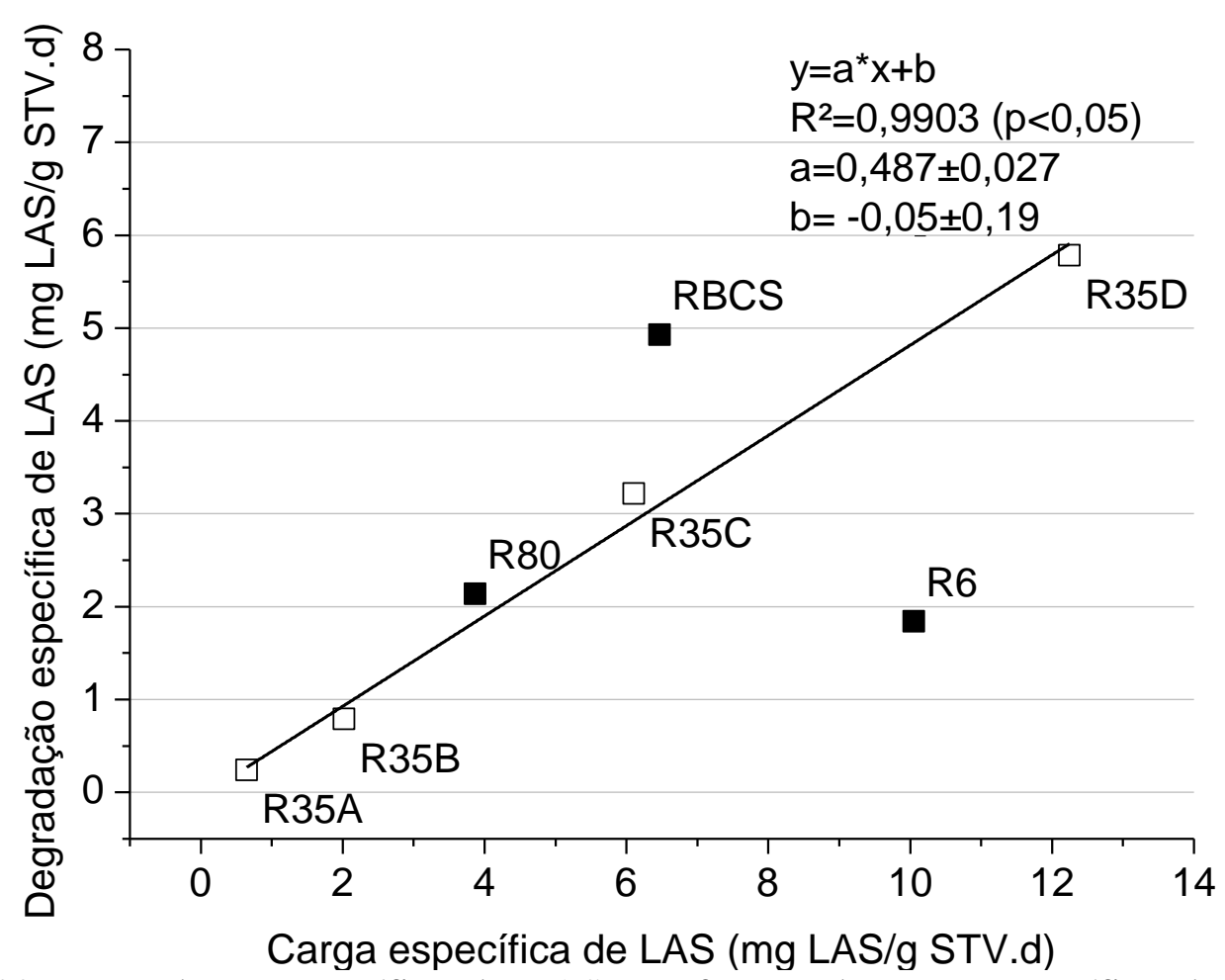

Figura 5.22: Degradação específica de LAS em função da carga específica de LAS nos reatores $R_{35 A}, R_{35 B}, R_{35 C}, R_{35 D}(\square), R_{B C S}, R_{6}$ e $R_{80}(\boldsymbol{m})$. Realizou-se regressão linear dos dados dos reatores $R_{35 A}, R_{35 B}, R_{35 C}$ e $R_{35 D}\left(R^{2}=0,9903\right)$

\subsubsection{Influência do TDH}

Observou-se menor tempo para equilíbrio entre adsorção e degradação de LAS, com a redução de TDH de 80 h para 6 h. A partir do ajuste das concentrações efluente de LAS à sigmoide de Boltzmann no reator $\mathrm{R}_{6}$ (TDH 6 h) obteve-se elongação da curva (coeficiente $d x$ ) de 0,5 (Figura 5.20, p. 77). Comparando com $\mathrm{R}_{35 \mathrm{~B}}$ (com TDH de 35 h e concentração de biomassa próxima à do reator $\mathrm{R}_{6}$ ), observou-se maior elongação da curva (coeficiente $d x$ de 5,6 para o reator $\left.\mathrm{R}_{35 \mathrm{~B}}\right)$. Aplicando TDH de $80 \mathrm{~h}\left(\mathrm{R}_{80}\right)$ observou-se maior elongação da curva $(d x)$, com valor 7,5. Apesar do alto erro padrão desse parâmetro $(10,5)$, inferiu-se que o aumento do TDH resultou em maior tempo para equilíbrio entre adsorção e degradação de LAS. Em virtude do aumento da taxa de LAS aplicada, de 4,2 mg/L.d (R R0$_{80}$ TDH 80 h) para 
51 mg/L.d ( R $_{6}$; TDH 6 h), obteve-se equilíbrio entre adsorção e degradação de LAS em menor tempo.

A menor eficiência de degradação de LAS (18\%) foi observada no reator com TDH $6 \mathrm{~h}$, indicando que o tempo aplicado não foi suficiente para as reações envolvidas na degradação do surfactante. A baixa biotransformação de LAS foi corroborada pela elevada parcela de surfactante no efluente (78\%). A parcela adsorvida no reator $\mathrm{R}_{6}$ foi baixa devido à grande quantidade de LAS adicionada $\left(3.027 \mathrm{mg}\right.$ ). Comparada com o reator $\mathrm{R}_{35 \mathrm{~B}}$, que possuía concentração de biomassa próxima (Tabela 4.4 e Tabela 4.5, p. 33), observou-se pouca diferença entre as quantidades adsorvidas na biomassa (153 mg no reator $\mathrm{R}_{35 \mathrm{~B}}$ e $102 \mathrm{mg}$ no reator $\mathrm{R}_{6}$ ) (Tabela 5.6).

Em TDH de 80 h, observou-se eficiência de degradação de LAS ( $\left.\mathrm{R}_{80}: 55 \%\right)$ pouco maior que a observada nos reatores variando a biodisponibilidade, em TDH de $35 \mathrm{~h}\left(\mathrm{R}_{35 \mathrm{~A}}\right.$, $\left.\mathrm{R}_{35 \mathrm{~B}}, \mathrm{R}_{35 \mathrm{C}}, \mathrm{R}_{35 \mathrm{D}}: 37-53 \%\right)$. A eficiência de degradação obtida para o reator $\mathrm{R}_{80}(55 \%)$ foi atribuída à menor quantidade de LAS adicionado $(237 \mathrm{mg})$, resultando em maior parcela no efluente $(22 \%)$ e adsorvida na biomassa (23\%). Apesar da baixa concentração efluente (2 mg/L) (Tabela 5.5, p. 69), a taxa de LAS aplicada no reator $\mathrm{R}_{80}$ foi de $4,2 \mathrm{mg} / \mathrm{L} . \mathrm{d}$, cerca de metade da taxa de LAS aplicada em TDH de 35 h (8,4-9,1 mg/L.d) (Tabela 5.6, p. 74).

Considerando a influência da biodisponibilidade de LAS, comparou-se a degradação específica de LAS nos reatores $\mathrm{R}_{6}$ e $\mathrm{R}_{80}$ com a equação 5.1, definida para TDH de $35 \mathrm{~h}$ (Figura 5.22, p. 80). Em TDH de 80 h $\left(\mathrm{R}_{80}\right)$ observou-se degradação específica de LAS pouco maior que o esperado pela equação 5.1 (16\%). Todavia, em TDH de $6 \mathrm{~h}\left(\mathrm{R}_{6}\right)$ observou-se menor atividade de degradação específica que o previsto pela equação 5.1 (cerca de 60\%).

Comparando os resultados obtidos no presente estudo com trabalhos anteriores, observou-se decréscimo da degradação de LAS em reatores com TDH menor que 35 h. Em reator anaeróbio de leito granular expandido (EGSB), observou-se decréscimo da remoção de 
LAS de 64-74\% para 48\%, com a redução do TDH de 32 h para 26 h (DELFORNO et al., 2012). Comparando a degradação específica de $\mathrm{R}_{\mathrm{UASB}}$ (item 5.2, p. 58) com a equação 5.1, observou-se valor menor (39\%) em relação ao esperado em virtude do menor TDH aplicado, de 24 h (Tabela 5.8). Em RAHLF (DUARTE, 2006), a degradação específica de LAS foi menor que aquela obtida por meio da equação 5.1 (26\%), devido ao menor TDH (12 h) (Tabela 5.8).

Tabela 5.8: Comparação de degradação específica de LAS

\begin{tabular}{lccccccc}
\hline Reator & $\begin{array}{c}\text { TDH } \\
\text { (h) }\end{array}$ & $\begin{array}{c}\text { LAS } \\
(\mathrm{mg} / \mathrm{L})\end{array}$ & $\begin{array}{c}\text { Carga esp. } \\
\text { de LAS } \\
\text { (mg/g STV.d) }\end{array}$ & $\begin{array}{c}\text { Degradação } \\
\text { esp. de LAS } \\
\text { (mg/g STV.d) }\end{array}$ & $\begin{array}{c}\text { Degradação } \\
\text { esp. de LAS } \\
\text { (eq. 5.1) } \\
\text { (mg/g STV.d) }\end{array}$ & $\begin{array}{c}\text { Variação } \\
(\%)\end{array}$ & Ref. \\
\hline R $_{\text {UASB }}$ & 24 & 14 & 3,24 & 0,93 & 1,53 & -39 & $\begin{array}{c}\text { Presente } \\
\text { estudo }\end{array}$ \\
RAHLF & 12 & 14 & 2,44 & 0,85 & 1,13 & -26 & $\begin{array}{c}\text { Duarte } \\
\text { (R1) }\end{array}$ \\
Bateladas & & & & & & & (2006) \\
sequenciais & & & & & & & Duarte et \\
$\quad$ Etapa II & 24 & 22 & 9,80 & 3,3 & 4,72 & -30 & al. \\
Etapa III & 24 & 22 & 6,80 & 1,7 & 3,26 & -49 & (2010a) \\
Etapa IV & 24 & 22 & 8,33 & 4,4 & 4,01 & 11 & \\
\hline
\end{tabular}

Duarte et al. (2010a) observaram menor degradação específica de LAS, empregando reator em bateladas sequenciais, com TDH de 24 h. Nesse estudo, verificou-se degradação específica de LAS menor que aquela calculada por meio da equação 5.1 nas Etapas II (30\%) e III (49\%) (Tabela 5.8). Na Etapa III do estudo de Duarte et al. (2010a), observou-se menor remoção de DQO, indicando a possibilidade de aumento de ácidos voláteis no efluente. Relacionou-se a maior variação na degradação específica de LAS (49\%) na Etapa III do estudo de Duarte et al. (2010a) com a possibilidade de aumento de ácidos voláteis no efluente, que é prejudicial à degradação de surfactante (LOBNER et al., 2005). Na Etapa IV do estudo de Duarte et al. (2010a), verificou-se degradação específica de LAS pouco maior que a esperada pela equação 5.1 (11\%), devido à alimentação do reator sem co-substratos. Ressaltase que em virtude do menor TDH do reator em bateladas sequenciais $(24 \mathrm{~h})$ em relação ao da 
equação $5.1(35$ h) esperava-se menor degradação específica. Dessa forma, a maior degradação específica de LAS na Etapa IV do estudo de Duarte et al. (2010a) indicou maior influência da retirada de co-substratos que o TDH na degradação de LAS.

A variação do TDH de 6 h a 80 h resultou em degradação de LAS variando entre 18 e 55\%. A comparação com os estudos supracitados (Tabela 5.8) evidenciou a relação entre TDH e degradação de LAS, exceto na situação em que o reator foi alimentado sem cosubstratos. Todavia, o aumento da degradação de surfactante foi limitado pela redução da taxa de LAS aplicada em TDH maior que $35 \mathrm{~h}$.

\subsubsection{Influência da concentração de co-substratos}

A maior eficiência de degradação de LAS (76\%) foi observada no reator alimentado com baixa concentração de co-substratos ( $\left.\mathrm{R}_{\mathrm{BCS}}\right)(\mathrm{COE}:$ 0,03 g DQO/g STV.d). Contribuíram para essa eficiência a baixa concentração de biomassa (1,6 g ST/L), que resultou na menor parcela de LAS adsorvido (8\%), e a pequena parcela no efluente (16\%). Observou-se menor tempo para equilíbrio entre adsorção e degradação de LAS (coeficiente $d x=0,7$; sigmoide de Boltzmann da Figura 5.20, p. 77) devido à baixa concentração de biomassa no reator $\mathrm{R}_{\mathrm{BCS}}$ $(1,6 \mathrm{~g} \mathrm{ST} / \mathrm{L})$.

Devido à baixa concentração de SST efluente do reator $\mathrm{R}_{\mathrm{BCS}}(6 \mathrm{mg} \mathrm{SST} / \mathrm{L})$ observouse menor liberação de biomassa do reator, indicando que a carga orgânica específica de 0,03 g DQO/g STV.d foi favorável à manutenção da comunidade microbiana.

Comparando com a equação 5.1, verificou-se que a degradação específica de LAS foi cerca de $60 \%$ maior em relação ao esperado (Figura 5.22, p. 80). Como o TDH aplicado no reator $\mathrm{R}_{\mathrm{BCS}}$ e aquele aplicado na equação 5.1 foram similares $(35 \mathrm{~h})$, essa maior degradação 
específica de LAS evidenciou a maior influência da concentração de co-substratos na degradação do surfactante.

As maiores eficiências de degradação de LAS foram obtidas em reator UASB (85\%) (SANZ et al., 2003) e em reator anaeróbio de leito fluidificado (81-99\%) (OLIVEIRA et al., 2010). No reator UASB atribuiu-se a maior degradação de LAS (85\%) à retirada de cosubstratos da alimentação (SANZ et al., 2003). No reator anaeróbio de leito fluidificado, observou-se maior eficiência de degradação de LAS (81-99\%) em virtude da transferência de massa e diluição do afluente proporcionado pela alta vazão de recirculação $(16-30 \mathrm{~L} / \mathrm{h})$ (OLIVEIRA et al., 2010). Além disso, observou-se baixa concentração de ácidos voláteis (1216 mg HAc/L) no reator anaeróbio de leito fluidificado (OLIVEIRA et al., 2010), corroborando a relação entre degradação de LAS e concentração de co-substratos (representado pelos ácidos voláteis).

A baixa concentração de co-substratos (COE: 0,03 g DQO/g STV.d ) aplicada no reator $\mathrm{R}_{\mathrm{BCS}}$ resultou em consumo mais rápido de co-substratos. Em virtude do consumo mais rápido de co-substratos no reator $\mathrm{R}_{\mathrm{BCS}}$, observou-se maior degradação de LAS indicando o uso do surfactante como fonte alternativa de carbono pela comunidade microbiana.

\subsubsection{Interação entre biodisponibilidade de LAS, TDH e concentração de co-substratos na degradação de LAS}

Segundo a matriz de correlação (Tabela 5.9), a variável que apresentou maior influência na degradação de LAS foi a carga orgânica específica (COE). O coeficiente de correlação entre degradação de LAS e COE foi de $-0,835(p<0,05)$, indicando associação negativa, ou seja, a degradação foi inversamente proporcional à variação de COE (Figura $5.23 \mathrm{c})$. 
Tabela 5.9: Matriz de correlação entre concentração de sólidos totais (ST), TDH, carga orgânica específica (COE) e degradação de LAS

\begin{tabular}{llcccc}
\hline & & ST & TDH & COE & Degradação de LAS \\
\hline ST & Correlação Person & 1 & & & \\
TDH & Significância (bicaudal) & & & & \\
& Correlação Person & $-0,263$ & 1 & & \\
COE & Significância (bicaudal) & 0,569 & & & \\
& Correlação Person & 0,686 & $-0,609$ & 1 & \\
Degradação & Significância (bicaudal) & 0,089 & 0,147 & & \\
de LAS & Correlação Person & $-0,492$ & 0,534 & $-0,835$ & 1 \\
\hline
\end{tabular}

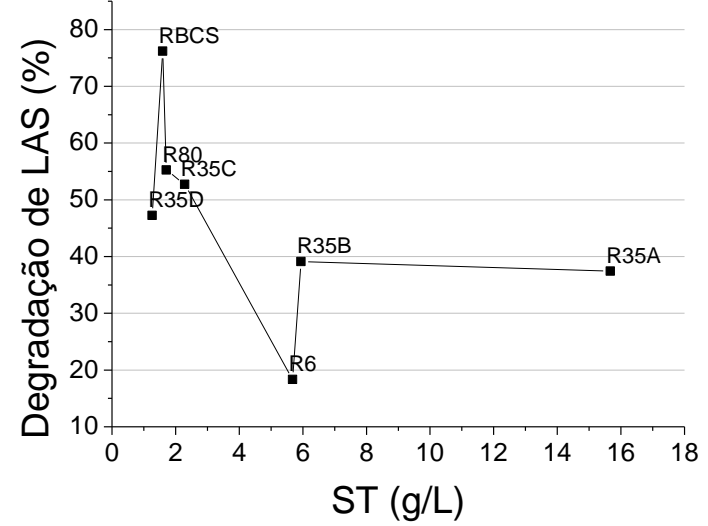

(a)

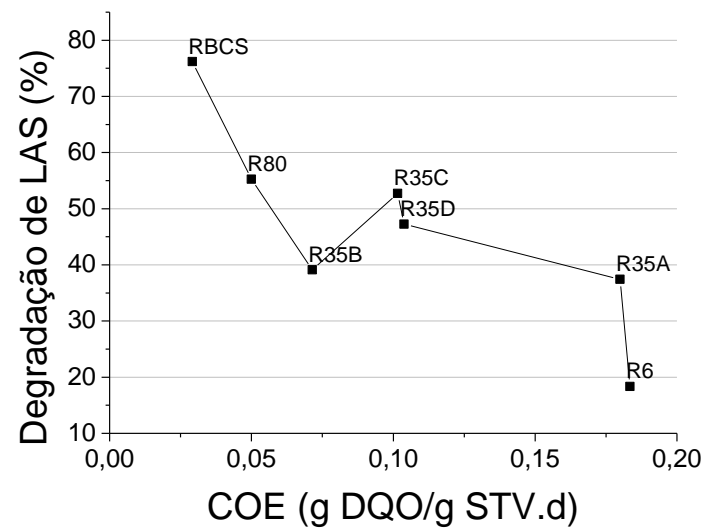

(c)

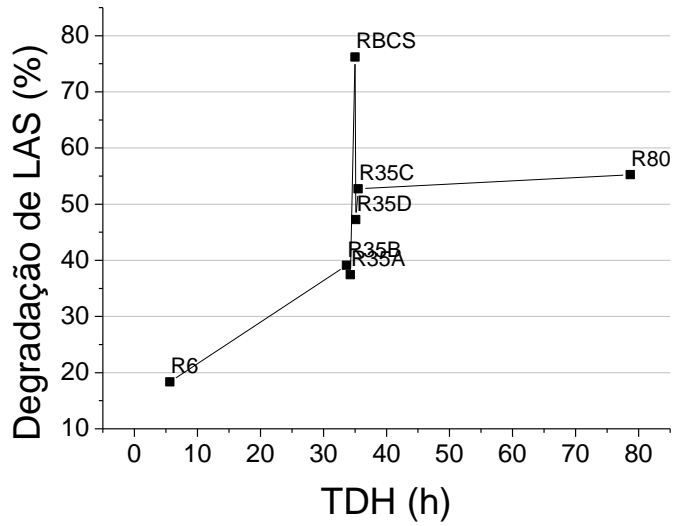

(b)

Figura 5.23: Degradação de LAS em função da concentração de ST (a), TDH (b) e carga orgânica específica (COE) (c)

Entre TDH e degradação de LAS, o coeficiente de correlação de $0,534(p=0,217)$ indicou associação positiva. Observou-se aumento da degradação de LAS à medida que se aumentou o TDH com exceção da eficiência do reator $\mathrm{R}_{\mathrm{BCS}}$ (concentração de co-substrato 
baixa), cujo aumento na degradação foi bem acima do restante (Figura 5.23b). Além disso, observou-se menor incremento da degradação de LAS em TDH maior que 35 h, devido à redução da taxa de LAS aplicada.

Observou-se correlação negativa entre degradação de LAS e concentração de sólidos totais (representando a biodisponibilidade de LAS), com coeficiente de $-0,492(p=0,262)$. Verificou-se menor degradação de LAS à medida que se aumentava a concentração de ST (Figura 5.23a). Na relação entre concentração de ST e degradação de LAS, foram exceções os reatores com TDH de 6 h ( $\mathrm{R}_{6}$, degradação menor que a esperada: 18\%) e com baixa concentração de co-substrato ( $\mathrm{R}_{\mathrm{BCS}}$, degradação maior que a esperada: $76 \%$ ).

Considerando que o valor $p$ dos coeficientes de correlação entre degradação de LAS, TDH e ST foi alto $(>0,21)$, indicando pouca confiança, determinou-se outra matriz de correlação para inferir qual foi a variável que apresentou maior influência na degradação de LAS depois da COE. Para determinar qual variável, TDH ou ST, apresentou maior influência na degradação de LAS, excluíram-se os dados do reator $\mathrm{R}_{\mathrm{BCS}}$ (concentração baixa de cosubstrato). Nessa matriz de correlação, o maior coeficiente de correlação foi entre degradação de LAS e TDH $(0,819 ; p<0,05)$, demonstrando que, depois da COE, o TDH foi a variável que apresentou maior influência na degradação do surfactante.

\subsubsection{Variação espacial}

Observou-se consumo de ácidos orgânicos voláteis ao longo de todos os reatores, com redução de 57-1.143 mg HAc/L (afluente) para 0-53 mg HAc/L no efluente (Figura 5.24). No reator com TDH de 6 h ( $\left.\mathrm{R}_{6}\right)$, observou-se significativa produção de ácidos orgânicos voláteis na manta de lodo em virtude do aumento da concentração de 64 para 82 mg HAc/L. No reator 
$\mathrm{R}_{80}$, observou-se pouca variação da concentração de ácidos orgânicos voláteis a partir do ponto PA2, composta apenas pelo ácido butírico, em $16 \mathrm{mg} / \mathrm{L}$.

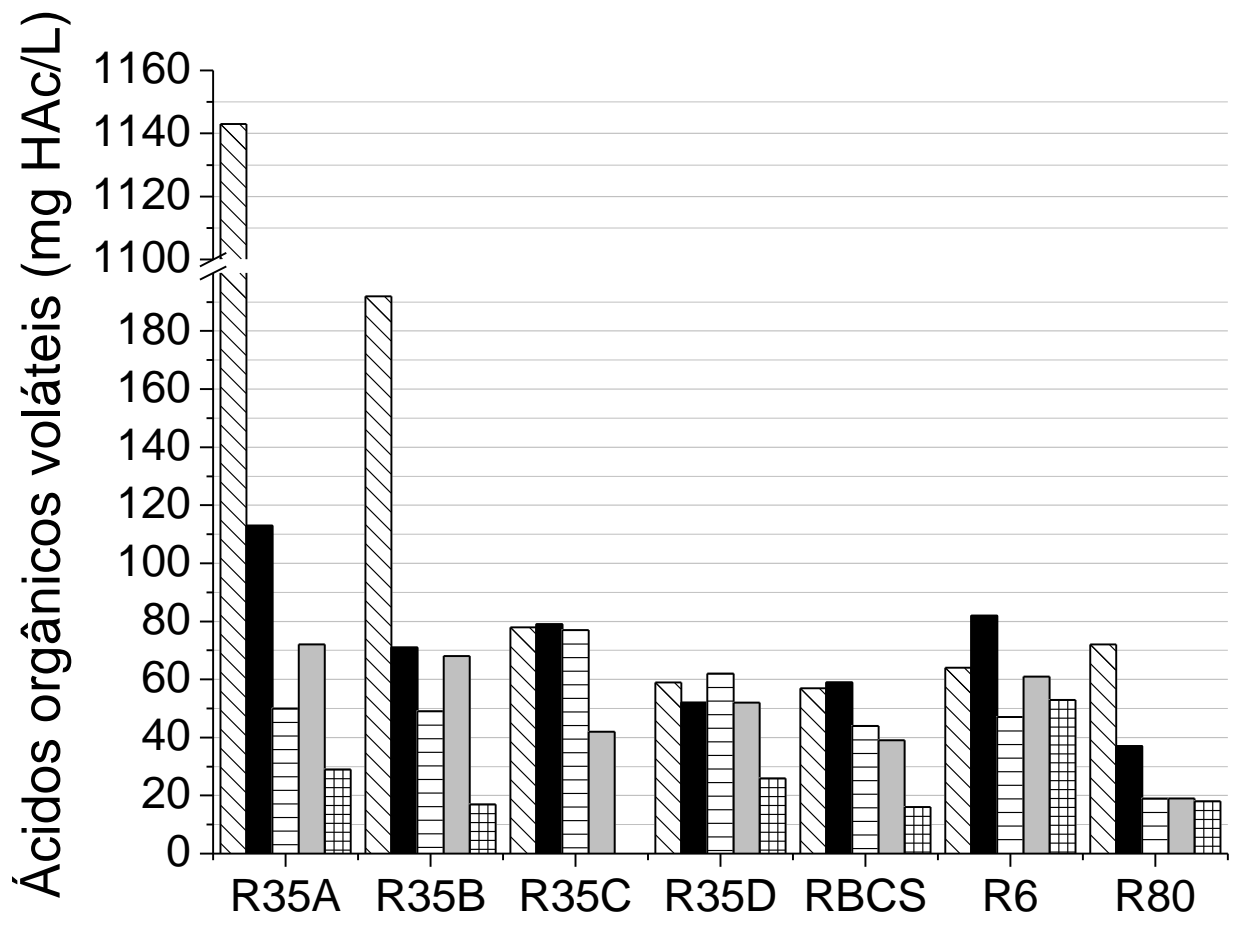

Figura 5.24: Variação espacial de ácidos orgânicos voláteis no afluente (\$), pontos PA1 (ם), PA2 (目), PA3 ( $\square$ ) e efluente (团)

Com exceção de $\mathrm{R}_{6}$, observou-se significativa remoção de LAS, de $20 \%$ a $53 \%$, no separador de fases (entre o ponto PA3 e efluente), enquanto, na manta de lodo (até o ponto PA3) observou-se remoção variando de 13 a 43\% (Figura 5.25). A remoção de LAS no separador de fases foi diretamente relacionada com a degradação do surfactante (regressão linear, $\left.\mathrm{R}^{2}=0,7946 ; p<0,05\right)$, sendo obtidas as maiores eficiências de degradação nos reatores com maior remoção no separador de fases $\left(\mathrm{R}_{\mathrm{BCS}}\right.$ e $\left.\mathrm{R}_{80}\right)$ (Figura 5.26). 


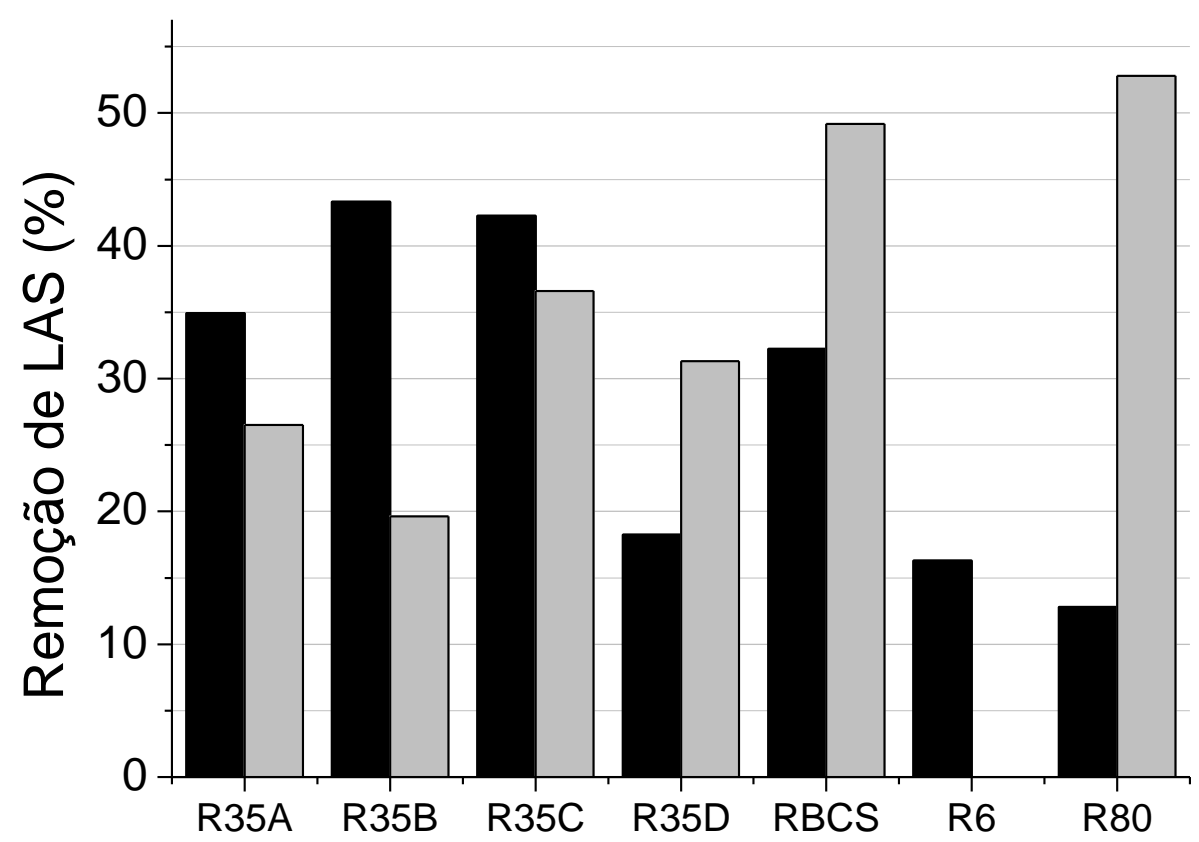

Figura 5.25: Remoção de LAS na manta de lodo ( $\square)$ e no separador de fases $(\square)$

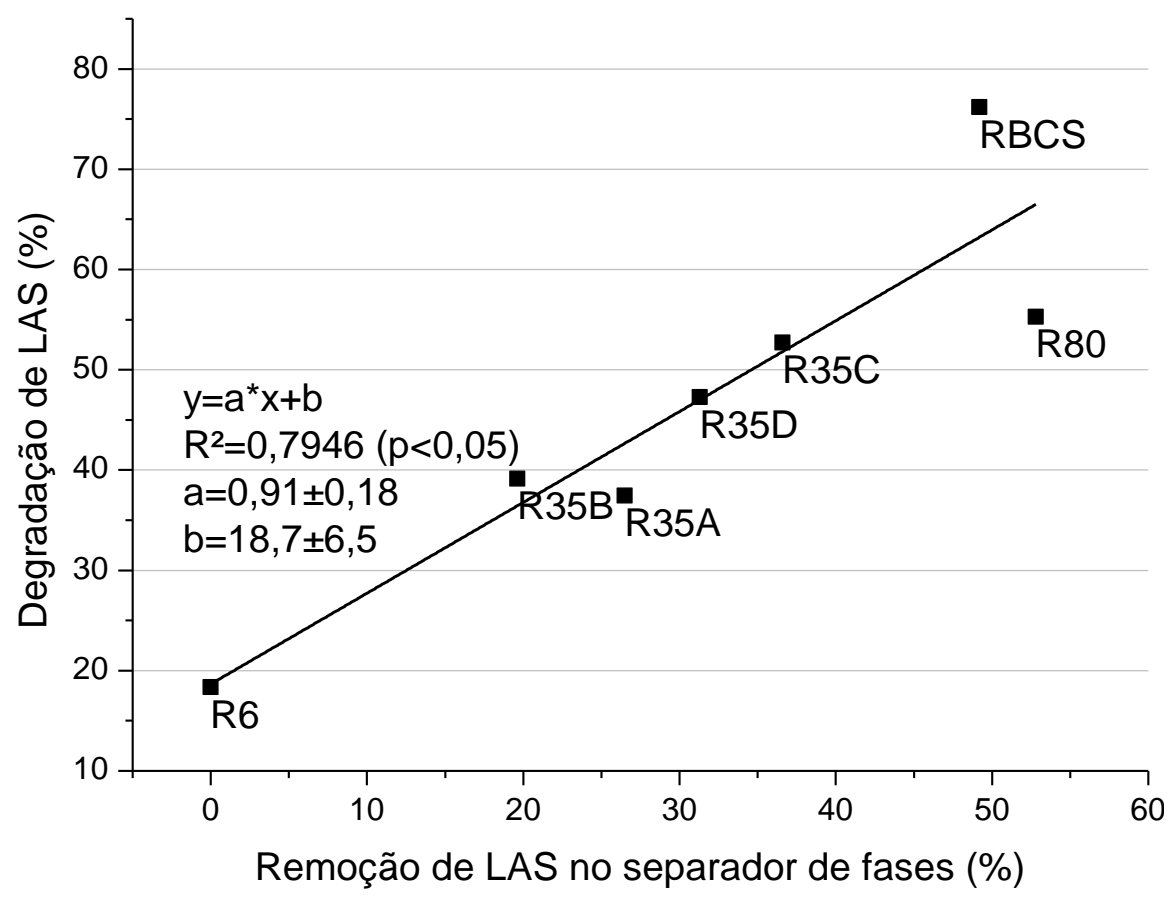

Figura 5.26: Relação entre remoção de LAS no separador de fases e degradação de LAS

Atribuiu-se a maior remoção de LAS no separador de fases a dois aspectos: a condição anaeróbia facultativa e a menor concentração de co-substratos nessa região. No ponto PA3 observou-se de 20 a 70 mg HAc/L de ácidos orgânicos voláteis, denotando menor concentração de co-substratos na região do separador de fases. Como observado no reator 
$\mathrm{R}_{\mathrm{BCS}}$, a menor concentração de co-substratos resultou em maior remoção de LAS. Além disso, observou-se relação linear negativa $\left(\mathrm{R}^{2}=0,8244 ; p<0,05\right)$ entre a remoção de LAS no separador de fases e a concentração de ácidos orgânicos voláteis no ponto PA3 (com exceção do reator $\mathrm{R}_{6}$ em que não foi observada remoção de surfactante) (Figura 5.27).

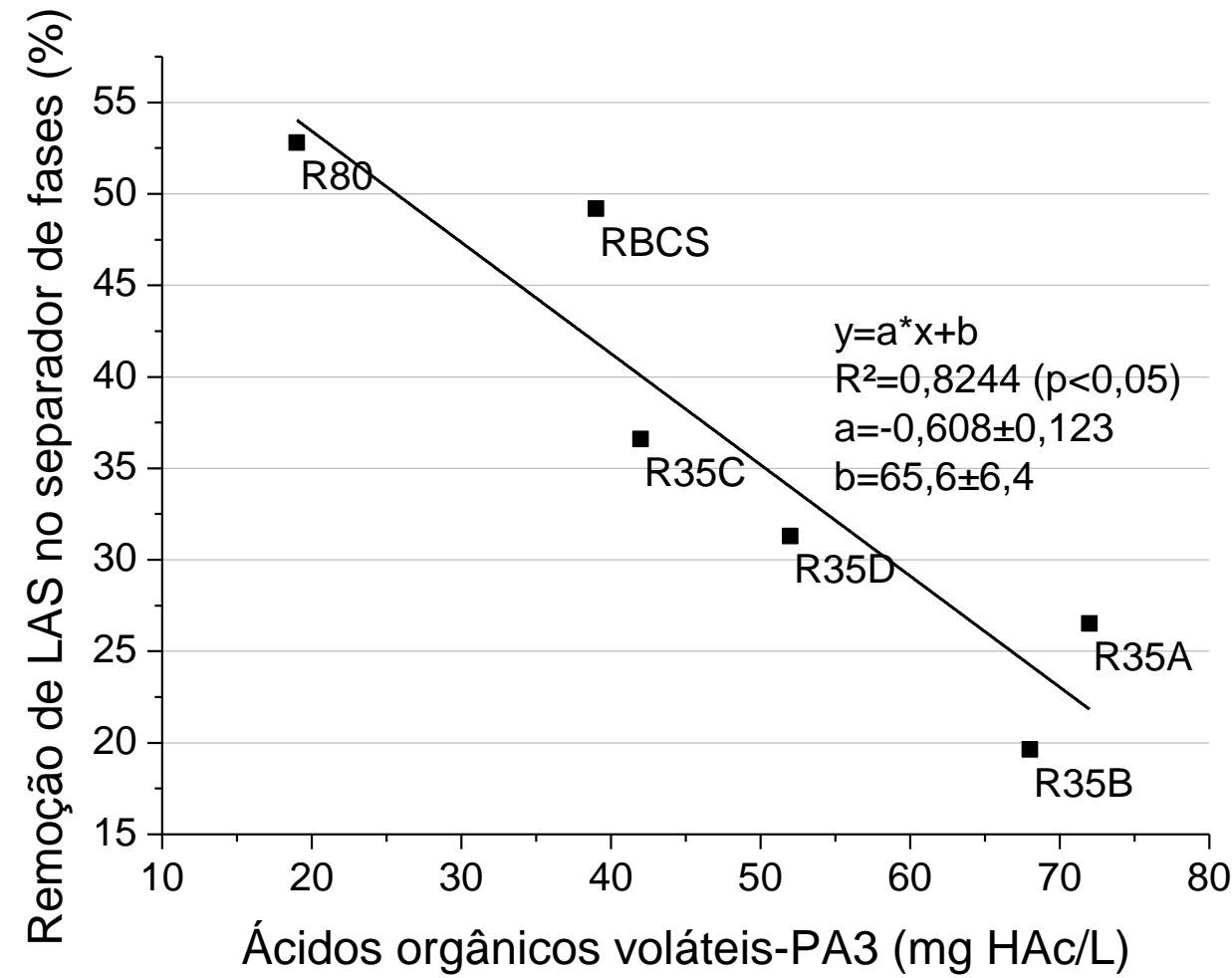

Figura 5.27: Remoção de LAS no separador de fases em função da concentração de ácidos orgânicos voláteis no ponto PA3

Com relação à condição anaeróbia facultativa, Larson et al.(1993) postularam sobre a necessidade de prévia exposição aeróbia para obter degradação de LAS em condição anaeróbia estrita. Os autores observaram degradação em condição anaeróbia estrita, somente, após incubação aeróbia durante 5-6 h, em virtude do uso de oxigênio para reação de $\omega$ oxidação (início da quebra da cadeia alquílica) (LARSON et al., 1993). Angelidaki et al. (2004), usando LAS com carbono marcado $\left(\mathrm{C}^{14}\right)$, verificaram que a maior parte do surfactante degradado foi convertido a dióxido de carbono $\left(\mathrm{CO}_{2}: 5,6 \%\right)$ e parcela desprezível foi convertida em metano $\left(\mathrm{CH}_{4}: 0,01 \%\right)$, em reator CSTR. 


\subsubsection{Caracterização microbiana}

Mediante análise de cluster do perfil das bandas padrões do DGGE para os domínios Archaea e Bacteria, verificou-se menor mudança nas comunidades microbianas da manta de lodo (Figura 5.28 e Figura 5.29). Observou-se maior variação dos coeficientes de similaridade na biomassa do separador de fases (Archaea: 29-86\%; Bacteria: 52-76\%) que na manta de lodo (Archaea: 70-90\%; Bacteria: 69-83\%).

Por meio da constatação da menor variação dos coeficientes de similaridade na manta de lodo pode-se inferir que a estrutura de grânulo protegeu a comunidade microbiana da variação das condições aplicadas em relação à biodisponibilidade de LAS, TDH e concentração de co-substratos. Em virtude desse arranjo adequadamente estruturado do grânulo, observou-se menor variação do coeficiente de similaridade entre o inóculo e as amostras da manta de lodo (Archaea: 70-93\%; Bacteria: 69-87\%) para as diferentes condições. 


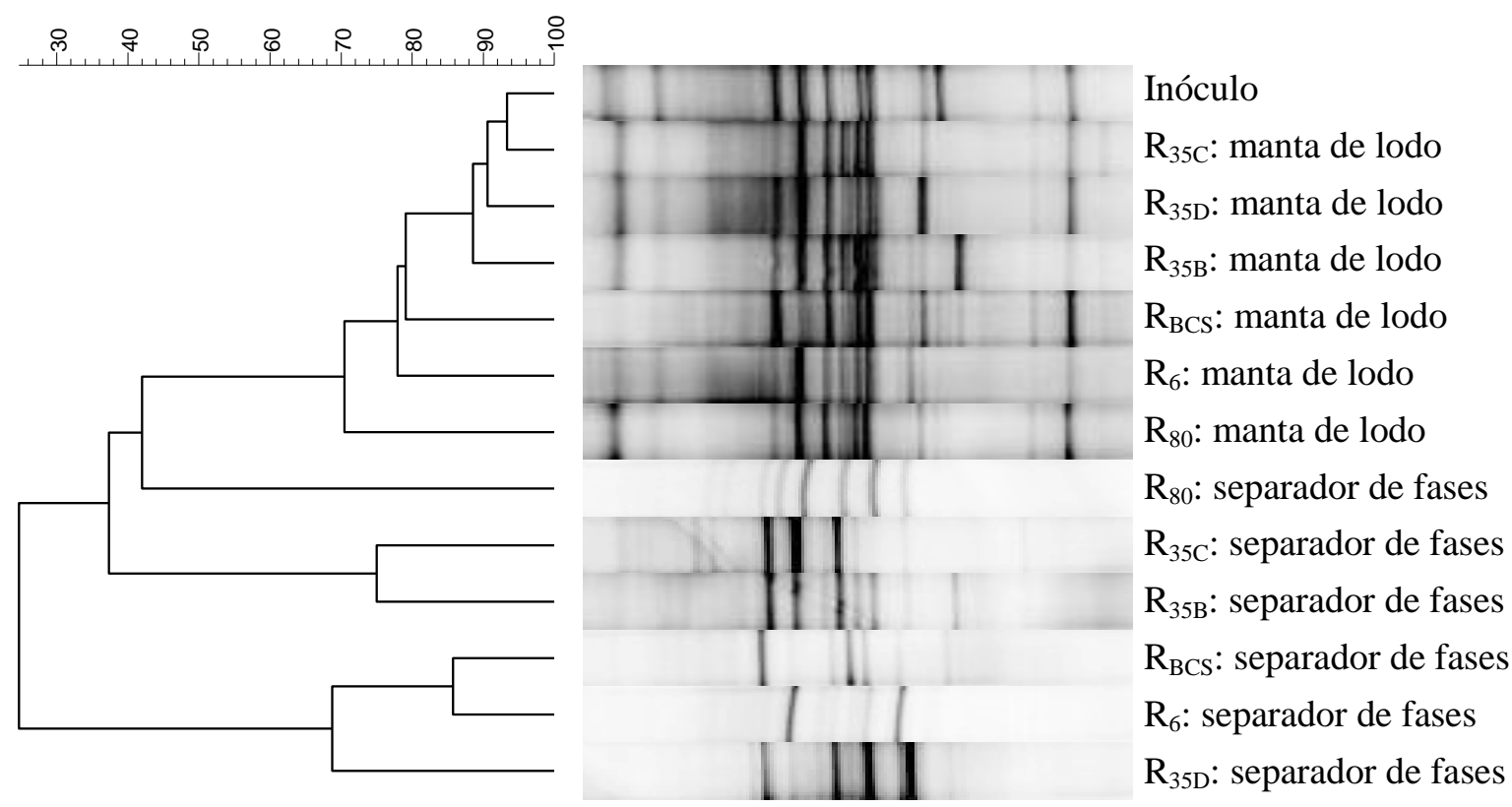

(a)
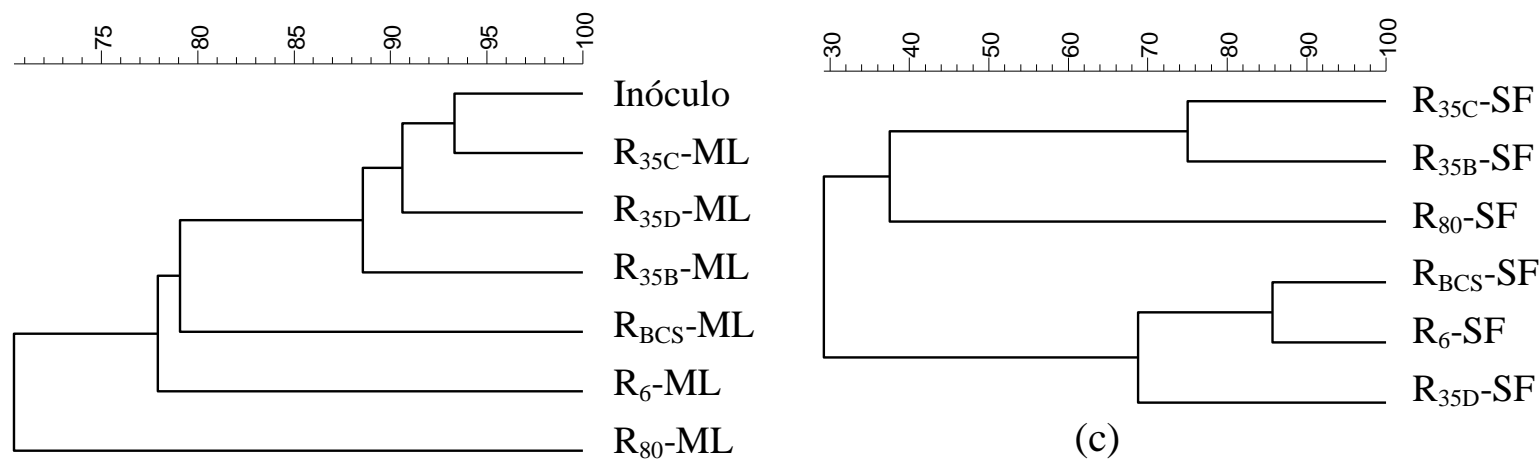

(b)

Figura 5.28: Análise de cluster (Dice, UPGMA) do perfil das bandas padrões do DGGE dos fragmentos do RNAr 16S para o domínio Archaea (a) de amostras do inóculo, manta de lodo (ML) (b) e biomassa do separador de fases (SF) (c) 

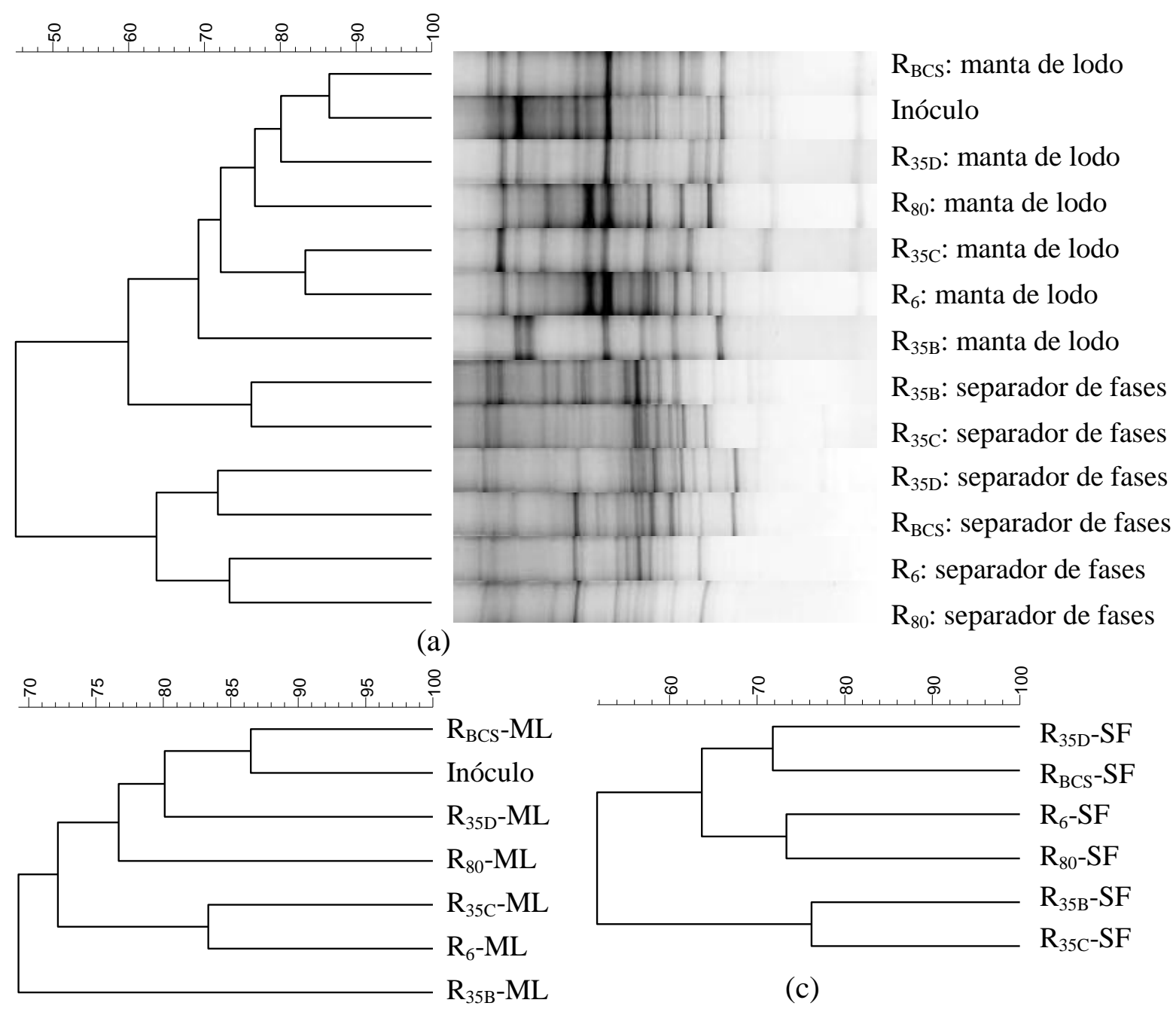

(b)

(c)

Figura 5.29: Análise de cluster (Dice, UPGMA) do perfil das bandas padrões do DGGE dos fragmentos do RNAr 16S para o domínio Bacteria (a) de amostras do inóculo, manta de lodo (ML) (b) e biomassa do separador de fases (SF) (c)

Em relação ao domínio Archaea nas amostras da manta de lodo, a variação de TDH e concentração de co-substratos resultou em coeficientes de similaridade menores (70-79\% nos reatores $\mathrm{R}_{6}, \mathrm{R}_{80}$ e $\mathrm{R}_{\mathrm{BCS}}$ ) que a variação de concentração de biomassa (89-90\%, nos reatores $\mathrm{R}_{35 \mathrm{~B}}, \mathrm{R}_{35 \mathrm{C}}$ e $\mathrm{R}_{35 \mathrm{D}}$ ). Além disso, verificou-se maior coeficiente de similaridade (89-93\%) do domínio Archaea entre o inóculo e amostras da manta de lodo dos reatores variando a concentração de biomassa $\left(\mathrm{R}_{35 \mathrm{~B}}, \mathrm{R}_{35 \mathrm{C}}\right.$ e $\left.\mathrm{R}_{35 \mathrm{D}}\right)$. Em relação ao domínio Bacteria, não foi verificada distinção clara entre as condições aplicadas e os coeficientes de similaridade, ou seja, entre inóculo e amostras da manta de lodo dos reatores $R_{35 \mathrm{D}}, \mathrm{R}_{80}$ e $\mathrm{R}_{\mathrm{BCS}}$ (variando 
concentração de biomassa, TDH e concentração de co-substratos, respectivamente) observouse coeficiente de similaridade de 76-86\%, enquanto, entre inóculo e amostras da manta de lodo dos reatores $R_{35 B}, R_{35 C}$ e $R_{6}$ (variando concentração de biomassa e TDH) observou-se menor coeficiente de similaridade, de 70-72\%.

Em virtude da maior exposição da biomassa do separador de fases às condições avaliadas no ensaio, observou-se maior variação de coeficientes de similaridades nas amostras dessa biomassa. Apesar da maior variação do coeficiente de similaridade, foram observados maiores coeficientes de similaridade entre as amostras da biomassa do separador de fases dos reatores $\mathrm{R}_{35 \mathrm{D}}$, $\mathrm{R}_{6}$ e $\mathrm{R}_{\mathrm{BCS}}$ (Archaea: 69-86\%; Bacteria: 64-72\%). No ponto PA3 (antes do separador de fases) dos reatores $R_{35 \mathrm{D}}, \mathrm{R}_{6}$ e $\mathrm{R}_{\mathrm{BCS}}$ detectou-se ácido acético, em concentração entre 9 e $11 \mathrm{mg} / \mathrm{L}$, que foi consumido no separador de fases (não foi detectado ácido acético no efluente desses reatores). Provavelmente, o ácido acético atuou como fator de seleção na biomassa do separador de fases dos reatores $R_{35 D}, R_{6}$ e $R_{B C S}$, em virtude do maior coeficiente de similaridade referente ao domínio Archaea (69-86\%).

Quanto às morfologias observadas em exames microscópicos, verificou-se a presença de bacilos, filamentos, sarcinas e bacilos fluorescentes em todos os reatores (Figura 5.30). Sarcinas fluorescentes semelhantes à Methanosarcina $\mathrm{sp}$. foram observadas nos reatores $\mathrm{R}_{35 \mathrm{D}}$, $\mathrm{R}_{\mathrm{BCS}}, \mathrm{R}_{6}$ e $\mathrm{R}_{80}$; cistos nos reatores $\mathrm{R}_{35 \mathrm{~B}}, \mathrm{R}_{35 \mathrm{D}}$ e $\mathrm{R}_{\mathrm{BCS}}$; e espirilos nos reatores $\mathrm{R}_{6}$ e $\mathrm{R}_{80}$. 


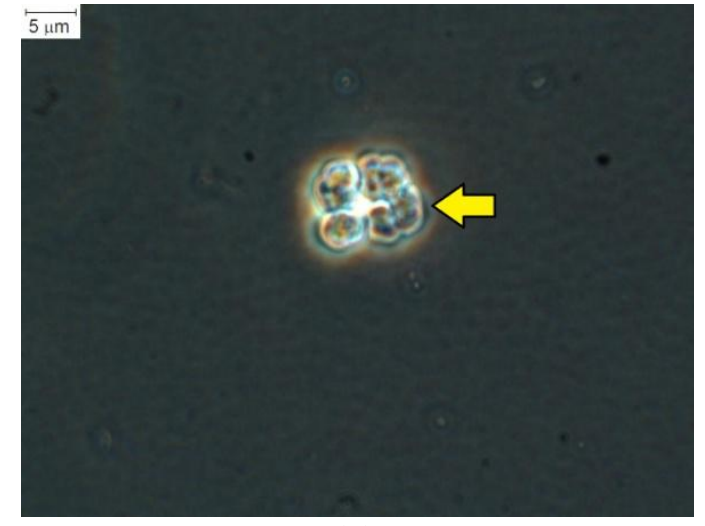

(a)

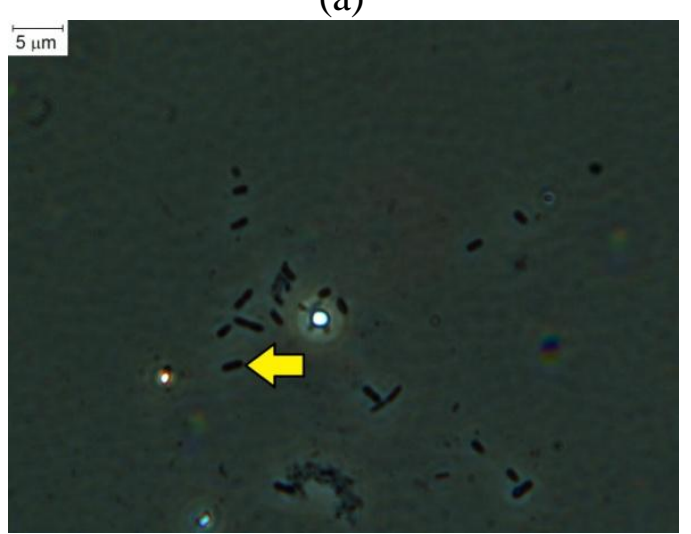

(c)

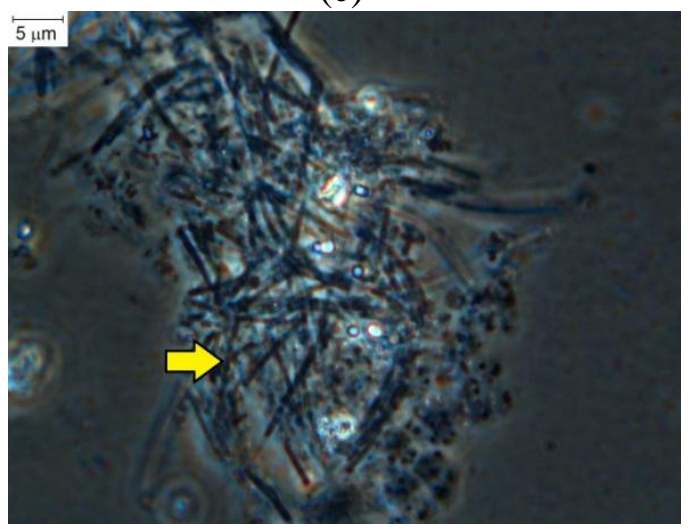

(e)

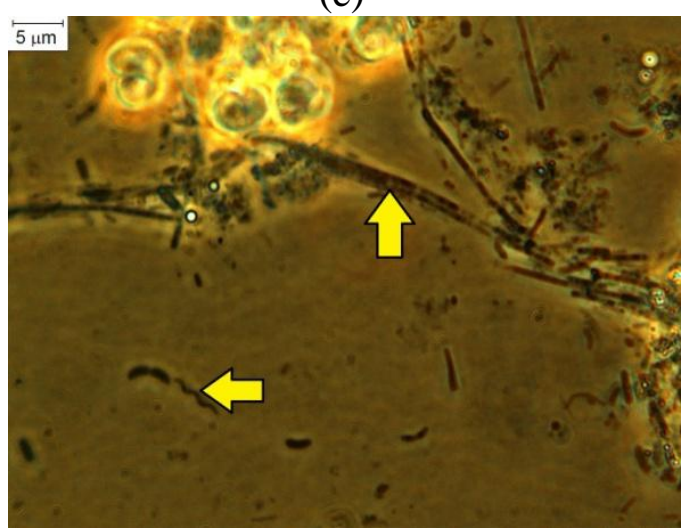

(g)

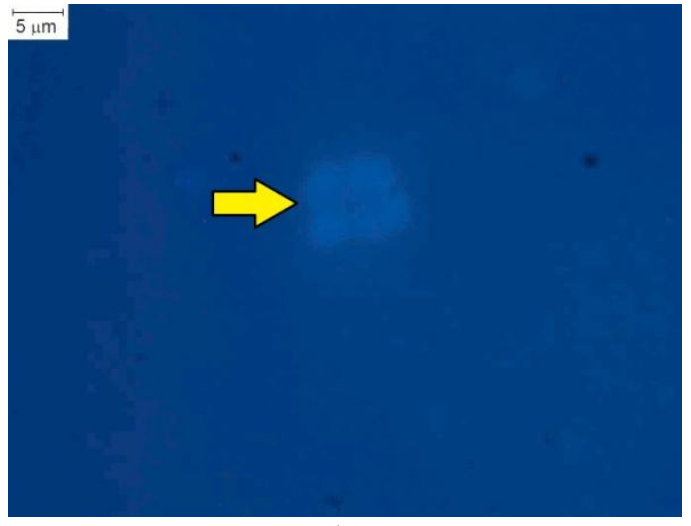

(b)

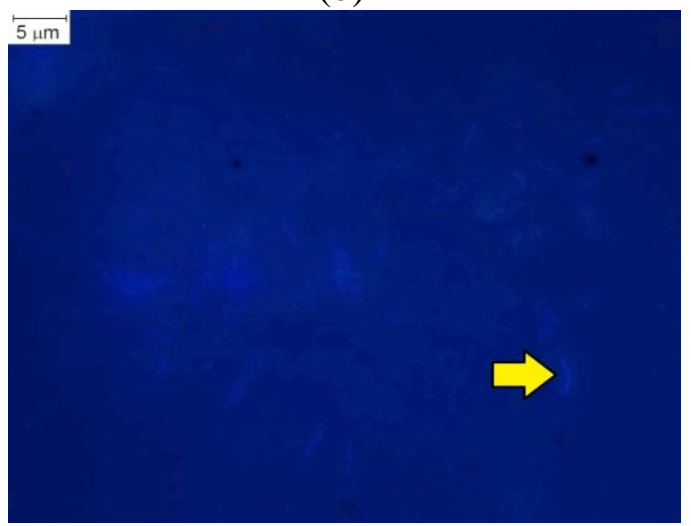

(d)

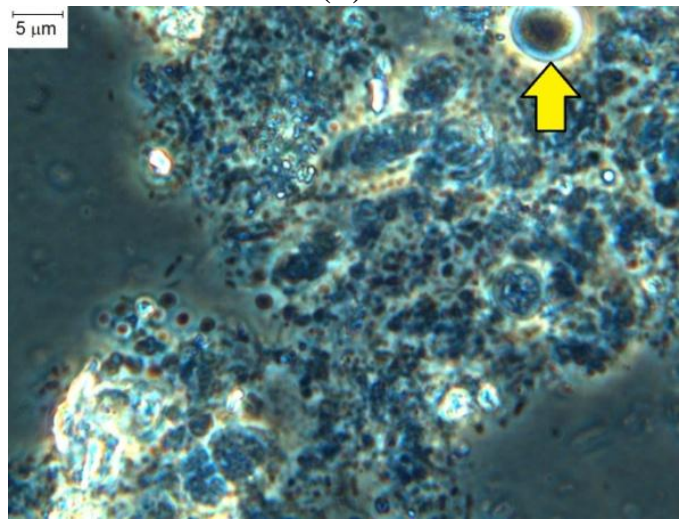

(f)

Figura 5.30: Morfologias observadas: sarcinas fluorescentes semelhantes à Methanosarcina sp. (contraste de fase - a - e fluorescência - b), bacilos (c), bacilos fluorescentes (d), arranjo semelhantes à Methanosaeta $\mathrm{sp}$. (e), cistos (f) filamentos e espirilos (g) 


\subsubsection{Considerações}

A comparação de parâmetros relacionados com a degradação de LAS, mediante matriz de correlação, evidenciou a maior influência da concentração de co-substratos, seguida pelo TDH e por último pela biodisponibilidade de LAS.

Verificou-se maior degradação de LAS em menor concentração de co-substratos, sendo observada degradação de 76\% em carga orgânica específica de 0,03 g DQO/g STV.d. O fornecimento de co-substratos em baixa concentração foi suficiente para manter a comunidade microbiana e favorecer a degradação de LAS.

A variação de TDH resultou em eficiências de degradação de LAS entre 18 e 55\%, para valores de TDH entre 6 e 80 h. Verificou-se o aumento da degradação de LAS com o aumento de TDH, todavia, esse aumento foi limitado pela redução da taxa de LAS aplicada, conforme observado em TDH de 80 h. Considerando a limitação da degradação de LAS em TDH de 80 h, ressaltou-se que o TDH de 35 h foi adequado para conciliar o tempo necessário para as reações de degradação do surfactante e a taxa de LAS aplicada.

Apesar da variação da biodisponibilidade de LAS, mediante concentração de biomassa (1,3-16 g ST/L), verificou-se variação de apenas $16 \%$ na degradação de LAS (entre 37 e $53 \%)$

Com relação à adsorção de LAS, verificou-se menor tempo para equilíbrio entre adsorção e degradação de LAS em duas situações: com o decréscimo da concentração de biomassa e pela redução de TDH (aumento da taxa de LAS aplicada).

Por meio da análise da variação espacial de LAS verificou-se significativa remoção no separador de fases (20-53\%). Essa remoção foi correlacionada positivamente com as eficiências de degradação de LAS obtidas, ou seja, as maiores eficiências de degradação foram obtidas em reatores com maior remoção no separador de fases. Atribuiu-se a remoção 
de LAS no separador de fases à condição anaeróbia facultativa e ao fornecimento de cosubstratos em baixa concentração. Além disso, verificou-se correlação linear negativa entre a remoção de LAS e a concentração de ácidos orgânicos voláteis no separador de fases.

Com relação às comunidades microbianas dos reatores, verificou-se maior variação dos coeficientes de similaridade entre amostras da biomassa do separador de fases (Archaea: 29-86\%; Bacteria: 52-76\%). Nas amostras da manta de lodo, a estrutura de grânulo da manta de lodo protegeu as comunidades microbianas das variações de condições (biodisponibilidade de LAS, TDH e concentração de co-substratos) resultando em menor variação dos coeficientes de similaridade (Archaea: 70-90\%; Bacteria: 69-83\%). 


\subsection{Degradação de LAS em água residuária de lavanderia}

\subsubsection{Caracterização da água de lavanderia comercial}

$\mathrm{Na}$ água de lavanderia comercial verificou-se concentração de LAS entre 90 e $350 \mathrm{mg} / \mathrm{L}$, com média de $216 \pm 77 \mathrm{mg} / \mathrm{L}$ (Figura 5.31a). A variação da concentração de LAS observada no presente estudo foi menor que a relatada em estudos anteriores, entre 12 e 1.024 mg/L (SEO et al., 2001; BRAGA e VARESCHE, 2011). Atribuiu-se a menor variação de LAS obtida ao controle de dosagem dos produtos de limpeza usados na lavanderia comercial. Decidiu-se pela diluição da água residuária de lavanderia em virtude da alta concentração de LAS na água de lavanderia (acima de $90 \mathrm{mg} / \mathrm{L}$ ), capaz de inibir o processo anaeróbio (vide revisão bibliográfica, p. 8). Assim, a relação de diluição variou entre 1:8 e 1:50, sendo em média 1:20 (Figura 5.31b).

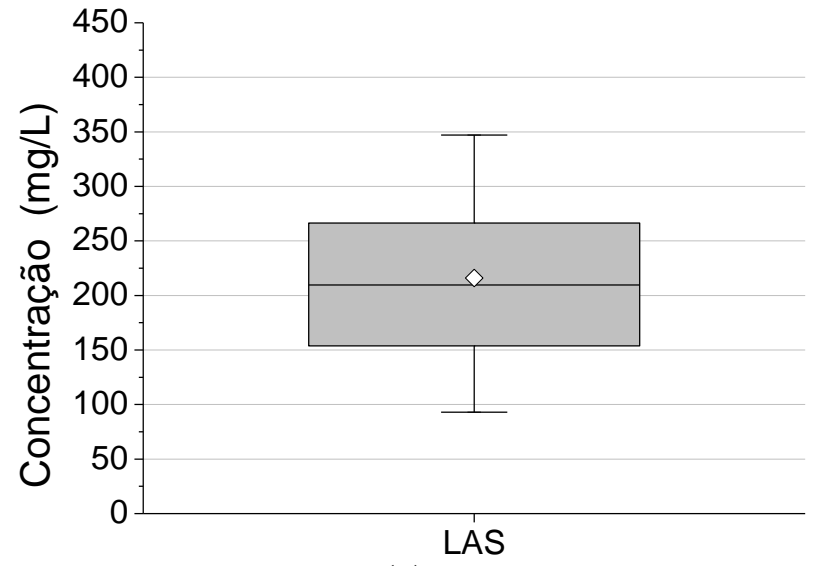

(a)

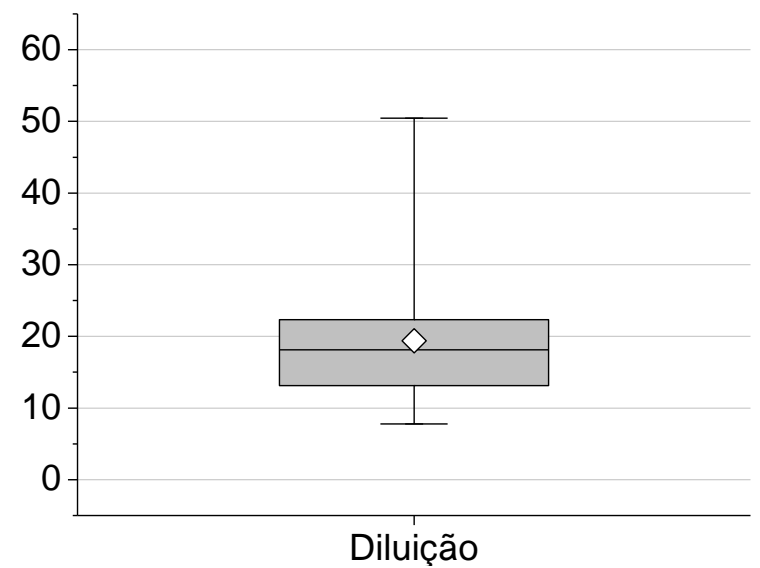

(b)

Figura 5.31: Box-plot de LAS (a) e diluição aplicada (b) em 16 amostras de água residuária de lavanderia 
Em relação à DQO verificou-se variação entre 900 e 5.200 mg/L para DQO bruta e entre 700 e $4.370 \mathrm{mg} / \mathrm{L}$ para DQO filtrada (Figura 5.32a). Estudos anteriores observaram 488 e 4.800 mg/L de DQO bruta (SEO et al., 2001; BRAGA e VARESCHE, 2011).

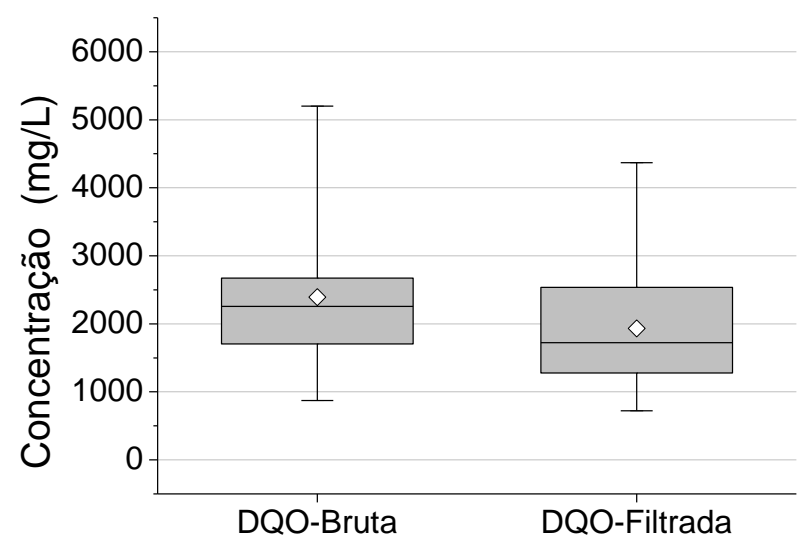

(a)

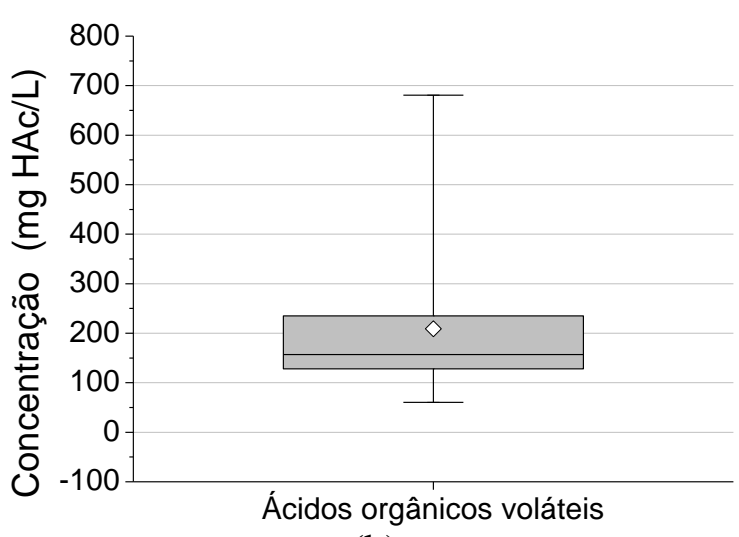

(b)

Figura 5.32: Box-plot de DQO bruta e filtrada (a), e ácidos orgânicos voláteis (b) em 16 amostras de água residuária de lavanderia

Observou-se concentração de ácidos orgânicos voláteis entre 60 e 680 mg HAc/L (Figura 5.32b). Foram detectados vários ácidos orgânicos voláteis (12), destacando-se ácido lático (média de 144ะ88 mg/L), além de significativa presença dos ácidos cítrico (0-120 $\mathrm{mg} / \mathrm{L})$, isovalérico (0-100 mg/L), málico (0-271 mg/L), butírico $(0-64 \mathrm{mg} / \mathrm{L})$ e propiônico (0$67 \mathrm{mg} / \mathrm{L}$ ) (Figura 5.33). Os demais ácidos foram detectados em concentração abaixo de $55 \mathrm{mg} / \mathrm{L}$. 


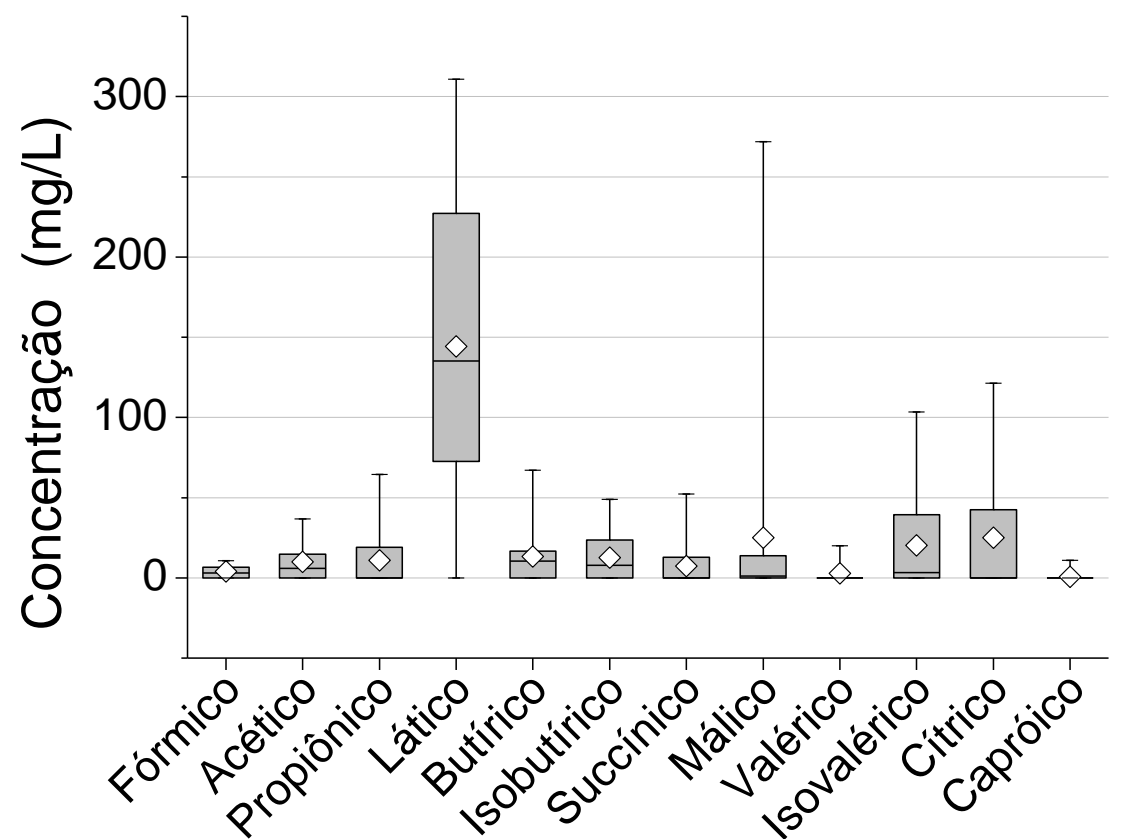

Figura 5.33: Box-plot de ácidos orgânicos voláteis detectados em 16 amostras de água residuária de lavanderia

Em relação aos sólidos totais (ST) e sólidos dissolvidos totais (SDT) verificou-se ampla variação, de 1,9 g a 6,6 g ST/L e de 1,5 a 6,1 g SDT/L, respectivamente, enquanto observou-se valor de sólidos suspensos totais (SST) entre 0,2 e 1,1 g SST/L (Figura 5.34). Os valores de SST foram próximos aos observados em estudos anteriores, entre 0,01 e 0,857 g SST/L (SEO et al., 2001; BRAGA e VARESCHE, 2011). Atribuiu-se os valores de SST à presença de fibras de roupas em virtude do seu desprendimento durante o processo de lavagem de roupas. 


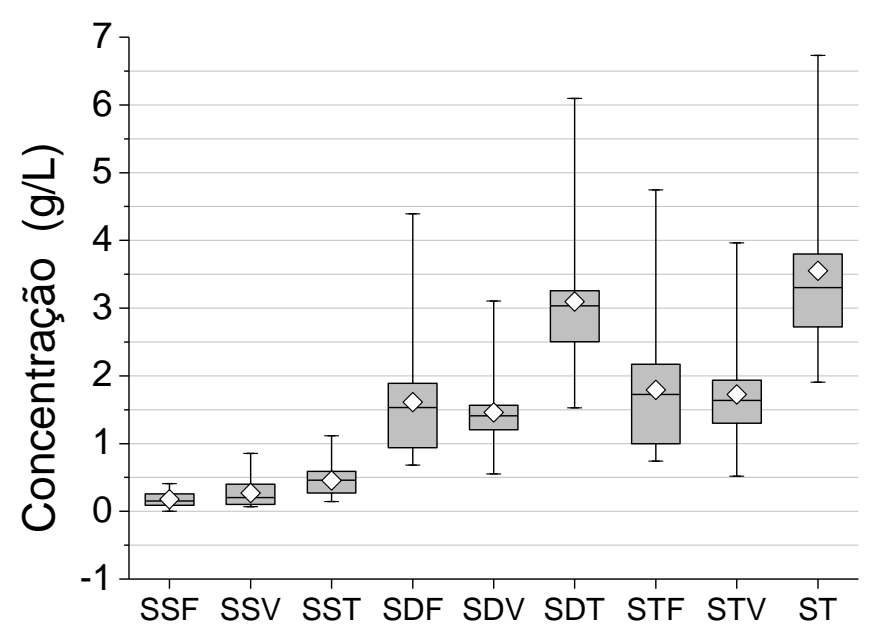

Figura 5.34: Box-plot de sólidos suspensos, dissolvidos e totais em 16 amostras de água residuária de lavanderia

Outro aspecto a ser destacado foi a presença de sais dissolvidos. Dentre os sólidos totais da água residuária de lavanderia, 44\% correspondiam aos sólidos dissolvidos fixos. Detectou-se fluoreto entre 0,02 e $74 \mathrm{mg} / \mathrm{L}$ (Figura 5.35a). Em relação ao fosfato, observou-se variação entre 0 e 13 mg P/L (Figura 5.35b). Em relação ao Nitrogênio Total Kjeldahl (NTK)

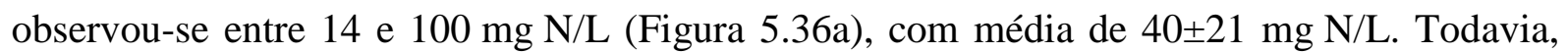
observou-se baixa concentração de nitrato, entre 0 e 2,3 mg N/L (Figura 5.36b). Observou-se grande variação de sulfato, entre 3 e $510 \mathrm{mg} \mathrm{S} / \mathrm{L}$ (Figura 5.37a), e sulfeto, entre 0,7 e $12,5 \mathrm{mg} \mathrm{S} / \mathrm{L}$ (Figura 5.37b).

Braga e Varesche (2011), observaram na água residuária de lavanderia maior valor de fosfato $(3,2-91 \mathrm{mg} \mathrm{P} / \mathrm{L})$; menor valor de sulfato $(0,5-34,2 \mathrm{mg} \mathrm{S} / \mathrm{L})$; e valores próximos de NTK (1-136 mg N/L; média: 32 \pm 26 mg N/L). As diferenças observadas nas concentrações de sulfato e fosfato entre o presente estudo e a caracterização realizada por Braga e Varesche (2011) foram atribuídas à diferença na composição de produtos usados nas lavanderias comerciais. 


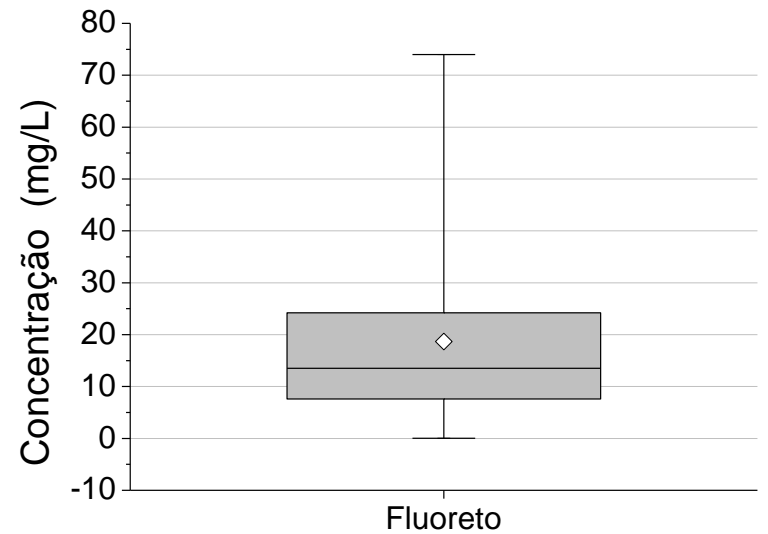

(a)

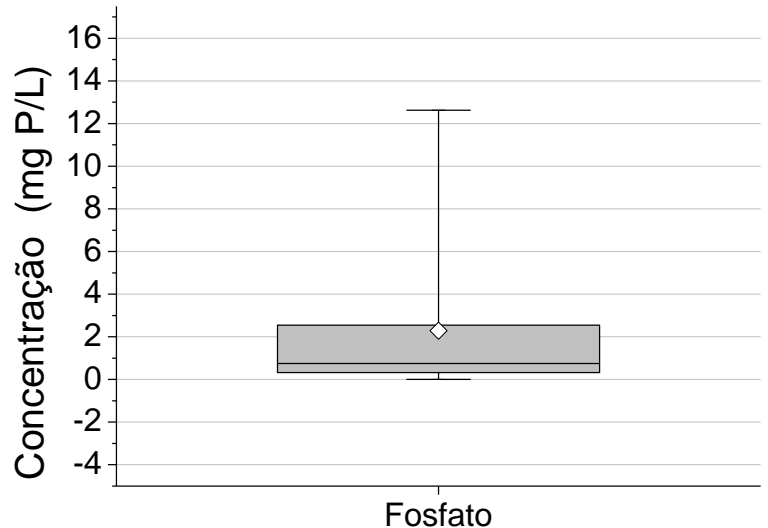

(b)

Figura 5.35: Box-plot de fluoreto (a) e fosfato (b) em 16 amostras de água residuária de lavanderia

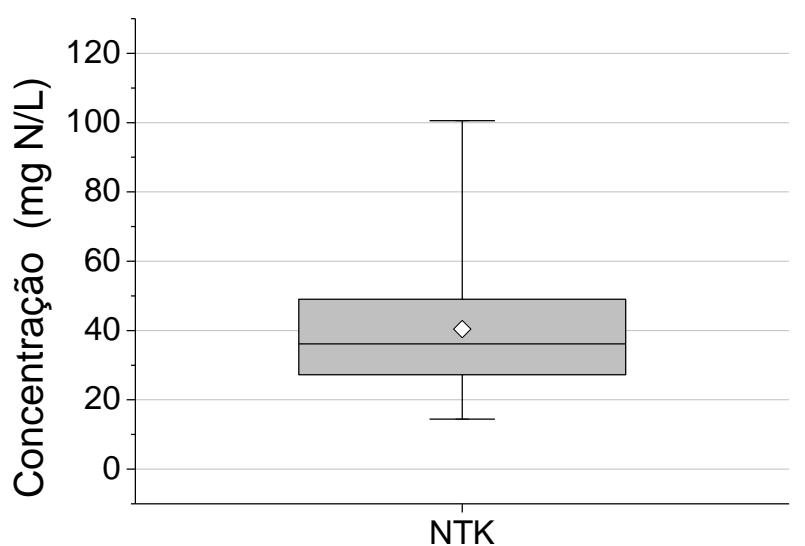

(a)

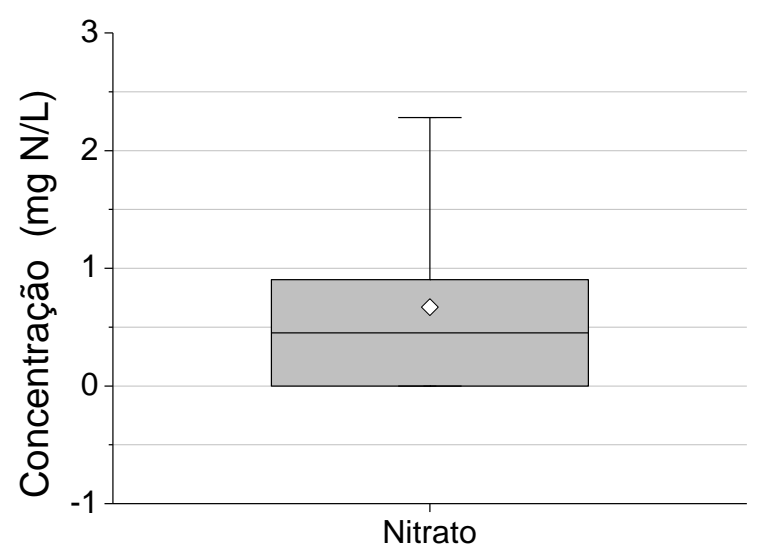

(b)

Figura 5.36: Box-plot de NTK (a) e nitrato (b) em 16 amostras de água residuária de lavanderia

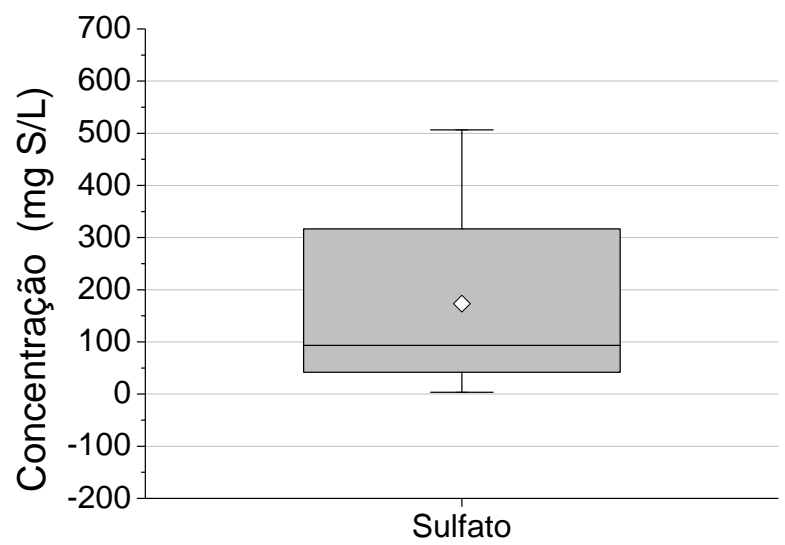

(a)

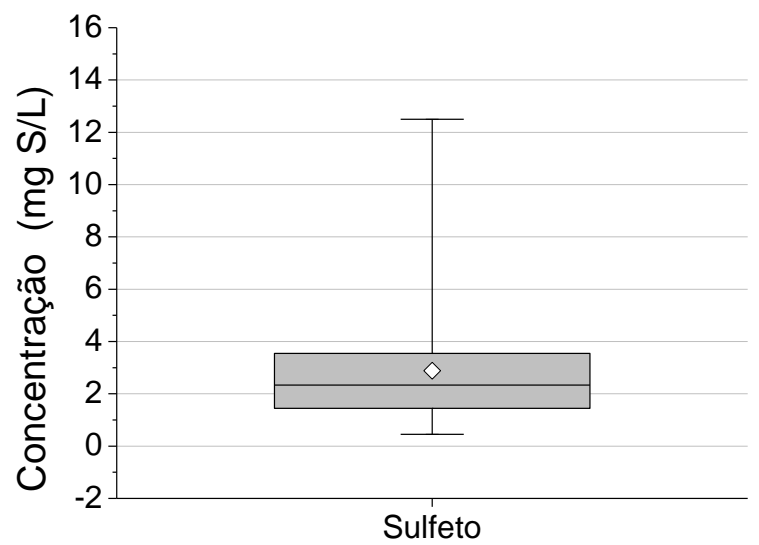

(b)

Figura 5.37: Box-plot de sulfato (a) e sulfeto (b) em 16 amostras de água residuária de lavanderia 
Em relação ao pH, verificou-se variação entre 8,7 e 12,2 (Figura 5.38a). Observou-se grande variação de alcalinidade parcial e total, entre 160 e $2.300 \mathrm{mg} \mathrm{CaCO}_{3} / \mathrm{L}$, e entre 200 e $2.500 \mathrm{mg} \mathrm{CaCO} / \mathrm{L}$, respectivamente (Figura 5.38b). A alcalinidade presente na água residuária de lavanderia foi provocada pelo hidróxido de sódio presente no detergente industrial usado na lavanderia (p. 20). Apesar da alta alcalinidade da água residuária de lavanderia (causada por hidróxido), foi necessária a adição de bicarbonato de sódio à alimentação do reator $\mathrm{R}_{\mathrm{L} 1}(400 \mathrm{mg} / \mathrm{L})$ para tamponar o meio. Em outro estudo de caracterização, observou-se pH ácido, entre 3,3 e 6,9, e, consequentemente, alcalinidade total menor, entre 0 e $82 \mathrm{mg} \mathrm{CaCO}_{3} / \mathrm{L}$ (BRAGA e VARESCHE, 2011). Essa diferença de pH atribuiu-se a diferença dos produtos usados nas lavanderias comerciais uma vez que há opção de detergentes alcalinos e ácidos para lavagem de roupas.

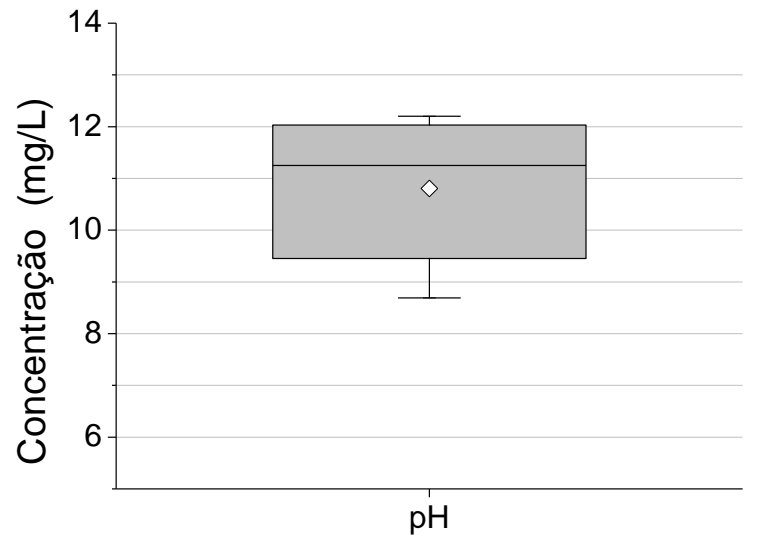

(a)

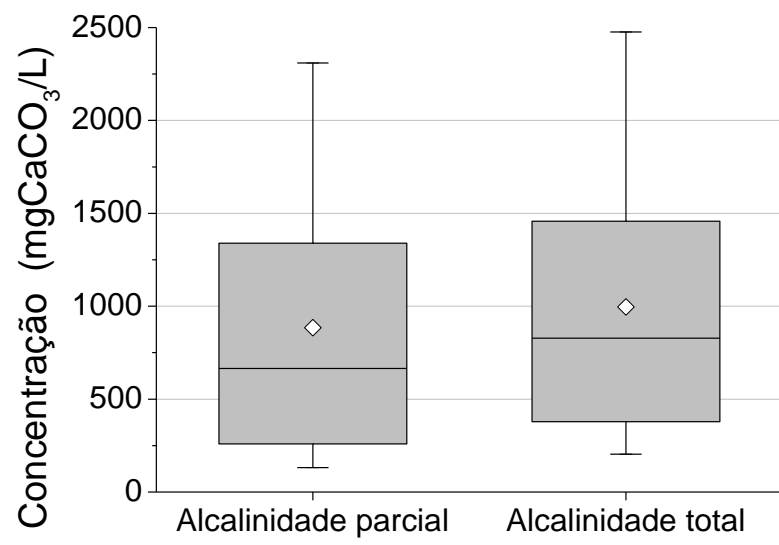

(b)

Figura 5.38: Box-plot de $\mathrm{pH}$ (a), alcalinidade parcial e total (b) em 16 amostras de água residuária de lavanderia

Observou-se na caracterização da água residuária de lavanderia que a variação de alguns parâmetros ( $\mathrm{pH}$, alcalinidade, sulfato e fosfato) depende da formulação dos produtos de limpeza usados. Com relação à carga orgânica e de nitrogênio, observou-se pouca diferença entre os valores de DQO e NTK do presente estudo e em caracterizações anteriores (supracitadas). Atribuiu-se a pouca diferença entre DQO e NTK dos estudos à similaridade de 
suas fontes, que constituíram, principalmente, de células mortas agregadas às roupas. Com relação às concentrações de LAS, um aspecto que reduziu consideravelmente a variação foi o controle da dosagem de produtos de limpeza, além do menor desperdício na lavanderia comercial.

\subsubsection{Caracterização da água de lavanderia em cada parte do ensaio}

Os dados de caracterização da água de lavanderia foram divididos em relação a cada parte do ensaio (Partes 1 e 2). Na Parte 1 foi avaliada a degradação de 10 mg/L de LAS em dois reatores, um alimentado com água residuária de lavanderia e outro com água residuária sintética. Na Parte 2 foi avaliada a degradação de 10-20 mg/L de LAS em reator com água de lavanderia, e de $10 \mathrm{mg} / \mathrm{L}$ de LAS em reator com água residuária sintética com menor concentração de cloreto de amônio (20 mg/L). Na parte 2, esses dados foram separados entre os referentes à Etapa 2.1, Etapa 2.2 e os dados da água residuária usada no $52^{\circ}$ dia (início da Etapa 2.2). Os dados da água residuária usada no $52^{\circ}$ dia de operação da Parte 2 foram analisados individualmente, em virtude das altas concentrações de DQO e LAS (5.200 mg/L e $320 \mathrm{mg} / \mathrm{L}$, respectivamente).

Observou-se que a média de concentração de LAS foi maior na Parte $1(271 \pm 52 \mathrm{mg} / \mathrm{L})$ que na Parte 2 (138-171 mg/L) (Tabela 5.10). Também se observou maior média de DQO e NTK na Parte 1, 2.572 $\pm 916 \mathrm{mg} / \mathrm{L}$ e $44 \pm 18 \mathrm{mg}$ N/L, respectivamente. Em virtude da maior média de LAS, aplicou-se diluição em menor proporção na Parte 1 (1:25).

Com relação aos sólidos totais, observou-se pequena variação, entre 2,7 e 4,0 g ST/L, nas Partes 1 e 2 (Tabela 5.10). Essa variação foi menor entre os sólidos suspensos, cujas médias das Partes 1 e 2 variaram entre 0,3 e $0,4 \mathrm{~g} \mathrm{SST/L}$. 
Na Parte 1 e na Etapa 2.1, verificou-se maior média de alcalinidade total (989$\left.1329 \mathrm{mg} \mathrm{CaCO}_{3} / \mathrm{L}\right)$ e pH (11,2-11,6) (Tabela 5.10). A redução das médias de alcalinidade (para 354 mg $\mathrm{CaCO}_{3} / \mathrm{L}$ ) e pH (para 9,4) na Etapa 2.2 foram atribuídas à adição de acidulante neutralizante na lavanderia comercial (além dos detergentes utilizados; item 4.3, p. 20). A adição do acidulante neutralizante também provocou aumento significativo da concentração média de sulfato na Etapa 2.2, para $280 \pm 110 \mathrm{mg} \mathrm{S} / \mathrm{L}$, em virtude da presença de sulfato de sódio na composição do acidulante neutralizante (item 4.3, p. 20).

Tabela 5.10: Caracterização da água residuária de lavanderia

\begin{tabular}{|c|c|c|c|c|}
\hline \multirow[t]{2}{*}{ Parâmetro } & \multirow[t]{2}{*}{ Parte 1} & \multicolumn{3}{|c|}{ Parte 2} \\
\hline & & Etapa 2.1 & $52^{\circ}$ dia & Etapa 2.2 \\
\hline Diluição & $25 \pm 9$ & $18 \pm 2$ & 24 & $10 \pm 1$ \\
\hline LAS (mg/L) & $271 \pm 52$ & $171 \pm 20$ & $320 \pm 20$ & $138 \pm 47$ \\
\hline \multicolumn{5}{|l|}{ DQO (mg/L) } \\
\hline Bruta & $2572 \pm 916$ & $2093 \pm 451$ & $5200 \pm 60$ & $1678 \pm 140$ \\
\hline Filtrada & $2179 \pm 796$ & $1591 \pm 358$ & $4370 \pm 30$ & $1299 \pm 108$ \\
\hline Ácidos orgânicos voláteis (mg HAc/L) & $207 \pm 100$ & $151 \pm 72$ & $680 \pm 70$ & $153 \pm 58$ \\
\hline \multicolumn{5}{|l|}{ Alcalinidade $\left(\mathrm{mg} \mathrm{CaCO}_{3} / \mathrm{L}\right)$} \\
\hline Parcial & $1269 \pm 649$ & $883 \pm 964$ & $713 \pm 100$ & $254 \pm 97$ \\
\hline Total & $1329 \pm 680$ & $989 \pm 1001$ & $978 \pm 100$ & $354 \pm 103$ \\
\hline $\mathrm{pH}$ & $11,6 \pm 0,9$ & $11,2 \pm 1,3$ & $9,5 \pm 0,1$ & $9,4 \pm 0,9$ \\
\hline Fluoreto $(\mathrm{mg} / \mathrm{L})$ & $14 \pm 11$ & $13 \pm 8$ & $74 \pm 5$ & $17 \pm 16$ \\
\hline Fosfato (mg P/L) & $1,2 \pm 2,5$ & $4 \pm 6$ & $5 \pm 5$ & $2 \pm 1$ \\
\hline NTK (mg N/L) & $44 \pm 18$ & $30 \pm 5$ & $100 \pm 10$ & $31 \pm 7$ \\
\hline Nitrato (mg N/L) & $0,4 \pm 0,3$ & $0,8 \pm 0,8$ & $2 \pm 5$ & $2 \pm 1$ \\
\hline Sulfato (mg S/L) & $128 \pm 181$ & $115 \pm 150$ & $300 \pm 10$ & $280 \pm 110$ \\
\hline Sulfeto (mg S/L) & $1,7 \pm 1,1$ & $3 \pm 1$ & $13 \pm 1$ & $2,1 \pm 0,7$ \\
\hline \multicolumn{5}{|l|}{ Sólidos } \\
\hline $\operatorname{SST}(\mathrm{g} / \mathrm{L})$ & $0,4 \pm 0,2$ & $0,4 \pm 0,2$ & $1,1 \pm 0,1$ & $0,3 \pm 0,1$ \\
\hline $\mathrm{SSV}(\mathrm{g} / \mathrm{L})$ & $0,2 \pm 0,2$ & $0,3 \pm 0,2$ & $0,9 \pm 0,1$ & $0,2 \pm 0,1$ \\
\hline $\mathrm{SSF}(\mathrm{g} / \mathrm{L})$ & $0,2 \pm 0,1$ & $0,1 \pm 0,1$ & $0,3 \pm 0,1$ & $0,1 \pm 0,1$ \\
\hline SDT (g/L) & $3,6 \pm 1,3$ & $2,4 \pm 0,6$ & $5,6 \pm 0,7$ & $2,4 \pm 0,6$ \\
\hline $\mathrm{SDV}(\mathrm{g} / \mathrm{L})$ & $1,4 \pm 0,5$ & $1,4 \pm 0,1$ & $3,1 \pm 0,7$ & $1,2 \pm 0,3$ \\
\hline $\mathrm{SDF}(\mathrm{g} / \mathrm{L})$ & $2,2 \pm 1,3$ & $1,0 \pm 0,5$ & $2,5 \pm 0,7$ & $1,2 \pm 0,4$ \\
\hline ST (g/L) & $4,0 \pm 1,4$ & $2,9 \pm 0,7$ & $6,7 \pm 0,7$ & $2,7 \pm 0,6$ \\
\hline $\operatorname{STV}(\mathrm{g} / \mathrm{L})$ & $1,6 \pm 0,6$ & $1,7 \pm 0,3$ & $4,0 \pm 0,7$ & $1,4 \pm 0,2$ \\
\hline STF $(g / L)$ & $2,4 \pm 1,3$ & $1,2 \pm 0,7$ & $2,8 \pm 0,7$ & $1,3 \pm 0,5$ \\
\hline
\end{tabular}


Com relação a sulfeto e fluoreto, observou-se pouca variação das médias, entre 1,7 e 3,1 mg S/L, e entre 13 e $17 \mathrm{mg} / \mathrm{L}$, respectivamente (Tabela 5.10). A maior concentração média de nitrato foi na Etapa $2.2(2 \pm 5 \mathrm{mg} \mathrm{N} / \mathrm{L})$. Por sua vez, a maior concentração de fosfato foi na Etapa $2.1(4 \pm 6 \mathrm{mg} \mathrm{P} / \mathrm{L})$.

Com relação aos ácidos orgânicos voláteis, observou-se média pouco maior na Parte 1, 207£100 mg HAc/L, enquanto na Parte 2 observou-se média entre 151 e 170 mg HAc/L (Tabela 5.10). Detectou-se presença significativa dos seguintes ácidos: lático (124-311 mg/L), málico (5-272 mg/L), propiônico (3-64 mg/L), butírico (6-67 mg/L), isobutírico (2-49 mg/L), isovalérico (10-43 mg/L) e cítrico (17-48 mg/L) (Tabela 5.11).

Tabela 5.11: Ácidos orgânicos voláteis detectados na água residuária de lavanderia

\begin{tabular}{lcccc}
\hline Ácidos (mg/L) & Parte 1 & \multicolumn{3}{c}{ Parte 2 } \\
& & Etapa 2.1 & $52^{\circ}$ dia & Etapa 2.2 \\
\hline Fórmico & $6 \pm 3$ & $1 \pm 1$ & $10 \pm 5$ & $3 \pm 5$ \\
Acético & $8 \pm 11$ & $5 \pm 6$ & $7 \pm 5$ & $18 \pm 19$ \\
Propiônico & $14 \pm 16$ & $3 \pm 6$ & $64 \pm 5$ & $\mathrm{ND}$ \\
Lático & $124 \pm 92$ & $145 \pm 68$ & $311 \pm 5$ & $137 \pm 84$ \\
Butírico & $6 \pm 8$ & $8 \pm 5$ & $67 \pm 5$ & $18 \pm 13$ \\
Isobutírico & $18 \pm 14$ & $2 \pm 4$ & $49 \pm 5$ & $4 \pm 4$ \\
Succínico & $2 \pm 6$ & $7 \pm 9$ & $\mathrm{ND}$ & $19 \pm 24$ \\
Málico & $10 \pm 24$ & $5 \pm 11$ & $272 \pm 5$ & $9 \pm 7$ \\
Valérico & $6 \pm 8$ & $\mathrm{ND}$ & $\mathrm{ND}$ & $\mathrm{ND}$ \\
Isovalérico & $28 \pm 39$ & $10 \pm 17$ & $43 \pm 5$ & $13 \pm 23$ \\
Cítrico & $48 \pm 49$ & $17 \pm 33$ & $\mathrm{ND}$ & $\mathrm{ND}$ \\
Capróico & $2 \pm 4$ & $\mathrm{ND}$ & $\mathrm{ND}$ & $\mathrm{ND}$ \\
\hline
\end{tabular}

$\mathrm{Na}$ água residuária de lavanderia no $52^{\circ}$ dia de operação da Parte 2 , foram observadas as maiores concentrações de matéria orgânica, nitrogênio e sólidos (Tabela 5.10). A concentração de DQO bruta foi de $5.200 \mathrm{mg} / \mathrm{L}$; a de NTK foi de $100 \mathrm{mg} \mathrm{N} / \mathrm{L}$; e a de sólidos totais, dissolvidos e suspensos foi de 6,7 g ST/L, 5,6 g SDT/L e 1,1 g SST/L, respectivamente. Além disso, observou-se alta concentração de LAS (320 mg/L) e a maior concentração de ácidos orgânicos voláteis (680 mg HAc/L). Dentre os ácidos orgânicos 
voláteis detectados na água residuária de lavanderia do $52^{\circ}$ dia, destacou-se ácido lático (311 mg/L) e ácido málico (272 mg/L) (Tabela 5.11).

\subsubsection{Monitoramento - Parte 1}

Durante a operação dos reatores $\mathrm{R}_{\mathrm{L} 1}$ (água residuária de lavanderia diluída) e $\mathrm{R}_{\mathrm{S} 1}$ (água residuária sintética acrescida de LAS padrão) observou-se que alguns valores dos parâmetros foram próximos. A concentração média de ácidos orgânicos voláteis foi de 25 $21 \mathrm{mg} \mathrm{HAc/L}$, em ambos os reatores (Tabela 5.12). Observou-se concentração média de SST de $13 \pm 12 \mathrm{mg} / \mathrm{L}$ no reator $\mathrm{R}_{\mathrm{L} 1}$, e $17 \pm 14 \mathrm{mg} / \mathrm{L}$ no reator $\mathrm{R}_{\mathrm{S} 1}$. Ressalta-se que a concentração de SST no reator $\mathrm{R}_{\mathrm{L} 1}$ foi baixa $(14 \mathrm{mg} / \mathrm{L})$ devido à diluição da água residuária de lavanderia. Em virtude das concentrações de SST, observou-se pequena diferença entre o total de SST descartado no efluente (491 mg no reator $\mathrm{R}_{\mathrm{L} 1}$ e $586 \mathrm{mg}$ no reator $\mathrm{R}_{\mathrm{S} 1}$ ). 
Tabela 5.12: Parâmetros analisados na Parte 1

\begin{tabular}{|c|c|c|}
\hline Parâmetro & $\mathrm{R}_{\mathrm{L} 1}$ & $\mathrm{R}_{\mathrm{S} 1}$ \\
\hline \multicolumn{3}{|l|}{ Ácidos orgânicos voláteis (mg HAc/L) } \\
\hline Efluente & $25 \pm 14$ & $25 \pm 21$ \\
\hline \multicolumn{3}{|l|}{ Alcalinidade $\left(\mathrm{mg} \mathrm{CaCO}_{3} / \mathrm{L}\right)$} \\
\hline \multicolumn{3}{|l|}{ Afluente } \\
\hline Parcial & $206 \pm 57$ & $451 \pm 78$ \\
\hline Total & $269 \pm 72$ & $564 \pm 100$ \\
\hline \multicolumn{3}{|l|}{ Efluente } \\
\hline Parcial & $220 \pm 77$ & $148 \pm 70$ \\
\hline Total & $295 \pm 93$ & $197 \pm 87$ \\
\hline \multicolumn{3}{|l|}{ Biomassa no reator $(\mathrm{g} / \mathrm{L})$} \\
\hline ST & $0,58 \pm 0,12$ & $1,56 \pm 0,13$ \\
\hline STV & $0,45 \pm 0,09$ & $0,50 \pm 0,09$ \\
\hline STF & $0,13 \pm 0,05$ & $1,05 \pm 0,07$ \\
\hline \multicolumn{3}{|l|}{ DQO bruta } \\
\hline Afluente (mg/L) & $131 \pm 45$ & $93 \pm 25$ \\
\hline Efluente (mg/L) & $55 \pm 27$ & $62 \pm 33$ \\
\hline Remoção (\%) & $59 \pm 14$ & $33 \pm 22$ \\
\hline Taxa de carregamento orgânico (kg DQO/m³.d) & $0,09 \pm 0,04$ & $0,06 \pm 0,02$ \\
\hline Carga orgânica específica (g DQO/g STV.d) & $0,20 \pm 0,09$ & $0,12 \pm 0,04$ \\
\hline \multicolumn{3}{|l|}{ LAS } \\
\hline Afluente (mg/L) & $11 \pm 3$ & $10 \pm 3$ \\
\hline Efluente $(\mathrm{mg} / \mathrm{L})$ & $2 \pm 1$ & $4 \pm 2$ \\
\hline \multicolumn{3}{|l|}{$\mathrm{pH}$} \\
\hline Afluente & $8,7 \pm 0,5$ & $8,0 \pm 0,1$ \\
\hline Efluente, & $8,2 \pm 0,5$ & $7,1 \pm 0,2$ \\
\hline \multicolumn{3}{|l|}{ SST } \\
\hline Efluente (mg/L) & $13 \pm 12$ & $17 \pm 14$ \\
\hline Total descartado no efluente (mg) & 491 & 586 \\
\hline \multicolumn{3}{|l|}{ Sulfato (mg S/L) } \\
\hline Afluente & $6 \pm 8$ & $0,05 \pm 0,13$ \\
\hline Efluente & $4 \pm 7$ & $0,5 \pm 0,4$ \\
\hline \multicolumn{3}{|l|}{ Sulfeto (mg S/L) } \\
\hline Afluente & $0,2 \pm 0,1$ & $0,15 \pm 0,07$ \\
\hline Efluente & $0,4 \pm 0,9$ & $0,14 \pm 0,09$ \\
\hline
\end{tabular}

Observou-se $\mathrm{pH}$ maior no reator $\mathrm{R}_{\mathrm{L} 1}$ (8,2-8,7; Tabela 5.12), em virtude do alcalinizante empregado no detergente de uso profissional (hidróxido de sódio, p. 20). No reator $\mathrm{R}_{\mathrm{L} 1}$, observou-se pequeno aumento da alcalinidade total, de $269 \mathrm{mg} \mathrm{CaCO} / \mathrm{L}$ no afluente, para $295 \mathrm{mg} \mathrm{CaCO}_{3} / \mathrm{L}$ no efluente. Todavia, verificou-se maior consumo de alcalinidade no reator $\mathrm{R}_{\mathrm{S} 1}$ (redução de 564 para $200 \mathrm{mg} \mathrm{CaCO}_{3} / \mathrm{L}$ da alcalinidade total). 
Em virtude da concentração de DQO afluente, entre 93 e $131 \mathrm{mg} / \mathrm{L}$, obteve-se baixa remoção de DQO bruta $(<60 \%)$, em ambos os reatores (Tabela 5.12). A carga orgânica específica do reator $\mathrm{R}_{\mathrm{L} 1}\left(0,20 \mathrm{~g}\right.$ DQO/g STV.d) foi maior que a do $\mathrm{R}_{\mathrm{S} 1}(0,12 \mathrm{~g}$ DQO/g STV.d) em virtude da diluição aplicada na água de lavanderia para obter concentração de LAS similar nos dois reatores (em torno de $10 \mathrm{mg} / \mathrm{L}$ ).

Verificou-se maior concentração de sulfato no reator alimentado com água residuária de lavanderia $\left(\mathrm{R}_{\mathrm{L} 1}\right.$ : 4-6 mg $\left.\mathrm{S} / \mathrm{L}\right)$ que no reator com água residuária sintética $\left(\mathrm{R}_{\mathrm{S} 1}: 0,05\right.$ 0,5mg S/L) (Tabela 5.12). Em relação ao sulfeto verificou-se menor variação em ambos os reatores, cujos valores foram entre 0,1 e $0,4 \mathrm{mg} \mathrm{S} / \mathrm{L}$.

Apesar das médias similares do total de ácidos orgânicos voláteis no efluente dos dois reatores (25 mg HAc/L; Tabela 5.12), observou-se diferenças nos ácidos detectados. No reator $\mathrm{R}_{\mathrm{L} 1}$ foram detectados 12 ácidos orgânicos voláteis, destacando-se o ácido isobutírico

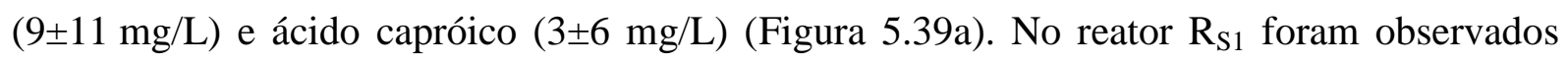
seis ácidos: propiônico, butírico, isobutírico, valérico, isovalérico e capróico (Figura 5.39b). Nos dois reatores, destacou-se a presença de ácido isobutírico (9 mg/L) e ácido capróico (3$7 \mathrm{mg} / \mathrm{L})$. A persistência de ácido isobutírico na presença de LAS já foi observada anteriormente no presente estudo (item 5.3, p. 70) e em outros estudos com LAS (JIANG et al., 2007; ZHANG et al., 2009). 


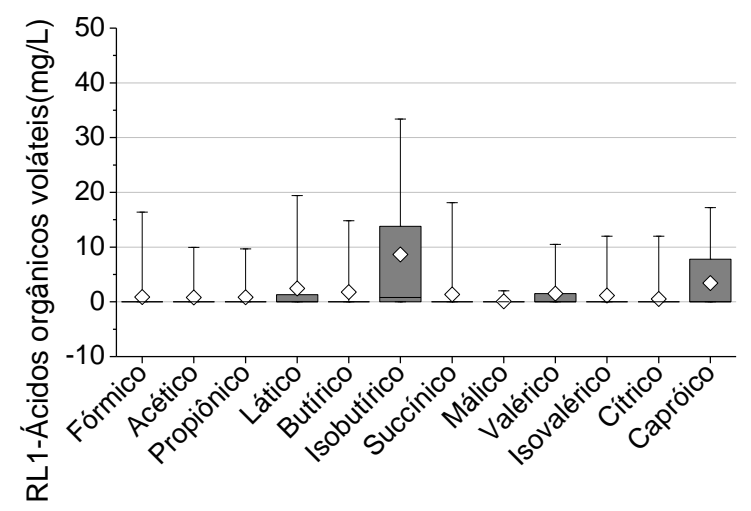

(a)

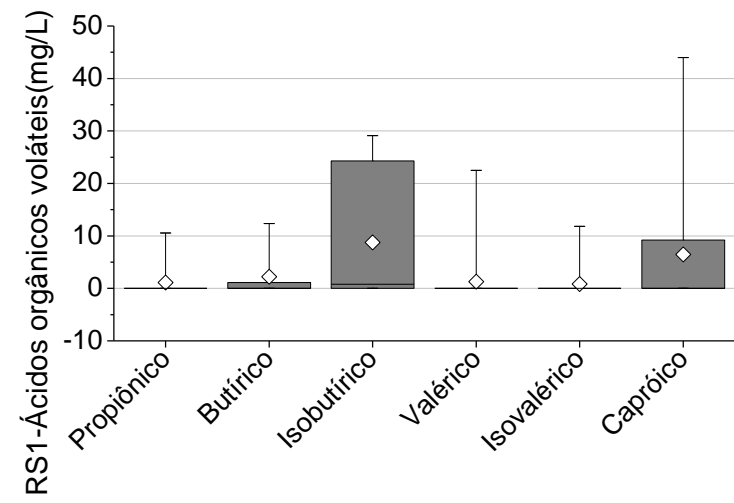

(b)

Figura 5.39: Box-plot de ácidos orgânicos voláteis em 23 amostras de efluente dos reatores $\mathrm{R}_{\mathrm{L} 1}$ (a) e $\mathrm{R}_{\mathrm{S} 1}$ (b)

Em relação à concentração da biomassa do reator observou-se pouca discrepância entre os reatores, sendo observado aumento de 0,08 g STV para 0,29-0,33 g STV (Tabela 5.13). Ao final do experimento, observou-se que cerca de 50\% dos sólidos voláteis encontravam-se na manta de lodo e o restante na região do separador de fases (Figura 5.40).

Tabela 5.13: Sólidos dos reatores $\mathrm{R}_{\mathrm{L} 1}$ e $\mathrm{R}_{\mathrm{S} 1}$, no início e fim do ensaio

\begin{tabular}{lcc}
\hline Sólidos & $\mathrm{R}_{\mathrm{L} 1}$ & $\mathrm{R}_{\mathrm{S} 1}$ \\
\hline Inicial - Manta de lodo & & \\
ST (g) & $0,09 \pm 0,03$ & $0,09 \pm 0,03$ \\
STV (g) & $0,08 \pm 0,03$ & $0,08 \pm 0,03$ \\
STF (g) & $0,01 \pm 0,01$ & $0,01 \pm 0,01$ \\
Final & & \\
Manta de lodo & \\
ST (g) & $0,15 \pm 0,05$ & $0,61 \pm 0,10$ \\
STV (g) & $0,14 \pm 0,05$ & $0,18 \pm 0,07$ \\
STF (g) & $0,01 \pm 0,01$ & $0,43 \pm 0,08$ \\
Separador de fases & & \\
ST (g) & $0,23 \pm 0,06$ & $0,40 \pm 0,08$ \\
STV (g) & $0,15 \pm 0,05$ & $0,15 \pm 0,06$ \\
STF (g) & $0,07 \pm 0,02$ & $0,25 \pm 0,07$ \\
Total & & \\
ST (g) & $0,38 \pm 0,06$ & $1,01 \pm 0,10$ \\
STV (g) & $0,29 \pm 0,05$ & $0,33 \pm 0,07$ \\
STF (g) & $0,09 \pm 0,03$ & $0,69 \pm 0,08$ \\
\hline
\end{tabular}




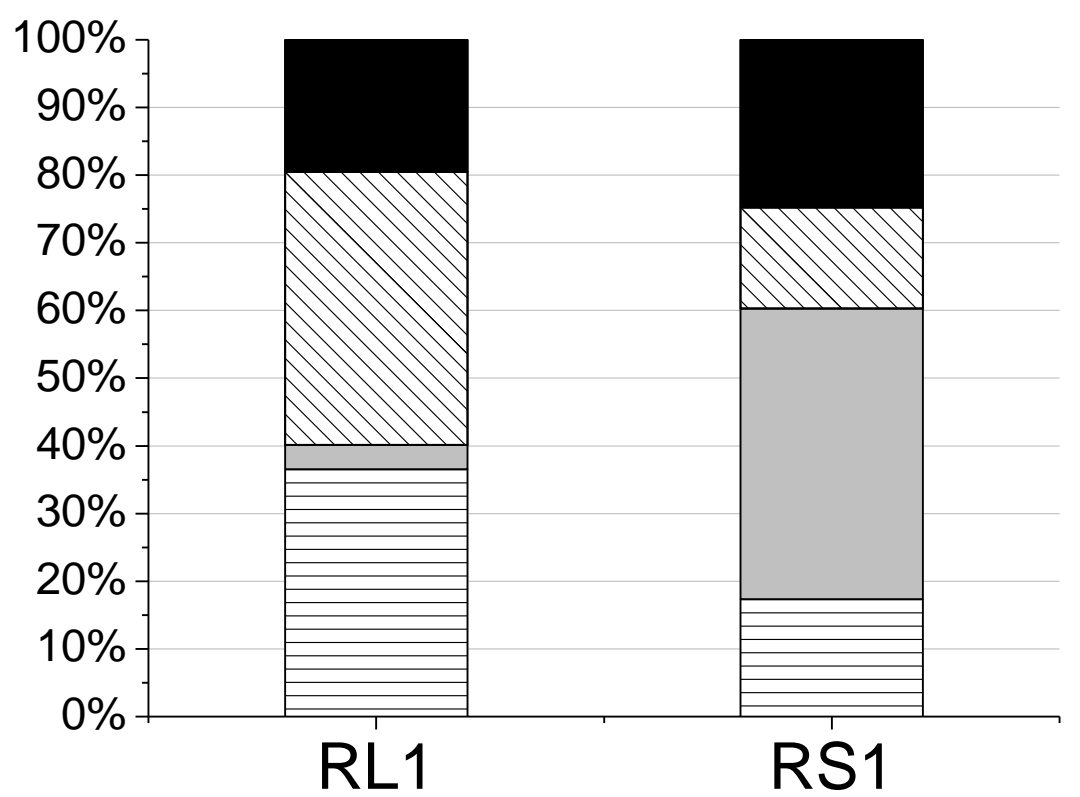

Figura 5.40: Distribuição de sólidos ao final da Parte 1: STV (目) e STF ( $\square$ ) na manta de lodo, e STV $(\mathbb{Q})$ e $\operatorname{STF}(\square)$ no separador de fases

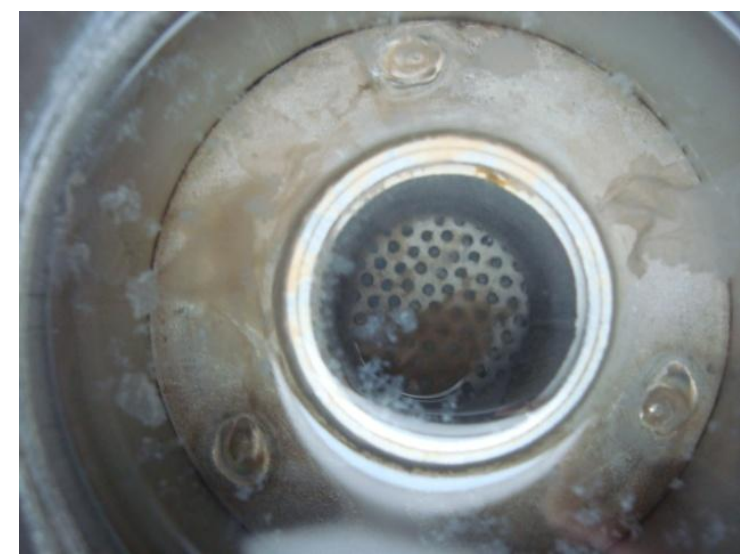

(a)

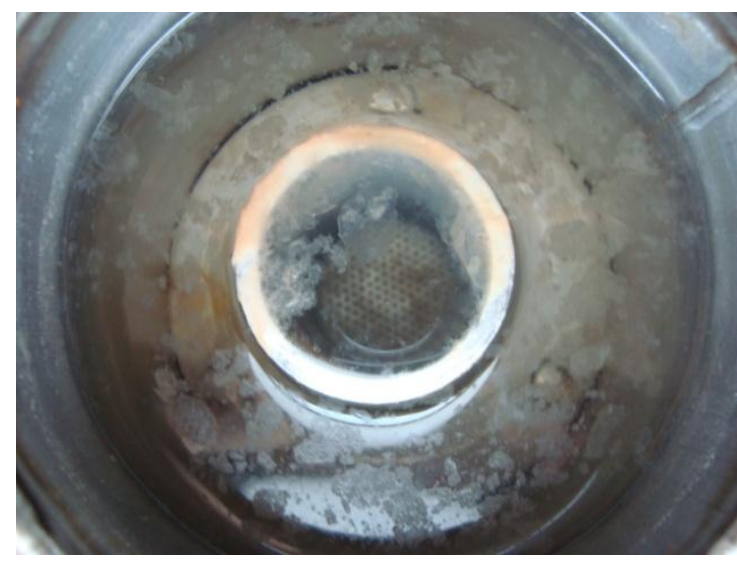

(b)

Figura 5.41: Biomassa na região do separador de fases aos 13 dias de operação nos reatores $\mathrm{R}_{\mathrm{L} 1}$ (a) e $\mathrm{R}_{\mathrm{S} 1}$ (b)

Verificou-se a condição anaeróbia estrita na manta de lodo, devido à ausência de coloração nessa região após adição de resazurina à alimentação (Figura 5.42a). Na região do separador de fases, verificou-se coloração rosa indicativa de condição anaeróbia facultativa. Observou-se essa mesma coloração no tubo de saída do separador de fases (Figura 5.42a) e nos frascos coletores de efluente (Figura 5.42b). 


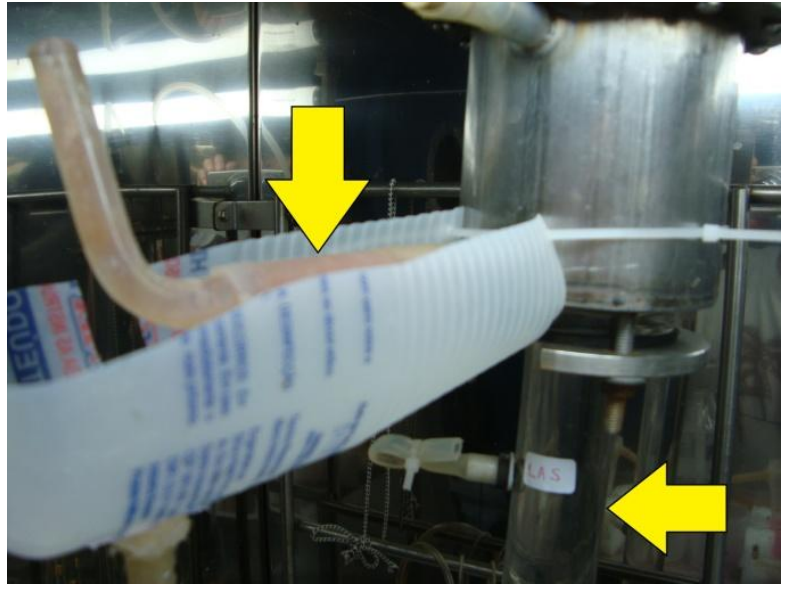

(a)

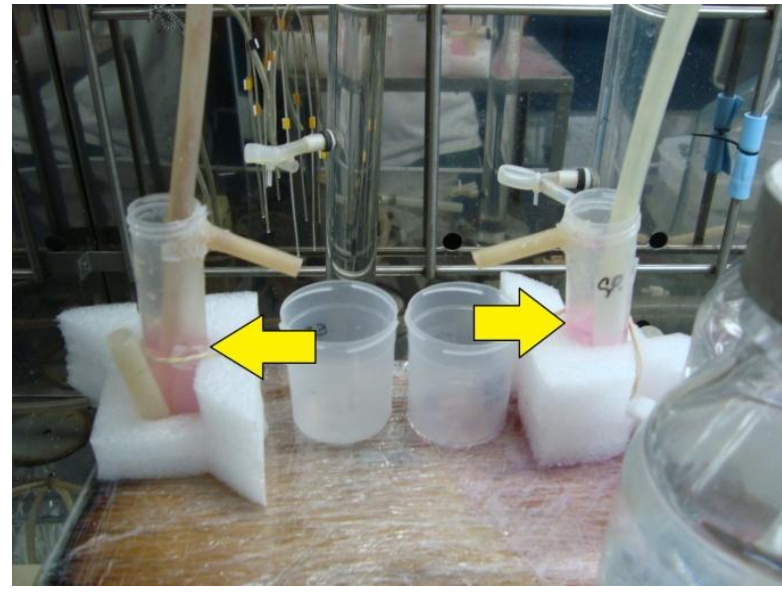

(b)

Figura 5.42: Coloração do efluente após a adição de resazurina no reator $\mathrm{R}_{\mathrm{S} 1}$ (a) e coletor de efluente dos reatores $\mathrm{R}_{\mathrm{L} 1}$ e $\mathrm{R}_{\mathrm{S} 1}$ (b)

Ao fim do ensaio, observou-se maior concentração de LAS adsorvido no reator com água residuária sintética $\left(\mathrm{R}_{\mathrm{S} 1}: 39-70 \mathrm{mg} / \mathrm{g} \mathrm{ST}\right)$ que no reator com água residuária de lavanderia ( $\left.\mathrm{R}_{\mathrm{L} 1}: 12-23 \mathrm{mg} / \mathrm{g} \mathrm{ST}\right)$ (Tabela 5.14). Todavia, a concentração de LAS adsorvido no SST efluente foi maior no reator $\mathrm{R}_{\mathrm{L} 1}(18 \mathrm{mg} \mathrm{LAS} / \mathrm{g} \mathrm{ST})$. Algumas ressalvas devem ser feitas com relação à concentração de LAS adsorvido no SST efluente: a quantidade de SST coletada permitiu a determinação em amostra única; e durante o tempo de coleta (15 dias) parte do LAS adsorvido pode ter degradado. Realizou-se outra tentativa na Parte 2, a fim de comparar os resultados obtidos.

Tabela 5.14: Concentração de LAS adsorvido na Parte 1

\begin{tabular}{lcc}
\hline LAS adsorvido & $\begin{array}{c}\mathrm{R}_{\mathrm{L} 1} \\
(\mathrm{mg} / \mathrm{g} \mathrm{ST})\end{array}$ & $\begin{array}{c}\mathrm{R}_{\mathrm{S} 1} \\
(\mathrm{mg} / \mathrm{g} \mathrm{ST})\end{array}$ \\
\hline Manta de lodo - Início & $2,8 \pm 0,3$ & $2,8 \pm 0,3$ \\
Manta de lodo - Fim & $23 \pm 2$ & $70 \pm 7$ \\
Separador de fases - Fim & $12 \pm 5$ & $39 \pm 3$ \\
SST efluente & $18 \pm 3$ & $1,5 \pm 1,0$
\end{tabular}

Após o fechamento do separador de fases no $27^{\circ}$ dia de operação observou-se aumento da concentração de LAS efluente em ambos os reatores. No reator $\mathrm{R}_{\mathrm{L} 1}$, a concentração de LAS efluente aumentou de 0,5 mg/L para $3 \mathrm{mg} / \mathrm{L}$ (Figura 5.43a). Após 20 dias, observou-se 
concentração de LAS efluente no reator $R_{\mathrm{L} 1}$ menor que $2 \mathrm{mg} / \mathrm{L}$. No reator $\mathrm{R}_{\mathrm{S} 1}$ observou-se também aumento da concentração de LAS efluente de $3 \mathrm{mg} / \mathrm{L}$ até 7,5 mg/L (Figura 5.43b). Após 20 dias observou-se decréscimo da concentração de LAS para $4 \mathrm{mg} / \mathrm{L}$, porém, ao final do ensaio, observou-se outro aumento até $7 \mathrm{mg} / \mathrm{L}$. Atribuiu-se esse aumento ao final do ensaio à oscilação da concentração de LAS afluente no reator $\mathrm{R}_{\mathrm{S} 1}$ (aumento de 10 para $13 \mathrm{mg} / \mathrm{L}$ ), resultando em decréscimo da remoção de DQO para menos de $15 \%$ e redução do pH efluente para 6,9 .

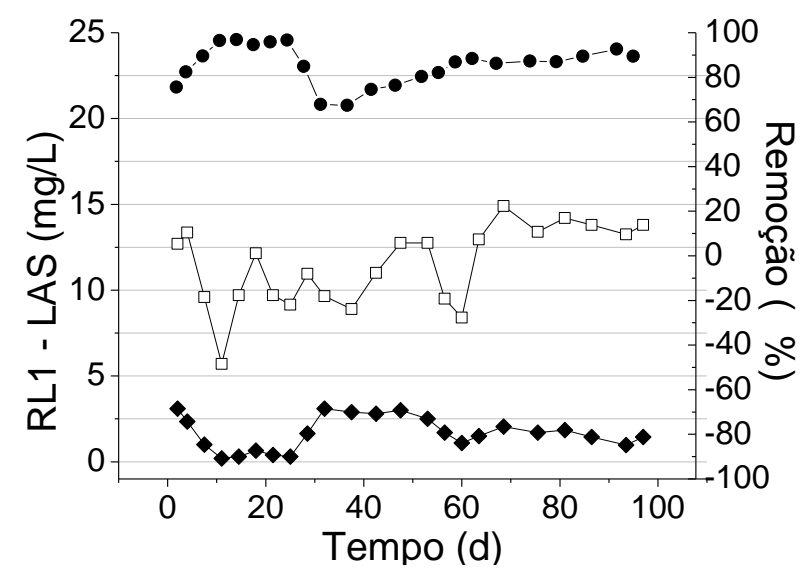

(a)

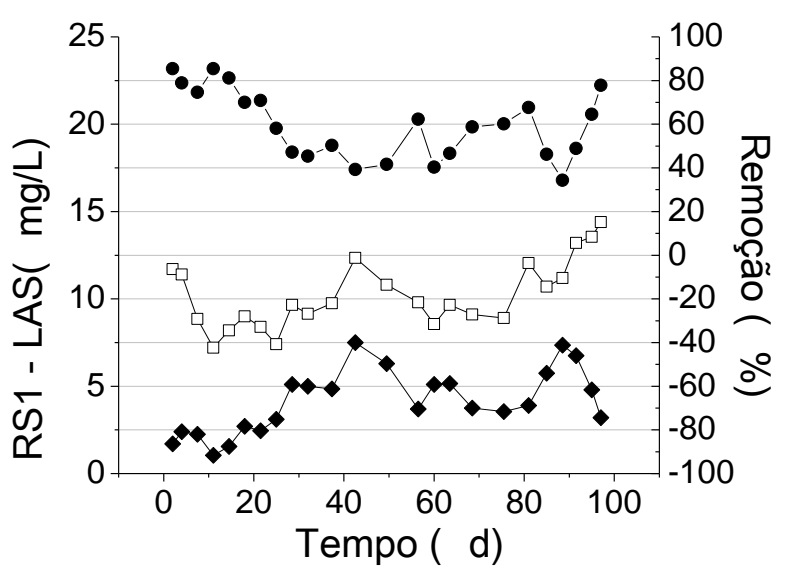

(b)

Figura 5.43: Variação temporal de LAS afluente $(\square)$, efluente $(\bullet)$ e remoção $(\bullet)$, nos reatores $\mathrm{R}_{\mathrm{L} 1}$ (a) e $\mathrm{R}_{\mathrm{S} 1}$ (b)

Obteve-se, mediante balanço de massa, a maior eficiência de degradação de LAS no reator alimentado com água residuária de lavanderia $\left(\mathrm{R}_{\mathrm{L} 1}\right)$. No reator $\mathrm{R}_{\mathrm{L} 1}$ e $\mathrm{R}_{\mathrm{S} 1}$ observou-se degradação de $82 \%$ e $45 \%$, respectivamente (Figura 5.44). Comparando os dois reatores, observou-se que a parcela de LAS no efluente foi 2,4 vezes maior no reator com água residuária sintética $\left(\mathrm{R}_{\mathrm{S} 1}\right)$ (Tabela 5.15). Além disso, o total da parcela de LAS adsorvida no reator $\mathrm{R}_{\mathrm{S} 1}$ foi quase quatro vezes maior que no reator $\mathrm{R}_{\mathrm{L} 1}$. A parcela de LAS adsorvida na biomassa foi desprezível, correspondendo a menos de $0,1 \%$ do total adicionado aos reatores. 
Tabela 5.15: Balanço de massa de LAS na Parte 1

\begin{tabular}{lcc}
\hline Balanço de massa & $\mathrm{R}_{\mathrm{L} 1}$ & $\mathrm{R}_{\mathrm{S} 1}$ \\
\hline Adicionado (mg) & 451,7 & 422,5 \\
Adsorvido biomassa - inicial (mg) & 0,3 & 0,3 \\
Efluente (dissolvido) (mg) & 66,1 & 171,5 \\
Adsorvido (mg) & & \\
Manta de lodo & 3,5 & 42,9 \\
Separador de fases & 2,7 & 15,6 \\
SST efluente & 8,9 & 0,9 \\
Total Adsorvido & 15,2 & 59,4 \\
Degradado (mg) & 370,6 & 191,9 \\
Degradado (\%) & $82 \pm 9$ & $45 \pm 16$ \\
Carga específica de LAS (mg/g STV.d) & 16,0 & 13,1 \\
Degradação específica de LAS (mg/g STV.d) & 13,3 & 6,0 \\
Duração (d) & 97 & 97 \\
\hline
\end{tabular}

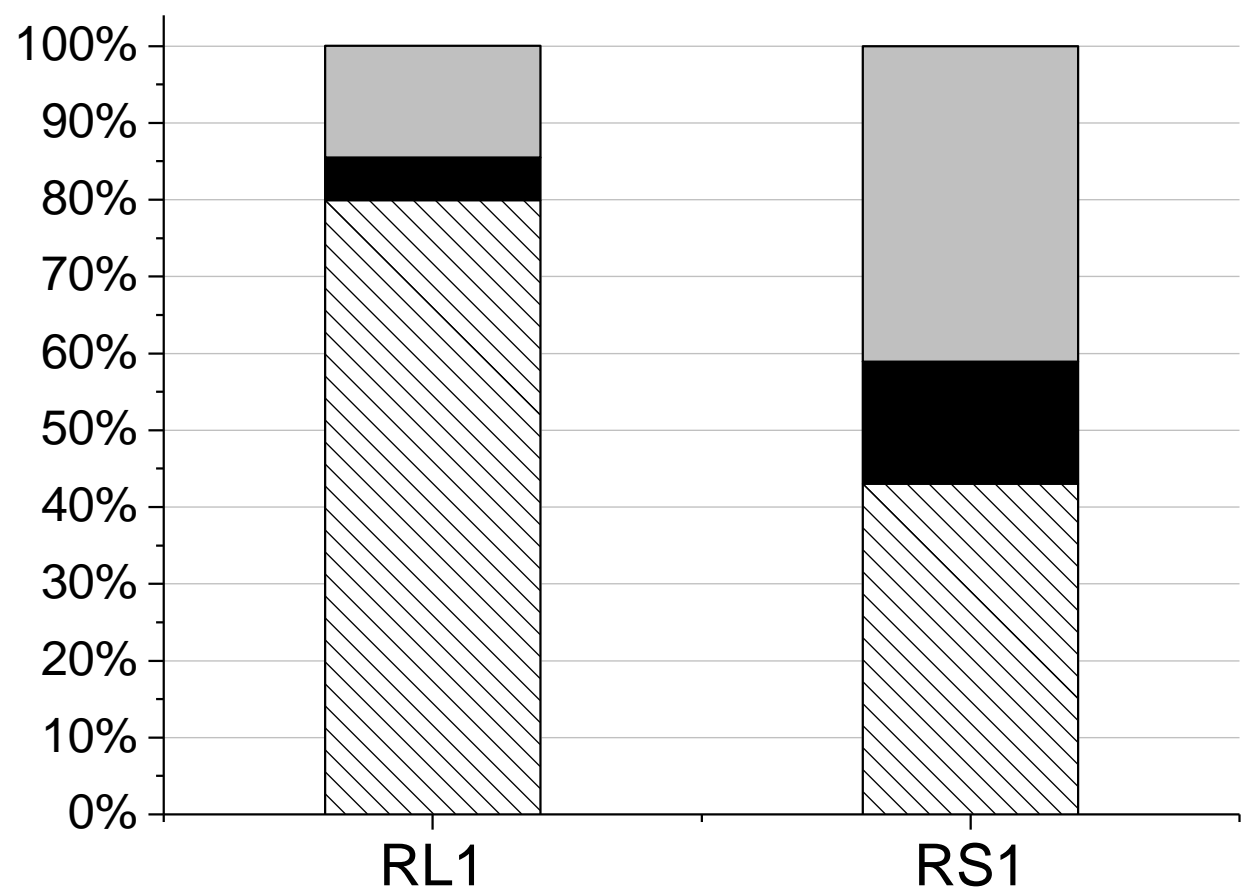

Figura 5.44: Distribuição do destino final de LAS nos reatores $R_{L 1}$ e $R_{S 1}$ : efluente $(\square)$, adsorvido na biomassa $(\mathbf{\square})$ e degradado $(\mathbb{\mathbb { Q }})$

A carga e degradação específica de LAS dos reatores $R_{L 1}$ e $R_{S 1}$ foram comparadas com a equação 5.1 (item 5.3), determinada em TDH similar (35 h) (Figura 5.45). Para o reator $\mathrm{R}_{\mathrm{S} 1}$, observou-se pouca diferença entre a degradação específica de LAS obtida e a prevista pela equação 5.1 (7\% de variação relativa). Todavia, verificou-se degradação específica de LAS maior que a esperada pela equação $5.1(70 \%)$ no reator $\mathrm{R}_{\mathrm{L} 1}$. 


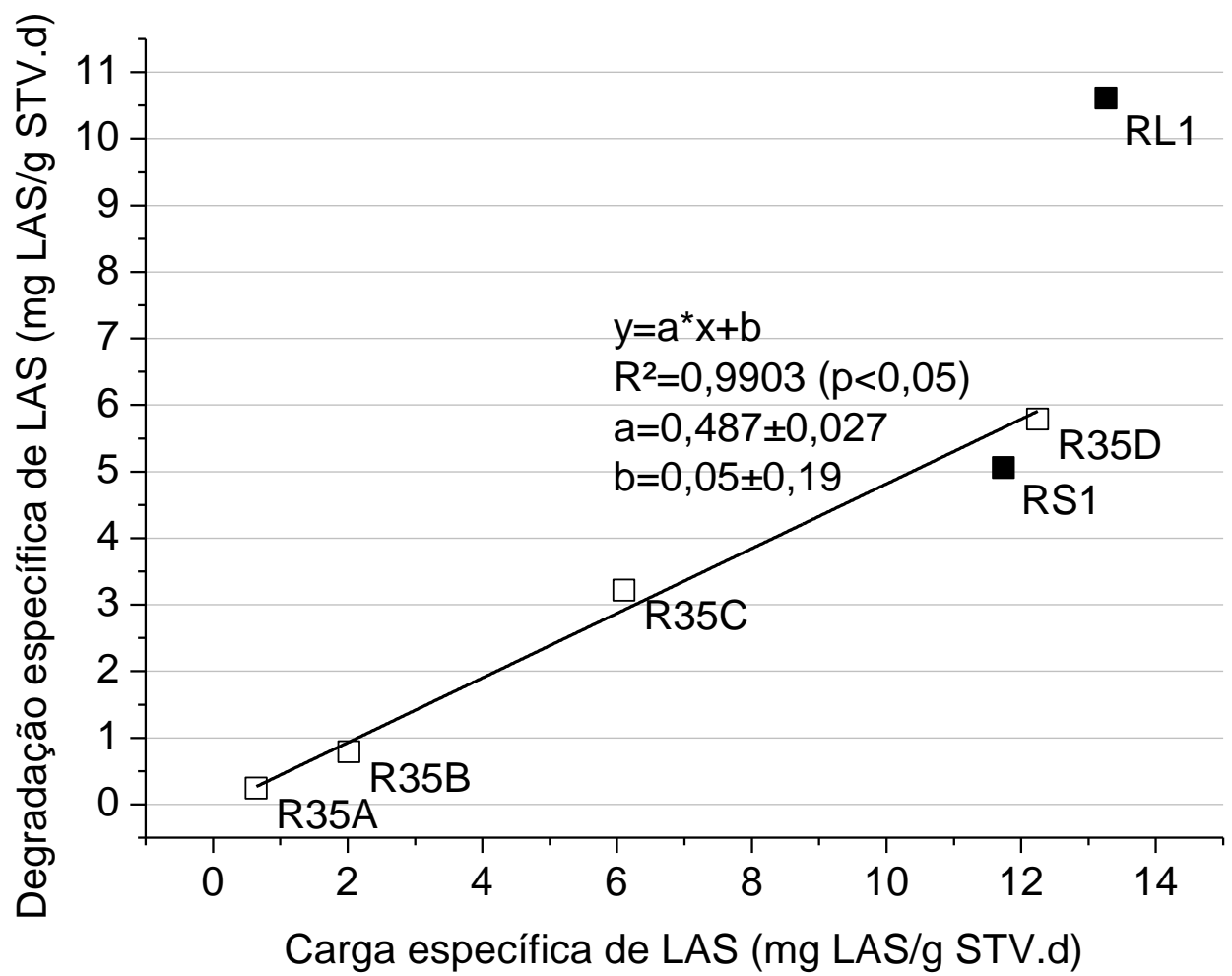

Figura 5.45: Degradação específica de LAS em função da carga específica de LAS nos reatores $R_{L 1}$ e $R_{S 1}(\square)$ comparada com a equação 5.1 (regressão linear dos reatores $R_{35 A}, R_{35 B}$, $\mathrm{R}_{35 \mathrm{C}}$ e $\mathrm{R}_{35 \mathrm{D}}$; $\square$; item 5.3)

Atribuiu-se a maior degradação de LAS no reator $\mathrm{R}_{\mathrm{L} 1}$ a dois aspectos: $(i)$ a diversidade de co-substratos, considerando a quantidade de ácidos orgânicos voláteis detectados (12) na caracterização da água de lavanderia comercial (Figura 5.33, p. 99); (ii) a baixa concentração de co-substratos disponíveis, considerando a DQO correspondente aos ácidos orgânicos voláteis na água de lavanderia. A média de ácidos orgânicos voláteis da água residuária de

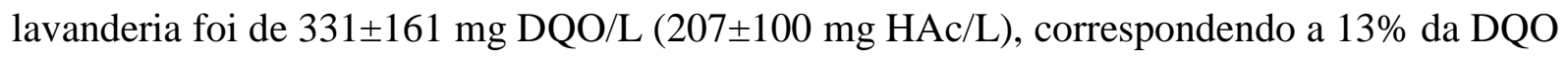
bruta $(2.572 \pm 916 \mathrm{mg} / \mathrm{L})$. Assim, da carga orgânica específica de 0,20 g DQO/g STV.d observada no reator $\mathrm{R}_{\mathrm{L} 1}$, apenas $0,03 \mathrm{~g} \mathrm{DQO/g} \mathrm{STV.d} \mathrm{foi} \mathrm{equivalente} \mathrm{aos} \mathrm{ácidos} \mathrm{orgânicos}$ voláteis. Esse valor de carga orgânica específica foi similar ao aplicado no reator $\mathrm{R}_{\mathrm{BCS}}$, que apresentou a maior degradação de LAS (76\%) no item 5.3 (p. 83). 


\subsubsection{Variação espacial}

Observou-se maior produção de ácidos orgânicos voláteis em diferentes pontos dos reatores $\mathrm{R}_{\mathrm{L} 1}$ e $\mathrm{R}_{\mathrm{S} 1}$. No reator $\mathrm{R}_{\mathrm{S} 1}$ a concentração de ácidos orgânicos voláteis antes do ponto PA1, que estava abaixo de $17 \mathrm{mg} \mathrm{HAc/L}$, aumentou para $43 \mathrm{mg}$ HAc/L (Figura 5.46). No reator $\mathrm{R}_{\mathrm{L} 1}$, observou-se aumento da concentração de ácidos orgânicos voláteis na região do separador de fases, de $8 \mathrm{mg} \mathrm{HAc/L}$, no ponto PA3, para $42 \mathrm{mg} \mathrm{HAc/L}$, no efluente. Esse aumento foi relacionado com a remoção de LAS no separador de fases do reator $\mathrm{R}_{\mathrm{L} 1}(90 \%$; entre o ponto PA3 e efluente), indicando biotransformação do surfactante em ácidos orgânicos voláteis (Figura 5.47).

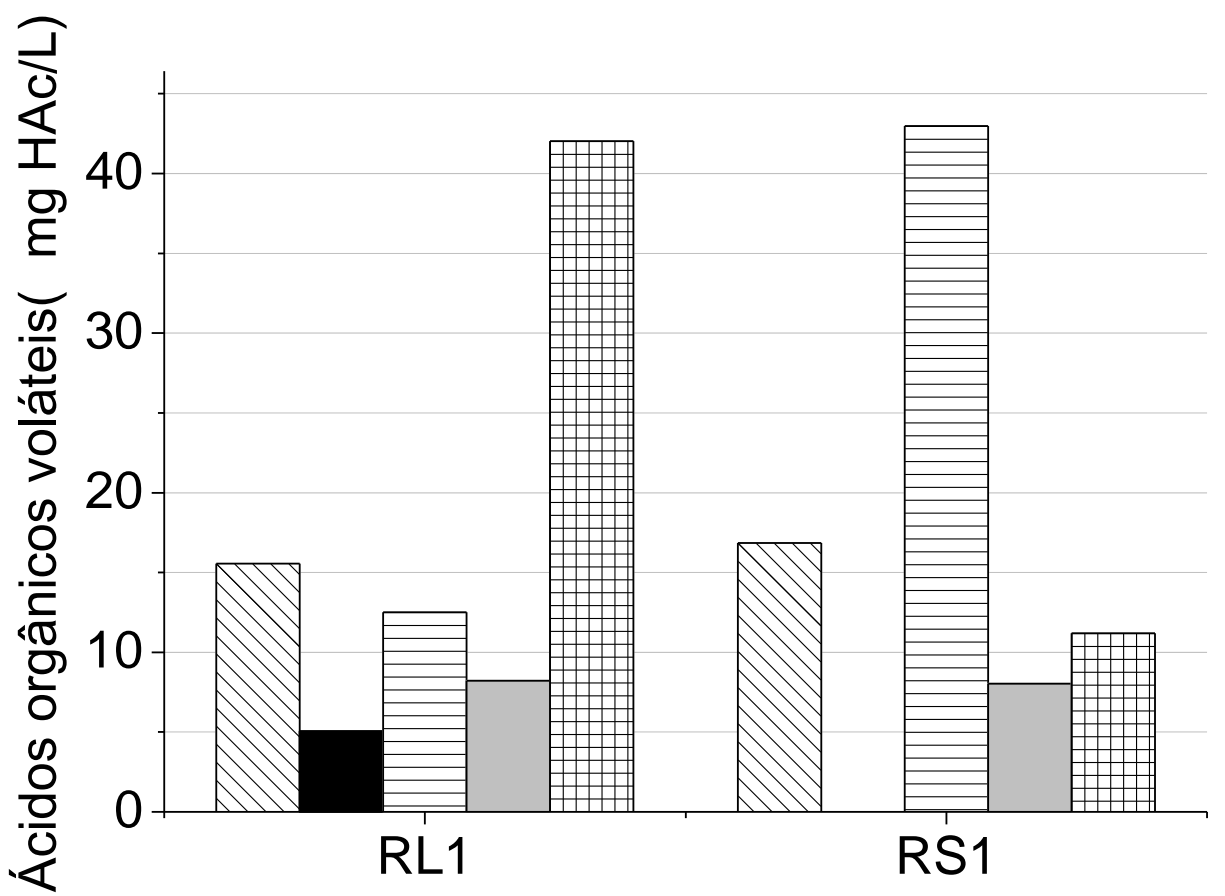

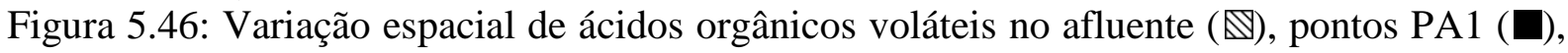
PA2 (目), PA3 ( $\square$ ) e efluente (曲), nos reatores $\mathrm{R}_{\mathrm{L} 1}$ e $\mathrm{R}_{\mathrm{S} 1}$

A remoção de LAS foi maior na região do separador de fases dos dois reatores, com eficiências de 90 e $55 \%$ nos reatores $R_{L 1}$ e $R_{S 1}$, respectivamente (Figura 5.47). Não foi observada remoção de LAS na manta de lodo do reator $R_{L 1}$, enquanto, no reator $R_{S 1}$ verificou- 
se eficiência de cerca de $20 \%$. Comparando com a relação entre concentração de ácidos orgânicos voláteis no ponto PA3 e a remoção de LAS no separador de fases do item 5.3.5, verificou-se que a remoção de surfactante no reator com água de lavanderia $\left(\mathrm{R}_{\mathrm{L} 1}\right)$ foi maior que nos demais reatores (Figura 5.48).

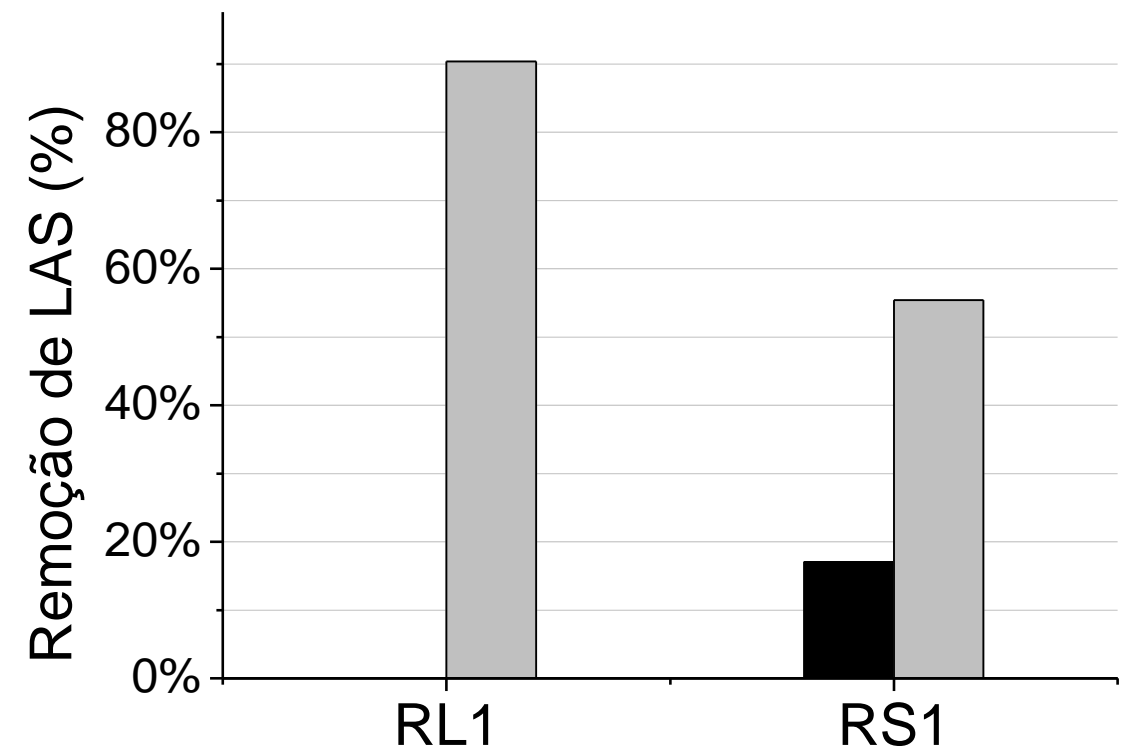

Figura 5.47: Remoção de LAS na manta de lodo ( $\square$ ) e no separador de fases ( $\square$ ), nos reatores $\mathrm{R}_{\mathrm{L} 1}$ e $\mathrm{R}_{\mathrm{S} 1}$ 


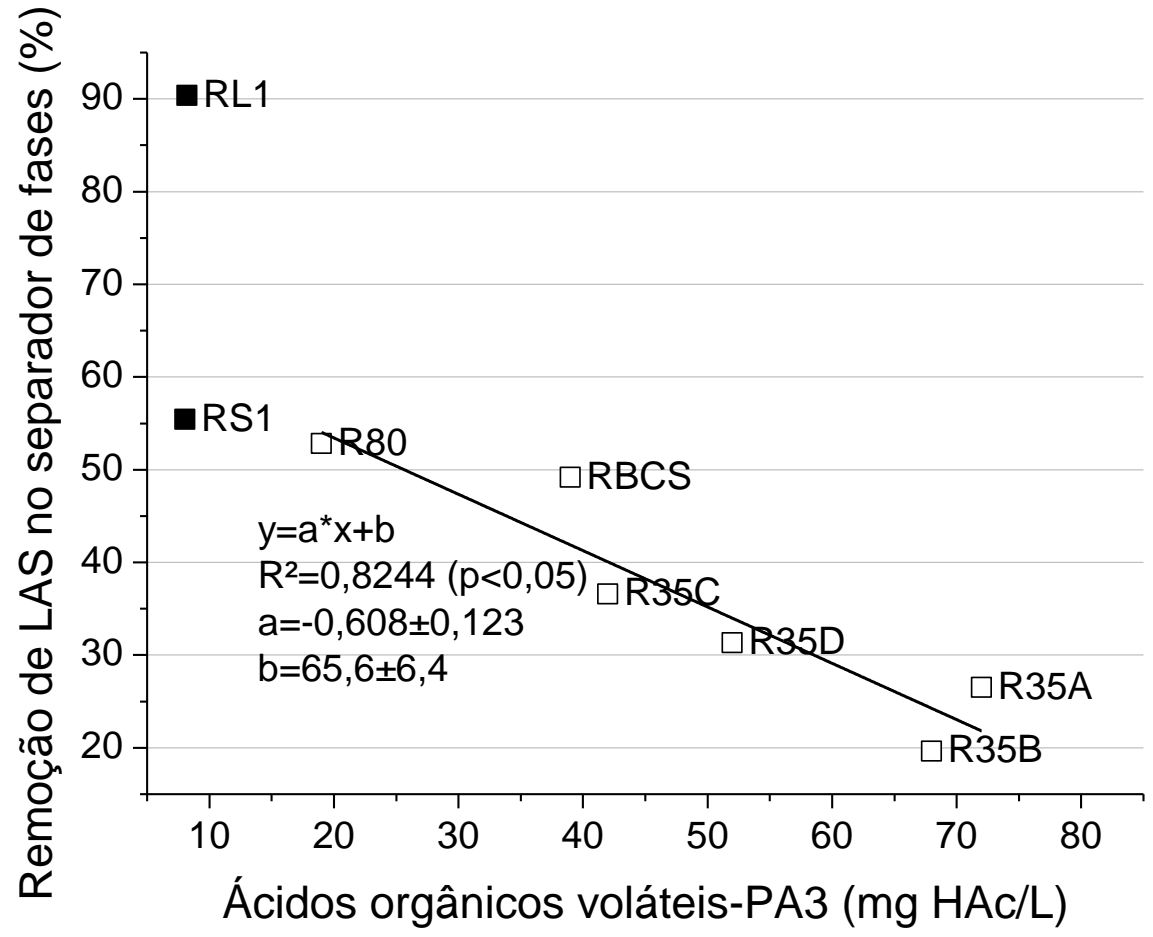

Figura 5.48: Remoção de LAS no separador de fases em função da concentração de ácidos orgânicos voláteis no ponto PA3 dos reatores $\mathrm{R}_{\mathrm{L} 1}$ e $\mathrm{R}_{\mathrm{S} 1}$, comparada com dados dos reatores $\mathrm{R}_{35 \mathrm{~A}}, \mathrm{R}_{35 \mathrm{~B}}, \mathrm{R}_{35 \mathrm{C}}, \mathrm{R}_{35 \mathrm{D}}, \mathrm{R}_{\mathrm{BCS}}$ e $\mathrm{R}_{80}$ ( $\square$; item 5.3)

Destacou-se a importância da comunidade microbiana desenvolvida na biomassa do separador de fases do reator $\mathrm{R}_{\mathrm{L} 1}$, em virtude da alta remoção de LAS $(90 \%)$ e do aumento da concentração de ácidos orgânicos voláteis (de $8 \mathrm{mg} \mathrm{HAc/L}$ para $42 \mathrm{mg}$ HAc/L) observados nessa região, indicando biotransformação do surfactante. Além disso, verificou-se para o reator $\mathrm{R}_{\mathrm{L} 1}$ a maior eficiência de degradação de LAS (82\%) no presente estudo (eficiências nos demais reatores: $18-76 \%$ ), evidenciando a maior capacidade de degradação do surfactante pela comunidade microbiana presente nesse reator. 


\subsubsection{Monitoramento - Parte 2}

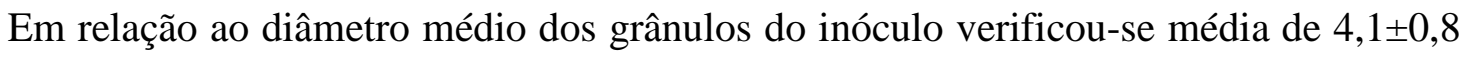
mm no reator $R_{L 2}$, e $4,1 \pm 0,7 \mathrm{~mm}$ no reator $R_{S 2}$. Não se observou mudança significativa do

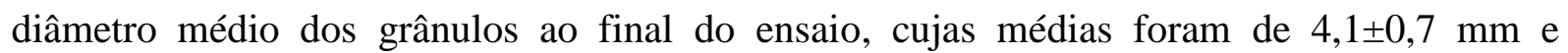
4,0 $\pm 0,7$ mm para os grânulos dos reatores $\mathrm{R}_{\mathrm{L} 2}$ e $\mathrm{R}_{\mathrm{S} 2}$, respectivamente (Figura 5.49 e Figura 5.50). Além disso, os valores do $1^{\circ}$ e $3^{\circ}$ quartil do box-plot de distribuição variaram entre 3,5 e 4,5 mm nas quatro medidas (inicial e final, dos reatores $R_{L 2}$ e $R_{S 2}$ ), indicando variação desprezível entre as quatro medidas.

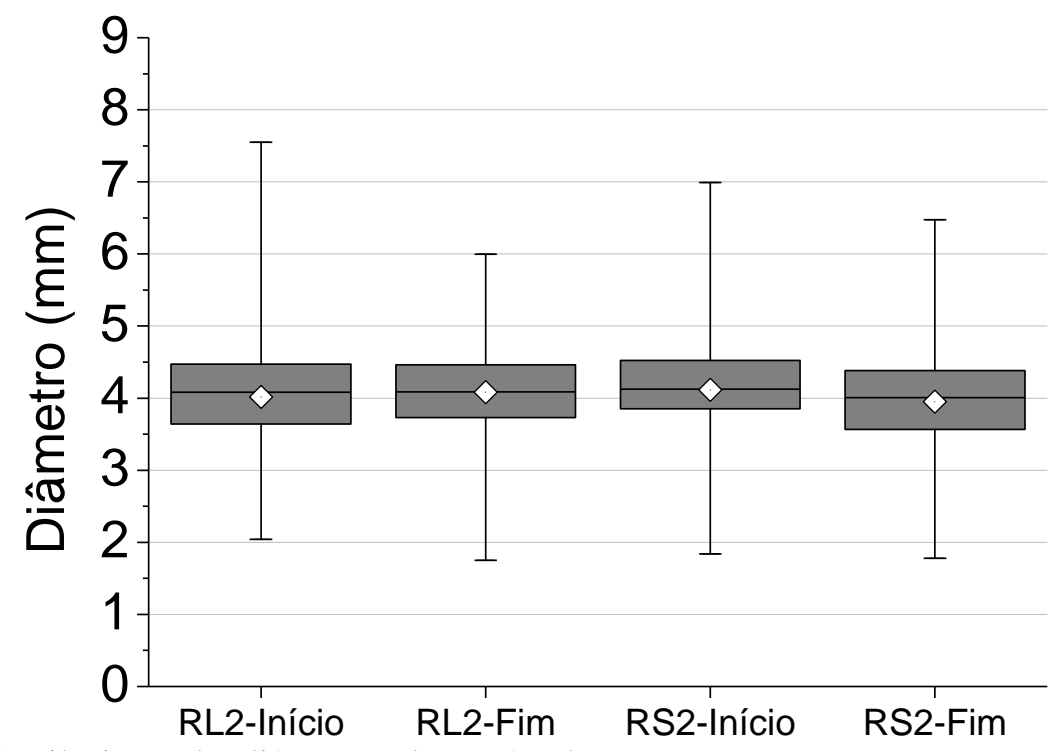

Figura 5.49: Distribuição do diâmetro dos grânulos nos reatores $\mathrm{R}_{\mathrm{L} 2}$ e $\mathrm{R}_{\mathrm{S} 2}$ no início e fim do ensaio, em amostra de 400 grânulos 


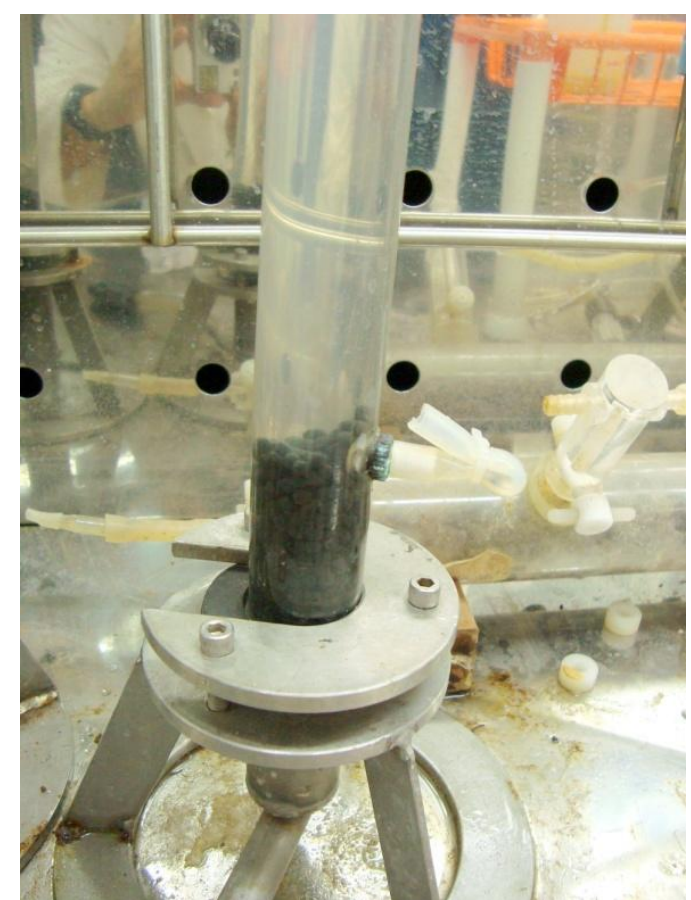

Figura 5.50: Manta de lodo do reator $\mathrm{R}_{\mathrm{L} 2}$ ao final do ensaio

Observou-se pouca variação entre o $\mathrm{pH}$ (afluente: 7,9-8,2; efluente: 7,4-7,6) das Etapas 2.1 e 2.2 do reator $\mathrm{R}_{\mathrm{L} 2}$ e no reator $\mathrm{R}_{\mathrm{S} 2}$ (Tabela 5.16). A alcalinidade total também variou pouco entre as Etapas 2.1 e 2.2 do reator $\mathrm{R}_{\mathrm{L} 2}$ e no reator $\mathrm{R}_{\mathrm{S} 2}$ (afluente: 423$536 \mathrm{mg} \mathrm{CaCO}_{3} / \mathrm{L}$; efluente: 447-534 $\left.\mathrm{mg} \mathrm{CaCO}_{3} / \mathrm{L}\right)$. 
Tabela 5.16: Parâmetros analisados na Parte 2

\begin{tabular}{|c|c|c|c|}
\hline \multirow[t]{2}{*}{ Parâmetro } & \multicolumn{2}{|c|}{$\mathrm{R}_{\mathrm{L} 2}$} & \multirow[t]{2}{*}{$\mathrm{R}_{\mathrm{S} 2}$} \\
\hline & Etapa 2.1 & Etapa 2.2 & \\
\hline \multicolumn{4}{|l|}{ Ácidos orgânicos voláteis (mg HAc/L) } \\
\hline Efluente & $8 \pm 6$ & $16 \pm 14$ & $13 \pm 12$ \\
\hline \multicolumn{4}{|l|}{ Alcalinidade $\left(\mathrm{mg} \mathrm{CaCO}_{3} / \mathrm{L}\right)$} \\
\hline \multicolumn{4}{|l|}{ Afluente } \\
\hline Parcial & $382 \pm 70$ & $318 \pm 33$ & $419 \pm 83$ \\
\hline Total & $491 \pm 80$ & $423 \pm 36$ & $536 \pm 98$ \\
\hline \multicolumn{4}{|l|}{ Efluente } \\
\hline Parcial & $376 \pm 41$ & $336 \pm 32$ & $412 \pm 52$ \\
\hline Total & $491 \pm 46$ & $447 \pm 34$ & $534 \pm 61$ \\
\hline \multicolumn{4}{|l|}{ Biomassa no reator (g/L) } \\
\hline ST & - & $2,4 \pm 0,8$ & $2,1 \pm 0,7$ \\
\hline STV & - & $1,7 \pm 0,4$ & $1,5 \pm 0,3$ \\
\hline STF & - & $0,7 \pm 0,2$ & $0,6 \pm 0,1$ \\
\hline \multicolumn{4}{|l|}{ DQO bruta } \\
\hline Afluente (mg/L) & $123 \pm 43$ & $150 \pm 92$ & $218 \pm 93$ \\
\hline Efluente (mg/L) & $41 \pm 12$ & $63 \pm 39$ & $65 \pm 14$ \\
\hline Remoção (\%) & $65 \pm 9$ & $58 \pm 10$ & $66 \pm 13$ \\
\hline Taxa de carregamento orgânico (kg DQO/m³.d) & $0,10 \pm 0,07$ & $0,11 \pm 0,07$ & $0,16 \pm 0,08$ \\
\hline Carga orgânica específica (g DQO/g STV.d) & $0,06 \pm 0,04$ & $0,06 \pm 0,04$ & $0,11 \pm 0,05$ \\
\hline \multicolumn{4}{|l|}{ LAS } \\
\hline Afluente (mg/L) & $12 \pm 6$ & $14 \pm 5$ & $10 \pm 2$ \\
\hline Efluente (mg/L) & $2 \pm 3$ & $6 \pm 4$ & $6 \pm 2$ \\
\hline \multicolumn{4}{|l|}{$\mathrm{pH}$} \\
\hline Afluente & $8,2 \pm 0,1$ & $8,0 \pm 0,1$ & $7,9 \pm 0,1$ \\
\hline Efluente & $7,5 \pm 0,1$ & $7,6 \pm 0,3$ & $7,4 \pm 0,1$ \\
\hline \multicolumn{4}{|l|}{ SST } \\
\hline Efluente (mg/L) & $8 \pm 5$ & $15 \pm 8$ & $26 \pm 17$ \\
\hline Total descartado no efluente (mg) & - & 650 & 1.390 \\
\hline \multicolumn{4}{|l|}{ Sulfato (mg S/L) } \\
\hline Afluente & - & $40 \pm 17$ & - \\
\hline Efluente & - & $32 \pm 15$ & - \\
\hline \multicolumn{4}{|l|}{ Sulfeto (mg S/L) } \\
\hline Afluente & - & $0,11 \pm 0,06$ & - \\
\hline Efluente & - & $1,7 \pm 1,3$ & - \\
\hline
\end{tabular}

Com relação aos ácidos orgânicos voláteis, foram observadas médias entre 8 e 16 mg HAc/L nos reatores $\mathrm{R}_{\mathrm{L} 2}$ e $\mathrm{R}_{\mathrm{S} 2}$ (Tabela 5.16). Na Etapa 2.1, detectou-se apenas ácido capróico no efluente, com média de $6 \pm 4 \mathrm{mg} / \mathrm{L}$ (Figura 5.51a). Na Etapa 2.2 do reator $\mathrm{R}_{\mathrm{L} 2}$, observou-se aumento para $11 \pm 10 \mathrm{mg} / \mathrm{L}$, de ácido capróico, além da detecção de ácidos propiônico, butírico, valérico e isovalérico, em concentrações menores que $8 \mathrm{mg} / \mathrm{L}$ (Figura 
5.51b). No reator alimentado com água residuária sintética $\left(\mathrm{R}_{\mathrm{S} 2}\right)$ detectou-se ácido fórmico (3 $\pm 7 \mathrm{mg} / \mathrm{L})$, isovalérico $(0,5 \pm 2,0 \mathrm{mg} / \mathrm{L})$ e capróico $(9 \pm 7 \mathrm{mg} / \mathrm{L})$ (Figura $5.51 \mathrm{c})$.

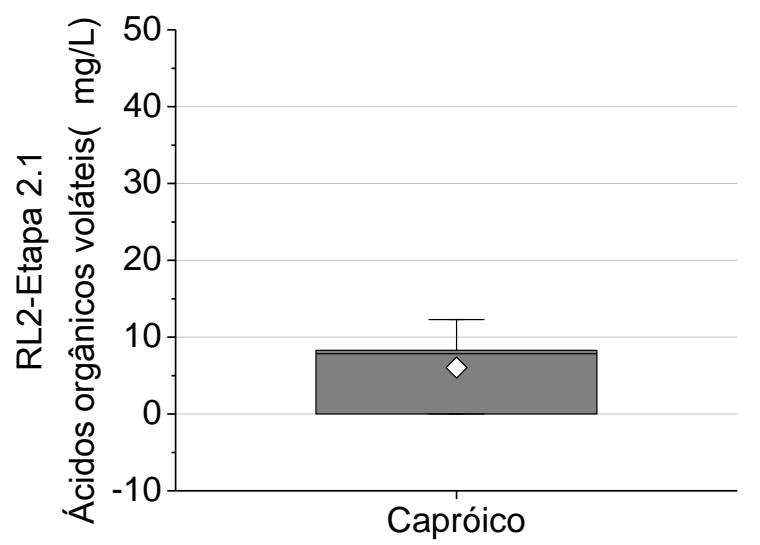

(a)

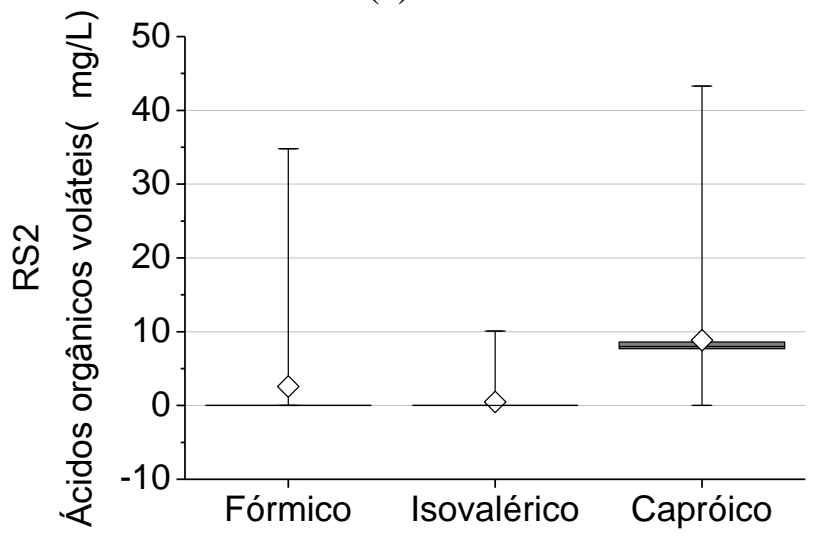

(c)

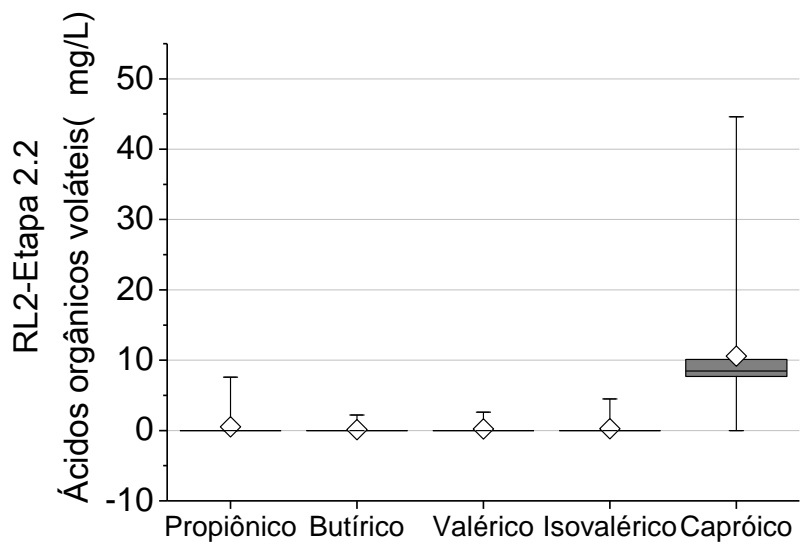

(b)

Figura 5.51: Box-plot de ácidos orgânicos voláteis detectados no efluente dos reatores $\mathrm{R}_{\mathrm{L} 2}-$ Etapa 2.1 (a; em 10 amostras), $\mathrm{R}_{\mathrm{L} 2}$-Etapa 2.2 (b; em 19 amostras) e $\mathrm{R}_{\mathrm{S} 2}$ (c; em 29 amostras)

A DQO aplicada nos reatores oscilou entre 140 e $220 \mathrm{mg} / \mathrm{L}$, sendo observada remoção em torno de $60 \%$ (Tabela 5.16). Observou-se pouca variação na remoção de DQO entre as Etapas 2.1 e 2.2 do reator $\mathrm{R}_{\mathrm{L} 2}$ (de 65 para $58 \%$ ). Devido à concentração de $\mathrm{DQO}$ da água residuária de lavanderia coletada no $52^{\circ}$ dia de operação $(5.200 \mathrm{mg} / \mathrm{L})$, observou-se a maior concentração de DQO afluente (470 mg/L) no reator $\mathrm{R}_{\mathrm{L} 2}$ (Figura 5.52). 


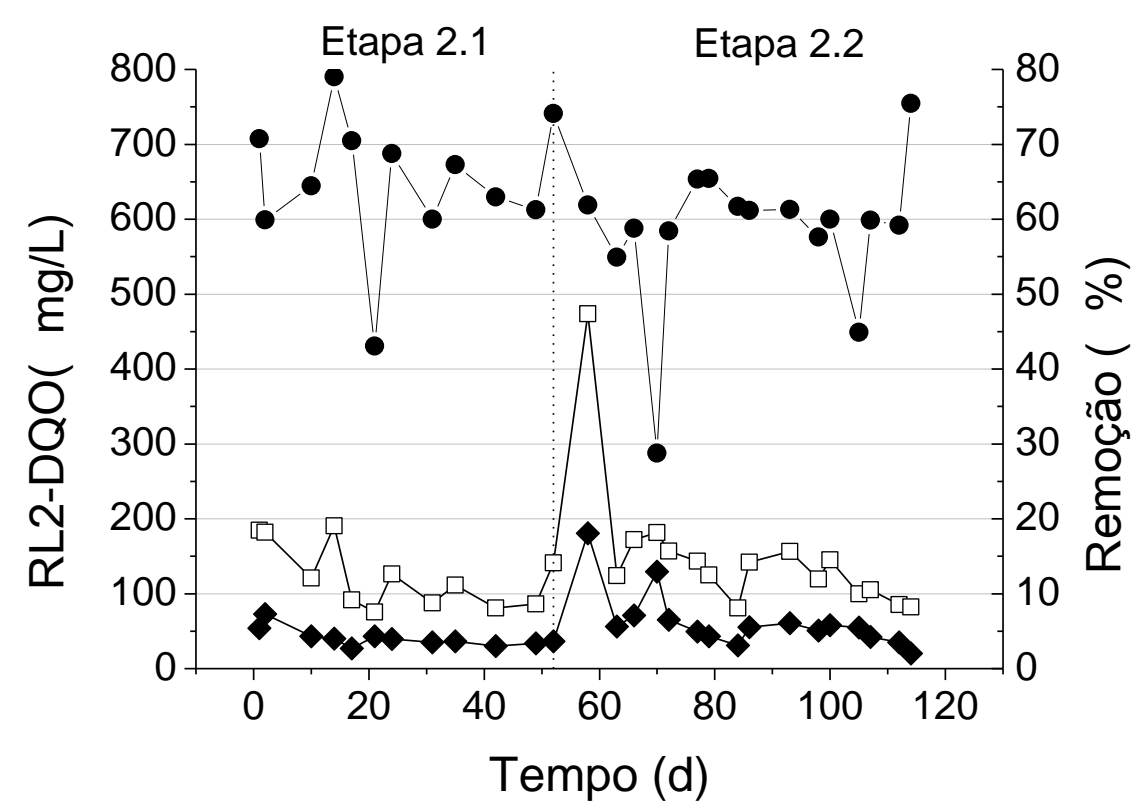

Figura 5.52: Variação temporal de DQO afluente (๑), efluente $(\bullet)$ e remoção $(\bullet)$, no reator $\mathrm{R}_{\mathrm{L} 2}$

No reator $\mathrm{R}_{\mathrm{L} 2}$, observou-se média de SST no efluente de 8 e $15 \mathrm{mg} / \mathrm{L}$, na Etapa 2.1 e 2.2, respectivamente (Tabela 5.16). No reator $\mathrm{R}_{\mathrm{S} 2}$, a concentração média de SST efluente foi maior $(26 \pm 17 \mathrm{mg} / \mathrm{L})$. Em virtude dessa maior concentração de SST, verificou-se maior quantidade de SST descartada no efluente do reator $\mathrm{R}_{\mathrm{S} 2}(1.390 \mathrm{mg})$.

Ao final da operação, observou-se semelhança entre a distribuição de biomassa nos reatores. Os sólidos voláteis na manta de lodo representaram cerca de $60 \%$ do total nos reatores $\mathrm{R}_{\mathrm{L} 2}$ e $\mathrm{R}_{\mathrm{S} 2}$, enquanto, a parcela de sólidos voláteis do separador de fases variou entre 12 e 15\% (Figura 5.53). 


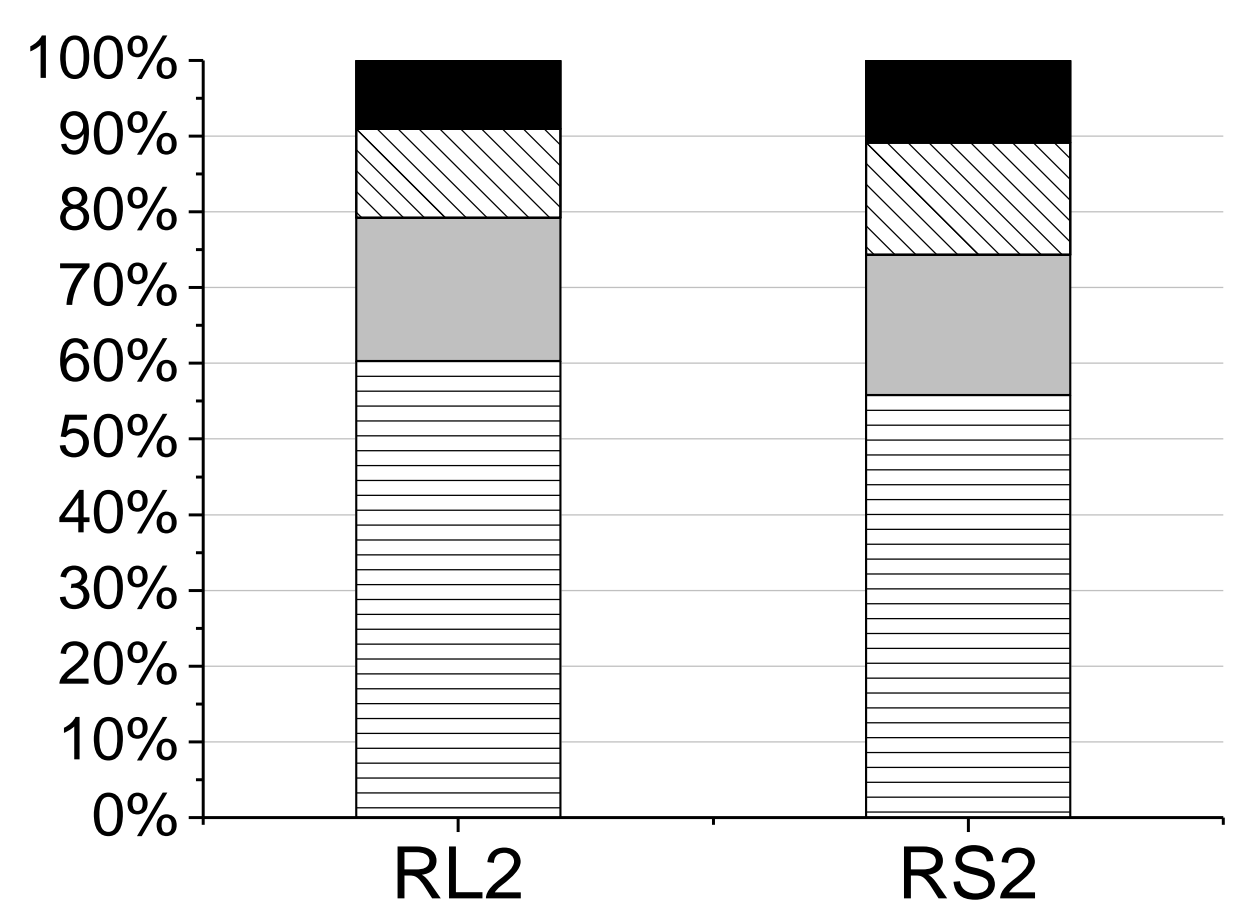

Figura 5.53: Distribuição de sólidos ao final da Parte 2: STV (目) e STF ( $\square$ ) na manta de lodo,

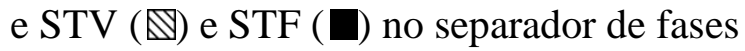

Observou-se decréscimo da remoção de sulfato ao longo da Etapa 2.2. Até o $96^{\circ}$ dia de operação observou-se remoção de sulfato entre 20 e $36 \%$; a partir do $99^{\circ}$ dia observou-se menor remoção de sulfato, entre 12 e $16 \%$.

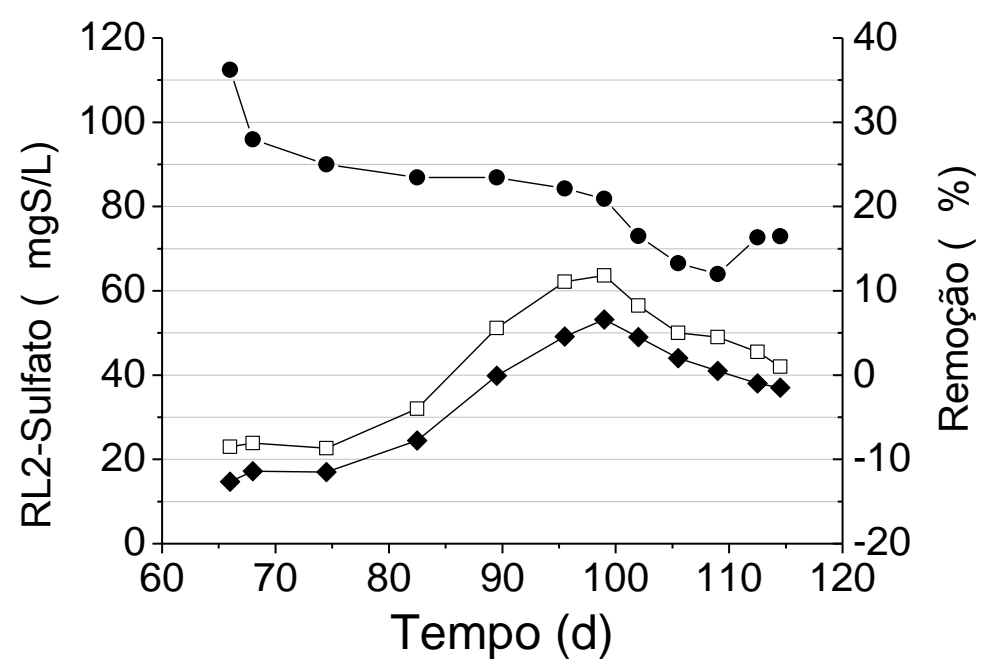

Figura 5.54: Variação temporal de sulfato afluente $(\square)$, efluente $(\bullet)$ e remoção $(\bullet)$, no reator $\mathrm{R}_{\mathrm{L} 2}$ 
Em virtude da menor remoção de sulfato, observou-se decréscimo das concentrações efluente de sulfeto ao longo do ensaio. Até o $83^{\circ}$ dia de operação (sulfato afluente: 23-32 mg S/L), observou-se a redução de sulfeto efluente de 3 para 0,7 mg S/L (Figura 5.55). Com o aumento da concentração de sulfato afluente (40-64 mg S/L, a partir do 90 dia; Figura 5.54), observou-se aumento do sulfeto efluente para $2,5 \mathrm{mg} \mathrm{S} / \mathrm{L}$ no $90^{\circ}$ dia. A partir do $96^{\circ}$ dia, observou-se novamente a redução de sulfeto, de 3 para $0,1 \mathrm{mg} \mathrm{S} / \mathrm{L}$ até o fim do ensaio.

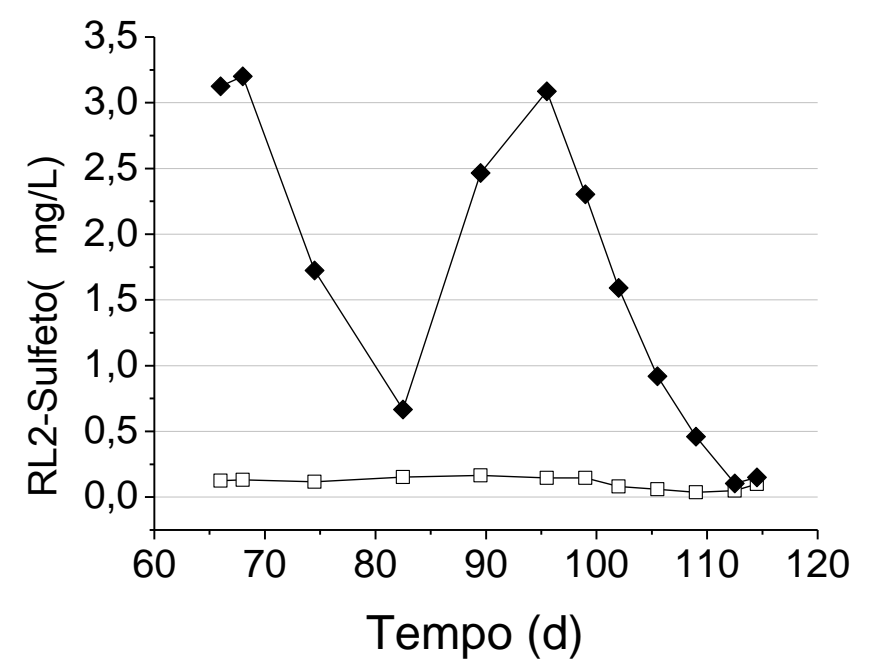

Figura 5.55: Variação temporal de sulfeto afluente $(\square)$ e efluente $(\diamond)$, no reator $\mathrm{R}_{\mathrm{L} 2}$

Na Etapa 2.1 do reator $R_{\mathrm{L} 2}$, observou-se variação da remoção de LAS entre 60 e $95 \%$ (média: $79 \pm 11 \%$ ), em virtude da adsorção ao lodo granulado e da oscilação da concentração de LAS afluente entre 6 e $20 \mathrm{mg} / \mathrm{L}$ (Figura 5.56a). Na Etapa 2.2 do reator $\mathrm{R}_{\mathrm{L} 2}$, atribuiu-se a variação da remoção de LAS, entre 35 e $80 \%$ (média: 61士16\%), à oscilação da concentração de LAS afluente (15-21 mg/L). Observou-se maior remoção de LAS na Etapa 2.1 (79\%) que na Etapa $2.1(61 \%)$ do reator $\mathrm{R}_{\mathrm{L} 2}$, em virtude da influência da adsorção na Etapa 2.1 e da menor concentração média afluente de LAS (Etapa 2.1: $12 \pm 6 \mathrm{mg} / \mathrm{L}$; Etapa 2.2: $14 \pm 5 \mathrm{mg} / \mathrm{L}$ ). 


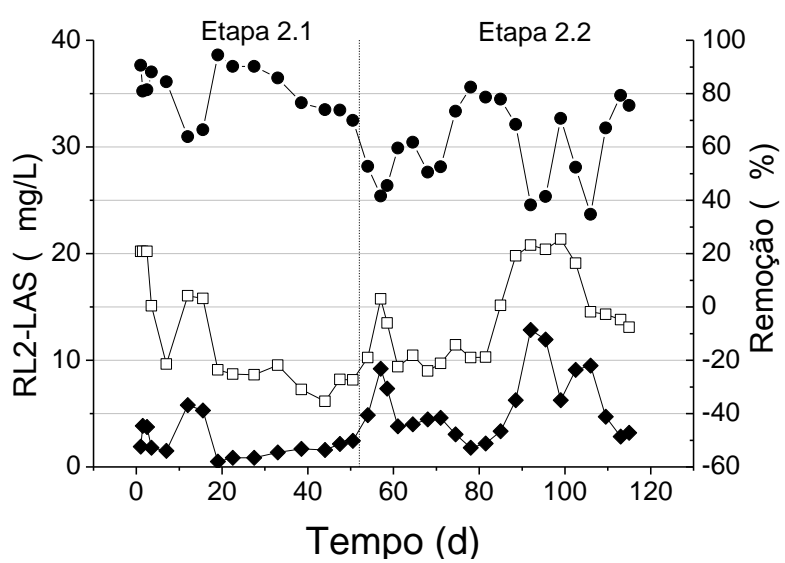

(a)

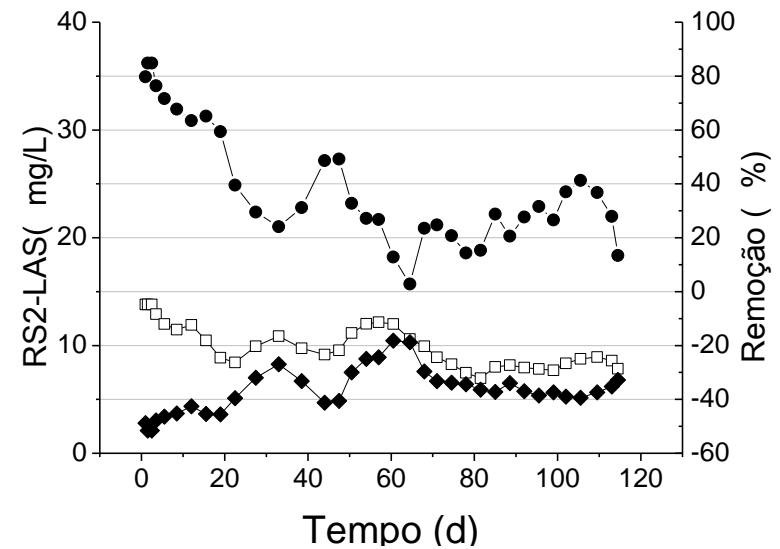

(b)

Figura 5.56: Variação temporal de LAS afluente $(\square)$, efluente $(\bullet)$ e remoção $(\bullet)$, nos reatores $\mathrm{R}_{\mathrm{L} 2}$ (a) e $\mathrm{R}_{\mathrm{S} 2}$ (b)

Observou-se decréscimo da remoção de LAS no reator $\mathrm{R}_{\mathrm{S} 2}$ ao longo do tempo (Figura 5.56b). Nos primeiros 20 dias a média de remoção de LAS foi de $70 \pm 9 \%$, reduzindo para valores entre 25 e $50 \%$ (entre o $20^{\circ}$ e $60^{\circ}$ dia de operação) devido à adsorção ao lodo granulado. A partir do $65^{\circ}$ dia de operação, observou-se eficiência de remoção de LAS entre 3 e $40 \%$.

Ao final do ensaio observou-se pouca diferença entre as concentrações de LAS adsorvido. Em relação à concentração de LAS adsorvido observou-se variação entre 27 e 35 mg/g ST na manta de lodo, e entre 19 e $30 \mathrm{mg} / \mathrm{g}$ ST no separador de fases (Tabela 5.17). As concentrações de LAS adsorvido nos sólidos suspensos foram menores em ambos os reatores $\left(\mathrm{R}_{\mathrm{L} 2}: 17 \mathrm{mg} / \mathrm{g} \mathrm{ST} ; \mathrm{R}_{\mathrm{S} 2}: 7 \mathrm{mg} / \mathrm{g} \mathrm{ST}\right)$.

Novamente, realizou-se a determinação da concentração de LAS adsorvido em amostra única, em virtude da dificuldade em conseguir quantidade suficiente de sólidos suspensos. Apesar disso, observou-se menor diferença entre as concentrações de LAS adsorvido na manta de lodo, separador de fases e sólidos suspensos. No reator $\mathrm{R}_{\mathrm{L} 2}$ observouse de 17 a 35 mg/g ST de LAS adsorvido, enquanto, no reator $\mathrm{R}_{\mathrm{S} 2}$ foram observados valores entre 7 e $27 \mathrm{mg} / \mathrm{g} \mathrm{ST}$. Considerando os resultados do item 5.4.2, verificou-se que o procedimento usado para determinação da concentração de LAS adsorvido foi adequado para 
estimar a parcela de surfactante adsorvida no efluente. Entretanto, outras medidas devem ser adotadas para aumentar a precisão, principalmente, para coletar amostras em quantidade suficiente para determinação em replicatas e reduzir o tempo de coleta da amostra.

\begin{tabular}{lcc}
\multicolumn{3}{c}{ Tabela 5.17: Concentração de LAS adsorvido na Parte 2 } \\
\hline LAS adsorvido & $\mathrm{R}_{\mathrm{L} 2}$ & $\mathrm{R}_{\mathrm{S} 2}$ \\
$(\mathrm{mg} / \mathrm{g} \mathrm{ST})$ & $(\mathrm{mg} / \mathrm{g} \mathrm{ST})$ \\
\hline Manta de lodo - Início & $2,8 \pm 0,3$ & $2,8 \pm 0,3$ \\
Manta de lodo - Fim & $35 \pm 6$ & $26,7 \pm 0,5$ \\
Separador de fases - Fim & $30 \pm 3$ & $19 \pm 2$ \\
SST efluente & $17 \pm 3$ & $7 \pm 1$
\end{tabular}

Por meio do balanço de massa obteve-se eficiência de degradação de $58 \%$ e $27 \%$, nos reatores $\mathrm{R}_{\mathrm{L} 2}$ e $\mathrm{R}_{\mathrm{S} 2}$, respectivamente (Figura 5.57). Observou-se pouca diferença na parcela adsorvida dos dois reatores (cerca de 10\%), com total de LAS adsorvido de $65 \mathrm{mg}$ e $57 \mathrm{mg}$, nos reatores $\mathrm{R}_{\mathrm{L} 2}$ e $\mathrm{R}_{\mathrm{S} 2}$, respectivamente (Tabela 5.18).

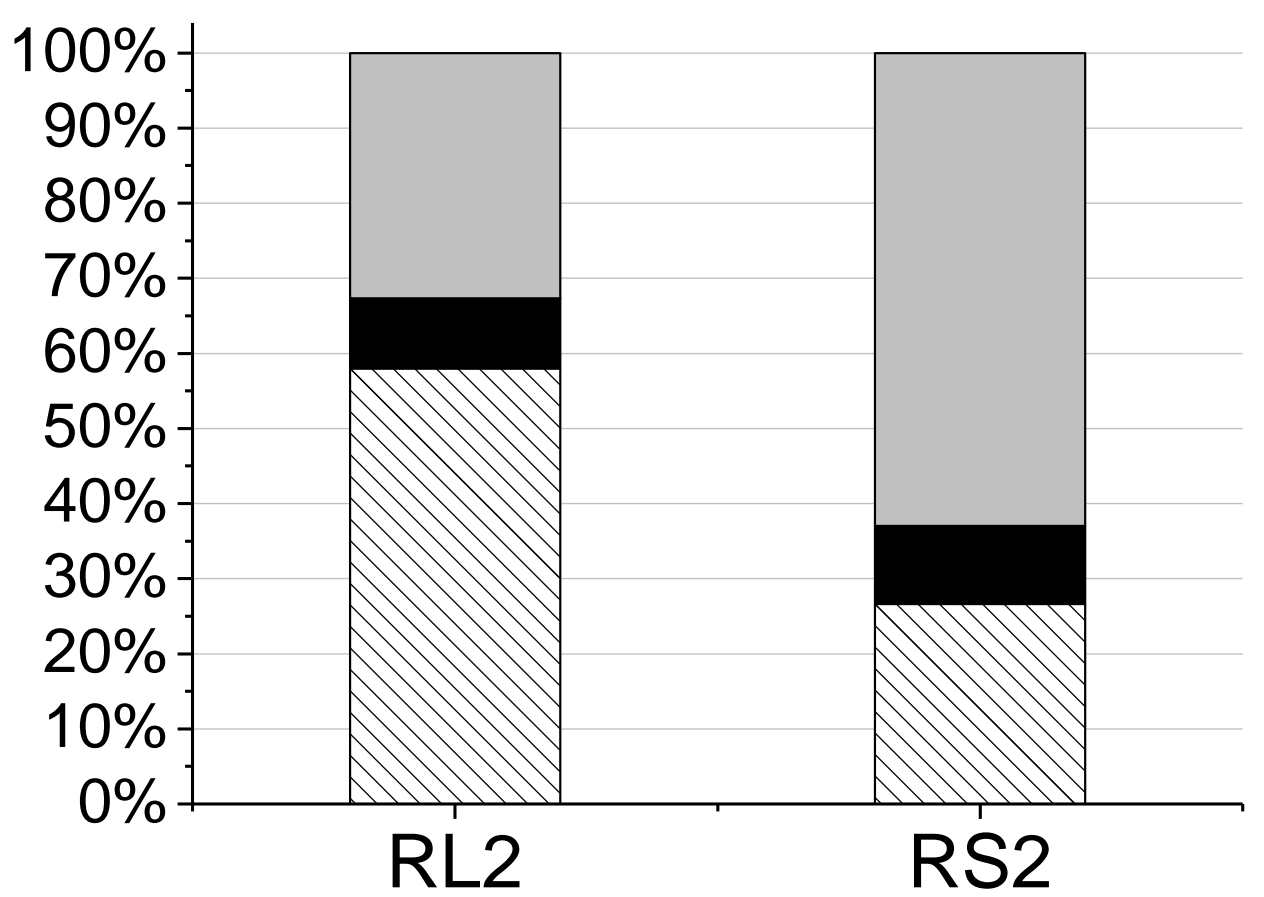

Figura 5.57: Distribuição do destino final de LAS nos reatores $\mathrm{R}_{\mathrm{L} 2}$ e $\mathrm{R}_{\mathrm{S} 2}$ : efluente $(\square)$, adsorvido na biomassa $(\square)$ e degradado $(\mathbb{Q})$ 
Tabela 5.18: Balanço de massa de LAS na Parte 2

\begin{tabular}{lrr}
\hline Balanço de massa & $\mathrm{R}_{\mathrm{L} 2}$ & \multicolumn{1}{c}{$\mathrm{R}_{\mathrm{S} 2}$} \\
\hline Adicionado (mg) & 688 & 541 \\
Adsorvido biomassa - inicial (mg) & 4 & 4 \\
Efluente (dissolvido) (mg) & 226 & 343 \\
Adsorvido (mg) & & \\
$\quad$ Manta de lodo & 44 & 27 \\
Separador de fases & 10 & 6 \\
SST efluente & 11 & 24 \\
Total Adsorvido & 65 & 57 \\
Degradado (mg) & 401 & 145 \\
Degradado (\%) & $58 \pm 16$ & $27 \pm 12$ \\
Carga específica de LAS (mg/g STV.d) & 5,3 & 5,5 \\
Degradação específica de LAS (mg/g STV.d) & 3,1 & 1,5 \\
Duração (d) & 115 & 115 \\
\hline
\end{tabular}

Observou-se que a degradação específica de LAS no reator com água residuária de lavanderia $\left(\mathrm{R}_{\mathrm{L} 2}\right)$ foi pouco maior que aquela obtida pela equação 5.1 (17\%; Figura 5.58), enquanto na Parte 1 (item 5.4.2, p. 114) observou-se variação percentual de 70\%. Atribuiu-se a menor degradação específica no reator $\mathrm{R}_{\mathrm{L} 2}$ às maiores concentrações de LAS durante o

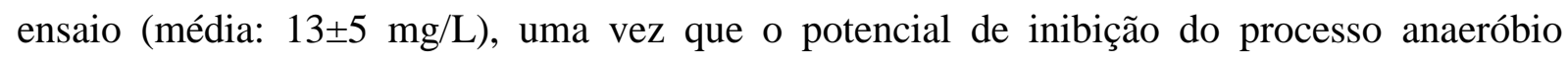
aumenta para maior concentração de surfactante (GARCIA et al., 2006b).

No reator com água residuária sintética $\left(\mathrm{R}_{\mathrm{S} 2}\right)$, observou-se degradação específica menor (cerca de 50\%) que o esperado pela equação 5.1 (Figura 5.58), devido à redução da concentração de cloreto de amônio afluente (de $1.000 \mathrm{mg} / \mathrm{L}$ para $20 \mathrm{mg} / \mathrm{L}$ ). A menor concentração de cloreto de amônio no reator $\mathrm{R}_{\mathrm{S} 2}$ resultou, consequentemente, em redução de fonte de nitrogênio, necessária para a degradação de LAS (KHLEIFAT, 2006a; ABBOUD et al., 2007). 


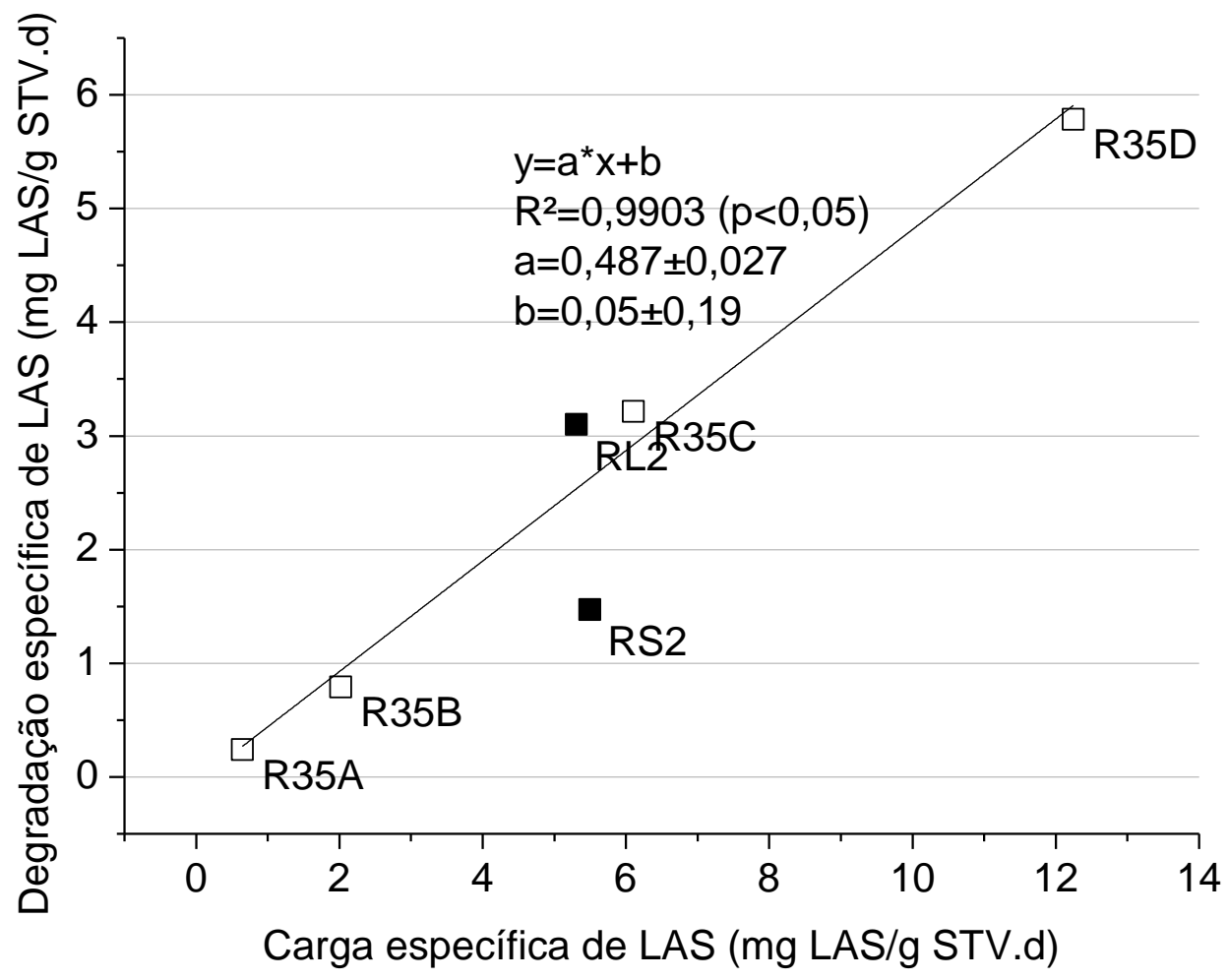

Figura 5.58: Degradação específica de LAS em função da carga específica de LAS nos

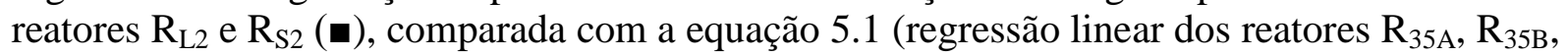
$\mathrm{R}_{35 \mathrm{C}}$ e $\mathrm{R}_{35 \mathrm{D}}$; $\square$; item 5.3)

\subsubsection{Variação espacial}

Em relação aos ácidos orgânicos voláteis, verificou-se maior consumo no reator $\mathrm{R}_{\mathrm{S} 2}$, de $37 \mathrm{mg} \mathrm{HAc/L}$, no afluente, para menos de $5 \mathrm{mg} \mathrm{HAc/L}$, a partir do ponto PA1 (Figura 5.59). No reator $R_{L 2}$, a concentração afluente de ácidos orgânicos voláteis foi baixa (5 mg HAc/L), sendo observada redução para $2 \mathrm{mg} \mathrm{HAc/L}$ no ponto PA3, seguido de aumento para 6 mg HAc/L no efluente. 


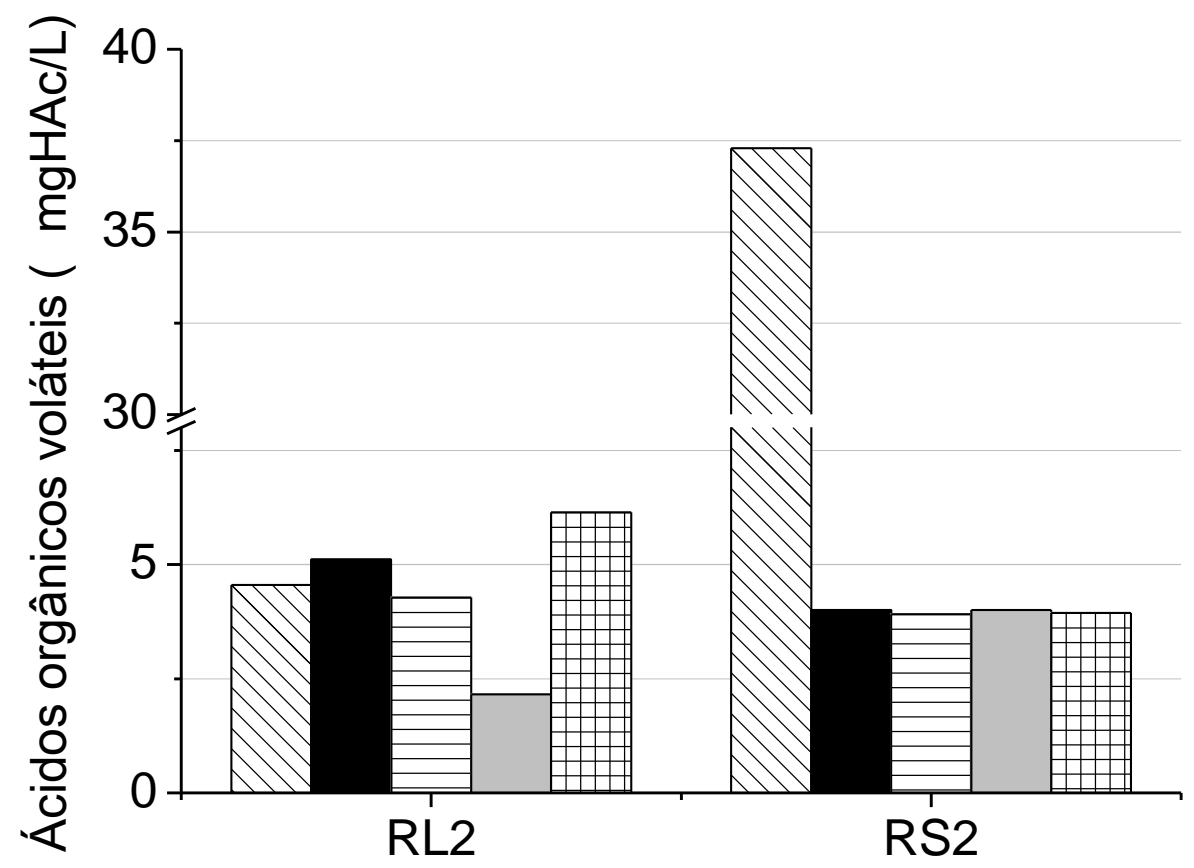

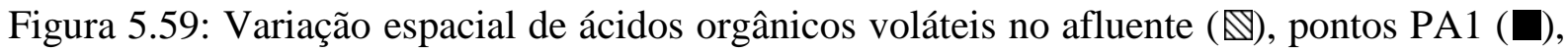
PA2 (目), PA3 ( $\square$ ) e efluente (罒), nos reatores $\mathrm{R}_{\mathrm{L} 2}$ e $\mathrm{R}_{\mathrm{S} 2}$

Observou-se remoção de LAS similar (em torno de 15\%) na manta de lodo (até o ponto PA3) e separador de fases (entre ponto PA3 e efluente) do reator $\mathrm{R}_{\mathrm{L} 2}$ (Figura 5.60). No reator $\mathrm{R}_{\mathrm{S} 2}$, verificou-se maior remoção de LAS na manta de lodo (24\%). Apesar da menor concentração de ácidos orgânicos voláteis no ponto PA3 ( $<5 \mathrm{mg} \mathrm{HAc/L})$, as eficiências de remoção de LAS no separador de fases dos reatores $R_{L 2}$ e $R_{S 2}(15$ e $11 \%$, respectivamente) foram menores que as eficiências observadas na Parte 1 (55-90\%, p. 117) e no ensaio do item $5.3(20-53 \%$, p. 88$)$. 


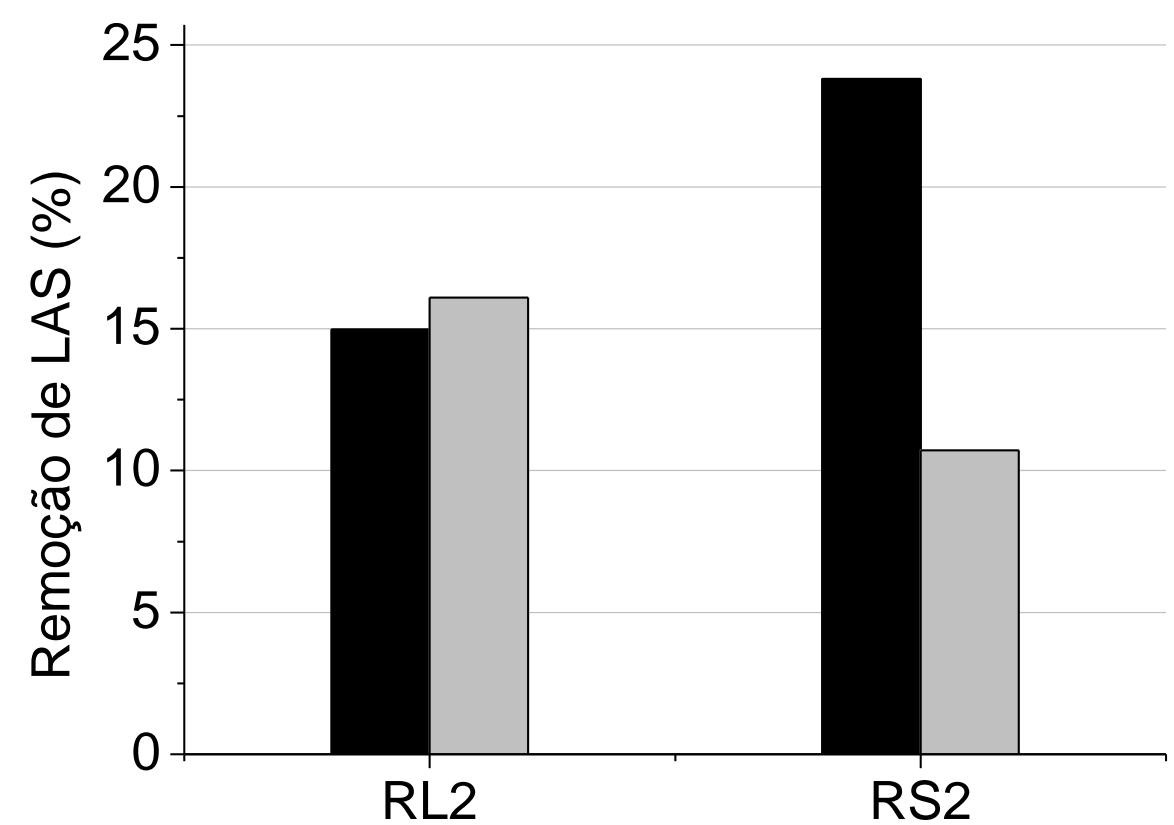

Figura 5.60: Remoção de LAS na manta de lodo ( $\square$ ) e no separador de fases ( $\square$ ), nos reatores $\mathrm{R}_{\mathrm{L} 2}$ e $\mathrm{R}_{\mathrm{S} 2}$

\subsubsection{Pirosequenciamento de amostras da Parte 1}

O pirosequenciamento das amostras do ensaio de degradação de LAS em água residuária de lavanderia resultou em total de 35.381 sequências (somando as quatro amostras - sendo duas da manta de lodo e duas do separador de fases dos reatores $\mathrm{R}_{\mathrm{L} 1}$ e $\mathrm{R}_{\mathrm{S} 1}$ ). Desse total, foram selecionadas 26.393 sequências, com 215-322 pb (média: $287 \pm 13$ pb). No histograma de distribuição do comprimento das sequências, observou-se que a maior parte das sequências possuía entre 280 e 290 pb (Figura 5.61). 


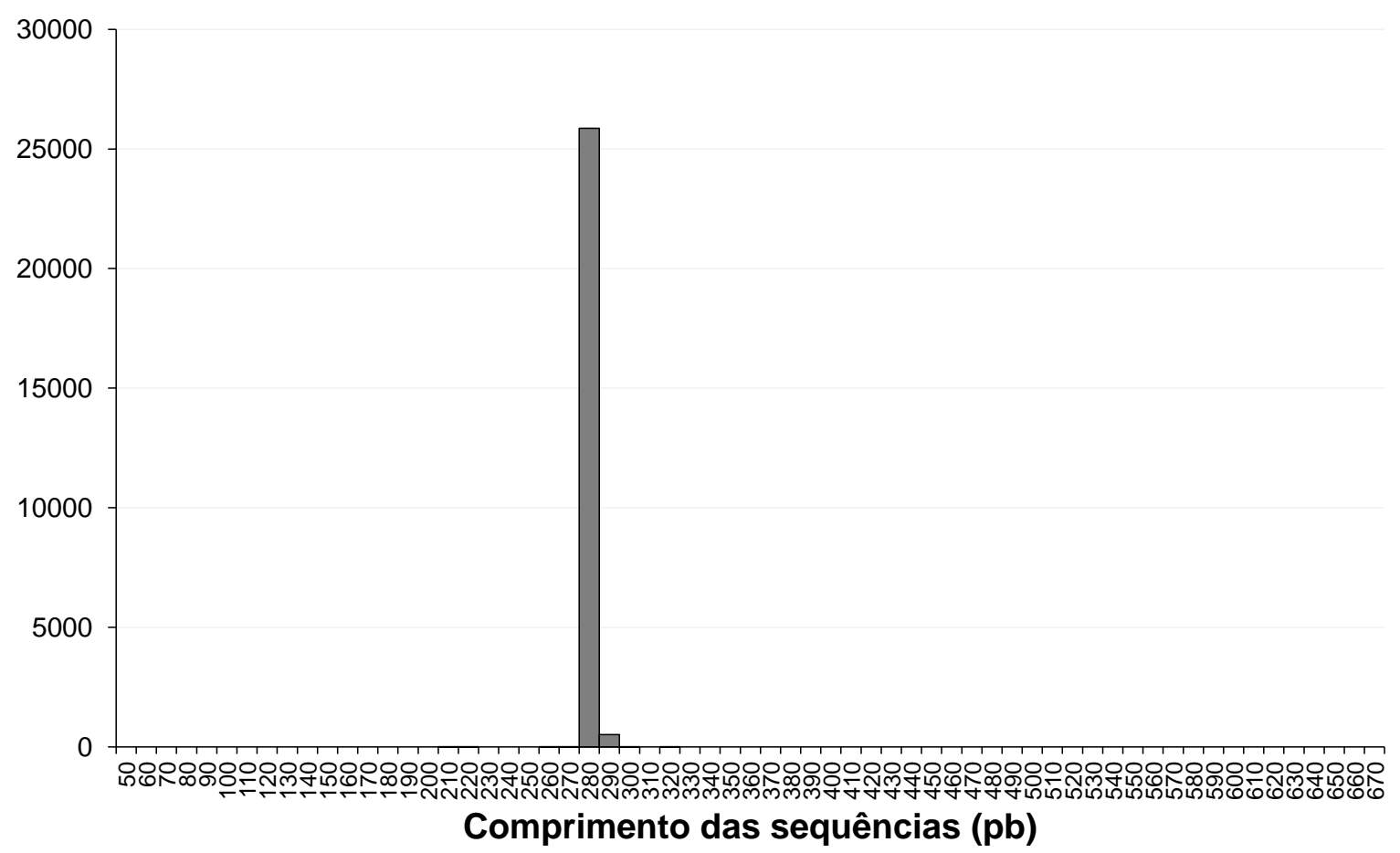

Figura 5.61: Histograma da distribuição do comprimento das sequências

Dentre as sequências selecionadas, cerca de 5.600 a 8.100 foram atribuídas para cada amostra (Tabela 5.19). Ao todo foram definidas 937 UTOs, sendo cerca de 400 das UTOs atribuídas às amostras da manta de lodo dos reatores $\mathrm{R}_{\mathrm{L} 1}$ e $\mathrm{R}_{\mathrm{S} 1}$, e cerca de 300 das UTOs atribuídas às amostras da biomassa do separador de fases dos dois reatores.

Tabela 5.19: Quantidade de sequências e UTOs atribuídas para cada amostra

\begin{tabular}{lcc}
\hline Amostra & Sequências & $\begin{array}{c}\text { UTOs } \\
\text { (Similaridade 97\%) }\end{array}$ \\
\hline Manta de lodo-Reator $\mathrm{R}_{\mathrm{L} 1}\left(\mathrm{ML}-\mathrm{R}_{\mathrm{L} 1}\right)$ & 6.491 & 445 \\
Separador de fases-Reator $\mathrm{R}_{\mathrm{L} 1}\left(\mathrm{SF}-\mathrm{R}_{\mathrm{L} 1}\right)$ & 5.580 & 259 \\
Manta de lodo-Reator $\mathrm{R}_{\mathrm{S} 1}\left(\mathrm{ML}-\mathrm{R}_{\mathrm{S} 1}\right)$ & 8.118 & 412 \\
Separador de fases-Reator $\mathrm{R}_{\mathrm{S} 1}\left(\mathrm{SF}-\mathrm{R}_{\mathrm{S} 1}\right)$ & 6.204 & 307 \\
Total & 26.393 & 937 \\
\hline
\end{tabular}




\subsubsection{1 Índices de diversidade}

Observou-se pouca variação do índice de equitabilidade, com valores entre 0,57 e 0,68 (Tabela 5.20). Portanto, verificou-se significativa variação na distribuição da comunidade microbiana, uma vez que valores próximos de 1 indicam altas variações.

Tabela 5.20: Índices de diversidade determinados no nível de $97 \%$ de similaridade, nas amostras dos reatores $\mathrm{R}_{\mathrm{L} 1}$ e $\mathrm{R}_{\mathrm{S} 1}$

\begin{tabular}{lcccc}
\hline Filo & ML-R $_{\mathrm{L} 1}$ & SF-R $_{\mathrm{L} 1}$ & ML-R $_{\mathrm{S} 1}$ & SF-R $_{\mathrm{S} 1}$ \\
\hline Dominância & 0,07 & 0,096 & 0,114 & 0,101 \\
Equitabilidade & 0,676 & 0,609 & 0,568 & 0,65 \\
Shannon & $4,56 \pm 0,02$ & $3,67 \pm 0,03$ & $3,99 \pm 0,02$ & $3,99 \pm 0,03$ \\
UTOs simples & 165 & 94 & 175 & 113 \\
& $(37,1 \%)$ & $(36,3 \%)$ & $(42,5 \%)$ & $(36,8 \%)$ \\
UTOs duplas & 64 & 39 & 61 & 50 \\
& $(14,4 \%)$ & $(15,1 \%)$ & $(14,8 \%)$ & $(16,3 \%)$ \\
\hline
\end{tabular}

Com relação ao índice de dominância, foram observados valores baixos, entre 0,07 e 0,11 (Tabela 5.20), portanto, distribuição mais equânime dos táxons na comunidade microbiana em cada amostra (valores próximos de 0 indicam a presença equânime de todos táxons, enquanto, valores próximo de 1 indicam o domínio de um táxon na comunidade microbiana).

Observou-se pouca variação do índice de Shannon, entre 4,9 e 6,0 (Tabela 5.20), indicando, portanto, significativa riqueza das amostras (quanto maior o índice, maior o $\mathrm{n}^{\mathrm{o}} \mathrm{de}$ táxons na comunidade microbiana). O maior índice de Shannon foi aquele obtido para amostra da manta de lodo do reator com água residuária de lavanderia $\left(\mathrm{R}_{\mathrm{L} 1}: 6,0\right)$, seguida pela amostra da biomassa do separador de fases do reator com água residuária sintética $\left(\mathrm{R}_{\mathrm{S} 1}: 5,4\right)$, sendo as demais amostras com índice em torno de 4,9.

Apesar do índice de Shannon indicar maior riqueza nas amostras da manta de lodo do reator $\mathrm{R}_{\mathrm{L} 1}$ e da biomassa do separador de fase do reator do reator $\mathrm{R}_{\mathrm{S} 1}$, não se observou o 
mesmo para os índices de rarefação e Chao1. Por meio de análise dos estimadores de rarefação e Chao1 observou-se maior riqueza nas amostras da manta de lodo dos reatores $R_{\mathrm{L} 1}$ $\left(M L-R_{L 1}\right)$ e $R_{S 1}\left(M L-R_{S 1}\right)$ que nas amostras da biomassa do separador de fases $\left(S F-R_{L 1}\right.$ e $S F-$ $\mathrm{R}_{\mathrm{S} 1}$ ) (Tabela 5.21). Para 97\% de similaridade observou-se estimador de rarefação em torno de 410-440, e de Chao1 em torno de 650-660, nas amostras da manta de lodo. Nas amostras da biomassa do separador de fases, no mesmo nível de similaridade (97\%), foram observados estimadores de rarefação e de Chao1, em torno de 260-310 e 370-430, respectivamente. Atribuiu-se o menor índice de Shannon da amostra da manta de lodo do reator $\mathrm{R}_{\mathrm{S} 1}(4,9)$ à maior parcela de UTOs únicas (com apenas uma sequência); ou seja, 43\% na manta de lodo do reator $R_{S 1}$, enquanto, foram observados valores em torno de $37 \%$ nas demais amostras (Tabela 5.20). A maior parcela de UTOs únicas resultou em menor índice de Shannon, uma vez que o índice considera a quantidade e abundância relativa de cada UTO (o índice de Shannon é definido pela equação $\mathrm{H}^{\prime}=-\Sigma p_{i} \ln p_{i}$; sendo $p_{i}$ a abundância relativa de cada UTO). Observou-se pouca variação, entre 14 e 16\%, para UTOs duplas, indicando pouca influência desse parâmetro nos índices de Shannon. 
Tabela 5.21: Comparação entre estimadores de riqueza

\begin{tabular}{lcc}
\hline & Rarefação & Chao1 \\
\hline Similaridade 97\% & 445 & $653 \pm 63$ \\
Manta de lodo-Reator $\mathrm{R}_{\mathrm{L} 1}\left(\mathrm{ML}-\mathrm{R}_{\mathrm{L} 1}\right)$ & 259 & $368 \pm 45$ \\
Separador de fases-Reator $\mathrm{R}_{\mathrm{L} 1}\left(\mathrm{SF}-\mathrm{R}_{\mathrm{L} 1}\right)$ & 412 & $658 \pm 73$ \\
Manta de lodo-Reator $\mathrm{R}_{\mathrm{S} 1}\left(\mathrm{ML}-\mathrm{R}_{\mathrm{S} 1}\right)$ & 307 & $431 \pm 45$ \\
Separador de fases-Reator $\mathrm{R}_{\mathrm{S} 1}\left(\mathrm{SF}-\mathrm{R}_{\mathrm{S} 1}\right)$ & & \\
Similaridade 95\% & 322 & $463 \pm 75$ \\
Manta de lodo-Reator $\mathrm{R}_{\mathrm{L} 1}\left(\mathrm{ML}-\mathrm{R}_{\mathrm{L} 1}\right)$ & 194 & $261 \pm 48$ \\
Separador de fases-Reator $\mathrm{R}_{\mathrm{L} 1}\left(\mathrm{SF}-\mathrm{R}_{\mathrm{L} 1}\right)$ & 307 & $453 \pm 76$ \\
Manta de lodo-Reator $\mathrm{R}_{\mathrm{S} 1}\left(\mathrm{ML}-\mathrm{R}_{\mathrm{S} 1}\right)$ & 215 & $290 \pm 50$ \\
Separador de fases-Reator $\mathrm{R}_{\mathrm{S} 1}\left(\mathrm{SF}-\mathrm{R}_{\mathrm{S} 1}\right)$ & & \\
Similaridade 90\% & 208 & $290 \pm 61$ \\
Manta de lodo-Reator $\mathrm{R}_{\mathrm{L} 1}\left(\mathrm{ML}-\mathrm{R}_{\mathrm{L} 1}\right)$ & 133 & $163 \pm 30$ \\
Separador de fases-Reator $\mathrm{R}_{\mathrm{L} 1}\left(\mathrm{SF}-\mathrm{R}_{\mathrm{L} 1}\right)$ & 195 & $246 \pm 39$ \\
Manta de lodo-Reator $\mathrm{R}_{\mathrm{S} 1}\left(\mathrm{ML}-\mathrm{R}_{\mathrm{S} 1}\right)$ & 140 & $168 \pm 28$ \\
Separador de fases-Reator $\mathrm{R}_{\mathrm{S} 1}\left(\mathrm{SF}-\mathrm{R}_{\mathrm{S} 1}\right)$ &
\end{tabular}

Por meio da análise das curvas de rarefação evidenciou-se maior riqueza para amostra da manta de lodo do reator com água residuária de lavanderia $\left(\mathrm{R}_{\mathrm{L} 1}\right)$ (Figura 5.62). A diferença de riqueza entre a amostra da manta de lodo do reator $\mathrm{R}_{\mathrm{L} 1}$ e as demais amostras diminuiu conforme a redução do nível de similaridade, de 97 para 80\%. Atribuiu-se a maior riqueza da amostra da manta de lodo do reator $\mathrm{R}_{\mathrm{L} 1}$ às condições de alimentação que, conforme observado na caracterização da água residuária de lavanderia (item 5.4.1; p. 105), propiciaram diversos co-substratos favoráveis à manutenção e crescimento de populações diversas de bactérias. Além disso, a estrutura granulada protegeu algumas populações microbianas dos reatores $\mathrm{R}_{\mathrm{L} 1}$ e $\mathrm{R}_{\mathrm{S} 1}$, assegurando a maior riqueza observada para as duas amostras, corroborando o observado no presente estudo mediante análise de FISH (item 5.2.3, p. 63) e por meio da técnica de PCR-DGGE (item 5.3.6; p. 91). 


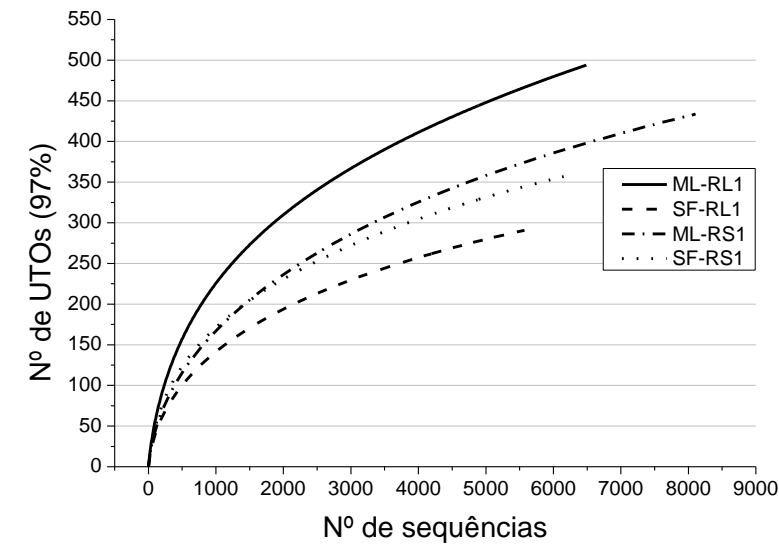

(a)

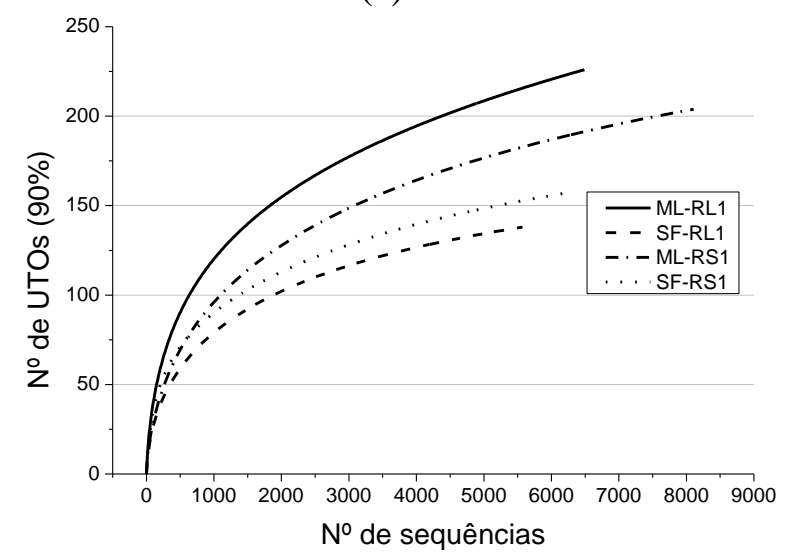

(c)

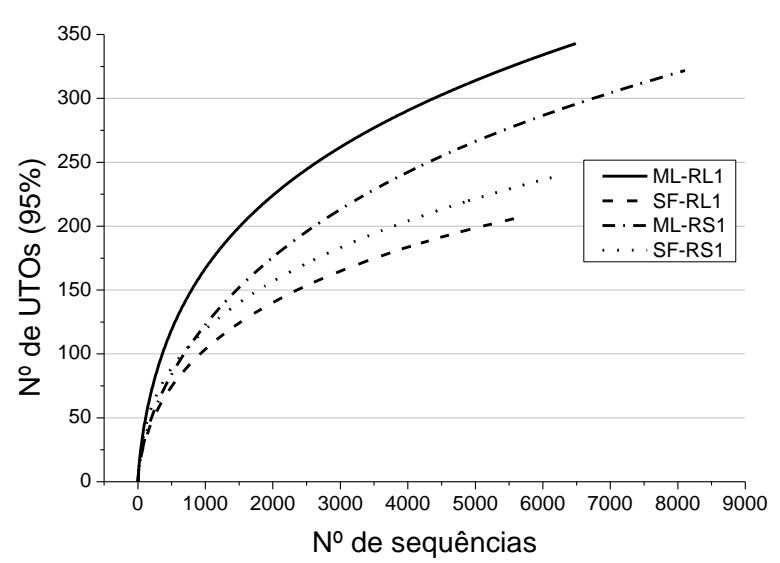

(b)

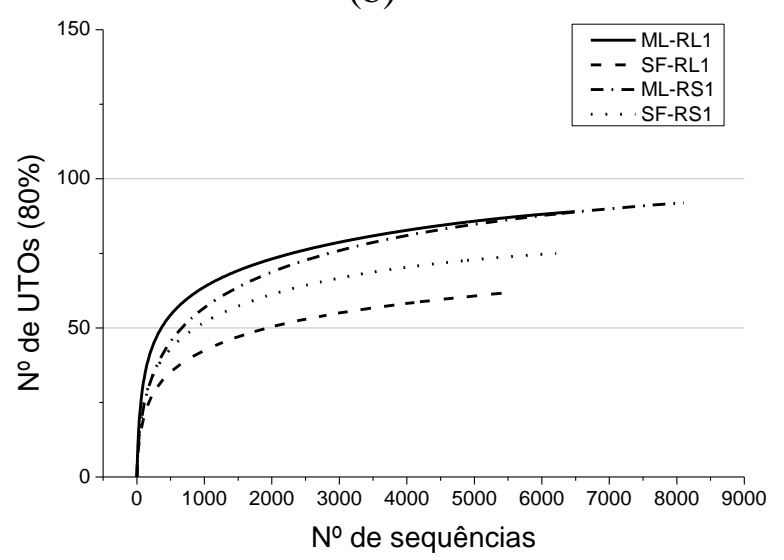

(d)

Figura 5.62: Curva de rarefação definida para similaridade de 97\% (a), 95\% (b), 90\% (c) e $80 \%$ (d), das sequências de amostras da manta de lodo (ML-RL1) e biomassa do separador de fases (SF-RL1) do reator $\mathrm{R}_{\mathrm{L} 1}$, e da manta de lodo (ML-RS1) e biomassa do separador de fases (SF-RS1) do reator $\mathrm{R}_{\mathrm{S} 1}$

Devido às condições da biomassa na manta de lodo, observou-se maior coeficiente de similaridade entre as amostras dessa região nos reatores $R_{\mathrm{L} 1}$ e $\mathrm{R}_{\mathrm{S} 1}$ de acordo com os índices de diversidade beta (Figura 5.63). Os coeficientes de similaridades obtidos para essas amostras da manta de lodo foram de $74 \%$ a $88 \%$. Todavia, para as amostras da biomassa do separador de fases observou-se variação de $57 \%$ a $82 \%$.

Em relação aos índices de Bray-Curtis e UniFrac não ponderado, observou-se pouca diferença entre as amostras da manta de lodo (74-75\%). O índice UniFrac analisa a distância evolutiva entre as populações microbianas, enquanto, o índice de Bray-Curtis considera riqueza e uniformidade, porém cada UTO é distinta na comparação entre amostras, independente da distância evolutiva. Dessa forma, a similaridade entre as amostras da manta 
de lodo foi, principalmente, devido à riqueza e semelhança de UTOs atribuídas em cada amostra.

Em relação às amostras da biomassa do separador de fases observou-se aumento significativo da similaridade obtida pelos índices de Bray-Curtis e UniFrac não ponderado (de $57 \%$ para $70 \%$ ), portanto, maior similaridade entre as amostras ao se considerar a distância evolutiva das comunidades microbianas. Entre os índices UniFrac não ponderado e UniFrac ponderado observou-se aumento do coeficiente de similaridade de $12-14 \%$ entre as amostras da manta de lodo e da biomassa do separador de fases. Observou-se índice UniFrac ponderado de 88 e $82 \%$, entre as amostras da manta de lodo e biomassa do separador de fases, respectivamente. O índice UniFrac ponderado considera a abundância relativa das UTOs, indicando que a distribuição dos táxons teve peso semelhante nos coeficientes de similaridade entre as amostras da manta de lodo e da biomassa do separador de fases. 

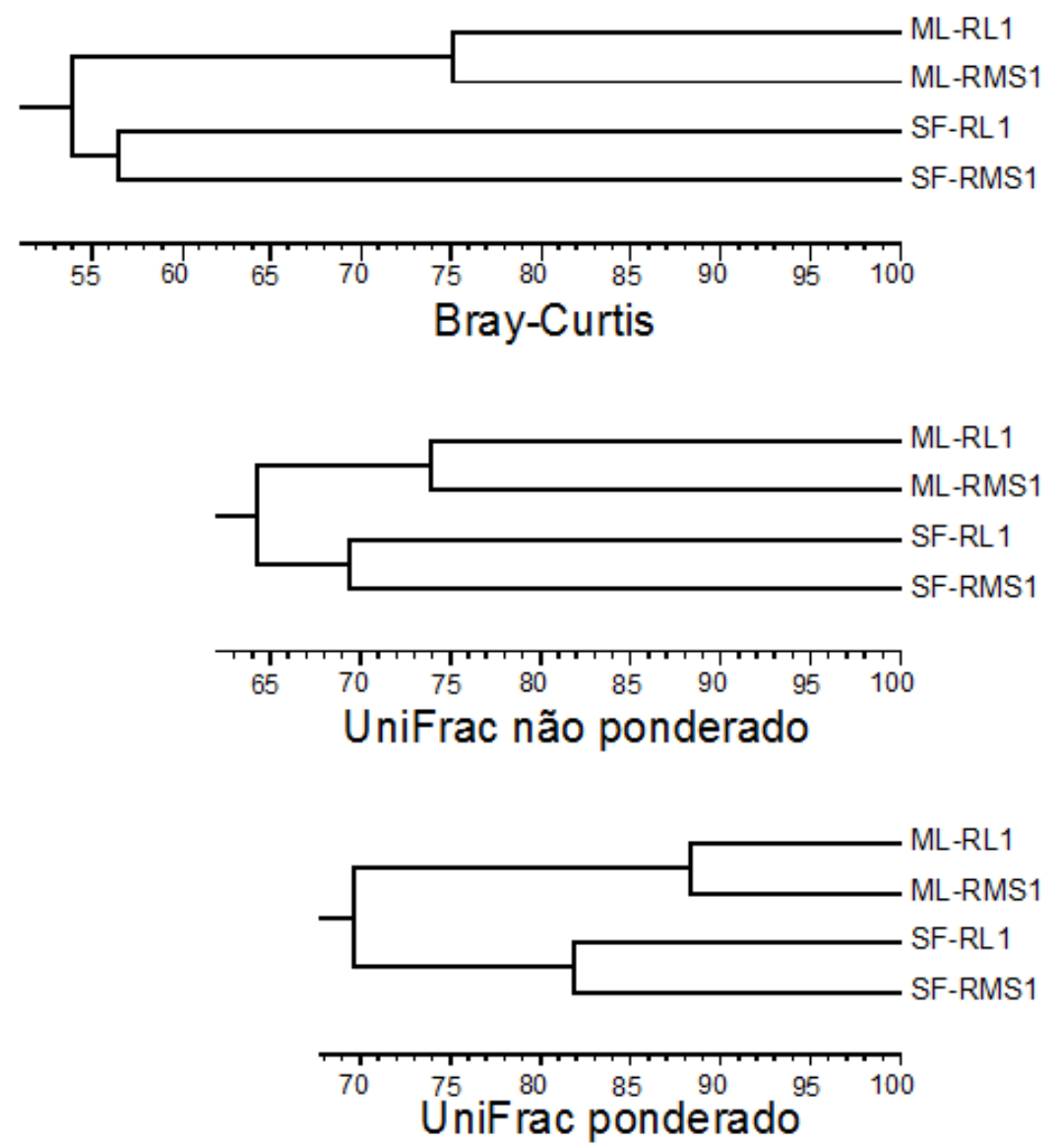

Figura 5.63: Dendrogramas baseados nos índices de Bray-Curtis, UniFrac não ponderado e UniFrac ponderado para as amostras da manta de lodo (ML-RL1) e biomassa do separador de fases (SF-RL1) do reator $\mathrm{R}_{\mathrm{L} 1}$, e da manta de lodo (ML-RS1) e biomassa do separador de fases (SF-RS1) do reator $\mathrm{R}_{\mathrm{S} 1}$, para similaridade de $97 \%$

Atribuiu-se a menor riqueza das amostras da biomassa do separador de fases à maior exposição das populações microbianas às condições do ensaio, corroborando a maior variação dos coeficiente de similaridade observados mediante técnica de PCR-DGGE aplicada no presente estudo (item 5.3.6, p. 91).

Com relação à uniformidade das amostras, observou-se variação significativa na distribuição dos táxons, não ocorrendo predominância de apenas um táxon, conforme observado pelos índices de equitabilidade e dominância. Observou-se maior riqueza e similaridade para as amostras da manta de lodo. Destacou-se também a maior riqueza da amostra da manta de lodo do reator $\mathrm{R}_{\mathrm{L} 1}$, atribuída à diversidade de co-substratos fornecida na água residuária de lavanderia. Em virtude da maior exposição às condições do experimento 
observou-se menor riqueza e menor coeficiente de similaridade (segundo os índices de diversidade beta supracitados) entre as amostras da biomassa do separador de fases. Apesar do menor coeficiente de similaridade entre as amostras da biomassa do separador de fases, observou-se aumento significativo da similaridade ao se considerar a distância evolutiva das UTOs.

\subsubsection{Caracterização da diversidade microbiana}

Por meio da aplicação do RDP-Classifier obteve-se classificação em filos do domínio Bacteria de $77 \%$ a $88 \%$ das UTOs para cada amostra, correpondendo a abundância relativa entre 72 e 95\% (Tabela 5.22). Verificou-se menor parcela de UTOs classificadas em classe (67-82\%), ordem (61-78\%), família (46-68\%) e gênero (32-53\%).

Tabela 5.22: Porcentagem de UTOs (similaridade 97\%) e sequências classificadas taxonomicamente em cada amostra

\begin{tabular}{|c|c|c|c|c|c|c|c|c|}
\hline & \multicolumn{2}{|c|}{$\operatorname{ML} \mathrm{R}_{\mathrm{L} 1}(\%)$} & \multicolumn{2}{|c|}{ SF-R $\mathrm{L}_{1}(\%)$} & \multicolumn{2}{|c|}{$\operatorname{ML}-R_{\mathrm{S} 1}(\%)$} & \multicolumn{2}{|c|}{$\mathrm{SF} \mathrm{R}_{\mathrm{S} 1}(\%)$} \\
\hline & UTO & $\begin{array}{c}\text { Abundância } \\
\text { relativa }\end{array}$ & UTO & $\begin{array}{c}\text { Abundância } \\
\text { relativa }\end{array}$ & UTO & $\begin{array}{c}\text { Abundância } \\
\text { relativa }\end{array}$ & UTO & $\begin{array}{c}\text { Abundância } \\
\text { relativa }\end{array}$ \\
\hline Filo & 78,7 & 79,4 & 86,5 & 94,1 & 76,7 & 71,7 & 87,6 & 94,6 \\
\hline Classe & 70,1 & 76,4 & 80,3 & 89,5 & 66,7 & 69,6 & 82,1 & 93,2 \\
\hline Ordem & 63,8 & 75,1 & 71,4 & 61,6 & 60,7 & 68,8 & 78,2 & 92,2 \\
\hline Família & 49,7 & 46,1 & 64,1 & 60,1 & 46,1 & 31,5 & 68,1 & 83,0 \\
\hline Gênero & 33,3 & 36,1 & 45,9 & 45,2 & 31,6 & 28,1 & 52,8 & 77,1 \\
\hline
\end{tabular}

ML: manta de lodo

SF: biomassa do separador de fases

Observou-se abundância relativa de gêneros classificados em torno de $28-46 \%$, com exceção da amostra da biomassa do separador de fases do reator $\mathrm{R}_{\mathrm{S} 1}(77 \%$ de abundância relativa). Ao todo, foram identificados 147 gêneros, compreendendo 348 UTOs, ou seja, 589 UTOs não foram classificadas com relação a gênero (63\%). Apesar da maior riqueza verificada nas amostras da manta de lodo, segundo os índices de diversidade no item anterior, 
foram observados menos gêneros classificados na manta de lodo do reator $R_{\mathrm{S} 1}$ (73) que na biomassa do separador de fases (85) (Tabela 5.23). Além disso, observou-se menor quantidade de gêneros classificados nas amostras do reator $R_{\mathrm{L} 1}$ (64 na manta de lodo e 63 na biomassa do separador de fases).

Tabela 5.23: Quantidade de gêneros classificados em cada amostra (similaridade 97\%)

\begin{tabular}{lc}
\hline Amostra & Gêneros \\
\hline Manta de lodo-Reator $\mathrm{R}_{\mathrm{L} 1}\left(\mathrm{ML}-\mathrm{R}_{\mathrm{L} 1}\right)$ & 64 \\
Separador de fases-Reator $\mathrm{R}_{\mathrm{L} 1}\left(\mathrm{SF}-\mathrm{R}_{\mathrm{L} 1}\right)$ & 63 \\
Manta de lodo-Reator $\mathrm{R}_{\mathrm{S} 1}\left(\mathrm{ML}-\mathrm{R}_{\mathrm{S} 1}\right)$ & 73 \\
Separador de fases-Reator $\mathrm{R}_{\mathrm{S} 1}\left(\mathrm{SF}-\mathrm{R}_{\mathrm{S} 1}\right)$ & 85 \\
\hline
\end{tabular}

Em virtude da limitada representatividade dos gêneros classificados, a caracterização da comunidade microbiana ateve-se à descrição dos gêneros classificados em cada amostra, evitando-se a comparação entre amostras. Devido à quantidade de gêneros classificados (6385), restringiu-se à descrição dos 20 gêneros com maior abundância relativa em cada amostra. Em seguida, foram listados os gêneros relacionados com a degradação de LAS, ou seja, especificamente aqueles relacionados com a degradação de compostos aromáticos com um anel (fenol, tolueno, benzaldeído, metoxi-, hidroxi- e benzoatos), reações de dessulfonação, $\beta$ e $\omega$-oxidação. Nesse caso realizou-se a comparação entre as amostras, uma vez que a análise se restringia aos gêneros relacionados com a degradação de LAS. Em virtude da abundância relativa dos filos classificados (entre 72 e 95\%), foram descritos e comparados os filos observados nas amostras dos reatores $\mathrm{R}_{\mathrm{L} 1}$ e $\mathrm{R}_{\mathrm{S} 1}$.

\subsection{Filos}

Com relação aos filos observados na manta de lodo dos reatores $\mathrm{R}_{\mathrm{L} 1}$ e $\mathrm{R}_{\mathrm{S} 1}$, destacou-se a presença dos seguintes: Firmicutes (33-41\%), Proteobacteria (6-20\%), Chloroflexi (7-14\%) e Synergistetes (5-12\%) (Figura 5.64). Observou-se maior abundância relativa dos filos 
Firmicutes, Proteobacteria e Chloroflexi na amostra do reator $\mathrm{R}_{\mathrm{L} 1}$ (14-33\%), e maior abundância relativa dos filos Firmicutes e Synergistetes na amostra do reator $\mathrm{R}_{\mathrm{S} 1}(12-41 \%)$.

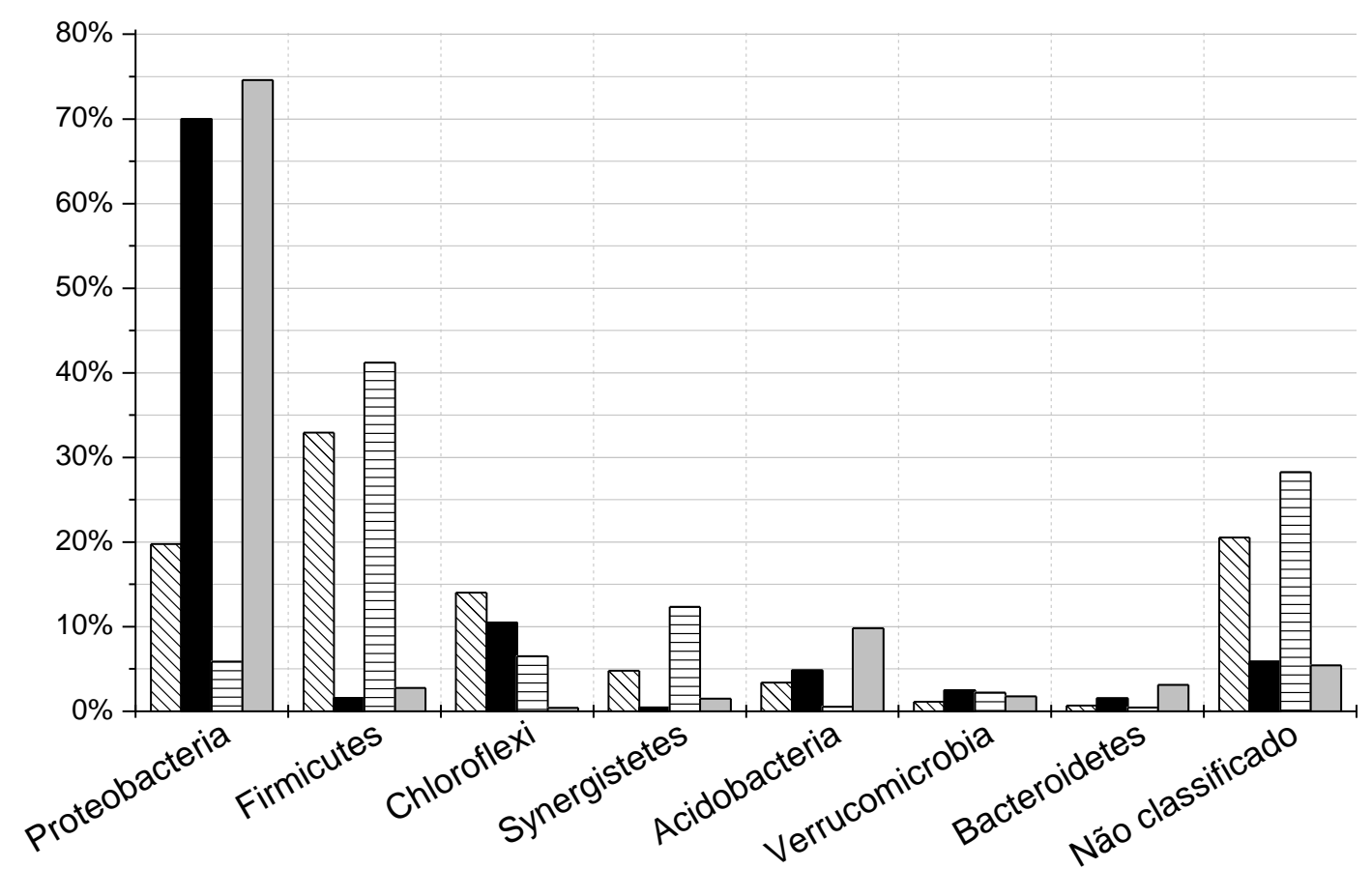

Figura 5.64: Abundância relativa de filo (similaridade 97\%) nas amostras da manta de lodo ( $\mathbb{\mathbb { }}$ ) e biomassa do separador de fases $(\boldsymbol{\square})$ do reator $\mathrm{R}_{\mathrm{L} 1}$, e da manta de lodo (目) e biomassa do separador de fases $(\square)$ do reator $\mathrm{R}_{\mathrm{S} 1}$

$\mathrm{Na}$ biomassa do separador de fases dos reatores $R_{L 1}$ e $R_{S 1}$, verificou-se, principalmente, a presença do filo Proteobacteria (70-74\%). Além desse filo, observou-se também que $10 \%$ da abundância relativa da biomassa do separador de fases do reator $\mathrm{R}_{\mathrm{L} 1}$ foi relacionada ao filo Chloroflexi. Essa mesma abundância relativa foi observada para o filo Acidobacteria, todavia, na amostra da biomassa do separador de fases do reator $\mathrm{R}_{\mathrm{S} 1}$. Observou-se maior diferença da abundância relativa para representantes do filo Proteobacteria (70-74\%), em relação aos demais filos classificados (abaixo de 10\%) para as amostras do separador de fases dos dois reatores $\left(\mathrm{R}_{\mathrm{L} 1}\right.$ e $\left.\mathrm{R}_{\mathrm{S} 1}\right)$. 
A parcela de filos não classificados foi maior (21 e 28\%) na manta de lodo dos dois reatores e menor (6\%) na biomassa do separador de fases. Ao todo, foram classificados 21 filos, conforme listados na Tabela 5.24.

Tabela 5.24: Abundância relativa de filo (similaridade 97\%)

\begin{tabular}{lcccc}
\hline Filo & ML-R $_{\mathrm{L} 1}(\%)$ & SF-R $_{\mathrm{L} 1}(\%)$ & ML-R $_{\mathrm{S} 1}(\%)$ & SF-R $_{\mathrm{S} 1}(\%)$ \\
\hline Acidobacteria & 3,39 & 4,82 & 0,55 & 9,83 \\
Actinobacteria & 0,42 & 0,02 & 0,23 & 0,06 \\
Bacteroidetes & 0,66 & 1,52 & 0,44 & 3,11 \\
BRC1 & 0,15 & 0,05 & 0,12 & - \\
Chlamydiae & 0,40 & 0,07 & 0,17 & 0,02 \\
Chloroflexi & 14,03 & 10,48 & 6,52 & 0,42 \\
Cyanobacteria & - & 0,02 & - & - \\
Deferribacteres & - & - & 0,01 & - \\
Euryarchaeota & 0,49 & 0,02 & 0,26 & 0,03 \\
Firmicutes & 32,95 & 1,58 & 41,23 & 2,77 \\
Fusobacteria & - & - & 0,01 & - \\
Gemmatimonadetes & - & 1,31 & - & 0,23 \\
Lentisphaerae & 0,03 & 0,04 & - & 0,15 \\
OD1 & 0,08 & - & 0,06 & - \\
Planctomycetes & 0,17 & 0,02 & 0,09 & 0,02 \\
Proteobacteria & 19,78 & 69,98 & 5,86 & 74,60 \\
Spirochaetes & 0,03 & 1,25 & 0,06 & 0,05 \\
Synergistetes & 4,78 & 0,43 & 12,33 & 1,50 \\
Thermotogae & 0,96 & 0,02 & 1,55 & - \\
Verrucomicrobia & 1,12 & 2,47 & 2,22 & 1,77 \\
WS3 & - & 0,02 & 0,01 & - \\
Não classificado & 20,55 & 5,88 & 28,26 & 5,45 \\
\hline
\end{tabular}

\subsection{Gêneros na amostra da manta de lodo do reator $R_{L 1}$}

Para os 20 gêneros com maior abundância relativa obtidos da manta de lodo do reator $\mathrm{R}_{\mathrm{L} 1}$, foram observados valores entre 0,4 e 5,7\% (Figura 5.65). Dentre esses 20 gêneros, 15 foram relacionados com representantes de ambiente anaeróbio ou anaeróbio estrito (Tabela 5.25). Os outros cinco gêneros foram relacionados com bactérias aeróbias, apesar da existência de algumas capazes de se manterem em condição anaeróbia, tais como: Bosea, Brevundimonas, Pseudomonas e Zoogloea (OUATTARA et al., 2003; BRENNER et al., 
2005; KANG et al., 2009). Algumas espécies de Pseudomonas e Zoogloea podem usar nitrato, em substituição ao oxigênio, como aceptor final de elétrons, permitindo seu desenvolvimento em condição anóxica (BRENNER et al., 2005). O uso de nitrato como aceptor final de elétrons é uma possibilidade, considerando sua presença na água residuária de lavanderia (concentração estimada em torno de $0,02 \mathrm{mg}$ N/L, com base na caracterização da água de lavanderia e nas diluições usadas no reator $\mathrm{R}_{\mathrm{L1}}$; item 5.4.1.1, p. 104). Outra possibilidade seria a presença de oxigênio em pequenas quantidades, uma vez que não se verificou coloração rosa na região da manta de lodo após adição de resazurina (item 5.4.2, p. 111). Hirasawa et al. (2008) verificaram a coexistência de comunidades microbianas anaeróbias na presença de oxigênio em reator UASB inoculado com lodo granulado, sendo, portanto, possível a presença de gêneros aeróbios e anaeróbios na manta de lodo.

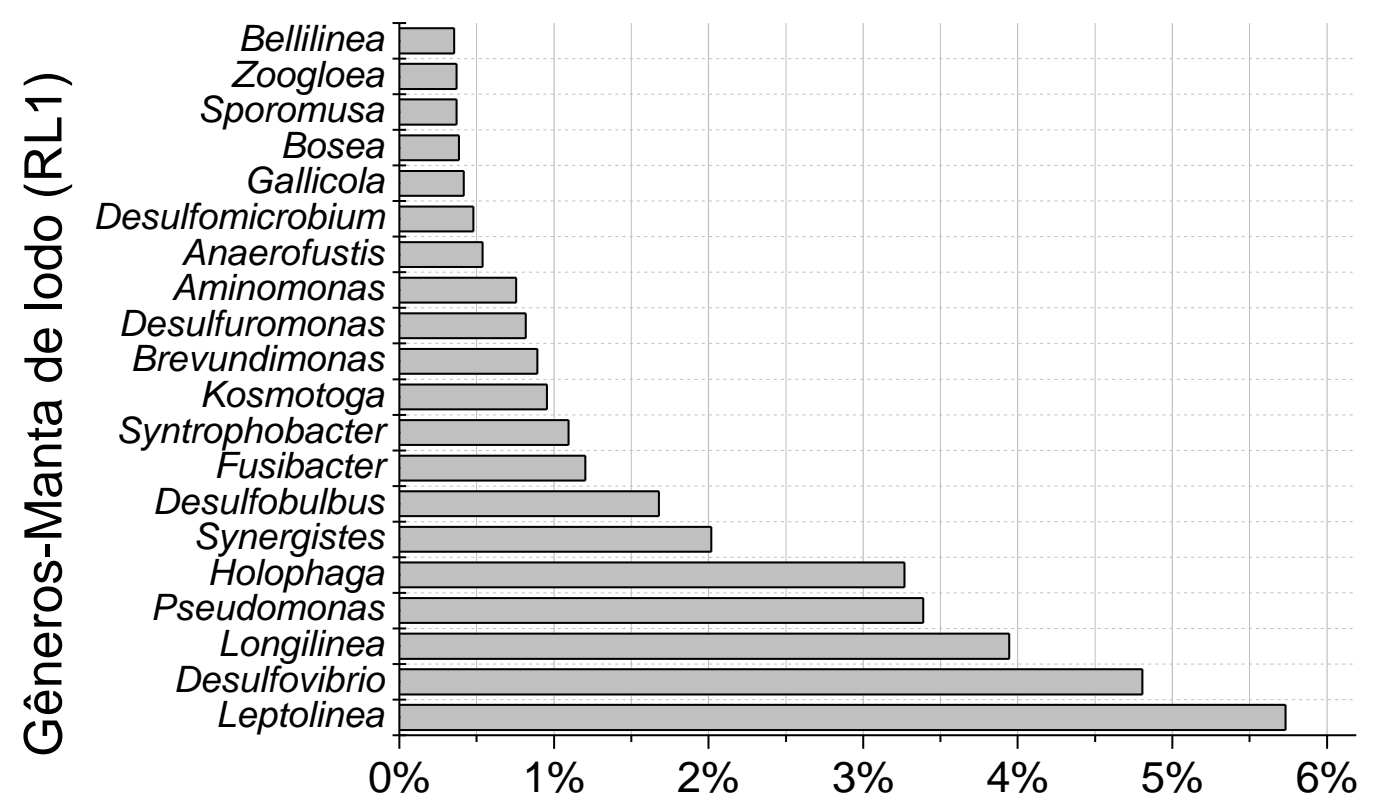

Figura 5.65: Abundância relativa dos 20 gêneros mais frequentes na amostra da manta de lodo do reator $\mathrm{R}_{\mathrm{L} 1}$ (similaridade $97 \%$ ) 
Tabela 5.25: Descrição dos 20 gêneros de maior abundância relativa na amostra da manta de lodo do reator $\mathrm{R}_{\mathrm{L} 1}$ (similaridade $97 \%$ )

\begin{tabular}{|c|c|c|c|}
\hline Gênero & Gram & Condição & Referência \\
\hline Aminomonas & - & Anaeróbia estrita & Baena et al. (1999) \\
\hline Anaerofustis & + & Anaeróbia estrita & Vos et al. (2009) \\
\hline Bellilinea & - & Anaeróbia estrita & Brenner et al. (2005) \\
\hline Bosea & - & Aeróbio & Brenner et al. (2005) \\
\hline Brevundimonas & - & Aeróbia & Brenner et al. (2005) \\
\hline Desulfobulbus & - & Anaeróbia estrita & Brenner et al. (2005) \\
\hline Desulfomicrobium & - & Anaeróbia & Brenner et al. (2005) \\
\hline Desulfovibrio & - & Anaeróbia & Brenner et al. (2005) \\
\hline Desulfuromonas & - & Anaeróbia estrita & Vos et al. (2009) \\
\hline Fusibacter & + & Anaeróbia estrita & Vos et al. (2009) \\
\hline Gallicola & + & Aeróbia obrigatória & Krieg et al. (2010) \\
\hline Holophaga & - & Anaeróbia & DiPippo et al. (2009) \\
\hline Kosmotoga & - & Anaeróbio & Yamada et al. (2006) \\
\hline Leptolinea & - & Anaeróbia estrita & Yamada et al. (2007) \\
\hline Longilinea & - & Anaeróbia estrita & Brenner et al. (2005); \\
\hline Pseudomonas & - & $\begin{array}{c}\text { Aeróbia e anóxica (algumas espécies } \\
\text { podem usar nitrato como aceptor de } \\
\text { elétrons) }\end{array}$ & Brenner et al. (2005) \\
\hline Sporomusa & $-/+$ & Anaeróbia aerotolerante & Vos et al. (2009) \\
\hline Synergistes & - & Anaeróbia & Allison et al. (1992) \\
\hline Syntrophobacter & - & Anaeróbia estrita & Brenner et al. (2005); \\
\hline Zoogloea & - & $\begin{array}{l}\text { Aeróbia usando oxigênio e anóxica (nitrato } \\
\text { como aceptor de elétrons) }\end{array}$ & Brenner et al. (2005) \\
\hline
\end{tabular}

Entre os 20 gêneros com maior abundância relativa na manta de lodo do reator $\mathrm{R}_{\mathrm{L} 1}$, oito deles possuem representantes relacionados com a degradação de LAS: sete gêneros relacionados com a degradação de compostos aromáticos; dois gêneros relacionados com bactérias capazes de promover a dessulfonação; dois gêneros capazes de $\beta$-oxidação; e um gênero capaz de $\omega$-oxidação. Representantes de Brevundimonas, Desulfomicrobium, Desulfovibrio, Holophaga, Pseudomonas, Sporomusa e Zoogloea, são capazes de degradar compostos com um anel aromático (fenol, tolueno, benzaldeído, hidroxi-, metoxi- e benzoatos) (BRENNER et al., 2005; VOS et al., 2009). Os gêneros Desulfovibrio e Pseudomonas possuem espécies capazes de reações de dessulfonação (KERTESZ et al., 1994; COOK et al., 1998). Foram encontrados dois gêneros, Pseudomonas e Synergistes, com espécies capazes de realizar reações de $\beta$-oxidação (STOVER et al., 2000; KUMAR et al., 
2010). Além disso, Pseudomonas possui representantes capazes de reação de $\omega$-oxidação (LODE e COON, 1971).

Dentre os oito gêneros relacionados com a degradação de LAS, três deles requerem condição aeróbia (Brevundimonas, Pseudomonas e Zoogloea) enquanto os outros cinco podem realizar as reações em condição anaeróbia (Desulfomicrobium, Desulfovibrio, Holophoga, Sporomusa e Synergistes) (Tabela 5.25).

Especificamente, Syntrophobacter possui membros relacionados com a degradação de outro composto aromático, o pentaclorofenol (PCP) em consórcio com Clostridium sp. (TARTAKOVSKY et al., 2001), gênero que foi encontrado na manta de lodo do reator $\mathrm{R}_{\mathrm{L} 1}$ (abundância relativa: $0,03 \%$ ).

Nove gêneros foram relacionados com a degradação de carboidratos: Anaerofustis, Bellilinea, Bosea, Desulfovibrio, Fusibacter, Kosmotoga, Leptolinea, Longilínea e Pseudomonas (BRENNER et al., 2005; YAMADA et al., 2006; YAMADA et al., 2007; DIPIPPO et al., 2009; VOS et al., 2009).

Seis gêneros foram relacionados com a redução de sulfato ou tiossulfato a sulfeto: Desulfobulbus, Desulfomicrobium, Desulforomonas, Desulfovibrio, Fusibacter e Pseudomonas (BRENNER et al., 2005; VOS et al., 2009). A presença de gêneros relacionados com a redução de sulfato foi corroborada pela concentração de sulfato no afluente do reator $\mathrm{R}_{\mathrm{L} 1}$ (6 mg S/L; Tabela 5.12, p. 107).

Dois gêneros foram relacionados com a origem do inóculo (tratamento de água residuária de abatedouro de aves): Aminomonas, que realiza fermentação de aminoácidos (relacionada com a carga de proteínas em abatedouro de aves) (BAENA et al., 1999); e Gallicola, que foi isolado em fezes de galinhas (VOS et al., 2009).

$\mathrm{Na}$ amostra da manta de lodo do reator $\mathrm{R}_{\mathrm{L} 1}$, observou-se a presença de alguns gêneros aeróbios (supracitados), em virtude da presença de resquícios de oxigênio na região da manta 
de lodo. A presença desses resquícios de oxigênio não foi prejudicial aos gêneros anaeróbios, em virtude da estrutura de grânulo do inóculo. Foram encontrados, principalmente, gêneros relacionados com a degradação de carboidratos (9), de LAS (8) e redução de sulfato (6). A presença desses compostos na água residuária de lavanderia favoreceram o desenvolvimento desses microrganismos.

\subsection{Gêneros na amostra da manta de lodo do reator $\mathbf{R}_{\mathbf{S 1}}$}

Entre os 20 gêneros com maior abundância relativa da amostra da manta de lodo do reator $\mathrm{R}_{\mathrm{S} 1}$, foram observados valores entre 0,1 e 5,5\% (Figura 5.66). Quatorze gêneros eram de condição anaeróbia ou anaeróbia estrita (Tabela 5.26). Quatro gêneros eram de condição aeróbia: Comamonas, Pseudomonas, Stenotrophomonas e Zoogloea. A formação de nitrato a partir do cloreto de amônio presente na água residuária sintética $(1.000 \mathrm{mg} / \mathrm{L})$ pode ter permitido o desenvolvimento de Pseudomonas e Zoogloea em condição anóxica. Além disso, não se descarta a possibilidade da presença de pequena quantidade de oxigênio.

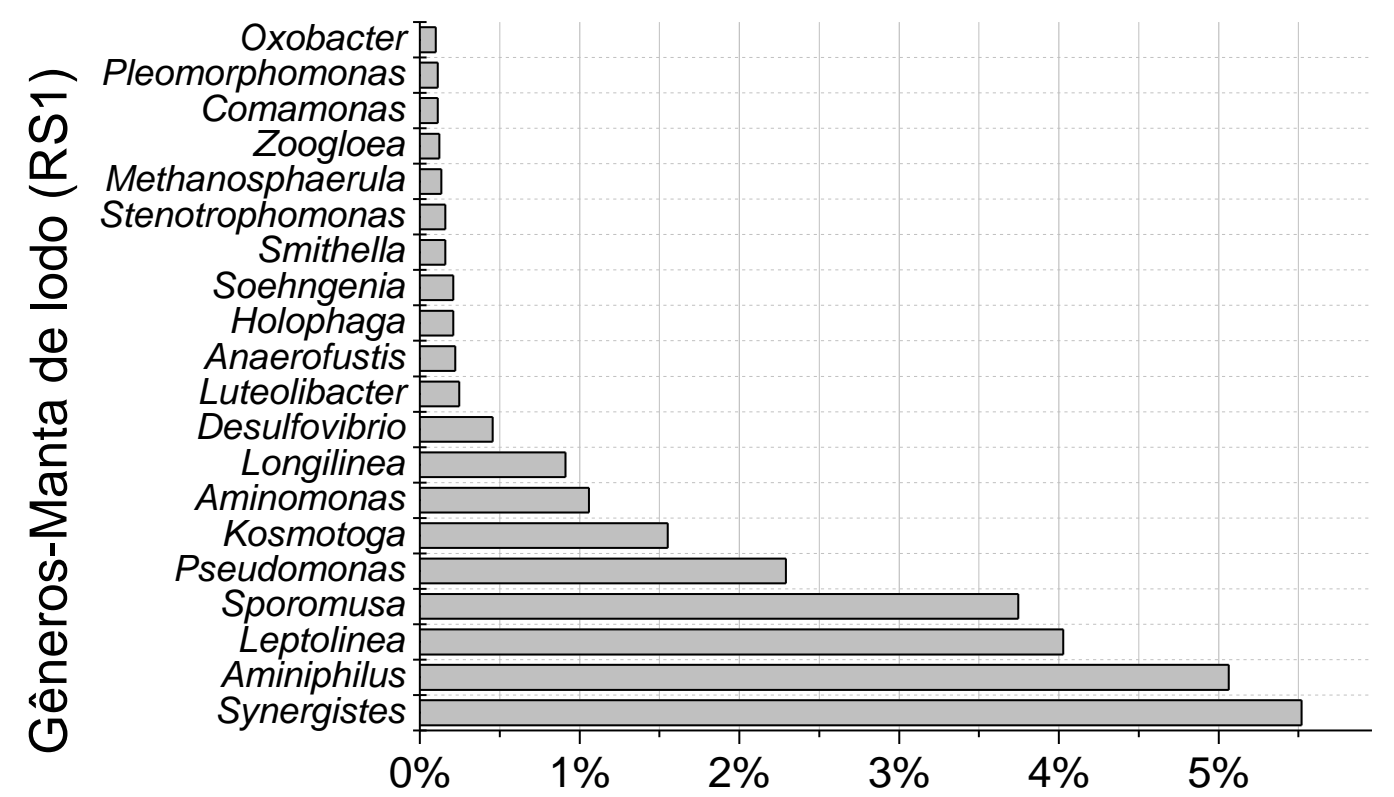

Figura 5.66: Abundância relativa dos 20 gêneros mais frequentes na amostra da manta de lodo do reator $\mathrm{R}_{\mathrm{S} 1}$ ( similaridade $97 \%$ ) 
Tabela 5.26: Descrição dos 20 gêneros de maior abundância relativa na amostra da manta de lodo do reator $\mathrm{R}_{\mathrm{S} 1}$ (similaridade $97 \%$ )

\begin{tabular}{|c|c|c|c|}
\hline Gênero & Gram & Condição & Referência \\
\hline Aminiphilus & - & Anaeróbia estrita & Diaz et al. (2007) \\
\hline Aminomonas & - & Anaeróbia estrita & Baena et al. (1999) \\
\hline Anaerofustis & + & Anaeróbia estrita & Vos et al. (2009) \\
\hline Comamonas & - & Aeróbia & Brenner et al. (2005) \\
\hline Desulfovibrio & - & Anaeróbia & Brenner et al. (2005) \\
\hline Holophaga & - & Anaeróbia & Krieg et al. (2010) \\
\hline Kosmotoga & - & Anaeróbio & DiPippo et al. (2009) \\
\hline Leptolinea & - & Anaeróbia estrita & Yamada et al. (2006) \\
\hline Longilinea & - & Anaeróbia estrita & Yamada et al. (2007) \\
\hline Luteolibacter & - & - & Yoon et al. (2008) \\
\hline Methanosphaerula & + & Anaeróbia estrita & Cadillo-Quiroz et al. (2009) \\
\hline Oxobacter & + & Anaeróbia estrita & Vos et al. (2009) \\
\hline Pleomorphomonas & - & - & Xie e Yokota (2005b) \\
\hline Pseudomonas & - & $\begin{array}{c}\text { Aeróbia e anóxica (algumas espécies } \\
\text { podem usar nitrato como aceptor de } \\
\text { elétrons) }\end{array}$ & Brenner et al. (2005) \\
\hline Smithella & - & Anaeróbia estrita & Brenner et al. (2005) \\
\hline Soehngenia & + & Anaeróbia e aerotolerante & Vos et al. (2009) \\
\hline Sporomusa & $-1+$ & Anaeróbia e aerotolerante & Vos et al. (2009) \\
\hline Stenotrophomonas & - & Aeróbia & Brenner et al. (2005) \\
\hline Synergistes & - & Anaeróbia & Allison et al. (1992) \\
\hline Zoogloea & - & $\begin{array}{l}\text { Aeróbia usando oxigênio e anóxica } \\
\text { (nitrato como aceptor de elétrons) }\end{array}$ & Brenner et al. (2005) \\
\hline
\end{tabular}

Dez gêneros foram relacionados com a degradação de LAS, sendo nove gêneros relacionados com a degradação de compostos aromáticos; três gêneros que realizam dessulfonação; dois gêneros capazes de realizar $\beta$-oxidação; e um gênero capaz de realizar $\omega$ oxidação. Nos gêneros Comamonas, Desulfovibrio, Holophaga, Oxobacter, Pseudomonas, Soehngenia, Sporomusa, Stenotrophomonas e Zoogloea, estão incluídas espécies capazes de degradar compostos com um anel aromático (fenol, tolueno, benzaldeído, hidroxi-, metoxi- e benzoatos) (BRENNER et al., 2005; VOS et al., 2009; KRIEG et al., 2010). Espécies de Comamonas, Desulfovibrio e Pseudomonas são capazes de reações de dessulfonação (KERTESZ et al., 1994; COOK et al., 1998). Algumas espécies de Pseudomonas e Synergistes realizam reações de $\beta$-oxidação (STOVER et al., 2000; KUMAR et al., 2010). 
Além disso, $\omega$-oxidação pode ser realizada por espécies de Pseudomonas (LODE e COON, 1971).

Dentre os 10 gêneros relacionados com a degradação de LAS, quatro requerem condição aeróbia (Comamonas, Pseudomonas, Stenotrophomonas e Zoogloea) e os outros seis gêneros são de condição anaeróbia (Desulfovibrio, Holophoga, Oxobacter, Soehngenia, Sporomusa e Synergistes) (Tabela 5.26).

Oito gêneros foram relacionados com a degradação de carboidratos: Anaerofustis, Comamonas, Desulfovibrio, Kosmotoga, Leptolinea, Longilinea, Pseudomonas e Soehngenia (BRENNER et al., 2005; YAMADA et al., 2006; YAMADA et al., 2007; DIPIPPO et al., 2009; VOS et al., 2009).

Aminiphilus realiza fermentação de aminoácidos, sendo relacionado com a origem do inóculo, uma vez que o tratamento de água residuária de abatedouro de aves apresentava alta carga de proteínas (DIAZ et al., 2007).

Bactérias semelhantes à Luteolibacter são fosfatase alcalina positiva, sendo relacionadas com a concentração de fosfato da água residuária sintética $\left(\mathrm{K}_{2} \mathrm{HPO}_{4} \cdot 3 \mathrm{H}_{2} \mathrm{O}: 400\right.$ mg/L; p. 19) (YOON et al., 2008).

Methanosphaerula pertence ao domínio Archaea e seus membros são metanogênicos hidrogenotróficos (consomem hidrogênio para produção de metano) (CADILLO-QUIROZ et al., 2009). Nesse aspecto, a presença dos gêneros Smithella e Longilinea foi relacionada à sintrofia com microrganismos hidrogenotróficos (BRENNER et al., 2005; YAMADA et al., 2007).

O gênero Pleomorphomonas caracteriza-se por fixar nitrogênio, sendo presente devido à riqueza do inóculo.

Foram encontrados gêneros aeróbios (supracitados) na amostra da manta de lodo do reator $\mathrm{R}_{\mathrm{S} 1}$, cuja presença foi atribuída a resquícios de oxigênio na região da manta de lodo. 
Destacou-se a presença de gêneros capazes de degradar LAS (10) e carboidratos (8), relacionados com a disponibilidade de LAS padrão e extrato de levedura na água residuária sintética.

\subsection{Gêneros na amostra do separador de fases reator $R_{L 1}$}

Para 20 gêneros com maior abundância relativa na biomassa do separador de fases do reator $\mathrm{R}_{\mathrm{L} 1}$, foram observados valores entre 0,2 e $21 \%$ (Figura 5.67). Destacou-se similaridade a Zoogloea (21\%), sendo que esse gênero representou cerca de metade da abundância relativa dentre aqueles classificados nessa amostra (45\%). Zoogloea foi relacionada com a degradação de LAS, devido à capacidade de meta clivagem de anel aromático de benzeno (BRENNER et al., 2005). As características do gênero Zoogloea foram descritas no item 5.4.4.2.6 (p. 155).

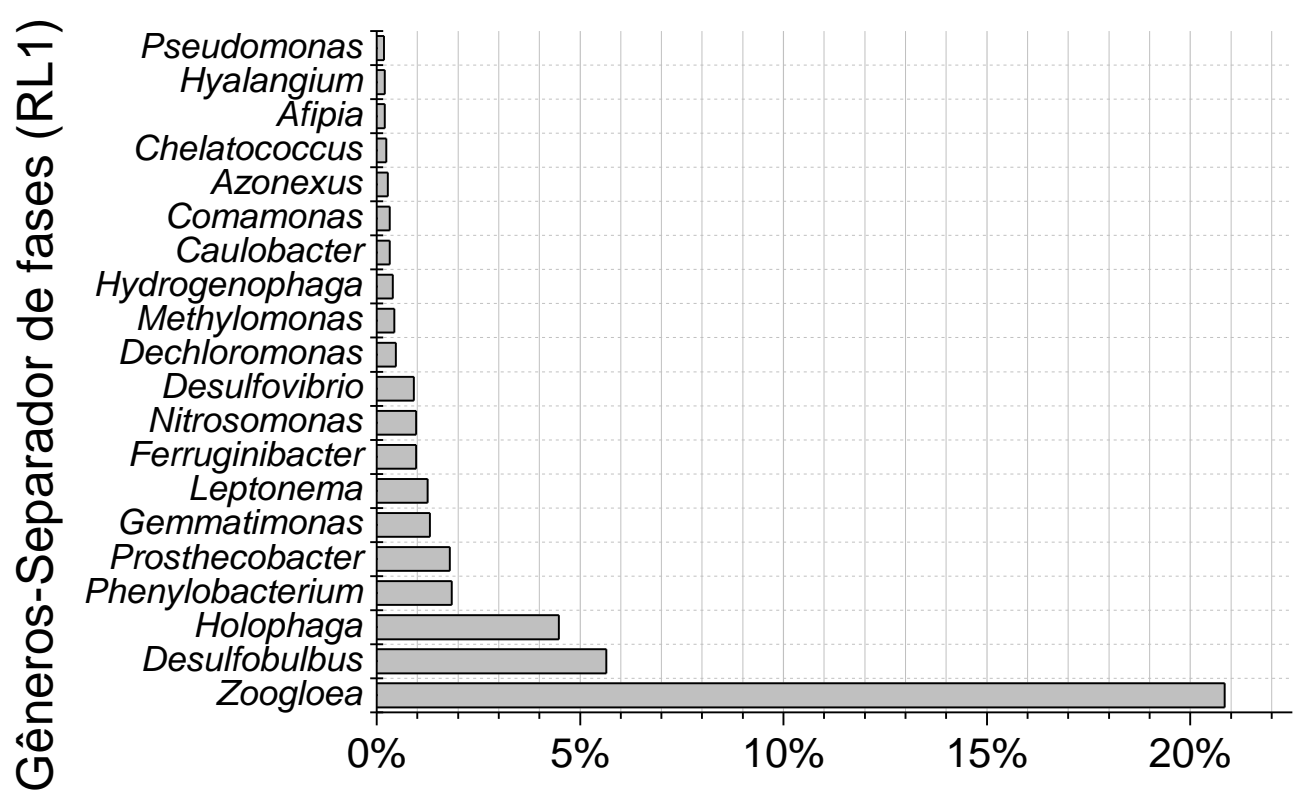

Figura 5.67: Abundância relativa dos 20 gêneros mais frequentes na amostra da biomassa do separador de fases do reator $\mathrm{R}_{\mathrm{L} 1}$ (similaridade 97\%) 
Tabela 5.27: Descrição dos 20 gêneros de maior abundância relativa da amostra da biomassa do separador de fases do reator $\mathrm{R}_{\mathrm{L} 1}$ (similaridade $97 \%$ )

\begin{tabular}{|c|c|c|c|}
\hline Gênero & Gram & Condição & Referência \\
\hline Afipia & - & Aeróbia & Brenner et al. (2005) \\
\hline Azonexus & - & Aeróbia & Brenner et al. (2005) \\
\hline Caulobacter & - & Aeróbia & Brenner et al. (2005) \\
\hline Chelatococcus & - & Aeróbia obrigatória & Brenner et al. (2005) \\
\hline Comamonas & - & Aeróbia & Brenner et al. (2005) \\
\hline Dechloromonas & - & Anaeróbia facultativa & Brenner et al. (2005) \\
\hline Desulfobulbus & - & Anaeróbia estrita & Brenner et al. (2005) \\
\hline Desulfovibrio & - & Anaeróbia & Brenner et al. (2005) \\
\hline Ferruginibacter & - & Aeróbia obrigatória & Lim et al. (2009) \\
\hline Gemmatimonas & - & Aeróbia & Krieg et al. (2010) \\
\hline Holophaga & - & Anaeróbia & Krieg et al. (2010) \\
\hline Hyalangium & & - & Brenner et al. (2005) \\
\hline Hydrogenophaga & - & Aeróbia, desnitrificante heterotrófica & Brenner et al. (2005) \\
\hline Leptonema & - & Aeróbia obrigatória & Krieg et al. (2010) \\
\hline Methylomonas & - & Aeróbia obrigatória & Brenner et al. (2005) \\
\hline Nitrosomonas & - & Anaeróbia facultativa & Brenner et al. (2005) \\
\hline Phenylobacterium & - & Aeróbia obrigatória & Brenner et al. (2005) \\
\hline Prosthecobacter & - & Aeróbia obrigatória & Krieg et al. (2010) \\
\hline Pseudomonas & - & $\begin{array}{c}\text { Aeróbia e anóxica (algumas espécies } \\
\text { podem usar nitrato como aceptor de } \\
\text { elétrons) }\end{array}$ & Lode e Coon (2005) \\
\hline Zoogloea & - & $\begin{array}{l}\text { Aeróbia usando oxigênio e anóxica } \\
\text { (nitrato como aceptor de elétrons) }\end{array}$ & Brenner et al. (2005) \\
\hline
\end{tabular}

Foram encontrados três gêneros anaeróbios ou anaeróbios estritos: Desulfobulbus, Desulfovibrio e Holophaga. Em virtude do oxigênio dissolvido na região do separador de fases (indicada pela coloração rosa observada após adição de resazurina; item 5.4.2, p. 111), foram encontrados 15 gêneros aeróbios (Tabela 5.27) e outros dois gêneros anaeróbios facultativos (Dechloromonas e Nitrosomonas).

Oito gêneros foram relacionados com a degradação de LAS; oito gêneros capazes de realizar a degradação de compostos aromáticos; e quatro gêneros capazes de realizar dessulfonação. Os gêneros Comamonas, Dechloromonas, Desulfovibrio, Gemmatimonas, Holophaga, Hydrogenophaga, Pseudomonas e Zoogloea, incluem espécies capazes de degradar compostos com um anel aromático (fenol, tolueno, benzaldeído, hidroxi-, metoxi- e benzoatos) (BRENNER et al., 2005; CHAKRABORTY e COATES, 2005; SALINERO et al., 
2009; KRIEG et al., 2010). Foram encontrados quatro gêneros com representantes capazes de reações de dessulfonação: Comamonas, Dechloromonas, Desulfovibrio, Hydrogenophaga e Pseudomonas (KERTESZ et al., 1994; COOK et al., 1998).

Entre os gêneros relacionados com a degradação de LAS, seis requerem condição aeróbia (Comamonas, Gemmatimonas, Hydrogenophaga, Pseudomonas e Zoogloea), dois gêneros são anaeróbios (Desulfovibrio e Holophoga) e o gênero Dechloromonas é anaeróbio facultativo (Tabela 5.27).

O gênero Leptonema é capaz de consumir alcoóis e ácidos de cadeia longa (KRIEG et al., 2010). Além disso, foram encontrados gêneros capazes de degradar outros compostos aromáticos: fenilalanina (Chelatococcus e Phenylobacterium) e naftil fosfato (Ferruginibacter) (BRENNER et al., 2005; LIM et al., 2009; KRIEG et al., 2010).

Seis gêneros foram relacionados com a degradação de carboidratos: Comamonas, Caulobacter, Desulfovibrio, Hydrogenophaga, Prosthecobacter e Pseudomonas (BRENNER et al., 2005; KRIEG et al., 2010).

Três gêneros foram relacionados com a redução de sulfato a sulfeto: Desulfobulbus, Desulfovibrio e Pseudomonas (BRENNER et al., 2005). Atribuiu-se a presença desses gêneros às fontes de enxofre na água residuária de lavanderia, sendo observada concentração de sulfato de $6 \mathrm{mg}$ S/L no afluente do reator $\mathrm{R}_{\mathrm{L} 1}$ (Tabela 5.12, p. 107).

Nitrosomonas realiza oxidação de amônio, sendo relacionado com a presença de fontes de nitrogênio na água residuária de lavanderia (concentração de NTK estimada em torno de $2 \mathrm{mg} \mathrm{N} / \mathrm{L}$, considerando a diluição aplicada).

Os membros do gênero Methylomonas são metanotróficas obrigatórias (consomem metano), sendo sua presença atribuída à produção de metano no reator $\mathrm{R}_{\mathrm{L} 1}$.

A presença dos gêneros Afipia e Azonexus foi relacionada à riqueza da comunidade microbiana do reator. 
Verificou-se na amostra da biomassa do separador de fases do reator $\mathrm{R}_{\mathrm{L} 1}$ maior quantidade de gêneros aeróbio e anaeróbio facultativo, em virtude da difusão de oxigênio nessa região. Observou-se significativa abundância relativa (21\%) do gênero Zoogloea, capaz de degradar compostos aromáticos, sendo, portanto, relacionado com a alta remoção de LAS no separador de fases do reator $\mathrm{R}_{\mathrm{L} 1}(90 \%)$. Atribuiu-se a presença de gêneros relacionados com a degradação de LAS (8), carboidratos (6) e redução de sulfato (6) à existência de tais compostos na água residuária de lavanderia, favorecendo o desenvolvimento desses microrganismos.

\subsection{Gêneros na amostra do separador de fases reator $R_{\mathbf{S 1}}$}

A abundância relativa dos 20 gêneros mais frequentes variou entre 0,5 e 34\%, destacando-se a presença de Nitrosomonas (Figura 5.68). Ressalta-se que os gêneros classificados na amostra da biomassa do separador de fases do reator $\mathrm{R}_{\mathrm{S} 1}$ representaram $77 \%$ da abundância relativa; assim, a presença de Nitrosomonas foi significativa na comunidade microbiana dessa amostra. Representantes do gênero Nitrosomonas caracterizam-se por realizar oxidação de amônio a nitrito, mediante reação que consome alcalinidade do meio:

$$
\mathrm{NH}_{4}^{+}+3 / 2 \mathrm{O}_{2} \rightarrow \mathrm{NO}_{2}^{-}+\mathrm{H}_{2} \mathrm{O}+2 \mathrm{H}^{+}
$$

A alimentação do reator $R_{S 1}$ fornecia amônio em alta concentração, na forma de cloreto de amônio $\left(\mathrm{NH}_{4} \mathrm{Cl}\right)$ em concentração de $1.000 \mathrm{mg} / \mathrm{L}$ (Tabela 4.1, p. 19). Além disso, observou-se alto consumo de alcalinidade no reator $\mathrm{R}_{\mathrm{S} 1}$, com a redução da alcalinidade total de 564 para $197 \mathrm{mg} \mathrm{CaCO} / \mathrm{L}$ (Tabela 5.12, p. 107). A presença de Nitrosomonas também poderia estar relacionada com a degradação de compostos aromáticos, uma vez que N. europeae é capaz de degradar tolueno e alquilbenzenos (KEENER e ARP, 1994). Todavia, Brandt et al. (2001) não observaram degradação de LAS em cultura de $N$. europeae, além da cessação do crescimento em $15 \mathrm{mg} / \mathrm{L}$ de surfactante. Assim, atribuiu-se a alta abundância 
relativa de Nitrosomonas (34\%) à alta concentração de amônio na água residuária sintética, corroborada pelo alto consumo de alcalinidade do reator $\mathrm{R}_{\mathrm{S} 1}$. Adicionalmente, ressalta-se a possibilidade de presença significativa do gênero Nitrosomonas na biomassa do separador de fases dos reatores $\mathrm{R}_{35 \mathrm{D}}$ e $\mathrm{R}_{\mathrm{BCS}}$, devido ao elevado consumo de alcalinidade observado (item 5.3, p. 67) e à presença de alta concentração de amônio na água residuária sintética usada nesses reatores $\left(\mathrm{NH}_{4} \mathrm{Cl}: 1.000 \mathrm{mg} / \mathrm{L}\right.$; Tabela 4.1, p. 19).

Entre os 20 gêneros com maior frequência, foram encontrados sete deles capazes de desnitrificação: Azospira, Bosea, Dechloromonas, Flavobacterium, Magnetospirillum, Pseudomonas e Zoogloea (BRENNER et al., 2005; KRIEG et al., 2010). Além disso, foram observados dois gêneros conhecidos por realizar a oxidação de nitrito: Nitrosospira e Nitrobacter, com abundância relativa de 0,05 e 0,02\%, respectivamente (AHN, 2006).

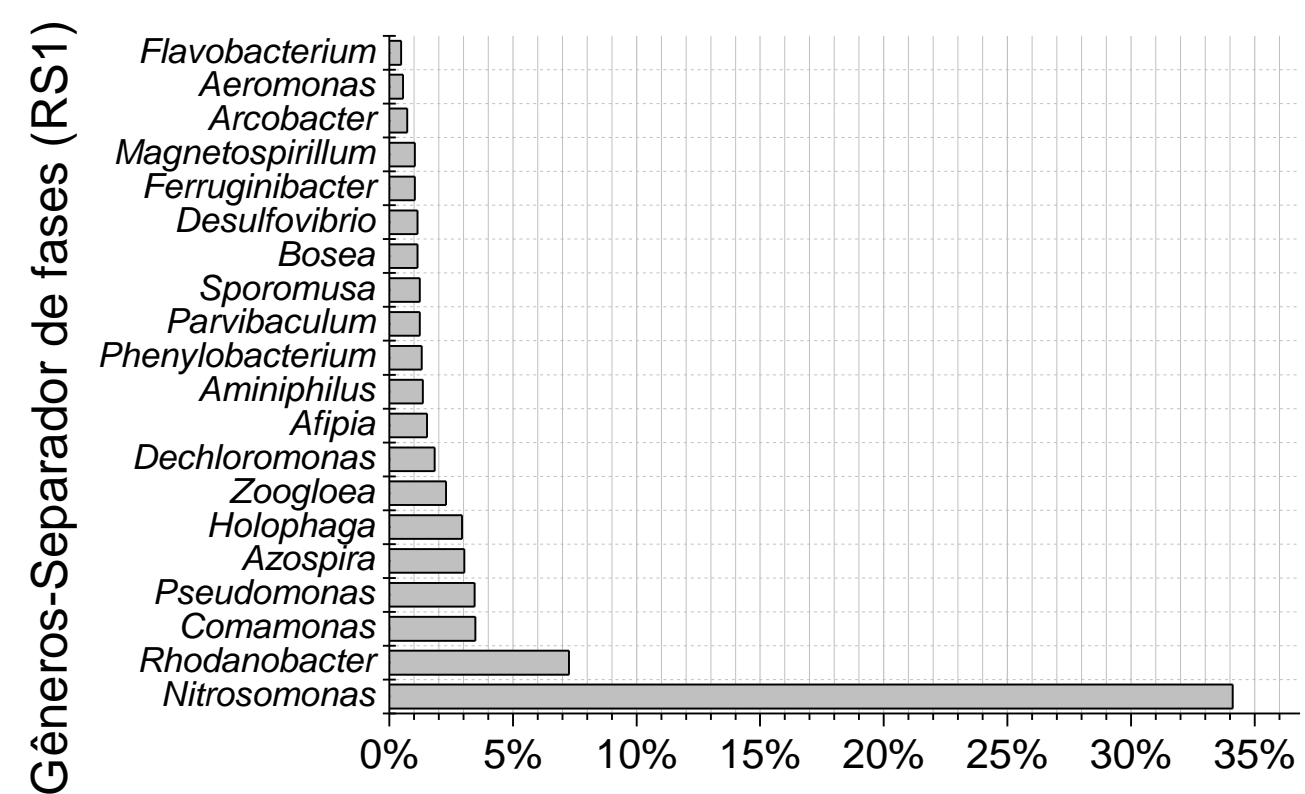

Figura 5.68: Abundância relativa dos 20 gêneros mais frequentes na amostra da biomassa do separador de fases do reator $\mathrm{R}_{\mathrm{S} 1}$ (similaridade $97 \%$ )

Foram encontrados 11 gêneros de condição aeróbia (Tabela 5.28), além de quatro gêneros anaeróbios facultativos (Aeromonas, Arcobacter, Dechloromonas e Nitrosomonas) e um microaerofílico (Magnetospirillum). Quatro gêneros eram de condição anaeróbia ou 
anaeróbia estrita (Aminiphilus, Desulfovibrio, Holophaga e Sporomusa). Atribuiu-se a presença de gêneros aeróbio, anaeróbio facultativo e microaerofílico à difusão de oxigênio na região do separador de fases (verificado pela coloração rosa após adição de resazurina; item 5.4.2, p. 111).

Tabela 5.28: Descrição dos 20 gêneros de maior abundância relativa da amostra da biomassa do separador de fases do reator $\mathrm{R}_{\mathrm{S} 1}$ (similaridade $97 \%$ )

\begin{tabular}{|c|c|c|c|}
\hline Gênero & Gram & Condição & Referência \\
\hline Aeromonas & - & Anaeróbia facultativa & Brenner et al. (2005) \\
\hline Afipia & - & Aeróbia & Brenner et al. (2005) \\
\hline Aminiphilus & & Anaeróbia estrita & Diaz et al. (2007) \\
\hline Arcobacter & - & Anaeróbia facultativa & Brenner et al. (2005) \\
\hline Azospira & & $\begin{array}{l}\text { Aeróbia, microaerofílica quando } \\
\text { fixando } \mathrm{N}_{2}\end{array}$ & Brenner et al. (2005) \\
\hline Bosea & - & Aeróbia & Brenner et al. (2005) \\
\hline Comamonas & - & Aeróbia & Brenner et al. (2005) \\
\hline Dechloromonas & - & Anaeróbia facultativa & Brenner et al. (2005) \\
\hline Desulfovibrio & - & Anaeróbia & Brenner et al. (2005) \\
\hline Ferruginibacter & - & Aeróbia obrigatória & Lim et al. (2009) \\
\hline Flavobacterium & - & $\begin{array}{l}\text { Aeróbia obrigatória; poucas } \\
\text { microaeróbia/anaeróbia }\end{array}$ & Krieg et al. (2010) \\
\hline Holophaga & - & Anaeróbia & Krieg et al. (2010) \\
\hline Magnetospirillum & - & Microaerofílico & Brenner et al. (2005) \\
\hline Nitrosomonas & - & Anaeróbia facultativa & Brenner et al. (2005) \\
\hline Parvibaculum & - & Aeróbia & Schleheck et al. (2004b) \\
\hline Phenylobacterium & - & Aeróbia obrigatória & Brenner et al. (2005) \\
\hline Pseudomonas & - & $\begin{array}{c}\text { Aeróbia e anóxica (algumas espécies } \\
\text { podem usar nitrato como aceptor de } \\
\text { elétrons) }\end{array}$ & Brenner et al. (2005) \\
\hline Rhodanobacter & - & Aeróbia & Brenner et al. (2005) \\
\hline Sporomusa & $-/+$ & Anaeróbia e aerotolerante & Vos et al. (2009) \\
\hline Zoogloea & - & $\begin{array}{l}\text { Aeróbia usando oxigênio e anóxica } \\
\text { (nitrato como aceptor de elétrons) }\end{array}$ & Brenner et al. (2005) \\
\hline
\end{tabular}

Dez gêneros foram relacionados com a degradação de LAS, sendo nove relacionados com a degradação de compostos aromáticos; quatro gêneros capazes de realizar dessulfonação; dois gêneros capazes de realizar $\beta$-oxidação; e dois gêneros capazes de realizar

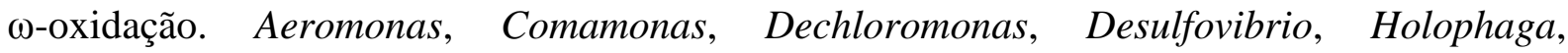
Pseudomonas, Rhodanobacter, Sporomusa e Zoogloea, possuem espécies capazes de 
degradar compostos com um anel aromático (fenol, tolueno, benzaldeído, hidroxi-, metoxi- e benzoatos) (BRENNER et al., 2005; SALINERO et al., 2009; VOS et al., 2009; KRIEG et al., 2010). Quatro gêneros possuem espécies capazes de reações de dessulfonação: Aeromonas, Comamonas, Desulfovibrio e Pseudomonas (KERTESZ et al., 1994; COOK et al., 1998; DENGER e COOK, 1999). Dois gêneros possuem espécies capazes de realizar reações de $\beta$-oxidação e $\omega$-oxidação: Pseudomonas e Parvibaculum, este último gênero foi isolado em cultura com LAS (LODE e COON, 1971; STOVER et al., 2000; SCHLEHECK et al., 2004b).

Dos gêneros relacionados com a degradação de LAS, cinco requerem condição aeróbia (Comamonas, Parvibaculum, Pseudomonas, Rhodanobacter e Zoogloea), três gêneros são anaeróbios (Desulfovibrio, Holophoga e Sporomusa) e dois gêneros são anaeróbios facultativos (Aeromonas e Dechloromonas) (Tabela 5.28).

Três gêneros possuem espécies capazes de degradar outros compostos aromáticos: Ferruginibacter (naftil fosfato), Flavobacterium (PCP) e Phenylobacterium (fenilalanina) (BRENNER et al., 2005; LIM et al., 2009; KRIEG et al., 2010).

Seis gêneros foram relacionados com a degradação de carboidratos: Aeromonas, Bosea, Comamonas, Desulfovibrio, Flavobacterium e Pseudomonas (BRENNER et al., 2005; KRIEG et al., 2010).

Dois gêneros foram relacionados com a redução de sulfato a sulfeto: Desulfobulbus e Desulfovibrio (BRENNER et al., 2005). As possíveis fontes de enxofre foram as proteínas presentes no extrato de levedura usado na água residuária sintética (Tabela 4.6, p. 33) e o LAS, que possui um grupo aromático sulfonado.

Atribuiu-se a presença de dois gêneros à origem do inóculo (tratamento de abatedouro de aves), uma vez que Aminiphilus fermenta aminoácidos (relacionado com a carga de 
proteínas no abatedouro de aves) e Arcobacter é encontrado em carcaças de frango (HOUF et al., 2005; DIAZ et al., 2007).

A presença de Afipia foi relacionada à riqueza da comunidade microbiana do reator.

A maior abundância relativa da amostra da biomassa do separador de fases do reator $\mathrm{R}_{\mathrm{S} 1}$ foi atribuída a Nitrosomonas, cuja presença foi relacionada à disponibilidade de amônio em alta concentração. Em virtude da abundância relativa de Nitrosomonas, foram encontrados gêneros relacionados com a redução de nitrato (7). Além desse gênero, foram encontrados outros relacionados com a degradação de LAS (10) e carboidratos (6), atribuídas à presença de LAS padrão e extrato de levedura na água residuária sintética.

\subsection{Gêneros relacionados com a degradação de LAS}

Dentre os 147 gêneros classificados, 32 deles foram relacionados com a degradação de LAS, sendo 14 gêneros mencionados em estudos com LAS (Tabela 5.29 e Tabela 5.30). A maioria dos gêneros (27) foi relacionada com a degradação de compostos com um anel aromático (fenol, tolueno, benzaldeído, hidroxi-, metoxi- e benzoatos) (Tabela 5.29). Sete gêneros possuem membros capazes de reações de dessulfonação: Acinetobacter, Aeromonas, Clostridium, Comamonas, Desulfovibrio, Hydrogenophaga e Pseudomonas (Tabela 5.30). Cinco gêneros foram relacionados com reações de $\beta$-oxidação: Desulfovirga, Parvibaculum, Pseudomonas, Synergistes e Syntrophomonas (Tabela 5.30). Dois gêneros possuem membros capazes de reações de $\omega$-oxidação: Parvibaculum e Pseudomonas (Tabela 5.30). 
Tabela 5.29: Descrição de gêneros capazes de degradação de compostos aromáticos (fenol, tolueno, benzaldeído, hidroxi-, metoxi- e benzoatos), relacionados com a presença em estudos com LAS (referências em negrito)

\begin{tabular}{|c|c|c|c|c|c|c|}
\hline Gênero & Fenol & $\begin{array}{c}\text { Tolue- } \\
\text { no }\end{array}$ & $\begin{array}{c}\text { Benzal- } \\
\text { deído }\end{array}$ & $\begin{array}{l}\text { Hidroxi-, } \\
\text { metoxi- e } \\
\text { benzoatos }\end{array}$ & $\begin{array}{l}\text { Presença } \\
\text { em LAS }\end{array}$ & Referências \\
\hline Acinetobacter & - & - & - & + & + & $\begin{array}{l}\text { Brenner et al. (2005); Abboud } \\
\text { et al. (2007) }\end{array}$ \\
\hline Azoarcus & + & + & - & + & - & $\begin{array}{l}\text { Anders et al.(1995); Gescher et } \\
\text { al. }(2002) \text {; Brenner } \text { et al. } \\
(2005)\end{array}$ \\
\hline Brevundimonas & + & - & - & - & - & $\begin{array}{l}\text { Segers et al. (1994); Hong e } \\
\text { Raushel (1996); Brenner et al. } \\
(2005)\end{array}$ \\
\hline Clostridium & - & - & - & + & + & $\begin{array}{l}\text { Hsu et al. (1990); Mechichi et } \\
\text { al. (1999); Chien et al. (2005); } \\
\text { Mechichi et al. (2005); Lara- } \\
\text { Martin et al. (2007); Duarte } \\
\text { et al. (2008); Vos et al. (2009); } \\
\text { Duarte et al. (2010b); } \\
\text { Oliveira et al. (2010); }\end{array}$ \\
\hline Comamonas & + & + & - & + & + & $\begin{array}{l}\text { Schleheck et al. (2004a); } \\
\text { Brenner et al. (2005); } \\
\text { Schleheck et al. (2010) }\end{array}$ \\
\hline Dechloromonas & - & + & - & + & + & $\begin{array}{l}\text { Achenbach et al. (2001); } \\
\text { Brenner } \text { et al. (2005); Delforno } \\
\text { et al. (2012); Duarte } \text { et al. } \\
\text { (2010a); Chakraborty et al. } \\
\text { (2005); Chakraborty e Coates } \\
\text { (2005); Salinero et al.(2009) }\end{array}$ \\
\hline Desulfomicrobium & - & - & - & + & - & Brenner et al. (2005) \\
\hline Desulfomonile & - & - & - & + & - & Brenner et al. (2005) \\
\hline Desulfonema & - & - & - & + & - & Brenner et al. (2005) \\
\hline Desulfovibrio & - & - & + & + & + & $\begin{array}{l}\text { Zellner et al. (1989); Zellner et } \\
\text { al. (1990); Reichenbecher et al. } \\
\text { (1997); Brenner et al. (2005); } \\
\text { Duarte et al. (2010a) }\end{array}$ \\
\hline Gemmatimonas & - & - & - & + & - & Krieg et al. (2010) \\
\hline Geobacter & + & + & + & + & + & $\begin{array}{l}\text { Brenner et al. (2005); Lara- } \\
\text { Martin et al. (2007); Delforno } \\
\text { et al. (2012) }\end{array}$ \\
\hline Holophaga & - & - & - & + & + & $\begin{array}{l}\text { Liesack et al. (1994); Oliveira } \\
\text { et al. (2009); Krieg et al. } \\
\text { (2010) }\end{array}$ \\
\hline Hydrogenophaga & + & - & - & + & - & $\begin{array}{l}\text { Dangmann et al. (1989); Cook } \\
\text { (1998); Brenner et al. (2005) }\end{array}$ \\
\hline Methylibium & + & - & - & + & - & Nakatsu et al. (2006) \\
\hline Oxobacter & - & - & - & + & - & Vos et al. (2009) \\
\hline Pigmentiphaga & - & - & - & + & - & Brenner et al. (2005) \\
\hline Pseudolabrys & - & - & - & + & - & Kämpfer et al. (2006) \\
\hline
\end{tabular}


Tabela 5.29: Descrição de gêneros capazes de degradação de compostos aromáticos (fenol, tolueno, benzaldeído, hidroxi-, metoxi- e benzoatos), relacionados com a presença em estudos com LAS (referências em negrito) (cont.)

\begin{tabular}{|c|c|c|c|c|c|c|}
\hline Gênero & Fenol & $\begin{array}{c}\text { Tolue- } \\
\text { no }\end{array}$ & $\begin{array}{c}\text { Benzal- } \\
\text { deído }\end{array}$ & $\begin{array}{l}\text { Hidroxi-, } \\
\text { metoxi- e } \\
\text { benzoatos }\end{array}$ & $\begin{array}{l}\text { Presença } \\
\text { em LAS }\end{array}$ & Referências \\
\hline Pseudomonas & - & + & - & + & + & $\begin{array}{l}\text { Jimenez et al. (1991); } \\
\text { Sigoillot e Nguyen (1992); } \\
\text { Kertesz et al. (1999); Stover } \\
\text { et al. (2000); Almendariz et } \\
\text { al. (2001); Brenner } \text { et al. } \\
\text { (2005); Lara-Martin } \text { et al. } \\
\text { (2007); Duarte } \text { et al. } \\
\text { (2010a); Martinez-Pascual } \\
\text { et al. (2010) }\end{array}$ \\
\hline Rhodanobacter & - & - & - & + & - & $\begin{array}{l}\text { Brenner et al. (2005); Zhang } \\
\text { et al. (2011) }\end{array}$ \\
\hline Rhodopseudomonas & - & - & - & + & - & $\begin{array}{l}\text { Harwood e Gibson (1988); } \\
\text { Brenner et al. (2005) }\end{array}$ \\
\hline Sedimentibacter & + & - & - & + & + & $\begin{array}{l}\text { Lara-Martin et al. (2007); } \\
\text { Vos et al. (2009) }\end{array}$ \\
\hline Soehngenia & - & - & + & - & - & $\begin{array}{l}\text { Parshina et al. (2003); Vos et } \\
\text { al. (2009) }\end{array}$ \\
\hline Sporomusa & - & - & - & + & + & $\begin{array}{l}\text { Vos et al. (2009); Delforno et } \\
\text { al. (2012) }\end{array}$ \\
\hline Stenotrophomonas & - & + & - & + & + & $\begin{array}{l}\text { Brenner et al. (2005); Lara- } \\
\text { Martin et al. (2007) }\end{array}$ \\
\hline Variovorax & + & - & - & + & + & $\begin{array}{l}\text { Brenner et al. (2005); Duarte } \\
\text { et al. (2010b) }\end{array}$ \\
\hline Zoogloea & + & + & - & + & - & $\begin{array}{l}\text { Unz e Farrah (1972); Arvin et } \\
\text { al. (1989); Brenner } \text { et al. } \\
\text { (2005) }\end{array}$ \\
\hline
\end{tabular}


Tabela 5.30: Descrição de gêneros capazes de reações de dessulfonação, $\beta$ e $\omega$ - oxidação, relacionados com a presença em estudos com LAS (ref. em negrito)

\begin{tabular}{|c|c|c|c|c|c|}
\hline Gênero & $\begin{array}{l}\text { Dessul- } \\
\text { fonação }\end{array}$ & $\begin{array}{l}\beta \text {-oxi- } \\
\text { dação }\end{array}$ & $\begin{array}{l}\omega \text {-oxi- } \\
\text { dação }\end{array}$ & $\begin{array}{l}\text { Presença } \\
\text { em LAS }\end{array}$ & Referências \\
\hline Acinetobacter & + & - & - & + & $\begin{array}{l}\text { Brenner et al. (2005); Abboud et al. } \\
\text { (2007) }\end{array}$ \\
\hline Aeromonas & + & - & - & + & $\begin{array}{l}\text { Jimenez et al. (1991); Denger e Cook } \\
\text { (1999); Brenner et al. (2005) }\end{array}$ \\
\hline Clostridium & + & - & - & + & $\begin{array}{l}\text { Hsu et al. (1990); Mechichi et al. } \\
\text { (1999); Chien et al. (2005); Mechichi } \\
\text { et al. (2005); Lara-Martin et al. } \\
\text { (2007); Duarte et al. (2008); Vos et } \\
\text { al. (2009); Duarte et al. (2010b); } \\
\text { Oliveira et al. (2010); }\end{array}$ \\
\hline Comamonas & + & - & - & + & $\begin{array}{l}\text { Schleheck et al. (2004a); Brenner et } \\
\text { al. (2005); Schleheck et al. (2010) }\end{array}$ \\
\hline Desulfovibrio & + & - & - & + & $\begin{array}{l}\text { Zellner et al. (1989); Zellner et al. } \\
\text { (1990); Reichenbecher et al. (1997); } \\
\text { Brenner et al. (2005); Duarte et al. } \\
\text { (2010a) }\end{array}$ \\
\hline Desulfovirga & - & + & - & - & Brenner et al. (2005) \\
\hline Hydrogenophaga & + & - & - & - & $\begin{array}{l}\text { Dangmann et al. (1989); Cook (1998); } \\
\text { Brenner et al. (2005) }\end{array}$ \\
\hline Parvibaculum & - & + & + & + & $\begin{array}{l}\text { Dong et al. (2004); Schleheck et al. } \\
\text { (2004a); Schleheck et al. (2004b); } \\
\text { Schleheck e Cook (2005); Martinez- } \\
\text { Pascual } \text { et al. (2010) }\end{array}$ \\
\hline Pseudomonas & + & + & + & + & $\begin{array}{l}\text { Lode e Coon (1971); Jimenez et al. } \\
\text { (1991); Sigoillot e Nguyen (1992); } \\
\text { Beilen et al. (1994); Cook (1998); } \\
\text { Kertesz et al. (1999); Stover } \text { et al. } \\
\text { (2000); Almendariz et al. (2001); } \\
\text { Brenner } \text { et al. (2005); Lara-Martin et } \\
\text { al. (2007); Duarte } \text { et al. (2010a); } \\
\text { Martinez-Pascual } \text { et al. (2010) }\end{array}$ \\
\hline Synergistes & - & + & - & - & Kumar et al. (2010) \\
\hline Syntrophomonas & - & + & - & - & $\begin{array}{l}\text { McInerney et al. (1981); Vos et al. } \\
\text { (2009) }\end{array}$ \\
\hline
\end{tabular}

A presença de diversos gêneros relacionados com a degradação de LAS (32) corroborou a necessidade de consórcios microbianos para a degradação do surfactante (JIMENEZ et al., 1991; KHLEIFAT, 2006a). Atribuiu-se a necessidade de consórcios microbianos à complexidade das reações necessária para a degradação de LAS, que envolvem quebra de anel aromático e reações de dessulfonação, $\beta$ e $\omega$-oxidação. Entre os gêneros 
encontrados, apenas Pseudomonas possui espécies capazes de degradação de compostos aromáticos, dessulfonação, $\beta$ e $\omega$-oxidação (Tabela 5.29 e Tabela 5.30). Os sete gêneros capazes de dessulfonação podem degradar outros compostos aromáticos, mas não são capazes de quebrar a cadeia alquílica do LAS (Tabela 5.29 e Tabela 5.30). Dentre os cinco gêneros capazes de $\beta$ ou $\omega$-oxidação, apenas dois gêneros são capazes de degradar outros compostos aromáticos: Synergistes (Dihidroxipiridina - DHP) e Pseudomonas (Tabela 5.29).

Com exceção do gênero Synergistes, todos os demais gêneros relacionados com a degradação de LAS podem crescer usando ácidos orgânicos voláteis ou alcoóis (Tabela 5.31). A degradação de LAS envolve reações mais complexas (supracitadas) que as reações para consumo de ácidos orgânicos voláteis ou alcoóis. Assim, a degradação de LAS é desfavorecida na presença de compostos orgânicos mais simples (ácidos orgânicos voláteis ou alcoóis), devido à possibilidade de uso desses compostos pelos mesmos microrganismos responsáveis pela degradação de surfactante. O favorecimento da degradação de LAS na menor presença de compostos orgânicos mais simples foi corroborado pela maior degradação de surfactante (76\%), em menor concentração de co-substratos (COE: 0,03 g DQO/g STV.d; p. 83). 
Tabela 5.31: Descrição dos gêneros relacionados com a degradação de LAS

\begin{tabular}{|c|c|c|c|c|}
\hline Gênero & Gram & $\begin{array}{l}\text { AOV / } \\
\text { Alcoóis }\end{array}$ & Condição & Referência \\
\hline Acinetobacter & - & + & Aeróbia & Brenner et al. (2005) \\
\hline Aeromonas & - & + & Anaeróbia facultativa & Brenner et al. (2005) \\
\hline Azoarcus & - & + & Aeróbia/anóxica (reduzindo nitrato) & Brenner et al. (2005) \\
\hline Brevundimonas & - & + & Aeróbia & Brenner et al. (2005) \\
\hline Clostridium & + & + & $\begin{array}{c}\text { Maioria anaeróbia estrita; algumas } \\
\text { aerotolerantes }\end{array}$ & Vos et al. (2009) \\
\hline Comamonas & - & + & Aeróbia & Brenner et al. (2005) \\
\hline Dechloromonas & - & + & Anaeróbia facultativa & Brenner et al. (2005) \\
\hline Desulfomicrobium & - & + & Anaeróbia & Brenner et al. (2005) \\
\hline Desulfomonile & - & + & Anaeróbia estrita & Brenner et al. (2005) \\
\hline Desulfonema & - & + & Anaeróbia estrita & Brenner et al. (2005) \\
\hline Desulfovibrio & - & + & Anaeróbia & Brenner et al. (2005) \\
\hline Desulfovirga & - & + & Anaeróbia estrita & Brenner et al. (2005) \\
\hline Gemmatimonas & - & + & Aeróbia & Krieg et al. (2010) \\
\hline Geobacter & - & + & Anaeróbia estrita & Brenner et al. (2005) \\
\hline Holophaga & - & + & Anaeróbia & Krieg et al. (2010) \\
\hline Hydrogenophaga & - & + & Aeróbia & Brenner et al. (2005) \\
\hline Methylibium & - & + & Aeróbia & Nakatsu et al. (2006) \\
\hline Oxobacter & - & + & Anaeróbia estrita & Vos et al. (2009) \\
\hline Parvibaculum & & + & Aeróbia & Schleheck et al. (2004b) \\
\hline Pigmentiphaga & - & + & Aeróbia & Brenner et al. (2005) \\
\hline Pseudolabrys & - & + & Aeróbia & Kämpfer et al. (2006) \\
\hline Pseudomonas & - & + & Aeróbia & Brenner et al. (2005) \\
\hline Rhodanobacter & + & + & Aeróbia & Brenner et al. (2005) \\
\hline Rhodopseudomonas & - & + & Aeróbia/anaeróbia & Brenner et al. (2005) \\
\hline Sedimentibacter & - & + & Anaeróbia estrita & Vos et al. (2009) \\
\hline Soehngenia & - & + & Anaeróbia e aerotolerante & Vos et al. (2009) \\
\hline Sporomusa & - & + & Anaeróbia e aerotolerante & Vos et al. (2009) \\
\hline Stenotrophomonas & - & + & Aeróbia & Brenner et al. (2005) \\
\hline Synergistes & - & - & Anaeróbia & Allison et al. (1992) \\
\hline Syntrophomonas & - & + & Anaeróbia & Vos et al. (2009) \\
\hline Variovorax & - & + & Aeróbia & Brenner et al. (2005) \\
\hline Zoogloea & - & + & Aeróbia & Brenner et al. (2005) \\
\hline
\end{tabular}

Na manta de lodo, observou-se abundância relativa entre 13 e $16 \%$ de gêneros relacionados com a degradação de LAS, sendo que cerca de $10 \%$ da abundância relativa correspondeu a gêneros anaeróbios e, em torno de 3-5\%, correspondeu a gêneros aeróbios (Tabela 5.32 e Figura 5.69). 


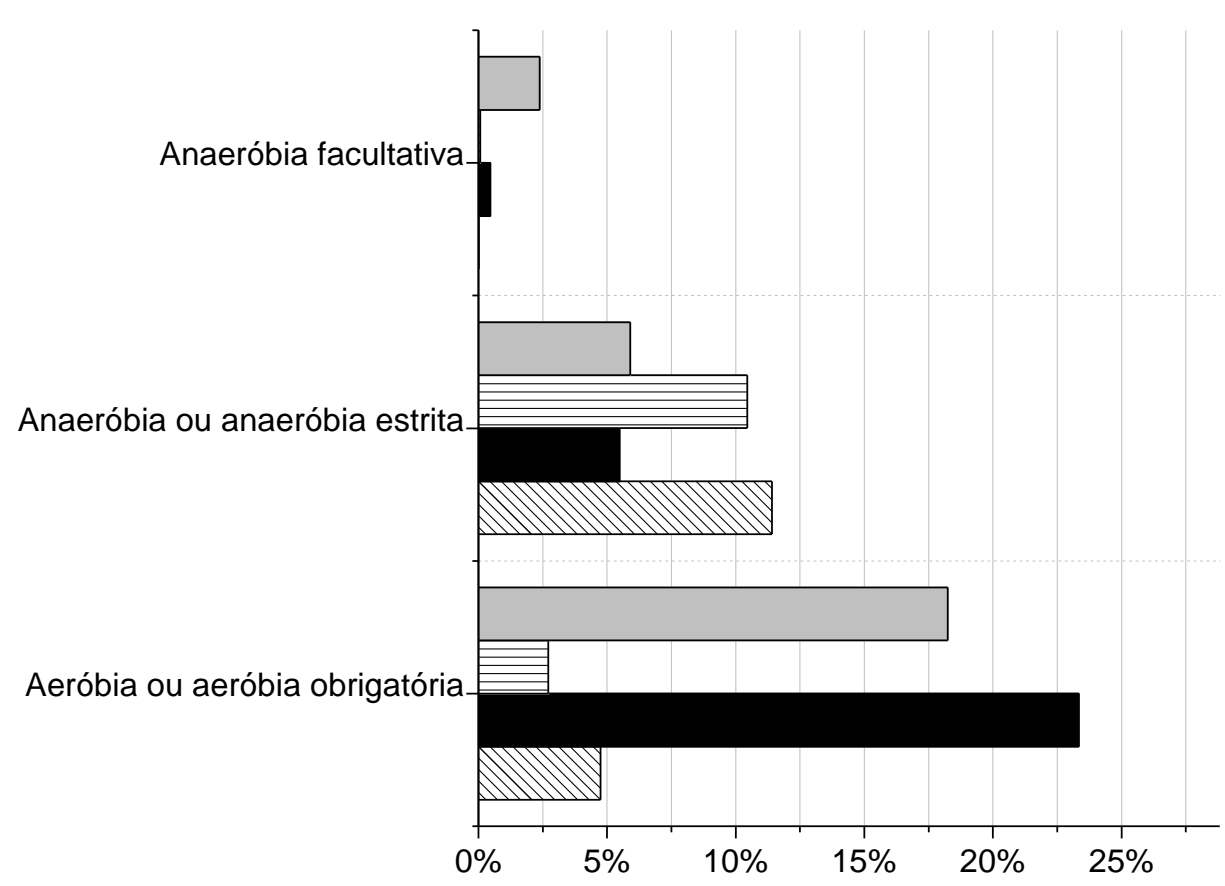

Figura 5.69: Condição dos gêneros relacionados com a degradação de LAS, segundo a soma de abundâncias relativas nas amostras da manta de lodo $(\mathbb{Q})$ e biomassa do separador de fases ( $\square)$ do reator $R_{\mathrm{L} 1}$, e da manta de lodo (目) e biomassa do separador de fases $(\square)$ do reator $R_{\mathrm{S} 1}$

Tabela 5.32: Abundância relativa de gêneros relacionados com a degradação de compostos aromáticos, dessulfonação, $\beta$ e $\omega$-oxidação

\begin{tabular}{lcccc}
\hline & $\begin{array}{c}\text { ML-R } \\
\text { L1 }\end{array}$ & $\begin{array}{c}\text { SF-R } \\
\text { L1 }\end{array}$ & $\begin{array}{c}\text { ML-R } 1 \\
(\%)\end{array}$ & $\begin{array}{c}\text { SF-R } \\
(\%)\end{array}$ \\
\hline $\begin{array}{l}\text { Degradação de composto com um anel aromático } \\
\text { (fenol, tolueno, benzaldeído, hidroxi-, metoxi- e }\end{array}$ & 14,10 & 29,28 & 7,66 & 25,18 \\
benzoatos) & & & & \\
$\begin{array}{l}\text { Dessulfonação } \\
\text { 3-oxidação }\end{array}$ & 8,30 & 1,83 & 2,94 & 8,62 \\
$\omega$-oxidação & 5,47 & 0,18 & 7,86 & 4,77 \\
Total & 3,40 & 0,18 & 2,32 & 4,67 \\
\hline
\end{tabular}

Dentre os gêneros classificados e relacionados com a degradação de LAS, observou-se que a maioria foi encontrada nas amostras da biomassa do separador de fases dos dois reatores (abundância relativa: 27-29\%; Tabela 5.32). A maioria dos gêneros na biomassa do separador de fases foi relacionada com a degradação de compostos com um anel aromático (fenol, tolueno, benzaldeído, hidroxi-, metoxi- e benzoatos), sendo observadas abundâncias relativas de 29 e $25 \%$ nos reatores $R_{\mathrm{L} 1}$ e $\mathrm{R}_{\mathrm{S} 1}$, respectivamente. A maior abundância relativa de gêneros 
relacionados com a degradação de LAS no separador de fases corroborou a maior remoção de surfactante no separador de fases dos dois reatores (55-90\%, p. 116).

A comunidade microbiana da biomassa do separador de fases do reator $\mathrm{R}_{\mathrm{L} 1}$ destacouse pela alta eficiência de remoção de LAS (90\%) nessa região, acompanhado do aumento da concentração de ácidos orgânicos voláteis (de $8 \mathrm{mg} \mathrm{HAc/L}$ para 42 mg HAc/L, p. 115), indicando biotransformação do surfactante. Na biomassa do separador de fases do reator $\mathrm{R}_{\mathrm{L} 1}$, foram encontrados os seguintes gêneros, com significativa abundância relativa $(>0,2 \%)$ : Zoogloea (21\%), Holophaga (4,5\%), Gemmatimonas (1,3\%), Desulfovibrio (0,9\%), Dechloromonas (0,5\%), Hydrogenophaga (0,4\%), Comamonas $\quad(0,3 \%) \quad$ e Pseudomonas (0,2\%).

A condição anaeróbia facultativa do separador de fases foi fundamental para a alta remoção de LAS observada (55-90\%), em virtude dos gêneros aeróbios e anaeróbios encontrados nessa região. Entre os gêneros relacionados com a degradação de LAS, foram encontrados gêneros aeróbios ou aeróbios obrigatórios (abundância relativa: 18-23\%), anaeróbios ou anaeróbios estritos (abundância relativa em torno de 6\%) e gêneros anaeróbios facultativos (abundância relativa: 0,5-2,4\%) (Figura 5.69). Além disso, a presença de oxigênio é necessária para reação de $\omega$-oxidação (início da quebra da cadeia alquílica do LAS), nos dois gêneros encontrados no presente estudo (Tabela 5.30 e Tabela 5.31). As demais reações podem ocorrer em condição aeróbia ou anaeróbia: (i) degradação de compostos aromáticos (13 gêneros aeróbios, 11 anaeróbios, 4 anaeróbios facultativos e um gênero sendo anaeróbio ou aeróbio); (ii) dessulfonação (4 gêneros aeróbios, 2 anaeróbios e um anaeróbio facultativo); e (iii) $\beta$-oxidação (2 gêneros aeróbios; 3 gêneros anaeróbios) (Tabela 5.29, Tabela 5.30 e Tabela 5.31). Dessa forma, algumas das reações envolvidas na degradação de LAS requerem condição aeróbia ( $\omega$-oxidação), enquanto, outras podem ocorrer em condição aeróbia ou anaeróbia (degradação de compostos aromáticos, dessulfonação, $\beta$-oxidação). 
Observou-se temperatura ótima de crescimento em torno de $30^{\circ} \mathrm{C}$ (média: $32 \pm 3^{\circ} \mathrm{C}$ ), em 25 dos gêneros relacionados com a degradação de LAS (Figura 5.70), e pH ótimo em

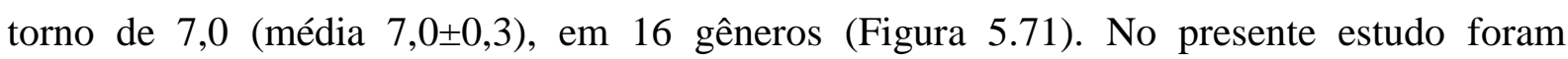
aplicados temperaturas e pH próximos aos valores ótimos de crescimento desses gêneros $\left(30^{\circ} \mathrm{C}\right.$ e pH 8,2; Tabela 5.12, p. 107). Além disso, Abboud et al. (2007) obtiveram maior degradação de LAS em valores similares de temperatura $\left(30\right.$ e $\left.37^{\circ} \mathrm{C}\right)$ e $\mathrm{pH}(8,5)$.

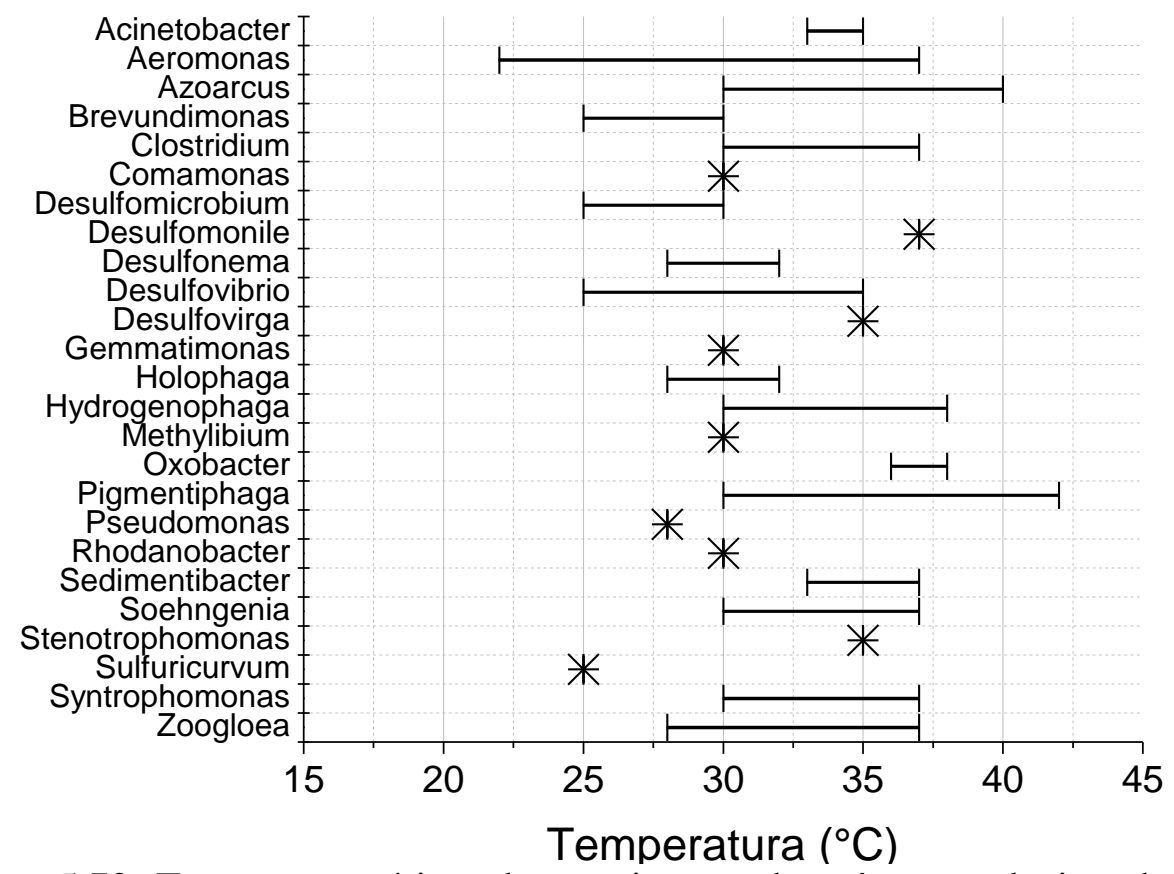

Figura 5.70: Temperatura ótima de crescimento dos gêneros relacionados com a degradação de LAS 


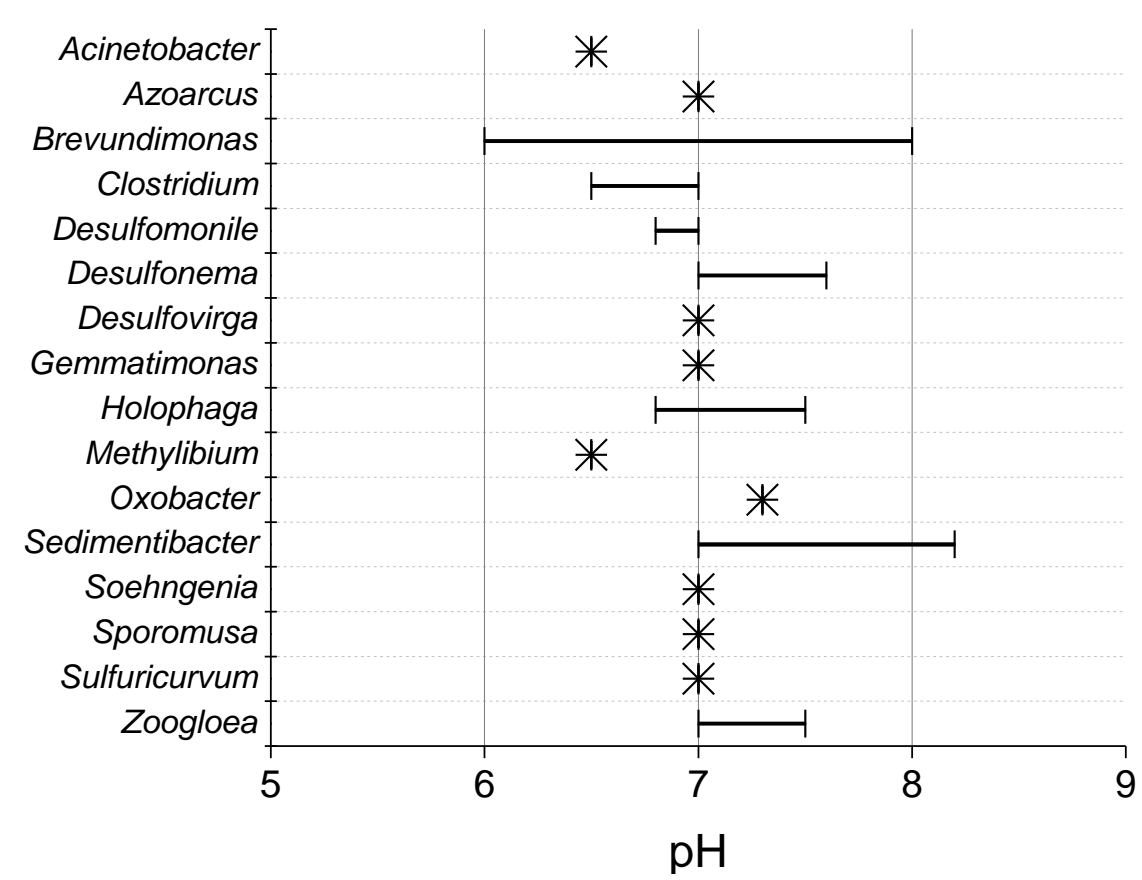

Figura 5.71: pH ótimo de crescimento dos gêneros relacionados com a degradação de LAS

Dentre os gêneros classificados e relacionados com a degradação de LAS, destacaramse 11 cuja abundância relativa foi maior que 1\% (Figura 5.72), os quais foram descritos abaixo:

- Zoogloea: apresentou a maior abundância relativa, de $21 \%$ na biomassa do separador de fases do reator $\mathrm{R}_{\mathrm{L} 1}, 2 \%$ no separador de fases do reator $\mathrm{R}_{\mathrm{S} 1}$, e menos de $0,4 \%$ nas demais amostras. Filo Proteobacteria, Classe Betaproteobacteria, Família Rhodocyclaceae. Gram negativo; aeróbio, usa oxigênio ou nitrato como aceptor final de elétrons. Alguns grupos podem sobreviver em condição anaeróbia, mas não são capazes de crescer. Bacilos embebidos em matriz gelatinosa em formato de árvore ou dedos (BRENNER et al., 2005) - essas morfologias foram observadas em microscopia de contraste de fase da biomassa do separador de fases do reator $\mathrm{R}_{\mathrm{L} 1}$, todavia, não foi possível o registro devido a problemas no equipamento de captura de imagem. Possui espécies capazes de degradar benzoatos, por meta clivagem do anel aromático, além de fenol e tolueno (UNZ e FARRAH, 1972; ARVIN et al., 1989; BRENNER et al., 2005). 


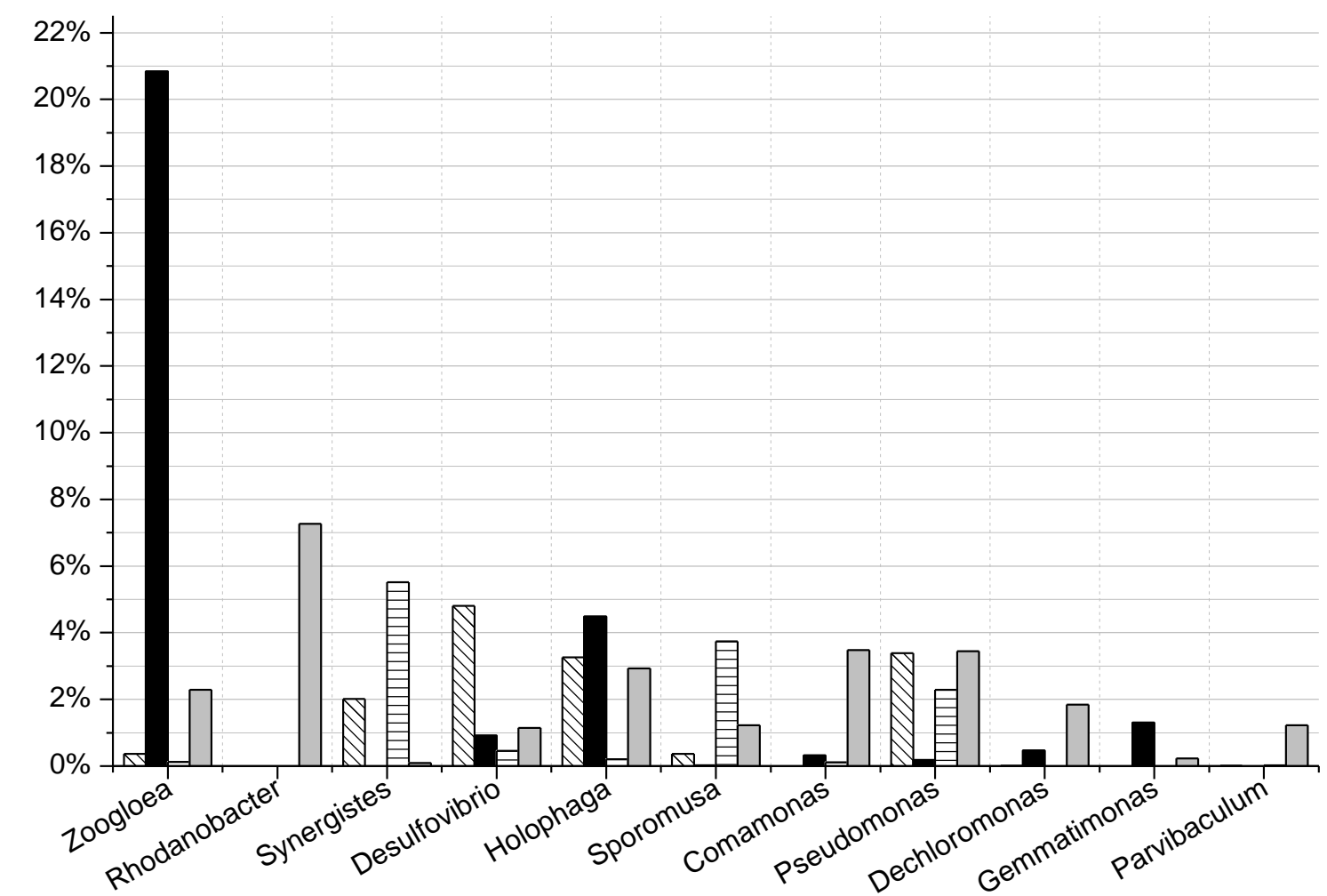

Figura 5.72: Abundância relativa de gêneros relacionados com a degradação de LAS nas amostras da manta de lodo $(\mathbb{\nabla})$ e biomassa do separador de fases $(\boldsymbol{\square})$ do reator $R_{L 1}$, e da manta de lodo (目) e biomassa do separador de fases $(\square)$ do reator $\mathrm{R}_{\mathrm{S} 1}$

- Rhodanobacter: observou-se abundância relativa de 7\% na biomassa do separador de fases do reator $\mathrm{R}_{\mathrm{S} 1}$. Filo Proteobacteria, Classe Gammaproteobacteria, Família Xanthomonadaceae. Anaeróbio; bacilos; gram negativo (BRENNER et al., 2005). $R$. xiangquanii pode usar hidroxibenzoatos (ZHANG et al., 2011);

- Synergistes: abundância relativa de 2 e 5,5\% na manta de lodo dos reatores $\mathrm{R}_{\mathrm{L} 1}$ e $\mathrm{R}_{\mathrm{S} 1}$, respectivamente. Filo Synergistetes, Classe Synergistia, Família Synergistaceae. Anaeróbio; bacilo; gram negativo. Possui espécies capazes de degradar DHP (dihidroxipiridina) e realizar reações de $\beta$-oxidação (ALLISON et al., 1992; KUMAR et al., 2010)

- Desulfovibrio: abundância relativa de $5 \%$ na manta de lodo do reator $\mathrm{R}_{\mathrm{L} 1}$ e menos de $1 \%$ nas demais amostras (Figura 5.72). Filo Proteobacteria, Classe 
Deltaproteobacteria, Família Desulfovibrionaceae. Bacilos curvos (eventualmente bacilos retos); gram negativo; anaeróbio, usando sulfato ou outros compostos de enxofre como aceptores finais de elétrons (BRENNER et al., 2005). Possui espécies capazes de reação de dessulfonação, consumir benzaldeído e trihidroxibenzenos (ZELLNER et al., 1989; ZELLNER et al., 1990; REICHENBECHER e SCHINK, 1997; COOK et al., 1998). Culturas puras de D. desulfuricans foram capazes de reduzir compostos sulfonados usando lactato como doador de elétrons (LAUE et al., 1997; LIE et al., 1999). A presença de Desulfovibrio na manta de lodo do reator $\mathrm{R}_{\mathrm{L} 1}$ foi relacionada com a capacidade de dessulfonação com lactato como doador de elétrons, em virtude da maior presença de ácido lático na água residuária de lavanderia (cerca de $150 \mathrm{mg} / \mathrm{L}$; item 5.4.1, p. 105).

- Holophoga: abundância relativa entre 3 e 4,5\% na biomassa do separador de fases (reatores $\mathrm{R}_{\mathrm{L} 1}$ e $\mathrm{R}_{\mathrm{S} 1}$ ) e na manta de lodo (reator $\mathrm{R}_{\mathrm{L} 1}$ ) (Figura 5.72). Filo Acidobacteria, Classe Holophagae, Família Holophagaceae. Bacilo; gram negativo; anaeróbio. Fermenta trimetoxibenzoatos e trihidroxibenzenos para acetato (KRIEG et al., 2010);

- Sporomusa: abundância relativa de 3,7\% na manta de lodo do reator $\mathrm{R}_{\mathrm{S} 1}$ e abaixo de $1 \%$ nas demais amostras (Figura 5.72). Filo Firmicutes, Classe Clostridia, Família Veillonellaceae. Anaeróbio; gram negativo; morfologia em forma de banana, flagelada no lado côncavo da célula, formando endósporos. Possui espécies capazes de degradar trimetoxibenzoatos (VOS et al., 2009);

- Comamonas: maior abundância relativa na biomassa do separador de fases do reator $\mathrm{R}_{\mathrm{S} 1}(3,5 \%)$, nas demais amostras observou-se presença abaixo de 0,3\% (Figura 5.72). Filo Proteobacteria, Classe Betaproteobacteria, Família Comamonadaceae. Gram negativo; aeróbio, capaz de desnitrificação; bacilos retos, levemente curvos ou espirilo (BRENNER et al., 2005). Possui espécies capazes de degradar PAH (Polycyclic 
Aromatic Hydrocarbon - Hidrocarboneto aromático policíclico), sulfobenzoatos e clorofenol; algumas espécies são capazes de reações de dessulfonação; e algumas espécies são capazes de usar intermediários da degradação de LAS produzidos pelo gênero Parvibaculum (COOK et al., 1998; SCHLEHECK et al., 2004a; BRENNER et al., 2005; SCHLEHECK et al., 2010);

- Pseudomonas: abundância relativa entre 2,3 e 3,5\% nas amostras da manta de lodo (reatores $\mathrm{R}_{\mathrm{L} 1}$ e $\mathrm{R}_{\mathrm{S} 1}$ ) e na biomassa do separador de fases (reator $\mathrm{R}_{\mathrm{S} 1}$ ) (Figura 5.72). Filo Proteobacteria, Classe Gammaproteobacteria, Família Pseudomonadaceae. Gram negativo; aeróbio, em alguns casos pode usar nitrato como aceptor de elétrons; bacilos retos ou levemente curvos. Possui espécies capazes de degradar tolueno, benzoato e hidroxibenzoatos, além de espécies capazes de reação de dessulfonação (KERTESZ et al., 1994; COOK et al., 1998; BRENNER et al., 2005). Kertesz et al. (1994) observaram a dessulfonação de LAS por $P$. putida, em condição limitada de sulfato. Além disso, vários estudos com LAS empregaram ou encontraram espécies de Pseudomonas (Tabela 5.29, p. 156);

- Dechloromonas: maior abundância relativa na biomassa do separador de fases do reator $\mathrm{R}_{\mathrm{S} 1}(1,8 \%)$, seguida pelo separador de fases do reator $\mathrm{R}_{\mathrm{L} 1}(0,5 \%)$ e por último a manta de lodo do reator $\mathrm{R}_{\mathrm{L} 1}(0,02 \%)$. Filo Proteobacteria, Classe Betaproteobacteria, Família Rhodocyclaceae. Bacilo; gram negativo; anaeróbio facultativo, reduzindo clorato e perclorato para cloreto (BRENNER et al., 2005). Algumas espécies podem degradar benzeno, tolueno e etilbenzeno (CHAKRABORTY et al., 2005);

- Gemmatimonas: presença detectada na biomassa do separador de fases dos reatores $\mathrm{R}_{\mathrm{L} 1}(1,3 \%)$ e $\mathrm{R}_{\mathrm{S} 1}(0,2 \%)$. Filo Gemmatimonadetes, Classe Gemmatimonadetes, Família Gemmatimonadaceae. Bacilo; gram negativo; aeróbio. Possui espécie capaz de degradar benzoato (KRIEG et al., 2010); 
- Parvibaculum: maior presença no separador de fases do reator $\mathrm{R}_{\mathrm{S} 1}(1,2 \%)$; na manta de lodo dos reatores $\mathrm{R}_{\mathrm{L} 1}$ e $\mathrm{R}_{\mathrm{S} 1}$ observou-se abundância relativa de $0,2 \%$. Filo Proteobacteria, Classe Alphaproteobacteria, Família Rhodobiaceae. Bacilo; gram negativo; aeróbio. Caracteriza-se por iniciar catabolismo de LAS, sendo capaz de reações de $\beta$ e $\omega$-oxidação (SCHLEHECK et al., 2004b).

Além dos gêneros supracitados, outros seis possuem membros capazes de degradar outros compostos aromáticos (carbazol, fenilalanina, naftil fosfato, PAH e PCP), sendo dois gêneros encontrados em estudos com LAS (Flavobacterium e Phenylobacterium) (Tabela 5.33). As abundâncias relativas dos gêneros relacionados com a degradação de LAS e outros compostos aromáticos encontram-se na Tabela 5.34. No apêndice A, encontram-se listados todos os gêneros classificados, com respectivas abundâncias relativas.

Tabela 5.33: Gêneros relacionados com a degradação de outros compostos aromáticos, relacionados com a presença em estudos com LAS (ref. em negrito)

\begin{tabular}{|c|c|c|c|}
\hline Gênero & $\begin{array}{l}\text { Composto } \\
\text { aromático }\end{array}$ & $\begin{array}{l}\text { Presença } \\
\text { em LAS }\end{array}$ & Referências \\
\hline Chelatococcus & Fenilalanina & - & Brenner et al. (2005) \\
\hline Ferruginibacter & Naftil fosfato & - & Lim et al. (2009) \\
\hline Flavobacterium & PCP & + & $\begin{array}{l}\text { Steiert et al. (1987); Topp et al. (1988); Duarte et } \\
\text { al. (2010a); Krieg et al. (2010) }\end{array}$ \\
\hline Oceanibaculum & $\mathrm{PAH}$ & - & Lai et al. (2009); Balcázar et al. (2012) \\
\hline Phenylobacterium & Fenilalanina & + & $\begin{array}{l}\text { Brenner et al. (2005); Sanchez-Peinado et al. } \\
\text { (2010) }\end{array}$ \\
\hline Sphingosinicella & Carbazol & - & Maruyama et al. (2006) \\
\hline
\end{tabular}


Tabela 5.34: Abundância relativa de gêneros relacionados com a degradação de LAS e outros compostos aromáticos

\begin{tabular}{|c|c|c|c|c|}
\hline Gênero & $\mathrm{ML}-\mathrm{R}_{\mathrm{L} 1}(\%)$ & SF-R ${ }_{\mathrm{L} 1}(\%)$ & ${\mathrm{ML}-\mathrm{R}_{\mathrm{S} 1}(\%)}$ & SF-R ${ }_{\mathrm{S} 1}(\%)$ \\
\hline Acinetobacter & 0,06 & - & - & - \\
\hline Aeromonas & - & - & 0,07 & 0,55 \\
\hline Azoarcus & - & - & - & 0,02 \\
\hline Brevundimonas & 0,89 & 0,07 & - & - \\
\hline Chelatococcus & 0,06 & 0,23 & 0,01 & - \\
\hline Clostridium & 0,03 & 0,02 & 0,01 & - \\
\hline Comamonas & - & 0,32 & 0,11 & 3,48 \\
\hline Dechloromonas & 0,02 & 0,47 & - & 1,84 \\
\hline Desulfomicrobium & 0,48 & 0,04 & 0,05 & - \\
\hline Desulfomonile & 0,08 & - & - & - \\
\hline Desulfonema & 0,15 & - & 0,09 & - \\
\hline Desulfovibrio & 4,81 & 0,91 & 0,46 & 1,14 \\
\hline Desulfovirga & 0,03 & - & 0,01 & - \\
\hline Ferruginibacter & - & 0,97 & - & 1,03 \\
\hline Flavobacterium & - & - & 0,02 & 0,48 \\
\hline Gemmatimonas & - & 1,31 & - & 0,23 \\
\hline Geobacter & 0,05 & 0,02 & 0,02 & 0,02 \\
\hline Holophaga & 3,27 & 4,48 & 0,21 & 2,93 \\
\hline Hydrogenophaga & 0,02 & 0,39 & - & - \\
\hline Methylibium & - & 0,04 & - & - \\
\hline Oceanibaculum & - & - & - & 0,02 \\
\hline Oxobacter & 0,12 & - & 0,10 & - \\
\hline Parvibaculum & 0,02 & - & 0,02 & 1,23 \\
\hline Phenylobacterium & 0,08 & 1,85 & 0,07 & 1,31 \\
\hline Pigmentiphaga & - & 0,04 & - & 0,02 \\
\hline Pseudolabrys & - & 0,07 & - & 0,02 \\
\hline Pseudomonas & 3,39 & 0,18 & 2,29 & 3,45 \\
\hline Rhodanobacter & - & - & - & 7,27 \\
\hline Rhodopseudomonas & - & - & - & 0,02 \\
\hline Sedimentibacter & - & - & 0,01 & - \\
\hline Soehngenia & - & - & 0,21 & 0,45 \\
\hline Sphingosinicella & - & 0,02 & - & - \\
\hline Sporomusa & 0,37 & 0,02 & 3,74 & 1,23 \\
\hline Stenotrophomonas & - & - & 0,16 & 0,24 \\
\hline Synergistes & 2,02 & - & 5,52 & 0,10 \\
\hline Syntrophomonas & 0,02 & - & 0,01 & - \\
\hline Variovorax & - & 0,07 & - & - \\
\hline Zoogloea & 0,37 & 20,84 & 0,12 & 2,29 \\
\hline
\end{tabular}




\subsubsection{Considerações}

Na Parte 1 do ensaio, avaliando a degradação de $10 \mathrm{mg} / \mathrm{L}$ de LAS em reatores com água residuária de lavanderia $\left(\mathrm{R}_{\mathrm{L} 1}\right)$ e água residuária sintética $\left(\mathrm{R}_{\mathrm{S} 1}\right)$, observou-se maior eficiência no reator $\mathrm{R}_{\mathrm{L} 1}(82 \%)$ que no reator $\mathrm{R}_{\mathrm{S} 1}(45 \%)$. Atribuiu-se a alta degradação no reator $\mathrm{R}_{\mathrm{L} 1}$ à variedade de co-substratos da água residuária de lavanderia (12 ácidos orgânicos voláteis detectados) e a baixa concentração de co-substratos (COE de 0,03 g DQO/g STV.d equivalente à parcela de ácidos orgânicos voláteis).

Na Parte 2 do ensaio, avaliando a degradação de 10-20 mg/L de LAS em reator com água residuária de lavanderia $\left(\mathrm{R}_{\mathrm{L} 2}\right)$ e de $10 \mathrm{mg} / \mathrm{L}$ de $\mathrm{LAS}$ em reator com água residuária sintética $\left(\mathrm{R}_{\mathrm{S} 2}\right)$ com menor concentração de cloreto de amônio $(20 \mathrm{mg} / \mathrm{L})$, verificou-se menor eficiência em ambos os reatores $\left(\mathrm{R}_{\mathrm{L} 2}: 58 \% ; \mathrm{R}_{\mathrm{S} 2}: 27 \%\right)$. No reator $\mathrm{R}_{\mathrm{L} 2}$, verificou-se menor degradação de LAS (58\%) com o aumento da concentração afluente de surfactante (média: $13 \pm 5 \mathrm{mg} / \mathrm{L}$ ), devido ao aumento do potencial de inibição na presença de maiores concentrações de LAS. Atribuiu-se a menor degradação de LAS no reator $\mathrm{R}_{\mathrm{S} 2}(27 \%)$ à redução das fontes de nitrogênio (redução de $\mathrm{NH}_{4} \mathrm{Cl}$ de $1.000 \mathrm{mg} / \mathrm{L}$ para $20 \mathrm{mg} / \mathrm{L}$ ), uma vez que a suplementação de fontes de nitrogênio é necessária para a degradação de LAS.

Em virtude da maior eficiência de degradação de LAS, realizou-se análise de pirosequenciamento de amostras coletadas nos reatores da Parte 1. Com relação à comunidade microbiana dos reatores da Parte 1, observou-se maior riqueza nas amostras da manta de lodo que na biomassa do separador de fases, em virtude da proteção proporcionada pela estrutura de grânulo da manta de lodo. Devido à variedade de ácidos orgânicos voláteis detectados na água residuária de lavanderia, verificou-se maior riqueza na manta de lodo do reator $\mathrm{R}_{\mathrm{L} 1}$ (água residuária de lavanderia) que na manta de lodo do reator $\mathrm{R}_{\mathrm{S} 1}$ (água residuária sintética). 
Os gêneros classificados corresponderam à abundância relativa em torno de 28-39\% em cada amostra, com exceção da amostra da biomassa do separador de fases do reator $\mathrm{R}_{\mathrm{S} 1}$, na qual a abundância relativa de gêneros classificados foi de $77 \%$. Ao todo, foram encontrados 147 gêneros, dos quais 32 foram relacionados com a degradação de LAS. Dentre os gêneros classificados e relacionados com a degradação de LAS, a maioria (27) possui espécies capazes de degradar compostos com um anel aromático (fenol, tolueno, benzaldeído, hidroxi-, metoxi- e benzoatos); sete gêneros são capazes de reação de dessulfonação; cinco gêneros são capazes de $\beta$-oxidação; e dois gêneros são capazes de $\omega$-oxidação.

Em virtude da maior abundância relativa na biomassa do separador de fases (região com maior remoção de LAS: 55-90\%), destacou-se a presença dos gêneros Zoogloea (21\%) e Rhodanobacter (7\%), na biomassa do separador de fases dos reatores $R_{L 1}$ e $R_{S 1}$, respectivamente. Na manta de lodo do reator $\mathrm{R}_{\mathrm{L} 1}$, encontrou-se o gênero Desulfovibrio relacionado com capacidade de algumas espécies realizarem dessulfonação usando lactato (disponível na água residuária de lavanderia) como doador de elétrons.

Além disso, observou-se alta abundância relativa (34\%) para o gênero Nitrosomonas na biomassa do separador de fases do reator $\mathrm{R}_{\mathrm{S} 1}$. Nitrosomonas realiza oxidação do amônio, que era fornecido em alta quantidade pela água residuária sintética $(1.000 \mathrm{mg} / \mathrm{L}$ de cloreto de amônio no reator $\mathrm{R}_{\mathrm{S} 1}$ ).

Apesar da maior riqueza das amostras da manta de lodo, a maioria dos gêneros classificados e relacionados com a degradação de LAS encontrava-se na biomassa do separador de fases dos reatores $\mathrm{R}_{\mathrm{L} 1}$ e $\mathrm{R}_{\mathrm{S} 1}$ (abundância relativa de 29 e $27 \%$, respectivamente). A maior abundância relativa de gêneros relacionados com a degradação de LAS na biomassa do separador de fases corroborou a remoção de surfactante observada nessa região (55-90\%). Na manta de lodo, observou-se abundância relativa de $16 \%\left(\mathrm{R}_{\mathrm{L} 1}\right)$ e $13 \%\left(\mathrm{R}_{\mathrm{S} 1}\right)$ de gêneros 
relacionados com a degradação de LAS, sendo observada remoção de surfactante apenas no reator com água residuária sintética $\left(\mathrm{R}_{\mathrm{S} 1}\right.$ : cerca de $\left.20 \%\right)$.

Na biomassa do separador de fases, destacou-se a abundância relativa de gêneros aeróbios (18-23\%) e anaeróbios (6\%), relacionados com a degradação de LAS. A presença de gêneros aeróbios e anaeróbios relacionados com a degradação de LAS evidenciou a relação entre a condição anaeróbia facultativa do separador de fases e a remoção de surfactante observada nessa região. A condição anaeróbia facultativa do separador de fases foi fundamental para a remoção de LAS, uma vez que os dois gêneros capazes de $\omega$-oxidação (reação que inicia a quebra da cadeia alquílica) são aeróbios, enquanto, as demais reações (dessulfonação, $\beta$-oxidação e degradação de compostos aromáticos) podem ocorrer nas condições anaeróbia e aeróbia. 


\section{CONCLUSÕES}

Verificou-se menor adsorção de LAS ao lodo granulado à medida que os sítios de adsorção foram preenchidos. O equilíbrio entre adsorção e degradação de LAS requeriu menor tempo em duas situações: pelo aumento de TDH; e pelo decréscimo da concentração de sólidos totais.

A remoção de LAS foi maior na presença de co-substrato complexo (50\%; extrato de levedura) que na presença de alcoóis de cadeia curta (29-31\%; metanol e etanol). Todavia, em virtude da estrutura de grânulo da manta de lodo, verificou-se, por meio de análise de FISH, variação pouco significativa entre as comunidades do domínio Archaea e Bacteria na presença de diferentes co-substratos (metanol, etanol e extrato de levedura).

A aeração da água de abastecimento provocou redução da comunidade do domínio Archaea, de 60\% para 55\% (obtido por análise de FISH). Após cerca de 90 dias, observou-se a recuperação da comunidade do domínio Archaea (aumento para 60\%). Atribuiu-se a recuperação do reator UASB à retirada do excesso de ácidos orgânicos voláteis; o tamponamento com bicarbonato de sódio; e a redução da concentração DQO, para controle da produção de ácidos orgânicos voláteis.

A comparação entre a variação de biodisponibilidade de LAS, TDH e concentração de co-substratos, evidenciou a maior influência da concentração de co-substratos na degradação de LAS, seguido pelo TDH e por último a biodisponibilidade de LAS. 
Verificou-se maior degradação de LAS à medida que se aplicou menor concentração de co-substratos (carga orgânica específica), sendo observada eficiência de degradação de 76\% para carga orgânica específica de 0,03 g DQO/g STV.d.

Considerando as eficiências de degradação de LAS observadas em TDH de 6 h (18\%), 35 h (entre 37 e $53 \%$ ) e 80 h (55\%), verificou-se equilíbrio entre o tempo necessário para as reações de degradação de LAS e a taxa de surfactante aplicado no TDH de 35 h.

O aumento da biodisponibilidade de LAS, mediante decréscimo da concentração de biomassa (16-1,3 g ST/L), resultou em discreto aumento da degradação de LAS (de 37\% para $53 \%)$

Por meio da técnica de PCR-DGGE, observou-se maior coeficiente de similaridade (Archaea: 70-90\%; Bacteria: 69-83\%) na manta de lodo dos reatores variando a biodisponibilidade de LAS, TDH e concentração de co-substratos. Em virtude da maior exposição da comunidade microbiana às condições experimentais, verificou-se maior variação dos coeficientes de similaridade nas amostras da biomassa do separador de fases (Archaea: 29-86\%; Bacteria: 52-76\%). Apesar disso, obteve-se maior remoção de LAS no separador de fases (20-53\%), sendo essa eficiência relacionada com a menor concentração de co-substratos (ácidos orgânicos voláteis) e condição anaeróbia facultativa nessa região.

Com relação à água residuária de lavanderia, obteve-se alta eficiência de degradação de LAS (82\%) com água de lavanderia diluída para concentração de surfactante de 10 mg/L. A eficiência de degradação de LAS foi menor (58\%) ao se aplicar água de lavanderia diluída com concentração de LAS variando entre 6 e $21 \mathrm{mg} / \mathrm{L}$ (média: $13 \pm 5 \mathrm{mg} / \mathrm{L}$ ). A degradação de LAS foi favorecida pela variedade de co-substratos (ácidos orgânicos voláteis) presentes na água residuária de lavanderia e pela baixa concentração desses co-substratos nos reatores.

Realizou-se análise de pirosequenciamento de amostras dos reatores alimentados com água residuária de lavanderia $\left(\mathrm{R}_{\mathrm{L} 1}\right)$, cuja eficiência de degradação de LAS foi a maior $(82 \%)$, 
e com água residuária sintética $\left(\mathrm{R}_{\mathrm{S} 1}\right)$, cuja eficiência de degradação foi de $45 \%$. Foram encontrados 147 gêneros, dos quais 32 gêneros foram relacionados com a degradação de LAS. Vinte e nove gêneros são capazes de degradar compostos com um anel aromático (fenol, tolueno, benzaldeído, hidroxi-, metoxi- e benzoatos), dos quais nove se destacaram pela abundância relativa (maior que 1\%): Comamonas, Dechloromonas, Desulfovibrio, Gemmatimonas, Holophaga, Pseudomonas, Rhodanobacter, Sporomusa e Zoogloea. Sete gêneros são capazes de dessulfonação: Acinetobacter, Aeromonas, Clostridium, Comamonas, Desulfovibrio, Hydrogenophaga e Pseudomonas. Cinco gêneros são capazes de $\beta$-oxidação: Desulfovirga, Parvibaculum, Pseudomonas, Synergistes e Syntrophomonas. Dois gêneros são capazes de $\omega$-oxidação: Parvibaculum e Pseudomonas.

O gênero Zoogloea apresentou significativa abundância relativa na biomassa do separador de fases do reator com água residuária de lavanderia (21\%); de condição aeróbia, pode usar oxigênio ou nitrato como aceptor de elétrons, além de degradar compostos aromáticos.

Na manta de lodo do reator com água residuária de lavanderia identificou-se o gênero Desulfovibrio (abundância relativa de 5\%), relacionado com a degradação de compostos aromáticos e dessulfonação combinada com lactato (presente na água residuária de lavanderia).

$\mathrm{Na}$ biomassa do separador de fases do reator com água residuária sintética, foi encontrado o gênero Rhodanobacter (abundância relativa de 7\%); de condição anaeróbia, uma espécie, $R$. xiangquanii, pode usar hidroxibenzoatos. O gênero Nitrosomonas é de condição aeróbia e realiza oxidação de amônio; sua alta abundância relativa (34\%) na biomassa do separador de fases do reator com água residuária sintética atribuiu-se à alta concentração de amônio da água residuária $\left(\mathrm{NH}_{4} \mathrm{Cl}: 1.000 \mathrm{mg} / \mathrm{L}\right)$. 
$\mathrm{Na}$ manta de lodo, observou-se abundância relativa de 13-16\% de gêneros relacionados com a degradação de LAS. No separador de fases, a maior abundância relativa (27-29\%) de gêneros relacionados com a degradação de LAS corroborou a remoção de surfactante nessa região (55-90\%). No separador de fases foram encontrados gêneros aeróbios (abundância relativa: 18-23\%) e anaeróbios (abundância relativa: 6\%) relacionados com a degradação de LAS. A condição anaeróbia facultativa foi fundamental para o início da quebra da cadeia alquílica do LAS, uma vez que os dois gêneros capazes de $\omega$-oxidação são aeróbios, enquanto as demais reações ( $\beta$-oxidação, dessulfonação, degradação de compostos aromáticos) podem ocorrer, tanto em condição aeróbia, quanto em condição anaeróbia. 


\section{SUGESTÕES}

- Monitoramento temporal das concentrações de LAS no ponto de amostragem anterior à região do separador de fases, além das medidas afluente e efluente, para análise de balanço de massa de LAS em cada região do reator (manta de lodo e separador de fases);

- Desenvolvimento de biomassa no separador de fases em condições semelhantes às observadas no reator alimentado com água residuária de lavanderia diluída para concentração de LAS em torno de $10 \mathrm{mg} / \mathrm{L}$. Essa biomassa poderia ser utilizada como inóculo em outro reator, avaliando a degradação de LAS em condição aeróbia (ou com aeração intermitente), anaeróbia e anaeróbia facultativa;

- Avaliação de materiais suporte para aumentar o tempo de retenção celular da biomassa do separador de fases;

- Aplicação da técnica de reação de polimerização em cadeia em tempo real (polymerase chain reaction real time: PCR real time) para quantificação de grupos microbianos relacionados com a degradação de LAS, sendo selecionados esses grupos com base nos resultados de pirosequenciamento. 


\section{REFERÊNCIAS BIBLIOGRÁFICAS}

ABBASI, T.; ABBASI, S. A. Formation and impact of granules in fostering clean energy production and wastewater treatment in upflow anaerobic sludge blanket (UASB) reactors. Renewable and Sustainable Energy Reviews, v. 16, n. 3, p. 1696-1708, 2012.

ABBOUD, M. M.; KHLEIFAT, K. M.; BATARSEH, M.; TARAWNEH, K. A.; ALMUSTAFA, A.; AL-MADADHAH, M. Different optimization conditions required for enhancing the biodegradation of linear alkylbenzosulfonate and sodium dodecyl sulfate surfactants by novel consortium of Acinetobacter calcoaceticus and Pantoea agglomerans. Enzyme and Microbial Technology, v. 41, n. 4, Sep, p. 432-439, 2007.

ABE, D. S. Desnitrificação e caracterização filogenética das bactérias de vida livre e bactérias aderidas às partículas no hipolímio do lago Kizaki, Japão. Tese (Doutorado). Escola de Engenharia de São Carlos, Universidade de São Paulo. São Carlos, 1998.

ACHENBACH, L. A.; MICHAELIDOU, U.; BRUCE, R. A.; FRYMAN, J.; COATES, J. D. Dechloromonas agitata gen. nov., sp nov and Dechlorosoma suillum gen. nov., sp nov., two novel environmentally dominant (per)chlorate-reducing bacteria and their phylogenetic position. International Journal of Systematic and Evolutionary Microbiology, v. 51, Mar, p. 527-533, 2001.

ADEEL, Z.; LUTHY, R. Sorption and transport kinetics of a non-ionic surfactant through an aquifer sediment. Environment Science Technology, v. 29, p. 1032-1042, 1995.

ADRIANO, D. C. Trace Elements in Terrestrial Environments: Biogeochemistry, Bioavailability, and Risks of Metals. 2. ed. New York: Springer, 2001

AHN, Y. H. Sustainable nitrogen elimination biotechnologies: A review. Process Biochemistry, v. 41, n. 8, Aug, p. 1709-1721, 2006.

ALBUQUERQUE, L.; SANTOS, J.; TRAVASSOS, P.; NOBRE, M. F.; RAINEY, F. A.; WAIT, R.; EMPADINHAS, N.; SILVA, M. T.; COSTA, M. S. Albidovulum inexpectatum gen. nov., sp nov., a nonphotosynthetic and slightly thermophilic bacterium from a marine hot spring that is very closely related to members of the photosynthetic genus Rhodovulum. Applied and Environmental Microbiology, v. 68, n. 9, Sep, p. 4266-4273, 2002.

ALLISON, M. J.; MAYBERRY, W. R.; MCSWEENEY, C. S.; STAHL, D. A. Synergistes jonesii, gen. nov., sp.nov.: A Rumen Bacterium That Degrades Toxic Pyridinediols. Systematic and Applied Microbiology, v. 15, n. 4, p. 522-529, 1992.

ALMENDARIZ, F. J.; MERAZ, M.; SOBERON, G.; MONROY, O. Degradation of linear alkylbenzene sulphonate (LAS) in an acidogenic reactor bioaugmented with a Pseudomonas aeruginosa (M113) strain. Water Science and Technology, v. 44, n. 4, p. 183-188, 2001. 
ALPHENAAR, P. A.; VISSER, A.; LETTINGA, G. The effect of liquid upward velocity and hydraulic retention time on granulation in UASB reactors treating waste-water with a high sulfate content. Bioresource Technology, v. 43, n. 3, p. 249-258, 1993.

AMANN, R. I.; BINDER, B. J.; OLSON, R. J.; CHISHOLM, S. W.; DEVEREUX, R.; STAHL, D. A. Combination of 16s ribosomal-RNA-targeted oligonucleotide probes with flow-cytometry for analyzing mixed microbial-populations. Applied and Environmental Microbiology, v. 56, n. 6, Jun, p. 1919-1925, 1990.

AN, D. S.; IM, W. T.; YANG, H. C.; LEE, S. T. Shinella granuli gen. nov., sp. nov., and proposal of the reclassification of Zoogloea ramigera ATCC 19623 as Shinella zoogloeoides sp. nov. International Journal of Systematic and Evolutionary Microbiology, v. 56, n. 2, February 1, 2006, p. 443-448, 2006.

ANDERS, H. J.; KAETZKE, A.; KÄMPFER, P.; LUDWIG, W.; FUCHS, G. Taxonomic Position of Aromatic-Degrading Denitrifying Pseudomonad Strains K 172 and KB 740 and Their Description as New Members of the Genera Thauera, as Thauera aromatica sp. nov., and Azoarcus, as Azoarcus evansii sp. nov., Respectively, Members of the Beta Subclass of the Proteobacteria. International Journal of Systematic Bacteriology, v. 45, n. 2, April 1, 1995, p. 327-333, 1995.

ANGELIDAKI, I.; PETERSEN, S. P.; AHRING, B. K. Effects of lipids on thermophilic anaerobic-digestion and reduction of lipid inhibition upon addition of bentonite. Applied Microbiology and Biotechnology, v. 33, n. 4, Jul, p. 469-472, 1990.

ANGELIDAKI, I.; TORANG, L.; WAUL, C. M.; SCHMIDT, J. E. Anaerobic bioprocessing of sewage sludge, focusing on degradation of linear alkylbenzene sulfonates (LAS). Water Science and Technology, v. 49, n. 10, Jun 23-25, p. 115-122, 2004.

APHA; AWWA; WPCF. Standard Methods for the Examination of water and wastewater. 21. ed. Washington, DC: American Public Health Association, 2005

ARAÚJO, J. C. Biofilmes anaeróbios: desenvolvimento e caracterização filogenética usando a hibridização in situ com sondas fluorescentes. Tese (Doutorado). Escola de Engenharia de São Carlos, Universidade de São Paulo. São Carlos, 2001.

ARVIN, E.; JENSEN, B. K.; GUNDERSEN, A. T. Substrate interactions during aerobic biodegradation of benzene. Applied and Environmental Microbiology, v. 55, n. 12, Dec, p. 3221-3225, 1989.

BAENA, S.; FARDEAU, M. L.; LABAT, M.; OLLIVIER, B.; THOMAS, P.; GARCIA, J. L.; PATEL, B. K. C. Aminobacterium colombiensegen. nov. sp. nov., an Amino Acid-degrading Anaerobe Isolated from Anaerobic Sludge. Anaerobe, v. 4, n. 5, p. 241-250, 1998.

BAENA, S.; FARDEAU, M. L.; OLLIVIER, B.; LABAT, M.; THOMAS, P.; GARCIA, J. L.; PATEL, B. K. C. Aminomonas paucivorans gen. nov., sp nov., a mesophilic anaerobic, amino-acid-utilizing bacterium. International Journal of Systematic Bacteriology, v. 49, Jul, p. $975-982,1999$. 
BALCÁZAR, J.; PLANAS, M.; PINTADO, J. Oceanibacterium hippocampi gen. nov., sp. nov., isolated from cutaneous mucus of wild seahorses (Hippocampus guttulatus). Antonie van Leeuwenhoek, p. 1-5, 2012.

BASAR, C. A.; KARAGUNDUZ, A.; CAKICI, A.; KESKINLER, B. Removal of surfactants by powered activated carbon and microfiltration. Water Research, v. 38, n. 8, Apr, p. 21172124, 2004.

BEILEN, J. B.; WUBBOLTS, M. G.; WITHOLT, B. Genetics of alkane oxidation by Pseudomonas oleovorans. Biodegradation, v. 5, n. 3, p. 161-174, 1994.

BELTRAN, F. J.; GARCIA-ARAYA, J. F.; ALVAREZ, P. M. Sodium dodecylbenzenesulfonate removal from water and wastewater. 1. Kinetics of decomposition by ozonation. Industrial \& Engineering Chemistry Research, v. 39, n. 7, Jul, p. 2214-2220, 2000.

BOONE, D. R.; BRYANT, M. P. Propionate-Degrading Bacterium, Syntrophobacter wolinii sp. nov. gen. nov. from Methanogenic Ecosystems. Applied and Environmental Microbiology, v. 40, n. 3, 1980, p. 626-632, 1980.

BOONE, D. R.; CASTENHOLZ, R. W. Bergey's Manual of Systematic Bacteriology. 2. ed. New York: Springer, v. 1, 2001 (The Archaea and the deeply branching and phototrophic Bacteria)

BORSATO, D.; GALÃO, O. F.; MOREIRA, I. Detergentes naturais e sintéticos. Londrina: UEL, 1999. $131 \mathrm{p}$.

BRAGA, J. K.; VARESCHE, M. B. A. Commercial laundry water characterization for anaerobic treatment in fluidized bed reactor. In: X Oficina e Seminário Latino Americano de Digestão Anaeróbia (DAAL). Ouro Preto, MG, 2011.

BRANDT, K. K.; HESSELSOE, M.; ROSLEV, P.; HENRIKSEN, K.; SORENSEN, J. Toxic effects of linear alkylbenzene sulfonate on metabolic activity, growth rate, and microcolony formation of Nitrosomonas and Nitrosospira strains. Applied and Environmental Microbiology, v. 67, n. 6, Jun, p. 2489-2498, 2001.

BRENNER, D. J.; KRIEG, N. R.; STALEY, J. T. Bergey's Manual of Systematic Bacteriology. 2. ed. New York: Springer, v. 2, 2005 (The Proteobacteria)

BROWNAWELL, B. J.; CHEN, H.; ZHANG, W.; WESTALL, J. C. Sorption of non-ionic surfactants on sediment materials. Environment Science Technology, v. 31, p. 1735-1741, 1997.

BUSSE, H. J.; KÄMPFER, P.; MOORE, E. R. B.; NUUTINEN, J.; TSITKO, I. V.; DENNER, E. B. M.; VAUTERIN, L.; VALENS, M.; ROSSELLÓ-MORA, R.; SALKINOJASALONEN, M. S. Thermomonas haemolytica gen. nov., sp. nov., a gamma-proteobacterium from kaolin slurry. International Journal of Systematic and Evolutionary Microbiology, v. 52, n. 2, March 1, 2002, p. 473-83, 2002. 
CADILLO-QUIROZ, H.; YAVITT, J. B.; ZINDER, S. H. Methanosphaerula palustris gen. nov., sp. nov., a hydrogenotrophic methanogen isolated from a minerotrophic fen peatland. International Journal of Systematic and Evolutionary Microbiology, v. 59, n. 5, May 1, 2009, p. 928-935, 2009.

CAPORASO, G.; KUCZYNSKI, J.; STOMBAUGH, J.; BITTINGER, K.; BUSHMAN, F.; COSTELLO, E.; FIERER, N.; PENA, A.; GOODRICH, J.; GORDON, J.; HUTTLEY, G.; KELLEY, S.; KNIGHTS, D.; KOENIG, J.; LEY, R.; LOZUPONE, C.; MCDONALD, D.; MUEGGE, B.; PIRRUNG, M.; REEDER, J.; SEVINSKY, J.; TURNBAUGH, P.; WALTERS, W.; WIDMANN, J.; YATSUNENKO, T.; ZANEVELD, J.; KNIGHT, R. QIIME allows analysis of high-throughput community sequencing data. Nature Methods, v. 7, n. 5, p. 335-336, 2010a.

CAPORASO, J. G.; BITTINGER, K.; BUSHMAN, F. D.; DESANTIS, T. Z.; ANDERSEN, G. L.; KNIGHT, R. PyNAST: a flexible tool for aligning sequences to a template alignment. Bioinformatics, v. 26, n. 2, January 15, 2010, p. 266-267, 2010 b.

CHAKRABORTY, R.; COATES, J. D. Hydroxylation and carboxylation-two crucial steps of anaerobic benzene degradation by Dechloromonas strain RCB. Applied and Environmental Microbiology, v. 71, n. 9, Sep, p. 5427-5432, 2005.

CHAKRABORTY, R.; O'CONNOR, S. M.; CHAN, E.; COATES, J. D. Anaerobic degradation of benzene, toluene, ethylbenzene, and xylene compounds by Dechloromonas strain RCB. Applied and Environmental Microbiology, v. 71, n. 12, Dec, p. 8649-8655, 2005.

CHEN, S.; SONG, L.; DONG, X. Sporacetigenium mesophilum gen. nov., sp. nov., isolated from an anaerobic digester treating municipal solid waste and sewage. International Journal of Systematic and Evolutionary Microbiology, v. 56, n. 4, April 1, 2006, p. 721-725, 2006.

CHIEN, C. C. Arylsulfonates as sole source of sulfur for Clostridium pasteurianum DSM 12136. Journal of Basic Microbiology, v. 45, n. 4, p. 274-278, 2005.

CIABATTIA, I.; CESARO, F.; FARALLI, L.; FATARELLA, E.; TOGNOTTI, F. Demonstration of a treatment system for purification and reuse of laundry wastewater. Desalination, v. 245, n. 1-3, Sep, p. 451-459, 2009.

CLAESSON, M. J.; O'SULlIVAN, O.; WANG, Q.; NIKKILÄ, J.; MARCHESI, J. R.; SMIDT, H.; DE VOS, W. M.; ROSS, R. P.; O'TOOLE, P. W. Comparative Analysis of Pyrosequencing and a Phylogenetic Microarray for Exploring Microbial Community Structures in the Human Distal Intestine. Plos One, v. 4, n. 8, p. e6669, 2009.

COOK, A. M.; LAUE, H.; JUNKER, F. Microbial desulfonation. FEMS Microbiology Reviews, v. 22, n. 5, Dec, p. 399-419, 1998.

COSTERTON, J. W.; LEWANDOWSKI, Z.; CALDWELL, D. E.; KORBER, D. R.; LAPPIN-SCOTT, H. M. Microbial Biofilms. Annual Review of Microbiology, v. 49, n. 1, p. 711-745, 1995.

CSERHATI, T.; FORGACS, E.; OROS, G. Biological activity and environmental impact of anionic surfactants. Environment International, v. 28, n. 5, Nov, p. 337-348, 2002. 
DAIMS, H.; LUCKER, S.; WAGNER, M. daime, a novel image analysis program for microbial ecology and biofilm research. Environmental Microbiology, v. 8, n. 2, Feb, p. 200213, 2006.

DANGMANN, E.; STOLZ, A.; KUHM, A. E.; HAMMER, A.; FEIGEL, B.; NOISOMMITRIZZI, N.; RIZZI, M.; REUSS, M.; KNACKMUSS, H. J. Degradation of 4aminobenzenesulfonate by a two-species bacterial coculture. Biodegradation, v. 7, n. 3, p. 223-229, 1989.

DAVEY, M. E.; O'TOOLE, G. A. Microbial Biofilms: from Ecology to Molecular Genetics. Microbiology and Molecular Biology Reviews, v. 64, n. 4, December 1, 2000, p. 847-867, 2000.

DELFORNO, T. P.; OKADA, D. Y.; POLIZEL, J.; SAKAMOTO, I. K.; VARESCHE, M. B. A. Microbial characterization and removal of anionic surfactant in an expanded granular sludge bed reactor. Bioresource Technology, v. 107, n. 0, p. 103-109, 2012.

DEMHARTER, W.; HENSEL, R.; SMIDA, J.; STACKEBRANDT, E. Sphaerobacter thermophilus gen. nov., sp. nov. A Deeply Rooting Member of the Actinomycetes Subdivision Isolated from Thermophilically Treated Sewage Sludge. Systematic and Applied Microbiology, v. 11, n. 3, p. 261-266, 1989.

DENGER, K.; COOK, A. M. Note: Linear alkylbenzenesulphonate (LAS) bioavailable to anaerobic bacteria as a source of sulphur. Journal of Applied Microbiology, v. 86, n. 1, Jan, p. 165-168, 1999.

DIAZ, C.; BAENA, S.; FARDEAU, M. L.; PATEL, B. K. C. Aminiphilus circumscriptus gen. nov., sp nov., an anaerobic amino-acid-degrading bacterium from an upflow anaerobic sludge reactor. International Journal of Systematic and Evolutionary Microbiology, v. 57, Aug, p. 1914-1918, 2007.

DIPIPPO, J. L.; NESB $\varnothing$, C. L.; DAHLE, H.; DOOLITTLE, W. F.; BIRKLAND, N. K.; NOLL, K. M. Kosmotoga olearia gen. nov., sp. nov., a thermophilic, anaerobic heterotroph isolated from an oil production fluid. International Journal of Systematic and Evolutionary Microbiology, v. 59, n. 12, December 1, 2009, p. 2991-3000, 2009.

DOMINGUES, M. R. Avaliação da metanogênese e sulfetogênese em reatores anaeróbios em batelada e leito fixo, sob condições termofílicas. Dissertação (Mestrado). Escola de Engenharia de São Carlos, Universidade de São Paulo. São Carlos, 2001.

DONG, W.; EICHHORN, P.; RADAJEWSKI, S.; SCHLEHECK, D.; DENGER, K.; KNEPPER, T. P.; MURRELL, J. C.; COOK, A. M. Parvibaculum lavamentivorans converts linear alkylbenzenesulphonate surfactant to sulphophenylcarboxylates, alpha,beta-unsaturated sulphophenylcarboxylates and sulphophenyldicarboxylates, which are degraded in communities. Journal of Applied Microbiology, v. 96, n. 3, p. 630-640, 2004.

DUARTE, I. C. S. Caracterização microbiológica da remoção e degradação de alquilbenzeno linear sulfonado (LAS) em reatores anaeróbios com biofilme e células 
planctônicas. Tese (Doutorado). Escola de Engenharia de São Carlos, Universidade de São Paulo. São Carlos, 2006.

DUARTE, I. C. S.; OLIVEIRA, L. L.; BUZZINI, A. P.; ADORNO, M. A. T.; VARESCHE, M. B. A. Development of a method by HPLC to determine LAS and its application in anaerobic reactors. Journal of the Brazilian Chemical Society, v. 17, n. 7, Nov-Dec, p. 13601367, 2006.

DUARTE, I. C. S.; OLIVEIRA, L. L.; MAYOR, M. S.; OKADA, D. Y.; VARESCHE, M. B. A. Degradation of detergent (linear alkylbenzene sulfonate) in an anaerobic stirred sequencing-batch reactor containing granular biomass. International Biodeterioration \& Biodegradation, v. 64, n. 2, Mar, p. 129-134, 2010a.

DUARTE, I. C. S.; OLIVEIRA, L. L.; SAAVEDRA, N. K.; FANTINATTI-GARBOGGINI, F.; MENEZES, C. B. A.; OLIVEIRA, V. M.; VARESCHE, M. B. A. Treatment of linear alkylbenzene sulfonate in a horizontal anaerobic immobilized biomass reactor. Bioresource Technology, v. 101, n. 2, Jan, p. 606-612, 2010 b.

DUARTE, I. C. S.; OLIVEIRA, L. L.; SAAVEDRA, N. K. D.; FANTINATTIGARBOGGINI, F.; OLIVEIRA, V. M.; VARESCHE, M. B. A. Evaluation of the microbial diversity in a horizontal-flow anaerobic immobilized biomass reactor treating linear alkylbenzene sulfonate. Biodegradation, v. 19, n. 3, p. 375-385, 2008.

EDGAR, R. C. Search and clustering orders of magnitude faster than BLAST. Bioinformatics, August 12, 2010, 2010.

EPA. U. S. Environmental Protection Agency. The Determination of Inorganic Anions in Water by Ion Chromatography - Method 300.0. Cincinnati/Ohio, 1993.

FAHRBACH, M.; KUEVER, J.; MEINKE, R.; KAEMPFER, P.; HOLLENDER, J. Denitratisoma oestradiolicum gen. nov., sp nov., a 17 beta-oestradiol-degrading, denitrifying betaproteobacterium. International Journal of Systematic and Evolutionary Microbiology, v. 56, Jul, p. 1547-1552, 2006.

FALKOW, S.; ROSENBERG, E.; SCHLEIFER, K. H.; STACKEBRANDT, E. The Prokaryotes. 3. ed. New York: Springer, v. 3, 2006 (Archaea. Bacteria: Firmicutes, Actinomycetes)

FERNANDES, C.; RAINEY, F. A.; NOBRE, M. F.; PINHAL, I.; FOLHAS, F.; COSTA, M. S. Herminiimonas fonticola gen. nov., sp nov., a Betaproteobacterium isolated from a source of bottled mineral water. Systematic and Applied Microbiology, v. 28, n. 7, Sep, p. 596-603, 2005 .

FU, M.; ALEXANDER, M. Use of surfactants and slurrying to enhance the biodegradation in soil of compounds initially dissolved in nonaqueous-phase liquids. Applied Microbiology and Biotechnology, v. 43, n. 3, p. 551-558, 1995.

FYTIANOS, K.; VOUDRIAS, E.; PAPAMICHALI, A. Behavior and fate of linear alkylbenzene sulfonate in different soils. Chemosphere, v. 36, n. 13, p. 2741-2746, 1998. 
GANESAN, A.; CHAUSSONNERIE, S.; TARRADE, A.; DAUGA, C.; BOUCHEZ, T.; PELLETIER, E.; LE PASLIER, D.; SGHIR, A. Cloacibacillus evryensis gen. nov., sp nov., a novel asaccharolytic, mesophilic, amino-acid-degrading bacterium within the phylum 'Synergistetes', isolated from an anaerobic sludge digester. International Journal of Systematic and Evolutionary Microbiology, v. 58, Sep, p. 2003-2012, 2008.

GARCIA-MORALES, J. L.; NEBOT, E.; ROMERO, L. I.; SALES, D. Comparison between acidogenic and methanogenic inhibition caused by linear alkylbenzene-sulfonate (LAS). Chemical and Biochemical Engineering Quarterly, v. 15, n. 1, p. 13-19, 2001.

GARCIA, M. T.; CAMPOS, E.; DALMAU, M.; ILLAN, P.; SANCHEZ-LEAL, J. Inhibition of biogas production by alkyl benzene sulfonates (LAS) in a screening test for anaerobic biodegradability. Biodegradation, v. 17, n. 1, Feb, p. 39-46, 2006 a.

GARCIA, M. T.; CAMPOS, E.; DALMAU, M.; RIBOSA, I.; SANCHEZ-LEAL, J. Structure-activity relationships for association of linear alkylbenzene sulfonates with activated sludge. Chemosphere, v. 49, n. 3, p. 279-286, 2002.

GARCIA, M. T.; CAMPOS, E.; SANCHEZ-LEAL, J.; RIBOSA, I. Effect of linear alkylbenzene sulphonates (LAS) on the anaerobic digestion of sewage sludge. Water Research, v. 40, n. 15, p. 2958-2964, 2006b.

GARCIA, R. O.; REICHENBACH, H.; RING, M. W.; MÜLLER, R. Phaselicystis flava gen. nov., sp. nov., an arachidonic acid-containing soil myxobacterium, and the description of Phaselicystidaceae fam. nov. International Journal of Systematic and Evolutionary Microbiology, v. 59, n. 6, June 1, 2009, p. 1524-1530, 2009.

GARRITY, G. M.; BROWN, A.; VICKERS, R. M. Tatlockia and Fluoribacter - Two New Genera of Organisms Resembling Legionella-Pneumophila. International Journal of Systematic Bacteriology, v. 30, n. 4, 1980, p. 609-614, 1980.

GESCHER, J.; ZAAR, A.; MOHAMED, M.; SCHAGGER, H.; FUCHS, G. Genes coding for a new pathway of aerobic benzoate metabolism in Azoarcus evansii. Journal of Bacteriology, v. 184, n. 22, Nov, p. 6301-6315, 2002.

GRIFFITHS, R. I.; WHITELEY, A. S.; O'DONNELL, A. G.; BAILEY, M. J. Rapid method for coextraction of DNA and RNA from natural environments for analysis of ribosomal DNA- and rRNA-based microbial community composition. Applied and Environmental Microbiology, v. 66, n. 12, Dec, p. 5488-5491, 2000.

HAGGENSEN, F.; MOGENSEN, A. S.; ANGELIDAKI, I.; AHRING, B. K. Anaerobic treatment of sludge: focusing on reduction of LAS concentration in sludge. Water Science and Technology, v. 46, n. 10, p. 159-165, 2002.

HAHN, D.; AMANN, R. I.; LUDWIG, W.; AKKERMANS, A. D. L.; SCHLEIFER, K. H. Detection of microorganisms in soil after in situ hybridization with ribosomal-RNA-targeted, fluorescently labeled oligonucleotides. Journal of General Microbiology, v. 138, May, p. 879887, 1992. 
HAND, V. C.; WILLIAMS, G. K. Structure-activity-relationships for sorption of linear alkylbenzenesulfonates. Environmental Science \& Technology, v. 21, n. 4, p. 370-373, 1987.

HARWOOD, C. S.; GIBSON, J. Anaerobic and aerobic metabolism of diverse aromatic compounds by the photosynthetic bacterium Rhodopseudomonas palustris. Applied and Environmental Microbiology, v. 54, n. 3, March 1, 1988, p. 712-717, 1988.

HIRASAWA, J. S.; SARTI, A.; DEL AGUILA, N. K. S.; VARESCHE, M. B. A. Application of molecular techniques to evaluate the methanogenic archaea and anaerobic bacteria in the presence of oxygen with different COD:Sulfate ratios in a UASB reactor. Anaerobe, v. 14, n. 4, p. 209-218, 2008.

HONG, S. B.; RAUSHEL, F. M. Metal-substrate interactions facilitate the catalytic activity of the bacterial phosphotriesterase. Biochemistry, v. 35, n. 33, 1996/01/01, p. 10904-10912, 1996.

HOSSEINI, S. N.; BORGHEI, S. M. Removal of alkylbenzene sulfonate (ABS) from detergent industries wastewater by activated sludge. In: 9th International Conference on Environmental Science and Technology. Rhodes Isl, GREECE: Univ Aegean, 2005.

HOUF, K.; ON, S. L. W.; COENYE, T.; MAST, J.; VAN HOOF, J.; VANDAMME, P. Arcobacter cibarius sp nov., isolated from broiler carcasses. International Journal of Systematic and Evolutionary Microbiology, v. 55, Mar, p. 713-717, 2005.

HSU, T. D.; LUX, M. F.; DRAKE, H. L. Expression of an aromatic-dependent decarboxylase which provides growth-essential $\mathrm{CO}_{2}$ equivalents for the acetogenic (wood) pathway of Clostridium-thermoaceticum. Journal of Bacteriology, v. 172, n. 10, Oct, p. 5901-5907, 1990.

HUGENHOLTZ, P.; STACKEBRANDT, E. Reclassification of Sphaerobacter thermophilus from the subclass Sphaerobacteridae in the phylum Actinobacteria to the class Thermomicrobia (emended description) in the phylum Chloroflexi (emended description). International Journal of Systematic and Evolutionary Microbiology, v. 54, n. 6, November 1, 2004, p. 2049-2051, 2004.

IMACHI, H.; SAKAI, S.; SEKIGUCHI, Y.; HANADA, S.; KAMAGATA, Y.; OHASHI, A.; HARADA, H. Methanolinea tarda gen. nov., sp. nov., a methane-producing archaeon isolated from a methanogenic digester sludge. International Journal of Systematic and Evolutionary Microbiology, v. 58, n. 1, January 1, 2008, p. 294-301, 2008.

JENSEN, J. Fate and effects of linear alkylbenzene sulphonates (LAS) in the terrestrial environment. Science of the Total Environment, v. 226, n. 2-3, p. 93-111, 1999.

JIANG, S.; CHEN, Y. G.; ZHOU, Q.; GU, G. W. Biological short-chain fatty acids (SCFAs) production from waste-activated sludge affected by surfactant. Water Research, v. 41, n. 14, Jul, p. 3112-3120, 2007.

JIMENEZ, L.; BREEN, A.; THOMAS, N.; FEDERLE, T. W.; SAYLER, G. S. Mineralization of linear alkylbenzene sulfonate by a 4-member aerobic bacterial consortium. Applied and Environmental Microbiology, v. 57, n. 5, p. 1566-1569, 1991. 
KÄMPFER, P.; YOUNG, C. C.; ARUN, A. B.; SHEN, F. T.; JÄCKEL, U.; ROSSELLÓMORA, R.; LAI, W. A.; REKHA, P. D. Pseudolabrys taiwanensis gen. nov., sp. nov., an alphaproteobacterium isolated from soil. International Journal of Systematic and Evolutionary Microbiology, v. 56, n. 10, October 1, 2006, p. 2469-2472, 2006.

KANG, S. J.; CHOI, N. S.; CHOI, J. H.; LEE, J. S.; YOON, J. H.; SONG, J. J. Brevundimonas naejangsanensis sp. nov., a proteolytic bacterium isolated from soil, and reclassification of Mycoplana bullata into the genus Brevundimonas as Brevundimonas bullata comb. nov. International Journal of Systematic and Evolutionary Microbiology, v. 59, n. 12, December 1, 2009, p. 3155-3160, 2009.

KEENER, W. K.; ARP, D. J. Transformations of Aromatic Compounds by Nitrosomonas europaea. Applied and Environmental Microbiology, v. 60, n. 6, June 1, 1994, p. 1914-1920, 1994.

KELLY, D. P.; MCDONALD, I. R.; WOOD, A. P. Proposal for the reclassification of Thiobacillus novellus as Starkeya novella gen. nov., comb. nov., in the alpha-subclass of the Proteobacteria. International Journal of Systematic and Evolutionary Microbiology, v. 50, n. 5, September 1, 2000, p. 1797-802, 2000.

KERTESZ, M. A.; KOLBENER, P.; STOCKINGER, H.; BEIL, S.; COOK, A. M. Desulfonation of linear alkylbenzenesulfonate surfactants and related-compounds by bacteria. Applied and Environmental Microbiology, v. 60, n. 7, Jul, p. 2296-2303, 1994.

KERTESZ, M. A.; SCHMIDT-LARBIG, K.; WUEST, T. A novel reduced flavin mononucleotide-dependent methanesulfonate sulfonatase encoded by the sulfur-regulated $m s u$ operon of Pseudomonas aeruginosa. Journal of Bacteriology, v. 181, n. 5, Mar, p. 1464-1473, 1999.

KHLEIFAT, K. M. Biodegradation of linear alkylbenzene sulfonate by a two-member facultative anaerobic bacterial consortium. Enzyme and Microbial Technology, v. 39, n. 5, p. 1030-1035, 2006a.

KHLEIFAT, K. M. Biodegradation of linear alkylbenzene sulfonate by a two-member facultative anaerobic bacterial consortium. Enzime and Microbial Technology, v. 39, n. 5, p. 1030-1035, 2006b.

KIMERLE, R. A.; SWISHER, R. D. Reduction of aquatic toxicity of linear alkylbenzene sulfonate (LAS) by biodegradation. Water Research, v. 11, n. 1, p. 31-37, 1977.

KNAEBEL, D. B.; FEDERLE, T. W.; MCAVOY, D. C.; VESTAL, J. R. Microbial mineralization of organic compounds in an acidic agricultural soil: Effects of preadsorption to various soil constituents. Environmental Toxicology and Chemistry, v. 15, n. 11, p. 1865$1875,1996$.

KODAMA, Y.; WATANABE, K. Sulfuricurvum kujiense gen. nov., sp. nov., a facultatively anaerobic, chemolithoautotrophic, sulfur-oxidizing bacterium isolated from an underground crude-oil storage cavity. International Journal of Systematic and Evolutionary Microbiology, v. 54, n. 6, November 1, 2004, p. 2297-2300, 2004. 
KRIEG, N. R.; STALEY, J. T.; BROWN, D. R.; HEDLUND, B. P.; PASTER, B. J.; WARD, N. L.; LUDWIG, W.; WHITMAN, W. B. Bergey's Manual of Systematic Bacteriology. 2. ed. New York: Springer, v. 4, 2010 (The Bacterioidetes, Spirochaetes, Tenericutes (Mollicutes), Acidobacteria, Fibrobacteres, Fusobacteria, Dictyoglomi, Gemmatimonadetes, Lentisphaerae, Verrucomicrobia, Chlamydiae, and Plantomycetes)

KUDO, Y.; NAKAJIMA, T.; MIYAKI, T.; OYAIZU, H. Methanogen flora of paddy soils in Japan. FEMS Microbiology Ecology, v. 22, n. 1, Jan, p. 39-48, 1997.

KUMAR, A. G.; KIRUBAGARAN, R.; NAGESH, N.; PARRADO RUBIO, J.; SEKARAN, G. Influence of fermentation metabolites on redox potential in anaerobic digestion of proteinaceous solid wastes by Synergistes sp. Engineering in Life Sciences, v. 10, n. 4, p. 368$373,2010$.

LAI, Q.; YUAN, J.; WU, C.; SHAO, Z. Oceanibaculum indicum gen. nov., sp. nov., isolated from deep seawater of the Indian Ocean. International Journal of Systematic and Evolutionary Microbiology, v. 59, n. 7, July 1, 2009, p. 1733-1737, 2009.

LANE, D. J. 16S/23S rRNA sequencing. In: STACKEBRANDT, E.; GOODFELOW, M. (Ed.). Nucleic acid techniques in bacterial systematic. Chichestre, UK: Wiley, 1991. p.115175

LARA-MARTIN, P. A.; CORADA-FERNANDEZ, C.; GOMEZ-PARRA, A.; GONZALEZMAZO, E. Seasonal changes in the concentration of anionic surfactants in estuarine sediments from the River Guadalete (Cadiz, Spain). Scientia Marina, v. 74, Dec, p. 125-131, 2010a.

LARA-MARTIN, P. A.; GOMEZ-PARRA, A.; KOCHLING, T.; SANZ, J. L.; AMILS, R.; GONZALEZ-MAZO, E. Anaerobic degradation of linear alkylbenzene sulfonates in coastal marine sediments. Environmental Science \& Technology, v. 41, n. 10, May 15, p. 3573-3579, 2007.

LARA-MARTIN, P. A.; GOMEZ-PARRA, A.; SANZ, J. L.; GONZALEZ-MAZO, E. Anaerobic Degradation Pathway of Linear Alkylbenzene Sulfonates (LAS) in SulfateReducing Marine Sediments. Environmental Science \& Technology, v. 44, n. 5, Mar, p. 16701676, $2010 \mathrm{~b}$.

LARA-MARTIN, P. A.; PETROVIC, M.; GOMEZ-PARRA, A.; BARCELO, D.; GONZALEZ-MAZO, E. Presence of surfactants and their degradation intermediates in sediment cores and grabs from the Cadiz Bay area. Environmental Pollution, v. 144, n. 2, Nov, p. 483-491, 2006.

LARSON, R. J.; ROTHGEB, T. M.; SHIMP, R. J.; WARD, T. E.; VENTULLO, R. M. Kinetics and practical significance of biodegradation of linear alkylbenzene sulfonate in the environment. Journal of the American Oil Chemists Society, v. 70, n. 7, Jul, p. 645-657, 1993.

LAUE, H.; DENGER, K.; COOK, A. M. Taurine reduction in anaerobic respiration of Bilophila wadsworthia RZATAU. Applied and Environmental Microbiology, v. 63, n. 5, May 1, 1997, p. 2016-21, 1997. 
LAZARO, C. Z.; HIRASAWA, J. S.; VARESCHE, M. B. A.; ADORNO, M. A. T. Development of an HPLC method for the analysis of eleven short chain organic acids in bioproduction of hydrogen. In: XII Congresso Latino-Americano de Cromatografia $e$ Técnicas Relacionadas (COLACRO). Florianópolis, SC, 2008.

LIE, T. J.; GODCHAUX, W.; LEADBETTER, E. R. Sulfonates as terminal electron acceptors for growth of sulfite-reducing bacteria (Desulfitobacterium spp.) and sulfatereducing bacteria: Effects of inhibitors of sulfidogenesis. Applied and Environmental Microbiology, v. 65, n. 10, p. 4611-4617, 1999.

LIESACK, W.; BAK, F.; KREFT, J. U.; STACKEBRANDT, E. Holophaga foetida gen. nov., sp. nov., a new, homoacetogenic bacterium degrading methoxylated aromatic compounds. Archives of Microbiology, v. 162, n. 1, p. 85-90, 1994.

LIM, J. H.; BAEK, S. H.; LEE, S. T. Ferruginibacter alkalilentus gen. nov., sp. nov. and Ferruginibacter lapsinanis sp. nov., novel members of the family 'Chitinophagaceae' in the phylum Bacteroidetes, isolated from freshwater sediment. International Journal of Systematic and Evolutionary Microbiology, v. 59, n. 10, October 1, 2009, p. 2394-2399, 2009.

LOBNER, T.; TORANG, L.; BATSTONE, D. J.; SCHMIDT, J. E.; ANGELIDAKI, I. Effects of process stability on anaerobic biodegradation of LAS in UASB reactors. Biotechnology and Bioengineering, v. 89, n. 7, p. 759-765, 2005.

LODE, E. T.; COON, M. J. Enzymatic w-oxidation. V. Forms of Pseudomonas oleovorans rubredoxin containing one or two iron atoms: structure and function in w-hydroxylation. Journal of Biological Chemistry, v. 246, n. 3, p. 791-\&, 1971.

LU, S.; RYU, S. H.; CHUNG, B. S.; CHUNG, Y. R.; PARK, W.; JEON, C. O. Simplicispira limi sp. nov., isolated from activated sludge. International Journal of Systematic and Evolutionary Microbiology, v. 57, n. 1, January 1, 2007, p. 31-34, 2007.

LUEDEMAN, G. M. Geodermatophilus a New Genus of Dermatophilaceae (Actinomycetales). Journal of Bacteriology, v. 96, n. 5, 1968, p. 1848-\&, 1968.

MADSEN, T.; RASMUSSEN, H. B. A method for screening the potential toxicity of organic chemicals to methanogenic gas production. Water Science and Technology, v. 33, n. 6, p. 213-220, 1996.

MANZ, W.; AMANN, R.; LUDWIG, W.; WAGNER, M.; SCHLEIFER, K. H. Phylogenetic oligodeoxynucleotide probes for the major subclasses of proteobacteria - problems and solutions. Systematic and Applied Microbiology, v. 15, n. 4, p. 593-600, 1992.

MARGUliES, M.; EGHOLM, M.; ALTMAN, W. E.; ATTIYA, S.; BADER, J. S.; BEMBEN, L. A.; BERKA, J.; BRAVERMAN, M. S.; CHEN, Y. J.; CHEN, Z.; DEWELL, S. B.; DU, L.; FIERRO, J. M.; GOMES, X. V.; GODWIN, B. C.; HE, W.; HELGESEN, S.; HO, C. H.; IRZYK, G. P.; JANDO, S. C.; ALENQUER, M. L. I.; JARVIE, T. P.; JIRAGE, K. B.; KIM, J. B.; KNIGHT, J. R.; LANZA, J. R.; LEAMON, J. H.; LEFKOWITZ, S. M.; LEI, M.; LI, J.; LOHMAN, K. L.; LU, H.; MAKHIJANI, V. B.; MCDADE, K. E.; MCKENNA, M. P.; MYERS, E. W.; NICKERSON, E.; NOBILE, J. R.; PLANT, R.; PUC, B. P.; RONAN, M. T.; ROTH, G. T.; SARKIS, G. J.; SIMONS, J. F.; SIMPSON, J. W.; SRINIVASAN, M.; 
TARTARO, K. R.; TOMASZ, A.; VOGT, K. A.; VOLKMER, G. A.; WANG, S. H.; WANG, Y.; WEINER, M. P.; YU, P.; BEGLEY, R. F.; ROTHBERG, J. M. Genome sequencing in microfabricated high-density picolitre reactors. Nature, v. 437, n. 7057, p. 376-380, 2005.

MARTINEZ-PASCUAL, E.; JIMENEZ, N.; VIDAL-GAVILAN, G.; VINAS, M.; SOLANAS, A. M. Chemical and microbial community analysis during aerobic biostimulation assays of non-sulfonated alkyl-benzene-contaminated groundwater. Applied Microbiology and Biotechnology, v. 88, n. 4, Oct, p. 985-995, 2010.

MARUYAMA, T.; PARK, H. D.; OZAWA, K.; TANAKA, Y.; SUMINO, T.; HAMANA, K.; HIRAISHI, A.; KATO, K. Sphingosinicella microcystinivorans gen. nov., sp. nov., a microcystin-degrading bacterium. International Journal of Systematic and Evolutionary Microbiology, v. 56, n. 1, January 1, 2006, p. 85-89, 2006.

MCINERNEY, M. J.; BRYANT, M. P.; HESPELL, R. B.; COSTERTON, J. W. Syntrophomonas wolfei gen. nov. sp. nov., an Anaerobic, Syntrophic, Fatty Acid-Oxidizing Bacterium. Applied and Environmental Microbiology, v. 41, n. 4, April 1, 1981, p. 10291039, 1981.

MECHICHI, T.; LABAT, M.; PATEL, B. K. C.; WOO, T. H. S.; THOMAS, P.; GARCIA, J. L. Clostridium methoxybenzovorans sp nov., a new aromatic o-demethylating homoacetogen from an olive mill wastewater treatment digester. International Journal of Systematic Bacteriology, v. 49, Jul, p. 1201-1209, 1999.

MECHICHI, T.; PATEL, B. K. C.; SAYADI, S. Anaerobic degradation of methoxylated aromatic compounds by Clostridium methoxybenzovorans and a nitrate-reducing bacterium Thauera sp strain Cin3,4. International Biodeterioration \& Biodegradation, v. 56, n. 4, Dec, p. 224-230, 2005.

MOGENSEN, A. S.; AHRING, B. K. Formation of metabolites during biodegradation of linear alkylbenzene sulfonate in an upflow anaerobic sludge bed reactor under thermophilic conditions. Biotechnology and Bioengineering, v. 77, n. 5, p. 483-488, 2002.

MOGENSEN, A. S.; HAAGENSEN, F.; AHRING, B. K. Anaerobic degradation of linear alkylbenzene sulfonate. Environmental Toxicology and Chemistry, v. 22, n. 4, p. 706-711, 2003.

MONCIARDINI, P.; CAVALETTI, L.; SCHUMANN, P.; ROHDE, M.; DONADIO, S. Conexibacter woesei gen. nov., sp nov., a novel representative of a deep evolutionary line of descent within the class Actinobacteria. International Journal of Systematic and Evolutionary Microbiology, v. 53, Mar, p. 569-576, 2003.

MORAES, E. M.; ADORNO, M. A. T.; ZAIAT, M.; FORESTI, E. Determinação de ácidos voláteis por cromatografia gasosa em efluentes de reatores anaeróbios tratando resíduos líquidos e sólidos. In: VI Oficina e seminário latino-americano de digestão anaeróbia. Recife, PE: UFPE, 2000.

MORITA, D. M.; SANTANA, J. M. Comparação entre o método do azul de metileno e cromatografia líquida de alta pressão (HPLC) para determinação das concentrações de surfactantes aniônicos em esgotos sanitários. In: $23^{\circ}$ Congresso Brasileiro de Engenharia 
Sanitária e Ambiental. Saneamento ambiental Brasileiro: Utopia ou realidade? Campo Grande: ABES, 2005.

MOSCHE, M.; MEYER, U. Toxicity of linear alkylbenzene sulfonate in anaerobic digestion: influence of exposure time. Water Research, v. 36, n. 13, p. 3253-3260, 2002.

MUNGRAY, A. K.; KUMAR, P. Fate of Anionic Surfactants in a 38 ML/Day UASB-Based Municipal Wastewater Treatment Plant: Case Study. Journal of Environmental EngineeringAsce, v. 134, n. 12, Dec, p. 1014-1022, 2008.

MUNGRAY, A. K.; KUMAR, P. Fate of linear alkylbenzene sulfonates in the environment: A review. International Biodeterioration \& Biodegradation, v. 63, n. 8, Dec, p. 981-987, 2009a.

MUNGRAY, A. K.; KUMAR, P. Mass balance of anionic surfactants through up-flow anaerobic sludge blanket based sewage treatment plants. Process Safety and Environmental Protection, v. 87, n. 4, Jul, p. 254-260, 2009 b.

MYHR, S.; TORSVIK, T. Denitrovibrio acetiphilus, a novel genus and species of dissimilatory nitrate-reducing bacterium isolated from an oil reservoir model column. International Journal of Systematic and Evolutionary Microbiology, v. 50, Jul, p. 1611-1619, 2000.

NAKATSU, C. H.; HRISTOVA, K.; HANADA, S.; MENG, X. Y.; HANSON, J. R.; SCOW, K. M.; KAMAGATA, Y. Methylibium petroleiphilum gen. nov., sp. nov., a novel methyl tertbutyl ether-degrading methylotroph of the Betaproteobacteria. International Journal of Systematic and Evolutionary Microbiology, v. 56, n. 5, May 1, 2006, p. 983-989, 2006.

NAVAS, J. M.; GONZALEZ-MAZO, E.; WENZEL, A.; GOMEZ-PARRA, A.; SEGNER, H. Linear alkylbenzene sulfonates and intermediate products from their degradation are not estrogenic. Marine Pollution Bulletin, v. 38, n. 10, p. 880-884, 1999.

NIELSEN, A. T.; LIU, W. T.; FILIPE, C.; GRADY, L.; MOLIN, S.; STAHL, D. A. Identification of a novel group of bacteria in sludge from a deteriorated biological phosphorus removal reactor. Applied and Environmental Microbiology, v. 65, n. 3, Mar, p. 1251-1258, 1999.

OLIVEIRA, L. L.; COSTA, R. B.; OKADA, D. Y.; VICH, D. V.; DUARTE, I. C. S.; SILVA, E. L.; VARESCHE, M. B. A. Anaerobic degradation of linear alkylbenzene sulfonate (LAS) in fluidized bed reactor by microbial consortia in different support materials. Bioresource Technology, v. 101, n. 14, Jul, p. 5112-5122, 2010.

OLIVEIRA, L. L.; DUARTE, I. C. S.; SAKAMOTO, I. K.; VARESCHE, M. B. A. Influence of support material on the immobilization of biomass for the degradation of linear alkylbenzene sulfonate in anaerobic reactors. Journal of Environmental Management, v. 90, n. 2, Feb, p. 1261-1268, 2009.

OU, Z.; YEDILER, A.; HE, Y.; JIA, L.; KETTRUP, A.; SUN, T. Adsorption of linear alkylbenzene sulfonate (LAS) on soils. Chemosphere, v. 32, n. 5, p. 827-839, 1996. 
OUATTARA, A. S.; ASSIH, E. A.; THIERRY, S.; CAYOL, J. L.; LABAT, M.; MONROY, O.; MACARIE, H. Bosea minatitlanensis sp. nov., a strictly aerobic bacterium isolated from an anaerobic digester. International Journal of Systematic and Evolutionary Microbiology, v. 53, n. 5, September 1, 2003, p. 1247-1251, 2003.

PAKOU, C.; KORNAROS, M.; STAMATELATOU, K.; LYBERATOS, G. On the fate of LAS, NPEOs and DEHP in municipal sewage sludge during composting. Bioresource Technology, v. 100, n. 4, Feb, p. 1634-1642, 2009.

PARSHINA, S. N.; KLEEREBEZEM, R.; SANZ, J. L.; LETTINGA, G.; NOZHEVNIKOVA, A. N.; KOSTRIKINA, N. A.; LYSENKO, A. M.; STAMS, A. J. M. Soehngenia saccharolytica gen. nov., sp. nov. and Clostridium amygdalinum sp. nov., two novel anaerobic, benzaldehyde-converting bacteria. International Journal of Systematic and Evolutionary Microbiology, v. 53, n. 6, November 1, 2003, p. 1791-1799, 2003.

PATI, A.; LABUTTI, K.; PUKALL, R.; NOLAN, M.; GLAVINA DEL RIO, T.; TICE, H.; CHENG, J. F.; LUCAS, S.; CHEN, F.; COPELAND, A.; IVANOVA, N.; MAVROMATIS, K.; MIKHAILOVA, N.; PITLUCK, S.; BRUCE, D.; GOODWIN, L.; LAND, M.; HAUSER, L.; CHANG, Y. J.; JEFFRIES, C. D.; CHEN, A.; PALANIAPPAN, K.; CHAIN, P.; BRETTIN, T.; ROHDE, M.; GÖKER, M.; BRISTOW, J.; EISEN, J. A.; MARKOWITZ, V.; HUGENHOLTZ, P.; KYRPIDES, N. C.; KLENK, H. P.; LAPIDUS, A. Complete genome sequence of Sphaerobacter thermophilus type strain (S 6022 T). v. 2, 2010 (2010)

PERKOWSKI, J.; KOS, L.; LEDAKOWICZ, S. Advanced Oxidation of Textile Wastewaters. Ozone: Science \& Engineering, v. 22, n. 5, 2000/10/01, p. 535-550, 2000.

PINEDA-FLORES, G.; BADILLO, C. M.; CORTAZAR, M. H.; HIPOLITO, C. N.; PEREZ, R. S.; SANCHEZ, I. G. Toxic effects of linear alkylbenzene sulfonate, anthracene and their mixture on growth of a microbial consortium isolated from polluted sediment. Revista Internacional De Contaminacion Ambiental, v. 26, n. 1, Feb, p. 39-46, 2010.

PRAUSER, H. Nocardioides, a New Genus of Order Actinomycetales. International Journal of Systematic Bacteriology, v. 26, n. 1, 1976, p. 58-65, 1976.

PRICE, M. N.; DEHAL, P. S.; ARKIN, A. P. FastTree: Computing Large Minimum Evolution Trees with Profiles instead of a Distance Matrix. Molecular Biology and Evolution, v. 26, n. 7, July 1, 2009, p. 1641-1650, 2009.

QU, J. H.; YUAN, H. L. Sediminibacterium salmoneum gen. nov., sp. nov., a member of the phylum Bacteroidetes isolated from sediment of a eutrophic reservoir. International Journal of Systematic and Evolutionary Microbiology, v. 58, n. 9, September 1, 2008, p. 2191-2194, 2008.

REICHENBECHER, W.; SCHINK, B. Desulfovibrio inopinatus, sp. nov., a new sulfatereducing bacterium that degrades hydroxyhydroquinone (1,2,4-trihydroxybenzene). Archives of Microbiology, v. 168, n. 4, p. 338-344, 1997.

RIPLEY, L. E.; BOYLE, W. C.; CONVERSE, L. C. Improved alkalinetric monitoring for anaerobic digestion of high-strength wastes. Journal WPCF, v. 58, p. 106-111, 1986. 
RITTMANN, B. E.; TULARAK, P.; LEE, K. C.; FEDERLE, T. W.; ITRICH, N. R.; KAISER, S. K.; SHI, J.; MCAVOY, D. C. How adaptation and mass transfer control the biodegradation of linear alkylbenzene sulfonate by activated sludge. Biodegradation, v. 12, n. 1, p. 31-37, 2001.

SAKAMOTO, I. K.; VARESCHE, M. B. A. Quantificação de Bactérias Redutoras de Sulfato pela Técnica dos Tubos Múltiplos. Procedimento Operacional Padrão (POP).São Paulo, 2011. Documento da Rede PROSAB Microbiologia para o Saneamento Básico. Área: Métodos Básicos. Disponível em 〈http://www.prosabmicrobiologia.org.br/rede/protocolos> acesso em 11 Nov. 2011.

SAKAMOTO, M.; BENNO, Y. Reclassification of Bacteroides distasonis, Bacteroides goldsteinii and Bacteroides merdae as Parabacteroides distasonis gen. nov., comb. nov., Parabacteroides goldsteinii comb. nov. and Parabacteroides merdae comb. nov. International Journal of Systematic and Evolutionary Microbiology, v. 56, n. 7, July 1, 2006, p. 1599-1605, 2006.

SALINERO, K.; KELLER, K.; FEIL, W.; FEIL, H.; TRONG, S.; DI BARTOLO, G.; LAPIDUS, A. Metabolic analysis of the soil microbe Dechloromonas aromatica str. RCB: indications of a surprisingly complex life-style and cryptic anaerobic pathways for aromatic degradation. BMC Genomics, v. 10, n. 1, p. 351, 2009.

SANCHEZ-PEINADO, M. D.; GONZALEZ-LOPEZ, J.; MARTINEZ-TOLEDO, M. V.; POZO, C.; RODELAS, B. Influence of linear alkylbenzene sulfonate (LAS) on the structure of Alphaproteobacteria, Actinobacteria, and Acidobacteria communities in a soil microcosm. Environmental Science and Pollution Research, v. 17, n. 3, Mar, p. 779-790, 2010.

SANZ, J. L.; CULUBRET, E.; DE FERRER, J.; MORENO, A.; BERNA, J. L. Anaerobic biodegradation of linear alkylbenzene sulfonate (LAS) in upflow anaerobic sludge blanket (UASB) reactors. Biodegradation, v. 14, n. 1, p. 57-64, 2003.

SCHLEHECK, D.; COOK, A. M. w-Oxygenation of the alkyl sidechain of linear alkylbenzenesulfonate (LAS) surfactant in Parvibaculum lavamentivorans ${ }^{\mathrm{T}}$. Archives of Microbiology, v. 183, n. 6, Sep, p. 369-377, 2005.

SCHLEHECK, D.; KNEPPER, T. P.; FISCHER, K.; COOK, A. M. Mineralization of individual congeners of linear alkylbenzenesulfonate by defined pairs of heterotrophic bacteria. Applied and Environmental Microbiology, v. 70, n. 7, Jul, p. 4053-4063, 2004a.

SCHLEHECK, D.; TINDALL, B. J.; ROSSELLO-MORA, R.; COOK, A. M. Parvibaculum lavamentivorans gen. nov., sp nov., a novel heterotroph that initiates catabolism of linear alkylbenzenesulfonate. International Journal of Systematic and Evolutionary Microbiology, v. 54, Sep, p. 1489-1497, 2004b.

SCHLEHECK, D.; VON NETZER, F.; FLEISCHMANN, T.; RENTSCH, D.; HUHN, T.; COOK, A. M.; KOHLER, H. P. E. The Missing Link in Linear Alkylbenzenesulfonate Surfactant Degradation: 4-Sulfoacetophenone as a Transient Intermediate in the Degradation of 3-(4-Sulfophenyl)Butyrate by Comamonas testosteroni KF-1. Applied and Environmental Microbiology, v. 76, n. 1, Jan, p. 196-202, 2010. 
SCHMIDT, J. E.; AHRING, B. K. Granular sludge formation in upflow anaerobic sledge blanket (UASB) reactors. Biotechnology and Bioengineering, v. 49, n. 3, Feb, p. 229-246, 1996.

SCHÖRBERL, P. Basics principles of LAS biodegradation. Tenside Surfactants Detergents, v. 26, p. 86-94, 1989.

SCHOUTEN, N.; VAN DER HAM, L. G. J.; EUVERINK, G. J. W.; DE HAAN, A. B. Selection and evaluation of adsorbents for the removal of anionic surfactants from laundry rinsing water. Water Research, v. 41, p. 4233-4241, 2007.

SEGERS, P.; VANCANNEYT, M.; POT, B.; TORCK, U.; HOSTE, B.; DEWETTINCK, D.; FALSEN, E.; KERSTERS, K.; VOS, P. D. Classification of Pseudomonas diminuta Leifson and Hugh 1954 and Pseudomonas vesicularis Büsing, Döll, and Freytag 1953 in Brevundimonas gen. nov. as Brevundimonas diminuta comb. nov. and Brevundimonas vesicularis comb. nov., Respectively. International Journal of Systematic Bacteriology, v. 44, n. 3, July 1, 1994, p. 499-510, 1994.

SEKIGUCHI, Y.; YAMADA, T.; HANADA, S.; OHASHI, A.; HARADA, H.; KAMAGATA, Y. Anaerolinea thermophila gen. nov., sp. nov. and Caldilinea aerophila gen. nov., sp. nov., novel filamentous thermophiles that represent a previously uncultured lineage of the domain Bacteria at the subphylum level. International Journal of Systematic and Evolutionary Microbiology, v. 53, n. 6, November 1, 2003, p. 1843-1851, 2003.

SEO, G. T.; LEE, T. S.; MOON, B. H.; LIM, J. H. Ultrafiltration combined with ozone for domestic laundry wastewater reclamation and reuse. In: BALABAN, M.; SCHIPPERS, J. C. (Ed.). Membranes in Drinking and Industrial Water Production Ii. London: Iwa Publishing, v.1, 2001. p.387-392. (Water Science and Technology: Water Supply)

SHELTON, D. R.; TIEDJE, J. M. General-method for determining anaerobic biodegradation potential. Applied and Environmental Microbiology, v. 47, n. 4, p. 850-857, 1984.

SIGOILLOT, J. C.; NGUYEN, M. H. Complete oxidation of linear alkylbenzene sulfonate by bacterial communities selected from coastal seawater. Applied and Environmental Microbiology, v. 58, n. 4, Apr, p. 1308-1312, 1992.

SINGLETON, D. R.; FURLONG, M. A.; PEACOCK, A. D.; WHITE, D. C.; COLEMAN, D. C.; WHITMAN, W. B. Solirubrobacter pauli gen. nov., sp. nov., a mesophilic bacterium within the Rubrobacteridae related to common soil clones. International Journal of Systematic and Evolutionary Microbiology, v. 53, n. 2, March 1, 2003, p. 485-490, 2003.

ŠOSTAR-TURK, S.; PETRINIĆ, I.; SIMONIČ, M. Laundry wastewater treatment using coagulation and membrane filtration. Resources, Conservation and Recycling, v. 44, n. 2, p. 185-196, 2005.

STAHL, D. A.; AMANN, R. I. Development and application of nucleic acid probes. In: STACKEBRANDT, E.; GOODFELOW, M. (Ed.). Nucleic acid techniques in bacterial systematics. Chichester, United Kingdom: John Wiley \& Sons, Ltd., v.8, 1991. p.207-248 
STEIERT, J. G.; PIGNATELlO, J. J.; CRAWFORD, R. L. Degradation of chlorinated phenols by a pentachlorophenol-degrading bacterium. Applied and Environmental Microbiology, v. 53, n. 5, May 1, 1987, p. 907-910, 1987.

STOVER, C. K.; PHAM, X. Q.; ERWIN, A. L.; MIZOGUCHI, S. D.; WARRENER, P.; HICKEY, M. J.; BRINKMAN, F. S. L.; HUFNAGLE, W. O.; KOWALIK, D. J.; LAGROU, M.; GARBER, R. L.; GOLTRY, L.; TOLENTINO, E.; WESTBROCK-WADMAN, S.; YUAN, Y.; BRODY, L. L.; COULTER, S. N.; FOLGER, K. R.; KAS, A.; LARBIG, K.; LIM, R.; SMITH, K.; SPENCER, D.; WONG, G. K. S.; WU, Z.; PAULSEN, I. T.; REIZER, J.; SAIER, M. H.; HANCOCK, R. E. W.; LORY, S.; OLSON, M. V. Complete genome sequence of Pseudomonas aeruginosa PAO1, an opportunistic pathogen. Nature, v. 406, n. 6799, p. 959-964, 2000.

SWISHER, R. D. Surfactant biodegradation. 2. ed. Nova Iorque: CRC Press, 1987. 17-45 p.

TABREZ KHAN, S.; HIRAISHI, A. Diaphorobacter nitroreducens gen. nov., sp. nov., a poly(3-hydroxybutyrate)-degrading denitrifying bacterium isolated from activated sludge. The Journal of General and Applied Microbiology, v. 48, n. 6, p. 299-308, 2002.

TAKEUCHI, M.; HAMANA, K.; HIRAISHI, A. Proposal of the genus Sphingomonas sensu stricto and three new genera, Sphingobium, Novosphingobium and Sphingopyxis, on the basis of phylogenetic and chemotaxonomic analyses. International Journal of Systematic and Evolutionary Microbiology, v. 51, n. 4, July 1, 2001, p. 1405-17, 2001.

TANAKA, Y.; HANADA, S.; MANOME, A.; TSUCHIDA, T.; KURANE, R.; NAKAMURA, K.; KAMAGATA, Y. Catellibacterium nectariphilum gen. nov., sp nov., which requires a diffusible compound from a strain related to the genus Sphingomonas for vigorous growth. International Journal of Systematic and Evolutionary Microbiology, v. 54, May, p. 955-959, 2004.

TARTAKOVSKY, B.; MANUEL, M. F.; BEAUMIER, D.; GREER, C. W.; GUIOT, S. R. Enhanced selection of an anaerobic pentachlorophenol-degrading consortium. Biotechnology and Bioengineering, v. 73, n. 6, p. 476-483, 2001.

TOLLS, J.; HALLER, M.; SEINEN, W.; SIJM, D. T. H. M. LAS bioconcentration: Tissue distribution and effect of hardness: Implications for processes. Environmental Science and Technology, v. 34, n. 2, p. 304-310, 2000.

TOPP, E.; CRAWFORD, R. L.; HANSON, R. S. Influence of readily metabolizable carbon on pentachlorophenol metabolism by a pentachlorophenol-degrading Flavobacterium sp. Applied and Environmental Microbiology, v. 54, n. 10, October 1, 1988, p. 2452-2459, 1988.

TOUZEL, J. P.; ALBAGNAC, G. Isolation and characterization of Methanococcus-mazei strain MC3. FEMS Microbiology Letters, v. 16, n. 2-3, p. 241-245, 1983.

TRAINA, S. J.; MCAVOY, D. C.; VERSTEEG, D. J. Association of linear alkylbenzenesulfonates with dissolved humic substances and its effect on bioavailability. Environmental Science \& Technology, v. 30, n. 4, p. 1300-1309, 1996. 
TURNER, S.; PRYER, K. M.; MIAO, V. P. W.; PALMER, J. D. Investigating Deep Phylogenetic Relationships among Cyanobacteria and Plastids by Small Subunit rRNA Sequence Analysis. Journal of Eukaryotic Microbiology, v. 46, n. 4, p. 327-338, 1999.

UNZ, R. F.; FARRAH, S. R. Use of aromatic-compounds for growth and isolation of Zoogloea. Applied Microbiology, v. 23, n. 3, 1972, p. 524-\&, 1972.

VANDAMME, P.; FALSEN, E.; ROSSAU, R.; HOSTE, B.; SEGERS, P.; TYTGAT, R.; DELEY, J. Revision of Campylobacter, Helicobacter, and Wolinella taxonomy - emendation of generic descriptions and proposal of Arcobacter gen-nov. International Journal of Systematic Bacteriology, v. 41, n. 1, Jan, p. 88-103, 1991.

VAZOLLER, R. F. Avaliação do ecossistema microbiano de um biodigestor anaeróbio de fluxo ascendente e manta de lodo, operado com vinhaça sob condições termofílicas. Tese (Doutorado). Escola de Engenharia de São Carlos, Universidade de São Paulo. São Carlos, 1995.

VOS, P. D.; GARRITY, G.; JONES, D.; KRIEG, N. R.; LUDWIG, W.; RAINEY, F. A.; SCHLEIFER, K. H.; WHITMAN, W. B. Bergey's Manual of Systematic Bacteriology. 2. ed. New York: Springer, v. 3, 2009 (The Firmicutes)

WANG, C. T.; CHOU, W. L.; KUO, Y. M. Removal of COD from laundry wastewater by electrocoagulation/electroflotation. Journal of Hazardous Materials, v. 164, n. 1, p. 81-86, 2009.

WANG, Q. H.; KUNINOBU, M.; OGAWA, H. I.; KATO, Y. Degradation of volatile fatty acids in highly efficient anaerobic digestion. Biomass \& Bioenergy, v. 16, n. 6, p. 407-416, 1999.

WANG, X. J.; SONG, Y.; MAI, J. S. Combined Fenton oxidation and aerobic biological processes for treating a surfactant wastewater containing abundant sulfate. Journal of Hazardous Materials, v. 160, n. 2-3, Dec, p. 344-348, 2008.

WESTALL, J. C.; CHEN, H.; ZHANG, W. J.; BROWNAWELL, B. J. Sorption of linear alkylbenzenesulfonates on sediment materials. Environmental Science \& Technology, v. 33, n. 18, p. 3110-3118, 1999.

WOLF, W.; FEIJTEL, T. Terrestrial risk assessment for linear alkyl benzene sulfonate (LAS) in sludge-amended soils. Chemosphere, v. 36, n. 6, p. 1319-1343, 1998.

WU, W. M.; JAIN, M. K.; MACARIO, E. C.; THIELE, J. H.; ZEIKUS, J. G. Microbial composition and characterization of prevalent methanogens and acetogens isolated from syntrophic methanogenic granules. Applied Microbiology and Biotechnology, v. 38, n. 2, p. 282-290, 1992.

XIE, C. H.; YOKOTA, A. Dyella japonica gen. nov., sp nov a gamma-proteobacterium isolated from soil. International Journal of Systematic and Evolutionary Microbiology, v. 55, Mar, p. 753-756, 2005a. 
XIE, C. H.; YOKOTA, A. Pleomorphomonas oryzae gen. nov., sp nov., a nitrogen-fixing bacterium isolated from paddy soil of Oryza sativa. International Journal of Systematic and Evolutionary Microbiology, v. 55, May, p. 1233-1237, $2005 \mathrm{~b}$.

XIE, C. H.; YOKOTA, A. Reclassification of Alcaligenes latus strains IAM 12599(T) and IAM 12664 and Pseudomonas saccharophila as Azohydromonas lata gen. nov., comb. nov., Azohydromonas australica sp nov and Pelomonas saccharophila gen. nov., comb. nov., respectively. International Journal of Systematic and Evolutionary Microbiology, v. 55, Nov, p. 2419-2425, 2005c.

YAMADA, T.; IMACHI, H.; OHASHI, A.; HARADA, H.; HANADA, S.; KAMAGATA, Y.; SEKIGUCHI, Y. Bellilinea caldifistulae gen. nov., sp. nov. and Longilinea arvoryzae gen. nov., sp. nov., strictly anaerobic, filamentous bacteria of the phylum Chloroflexi isolated from methanogenic propionate-degrading consortia. International Journal of Systematic and Evolutionary Microbiology, v. 57, n. 10, October 1, 2007, p. 2299-2306, 2007.

YAMADA, T.; SEKIGUCHI, Y.; HANADA, S.; IMACHI, H.; OHASHI, A.; HARADA, H.; KAMAGATA, Y. Anaerolinea thermolimosa sp nov., Levilinea saccharolytica gen. nov., sp nov and Leptolinea tardivitalis gen. nov., so. nov., novel filamentous anaerobes, and description of the new classes Anaerolineae classis nov and Caldilineae classis nov in the bacterial phylum Chloroflexi. International Journal of Systematic and Evolutionary Microbiology, v. 56, Jun, p. 1331-1340, 2006.

YING, G. G. Fate, behavior and effects of surfactants and their degradation products in the environment. Environment International, v. 32, n. 3, p. 417-431, 2006.

YOON, J.; MATSUO, Y.; ADACHI, K.; NOZAWA, M.; MATSUDA, S.; KASAI, H.; YOKOTA, A. Description of Persicirhabdus sediminis gen. nov., sp. nov., Roseibacillus ishigakijimensis gen. nov., sp. nov., Roseibacillus ponti sp. nov., Roseibacillus persicicus sp. nov., Luteolibacter pohnpeiensis gen. nov., sp. nov. and Luteolibacter algae sp. nov., six marine members of the phylum 'Verrucomicrobia', and emended descriptions of the class Verrucomicrobiae, the order Verrucomicrobiales and the family Verrucomicrobiaceae. International Journal of Systematic and Evolutionary Microbiology, v. 58, n. 4, April 1, 2008, p. 998-1007, 2008.

YOON, M. H.; IM, W. T. Flavisolibacter ginsengiterrae gen. nov., sp. nov. and Flavisolibacter ginsengisoli sp. nov., isolated from ginseng cultivating soil. International Journal of Systematic and Evolutionary Microbiology, v. 57, n. 8, August 1, 2007, p. 18341839, 2007.

ZELLNER, G.; BOONE, D. R.; KESWANI, J.; WHITMAN, W. B.; WOESE, C. R.; HAGELSTEIN, A.; TINDALL, B. J.; STACKEBRANDT, E. Reclassification of Methanogenium tationis and Methanogenium liminatans as Methanofollis tationis gen. nov., comb. nov. and Methanofollis liminatans comb. nov. and description of a new strain of Methanofollis liminatans. International Journal of Systematic Bacteriology, v. 49, n. 1, January 1, 1999, p. 247-255, 1999.

ZELLNER, G.; KNEIFEL, H.; WINTER, J. Oxidation of benzaldehydes to benzoic-acid derivatives by three Desulfovibrio strains. Applied and Environmental Microbiology, v. 56, n. 7, Jul, p. 2228-2233, 1990. 
ZELLNER, G.; MESSNER, P.; KNEIFEL, H.; WINTER, J. Desulfovibrio simplex spec. nov., a new sulfate-reducing bacterium from a sour whey digester. Archives of Microbiology, v. 152, n. 4, p. 329-334, 1989.

ZHANG, J.; ZHENG, J. W.; HANG, B. J.; NI, Y. Y.; HE, J.; LI, S. P. Rhodanobacter xiangquanii sp. nov., a Novel Anilofos-Degrading Bacterium Isolated from a Wastewater Treating System. Current Microbiology, v. 62, n. 2, p. 645-649, 2011.

ZHANG, P.; CHEN, Y. G.; HUANG, T. Y.; ZHOU, Q. Waste activated sludge hydrolysis and short-chain fatty acids accumulation in the presence of SDBS in semi-continuous flow reactors: Effect of solids retention time and temperature. Chemical Engineering Journal, v. 148, n. 2-3, May, p. 348-353, 2009. 


\section{APÊNDICES}

Tabela A.1: Lista de gêneros classificados segundo o RDP-Classifier

\begin{tabular}{|c|c|c|c|}
\hline & Ordem & Família & Gênero \\
\hline \multicolumn{4}{|l|}{ Domínio Archaea } \\
\hline \multicolumn{4}{|l|}{ Filo Euryarchaeota } \\
\hline \multirow{4}{*}{$\begin{array}{l}\text { Classe Methanomi- } \\
\text { crobia }\end{array}$} & Methanomicrobiales & Methanomicrobiaceae & Methanofollis \\
\hline & Methanomicrobiales & Methanomicrobiaceae & Methanosphaerula \\
\hline & Methanomicrobiales & Methanomicrobiales_incertae_sedis & Methanolinea \\
\hline & Methanomicrobiales & Methanospirillaceae & Methanospirillum \\
\hline \multicolumn{4}{|l|}{ Domínio Bacteria } \\
\hline \multicolumn{4}{|l|}{ Filo Acidobacteria } \\
\hline \multirow[t]{2}{*}{ Classe Holophagae } & Holophagales & Holophagaceae & Geothrix \\
\hline & Holophagales & Holophagaceae & Holophaga \\
\hline \multicolumn{4}{|l|}{ Filo Actinobacteria } \\
\hline \multirow[t]{5}{*}{ Classe Actinobacteria } & Actinomycetales & Geodermatophilaceae & Geodermatophilus \\
\hline & Actinomycetales & Mycobacteriaceae & Mycobacterium \\
\hline & Actinomycetales & Nocardioidaceae & Nocardioides \\
\hline & Solirubrobacterales & Conexibacteraceae & Conexibacter \\
\hline & Solirubrobacterales & Solirubrobacteraceae & Solirubrobacter \\
\hline \multicolumn{4}{|l|}{ Filo Bacteroidetes } \\
\hline \multirow[t]{4}{*}{ Classe Bacteroidia } & Bacteroidales & Porphyromonadaceae & Dysgonomonas \\
\hline & Bacteroidales & Porphyromonadaceae & Paludibacter \\
\hline & Bacteroidales & Porphyromonadaceae & Parabacteroides \\
\hline & Bacteroidales & Porphyromonadaceae & Petrimonas \\
\hline \multirow[t]{2}{*}{ Classe Flavobacteria } & Flavobacteriales & Cryomorphaceae & Fluviicola \\
\hline & Flavobacteriales & Flavobacteriaceae & Flavobacterium \\
\hline \multirow{5}{*}{$\begin{array}{l}\text { Classe Sphingobacte- } \\
\text { ria }\end{array}$} & Sphingobacteriales & Chitinophagaceae & Chitinophaga \\
\hline & Sphingobacteriales & Chitinophagaceae & Ferruginibacter \\
\hline & Sphingobacteriales & Chitinophagaceae & Flavisolibacter \\
\hline & Sphingobacteriales & Chitinophagaceae & Sediminibacterium \\
\hline & Sphingobacteriales & Chitinophagaceae & Terrimonas \\
\hline \multicolumn{4}{|l|}{ Filo Chlamydiae } \\
\hline Classe Chlamydiae & Chlamydiales & Parachlamydiaceae & Neochlamydia \\
\hline \multicolumn{4}{|l|}{ Filo Chloroflexi } \\
\hline \multirow[t]{4}{*}{ Classe Anaerolineae } & Anaerolineales & Anaerolineaceae & Bellilinea \\
\hline & Anaerolineales & Anaerolineaceae & Leptolinea \\
\hline & Anaerolineales & Anaerolineaceae & Levilinea \\
\hline & Anaerolineales & Anaerolineaceae & Longilinea \\
\hline Classe Caldilineae & Caldilineales & Caldilineaceae & Caldilinea \\
\hline $\begin{array}{l}\text { Classe } \\
\text { Thermomicrobia }\end{array}$ & Sphaerobacterales & Sphaerobacteraceae & Sphaerobacter \\
\hline \multicolumn{4}{|l|}{ Filo Deferribacteres } \\
\hline $\begin{array}{l}\text { Classe Deferribacte- } \\
\text { res }\end{array}$ & Deferribacterales & Deferribacteraceae & Denitrovibrio \\
\hline \multirow[t]{2}{*}{ Classe Bacilli } & Bacillales & Bacillaceae & Lentibacillus \\
\hline & Lactobacillales & Carnobacteriaceae & Atopostipes \\
\hline
\end{tabular}


Tabela A1 - Lista de gêneros classificados segundo o RDP-Classifier (cont.)

\begin{tabular}{|c|c|c|c|}
\hline & Ordem & Família & Gênero \\
\hline \multicolumn{4}{|l|}{ Domínio Bacteria } \\
\hline \multicolumn{4}{|l|}{ Filo Firmicutes (cont.) } \\
\hline \multirow[t]{17}{*}{ Classe Clostridia } & Clostridiales & Clostridiaceae & Clostridium \\
\hline & Clostridiales & Clostridiaceae & Oxobacter \\
\hline & Clostridiales & Eubacteriaceae & Anaerofustis \\
\hline & Clostridiales & Eubacteriaceae & Eubacterium \\
\hline & Clostridiales & Eubacteriaceae & Pseudoramibacter \\
\hline & Clostridiales & Incertae Sedis XI & Gallicola \\
\hline & Clostridiales & Incertae Sedis XI & Sedimentibacter \\
\hline & Clostridiales & Incertae Sedis XI & Soehngenia \\
\hline & Clostridiales & Incertae Sedis XII & Fusibacter \\
\hline & Clostridiales & Incertae Sedis XIII & Anaerovorax \\
\hline & Clostridiales & Peptostreptococcaceae & Sporacetigenium \\
\hline & Clostridiales & Syntrophomonadaceae & Syntrophomonas \\
\hline & Clostridiales & Veillonellaceae & Megasphaera \\
\hline & Clostridiales & Veillonellaceae & Pectinatus \\
\hline & Clostridiales & Veillonellaceae & Propionispira \\
\hline & Clostridiales & Veillonellaceae & Propionispora \\
\hline & Clostridiales & Veillonellaceae & Sporomusa \\
\hline \multicolumn{4}{|l|}{ Filo Fusobacteria } \\
\hline Classe Fusobacteria & Fusobacteriales & Fusobacteriaceae & Cetobacterium \\
\hline \multicolumn{4}{|c|}{ Filo Gemmatimonadetes } \\
\hline $\begin{array}{l}\text { Classe Gemmatimona- } \\
\text { detes }\end{array}$ & Gemmatimonadales & Gemmatimonadaceae & Gemmatimonas \\
\hline \multicolumn{4}{|l|}{ Filo Lentisphaerae } \\
\hline Classe Lentisphaeria & Victivallales & Victivallaceae & Victivallis \\
\hline \multicolumn{4}{|l|}{ Filo Planctomycetes } \\
\hline Classe & Planctomycetales & Planctomycetaceae & Blastopirellula \\
\hline \multirow[t]{4}{*}{ Planctomycetacia } & Planctomycetales & Planctomycetaceae & Pirellula \\
\hline & Planctomycetales & Planctomycetaceae & Planctomyces \\
\hline & Planctomycetales & Planctomycetaceae & Rhodopirellula \\
\hline & Planctomycetales & Planctomycetaceae & Singulisphaera \\
\hline \multicolumn{4}{|l|}{ Filo Proteobacteria } \\
\hline Classe Alphaproteo- & Caulobacterales & Caulobacteraceae & Brevundimonas \\
\hline bacteria & Caulobacterales & Caulobacteraceae & Caulobacter \\
\hline & Caulobacterales & Caulobacteraceae & Phenylobacterium \\
\hline & Rhizobiales & Beijerinckiaceae & Chelatococcus \\
\hline & Rhizobiales & Bradyrhizobiaceae & Afipia \\
\hline & Rhizobiales & Bradyrhizobiaceae & Bosea \\
\hline & Rhizobiales & Bradyrhizobiaceae & Bradyrhizobium \\
\hline & Rhizobiales & Bradyrhizobiaceae & Nitrobacter \\
\hline & Rhizobiales & Bradyrhizobiaceae & Rhodopseudomonas \\
\hline & Rhizobiales & Brucellaceae & Brucella \\
\hline & Rhizobiales & Brucellaceae & Ochrobactrum \\
\hline & Rhizobiales & Hyphomicrobiaceae & Blastochloris \\
\hline & Rhizobiales & Hyphomicrobiaceae & Devosia \\
\hline & Rhizobiales & Hyphomicrobiaceae & Hyphomicrobium \\
\hline & Rhizobiales & Hyphomicrobiaceae & Prosthecomicrobium \\
\hline & Rhizobiales & Methylocystaceae & Pleomorphomonas \\
\hline & Rhizobiales & Rhodobiaceae & Parvibaculum \\
\hline & Rhizobiales & Xanthobacteraceae & Pseudolabrys \\
\hline & Rhizobiales & Xanthobacteraceae & Starkeya \\
\hline
\end{tabular}


Tabela A1 - Lista de gêneros classificados segundo o RDP-Classifier (cont.)

\begin{tabular}{|c|c|c|c|}
\hline & Ordem & Família & Gênero \\
\hline \multicolumn{4}{|l|}{ Domínio Bacteria } \\
\hline \multicolumn{4}{|l|}{ Filo Proteobacteria } \\
\hline \multirow{10}{*}{$\begin{array}{l}\text { Classe Alphaproteo- } \\
\text { bacteria (cont.) }\end{array}$} & Rhodobacterales & Rhodobacteraceae & Albidovulum \\
\hline & Rhodobacterales & Rhodobacteraceae & Catellibacterium \\
\hline & Rhodobacterales & Rhodobacteraceae & Paracoccus \\
\hline & Rhodospirillales & Acetobacteraceae & Roseomonas \\
\hline & Rhodospirillales & Acetobacteraceae & Stella \\
\hline & Rhodospirillales & Rhodospirillaceae & Azospirillum \\
\hline & Rhodospirillales & Rhodospirillaceae & Magnetospirillum \\
\hline & Rhodospirillales & Rhodospirillaceae & Oceanibaculum \\
\hline & Sphingomonadales & Sphingomonadaceae & Sphingopyxis \\
\hline & Sphingomonadales & Sphingomonadaceae & Sphingosinicella \\
\hline \multirow{22}{*}{$\begin{array}{l}\text { Classe Betaproteobacte- } \\
\text { ria }\end{array}$} & Burkholderiales & Alcaligenaceae & Achromobacter \\
\hline & Burkholderiales & Alcaligenaceae & Azohydromonas \\
\hline & Burkholderiales & Alcaligenaceae & Pigmentiphaga \\
\hline & Burkholderiales & Burkholderiales_incertae_sedis & Methylibium \\
\hline & Burkholderiales & Comamonadaceae & Brachymonas \\
\hline & Burkholderiales & Comamonadaceae & Comamonas \\
\hline & Burkholderiales & Comamonadaceae & Diaphorobacter \\
\hline & Burkholderiales & Comamonadaceae & Hydrogenophaga \\
\hline & Burkholderiales & Comamonadaceae & Simplicispira \\
\hline & Burkholderiales & Comamonadaceae & Variovorax \\
\hline & Burkholderiales & Oxalobacteraceae & Herminiimonas \\
\hline & Hydrogenophilales & Hydrogenophilaceae & Thiobacillus \\
\hline & Nitrosomonadales & Nitrosomonadaceae & Nitrosomonas \\
\hline & Nitrosomonadales & Nitrosomonadaceae & Nitrosospira \\
\hline & Rhodocyclales & Rhodocyclaceae & Azoarcus \\
\hline & Rhodocyclales & Rhodocyclaceae & Azonexus \\
\hline & Rhodocyclales & Rhodocyclaceae & Azospira \\
\hline & Rhodocyclales & Rhodocyclaceae & Dechloromonas \\
\hline & Rhodocyclales & Rhodocyclaceae & Denitratisoma \\
\hline & Rhodocyclales & Rhodocyclaceae & Propionivibrio \\
\hline & Rhodocyclales & Rhodocyclaceae & Shinella \\
\hline & Rhodocyclales & Rhodocyclaceae & Zoogloea \\
\hline \multirow{15}{*}{$\begin{array}{l}\text { Classe Deltaproteo- } \\
\text { bacteria }\end{array}$} & Bdellovibrionales & Bdellovibrionaceae & Bdellovibrio \\
\hline & Desulfobacterales & Desulfobacteraceae & Desulfonema \\
\hline & Desulfobacterales & Desulfobulbaceae & Desulfobulbus \\
\hline & Desulfovibrionales & Desulfomicrobiaceae & Desulfomicrobium \\
\hline & Desulfovibrionales & Desulfovibrionaceae & Desulfovibrio \\
\hline & Desulfuromonadales & Desulfuromonadaceae & Desulfuromonas \\
\hline & Desulfuromonadales & Geobacteraceae & Geobacter \\
\hline & Myxococcales & Cystobacteraceae & Hyalangium \\
\hline & Myxococcales & Phaselicystidaceae & Phaselicystis \\
\hline & Myxococcales & Polyangiaceae & Chondromyces \\
\hline & Myxococcales & Polyangiaceae & Sorangium \\
\hline & Syntrophobacterales & Syntrophaceae & Desulfomonile \\
\hline & Syntrophobacterales & Syntrophaceae & Smithella \\
\hline & Syntrophobacterales & Syntrophobacteraceae & Desulfovirga \\
\hline & Syntrophobacterales & Syntrophobacteraceae & Syntrophobacter \\
\hline \multirow{2}{*}{$\begin{array}{l}\text { Classe Epsilonproteo- } \\
\text { bacteria }\end{array}$} & Campylobacterales & Campylobacteraceae & Arcobacter \\
\hline & Campylobacterales & Helicobacteraceae & Sulfuricurvum \\
\hline
\end{tabular}


Tabela A1 - Lista de gêneros classificados segundo o RDP-Classifier (cont.)

\begin{tabular}{clll}
\hline & Ordem & Família & Gênero \\
\hline Domínio Bacteria & & & \\
Filo Proteobacteria (cont.) & & & \\
Classe Gammaproteobacteria & Aeromonadales & Aeromonadaceae & Aeromonas \\
& Alteromonadales & Shewanellaceae & Shewanella \\
& Legionellales & Legionellaceae & Fluoribacter \\
& Methylococcales & Methylococcaceae & Methylomonas \\
& Pseudomonadales & Moraxellaceae & Acinetobacter \\
& Pseudomonadales & Pseudomonadaceae & Pseudomonas \\
& Xanthomonadales & Xanthomonadaceae & Dyella \\
& Xanthomonadales & Xanthomonadaceae & Pseudoxanthomonas \\
& Xanthomonadales & Xanthomonadaceae & Rhodanobacter \\
& Xanthomonadales & Xanthomonadaceae & Stenotrophomonas \\
& Xanthomonadales & Xanthomonadaceae & Thermomonas \\
Filo Spirochaetes & Spirochaetales & Leptospiraceae & Leptonema \\
Classe Spirochaetes & Spirochaetales & Spirochaetaceae & Spirochaeta \\
Filo Synergistetes & & & \\
Classe Synergistia & Synergistales & Synergistaceae & Aminiphilus \\
& Synergistales & Synergistaceae & Aminobacterium \\
& Synergistales & Synergistaceae & Aminomonas \\
& Synergistales & Synergistaceae & Cloacibacillus \\
Filo Thermotogae & Synergistales & Synergistaceae & Synergistes \\
Classe Thermotogae & Thermotogales & Thermotogaceae & Kosmotoga \\
Filo Verrucomicrobia & & & \\
Classe Opitutae & Opitutales & Opitutaceae & Opitutus \\
Classe Verrucomicrobiae & Verrucomicrobiales & Verrucomicrobiaceae & Luteolibacter \\
& Verrucomicrobiales & Verrucomicrobiaceae & Prosthecobacter \\
\hline & & &
\end{tabular}


Tabela A2: UTOs atribuídas a cada gênero, com respectivos limites de confiança (segundo o RDP-Classifier), abundância relativa e referências usadas para caracterização microbiana

\begin{tabular}{|c|c|c|c|c|c|c|c|}
\hline Gênero & UTOs & $\begin{array}{l}\text { Limite de } \\
\text { confiança }\end{array}$ & $\begin{array}{c}\text { ML-R }{ }_{\mathrm{L} 1} \\
(\%)\end{array}$ & $\begin{array}{c}\mathrm{SF}-\mathrm{R}_{\mathrm{L} 1} \\
(\%)\end{array}$ & $\begin{array}{c}\mathrm{ML}_{\mathrm{S} 1} \mathrm{R}_{\mathrm{S}} \\
(\%)\end{array}$ & $\begin{array}{c}\text { SF-R } 1 \\
(\%) \\
\end{array}$ & Referências \\
\hline Achromobacter & 533 & 0,51 & 0,05 & - & - & 0,02 & Brenner et al. (2005) \\
\hline Acinetobacter & 234 & 1 & 0,06 & - & - & - & $\begin{array}{l}\text { Cook (1998); Brenner et al. (2005); } \\
\text { Abboud et al. (2007) }\end{array}$ \\
\hline Aeromonas & $\begin{array}{l}902 \\
510\end{array}$ & $\begin{array}{l}0,98 \\
0,99\end{array}$ & - & - & 0,07 & 0,55 & $\begin{array}{l}\text { Jimenez et al. (1991); Denger e Cook } \\
\text { (1999); Brenner et al. (2005) }\end{array}$ \\
\hline Afipia & $\begin{array}{l}148 \\
320 \\
460 \\
624\end{array}$ & $\begin{array}{c}0,78 \\
0,55 \\
0,97 \\
0,5\end{array}$ & 0,02 & 0,20 & 0,01 & 1,53 & Brenner et al. (2005) \\
\hline Albidovulum & 157 & 0,54 & - & - & - & 0,02 & Albuquerque et al. (2002) \\
\hline Aminiphilus & $\begin{array}{c}12 \\
515 \\
770 \\
299\end{array}$ & $\begin{array}{c}1 \\
1 \\
1 \\
0,98\end{array}$ & - & 0,04 & 5,06 & 1,35 & Diaz et al. (2007) \\
\hline Aminobacterium & 426 & 0,56 & - & - & 0,04 & - & Baena et al. (1998) \\
\hline Aminomonas & $\begin{array}{c}18 \\
816 \\
162 \\
\end{array}$ & $\begin{array}{c}1 \\
0,53 \\
0,56\end{array}$ & 0,75 & - & 1,06 & 0,02 & $\begin{array}{l}\text { Baena et al. (1999); Duarte et al. } \\
\text { (2008); Duarte } \text { et al. (2010b); } \\
\text { Delforno et al. (2012) }\end{array}$ \\
\hline Anaerofustis & $\begin{array}{l}518 \\
688 \\
\end{array}$ & $\begin{array}{l}0,89 \\
0,89 \\
\end{array}$ & 0,54 & - & 0,22 & - & Vos et al. (2009) \\
\hline Anaerovorax & 879 & 0,79 & - & 0,02 & - & 0,02 & $\begin{array}{l}\text { Duarte et al. (2008); Vos et al. } \\
\text { (2009); }\end{array}$ \\
\hline Arcobacter & 933 & 1 & - & - & 0,06 & 0,73 & $\begin{array}{l}\text { Vandamme } \text { et al. (1991); Brenner } \text { et } \\
\text { al. (2005); Houf } \text { et al. }(2005) ; \\
\text { Delforno } \text { et al. }(2012)\end{array}$ \\
\hline Atopostipes & 773 & 0,83 & - & 0,02 & - & - & Vos et al. (2009) \\
\hline Azoarcus & 28 & 0,97 & - & - & - & 0,02 & $\begin{array}{l}\text { Gescher et al. (2002); Brenner et al. } \\
(2005)\end{array}$ \\
\hline Azohydromonas & $\begin{array}{l}338 \\
340\end{array}$ & $\begin{array}{l}0,63 \\
0,56\end{array}$ & - & 0,04 & - & 0,08 & Xie e Yokota (2005c) \\
\hline Azonexus & $\begin{array}{l}101 \\
253 \\
583\end{array}$ & $\begin{array}{c}0,9 \\
0,99 \\
0,98 \\
\end{array}$ & 0,28 & 0,27 & 0,04 & - & Brenner et al. (2005) \\
\hline Azospira & $\begin{array}{l}115 \\
184 \\
304 \\
613 \\
736 \\
757 \\
438 \\
\end{array}$ & $\begin{array}{c}0,5 \\
0,87 \\
0,56 \\
0,62 \\
0,55 \\
0,7 \\
1 \\
\end{array}$ & 0,15 & 0,05 & 0,06 & 3,03 & $\begin{array}{l}\text { Brenner et al. (2005); Duarte } \text { et al. } \\
\text { (2008) }\end{array}$ \\
\hline Azospirillum & 635 & 0,98 & - & - & - & 0,11 & Brenner et al. (2005) \\
\hline Bdellovibrio & $\begin{array}{l}266 \\
403\end{array}$ & $\begin{array}{c}1 \\
0,95\end{array}$ & - & - & - & 0,15 & Brenner et al. (2005) \\
\hline Bellilinea & $\begin{array}{c}5 \\
185 \\
212 \\
280 \\
492 \\
600 \\
800 \\
\end{array}$ & $\begin{array}{l}0,53 \\
0,53 \\
0,75 \\
0,52 \\
0,56 \\
0,78 \\
0,64\end{array}$ & 0,35 & - & 0,05 & 0,02 & Yamada et al. (2007) \\
\hline Blastochloris & 926 & 0,87 & 0,02 & - & - & - & Brenner et al. (2005) \\
\hline Blastopirellula & 935 & 0,65 & - & - & 0,01 & - & Krieg et al. (2010) \\
\hline
\end{tabular}


Tabela A2: UTOs atribuídas a cada gênero, com respectivos limites de confiança (segundo o RDP-Classifier), abundância relativa e referências usadas para caracterização microbiana (cont.)

\begin{tabular}{|c|c|c|c|c|c|c|c|}
\hline Gênero & UTOs & $\begin{array}{l}\text { Limite de } \\
\text { confiança }\end{array}$ & $\begin{array}{l}\mathrm{ML}-\mathrm{R}_{\mathrm{L} 1} \\
(\%)\end{array}$ & $\begin{array}{l}\mathrm{SF}-\mathrm{R}_{\mathrm{L} 1} \\
(\%)\end{array}$ & $\begin{array}{l}\text { ML-R }_{S 1} \\
(\%)\end{array}$ & $\begin{array}{l}\text { SF-R } \\
(\%)\end{array}$ & Referências \\
\hline \multirow[t]{6}{*}{ Bosea } & 63 & 0,94 & \multirow[t]{6}{*}{0,39} & \multirow[t]{6}{*}{0,05} & \multirow[t]{6}{*}{-} & \multirow[t]{6}{*}{1,14} & \multirow{6}{*}{$\begin{array}{l}\text { Ouattara et al. (2003); Brenner et } \\
\text { al. }(2005)\end{array}$} \\
\hline & 174 & 0,92 & & & & & \\
\hline & 182 & 1 & & & & & \\
\hline & 632 & 0,98 & & & & & \\
\hline & 844 & 1 & & & & & \\
\hline & 912 & 1 & & & & & \\
\hline Brachymonas & 159 & 0,76 & 0,02 & - & 0,01 & - & Brenner et al. (2005) \\
\hline Bradyrhizobium & 65 & 0,75 & - & - & - & 0,02 & Brenner et al. (2005) \\
\hline \multirow[t]{4}{*}{ Brevundimonas } & 105 & 0,99 & \multirow[t]{4}{*}{0,89} & \multirow[t]{4}{*}{0,07} & \multirow[t]{4}{*}{-} & \multirow[t]{4}{*}{-} & Segers et al. (1994); Hong e \\
\hline & 195 & 0,93 & & & & & Raushel (1996); Brenner et al. \\
\hline & 473 & 1 & & & & & (2005); Kang et al. (2009) \\
\hline & 802 & 0,98 & & & & & \\
\hline Brucella & 593 & 0,98 & - & - & 0,04 & 0,13 & Brenner et al. (2005) \\
\hline \multirow[t]{5}{*}{ Caldilinea } & 85 & 0,5 & \multirow[t]{5}{*}{0,23} & \multirow[t]{5}{*}{-} & \multirow[t]{5}{*}{0,07} & \multirow[t]{5}{*}{-} & \multirow[t]{5}{*}{ Sekiguchi et al. (2003) } \\
\hline & 369 & 0,8 & & & & & \\
\hline & 507 & 0,63 & & & & & \\
\hline & 779 & 0,56 & & & & & \\
\hline & 903 & 0,56 & & & & & \\
\hline Catellibacterium & 612 & 0,6 & - & - & - & 0,02 & Tanaka et al. (2004) \\
\hline \multirow[t]{2}{*}{ Caulobacter } & 61 & 1 & 0,14 & 0,32 & 0,01 & - & Brenner et al. (2005); Duarte et al. \\
\hline & 363 & 0,76 & & & & & $(2010 b)$ \\
\hline Cetobacterium & 167 & 0,9 & - & - & 0,01 & - & Krieg et al. (2010) \\
\hline Chelatococcus & 817 & 0,89 & 0,06 & 0,23 & 0,01 & - & Brenner et al. (2005) \\
\hline & 894 & 0,98 & & & & & \\
\hline Chitinophaga & 317 & 0,67 & - & - & - & 0,42 & Krieg et al. (2010) \\
\hline & 575 & 0,68 & & & & & \\
\hline Chondromyces & 723 & 0,76 & - & - & - & 0,08 & Brenner et al. (2005) \\
\hline & 884 & 0,76 & & & & & \\
\hline Cloacibacillus & 682 & 0,58 & - & - & 0,01 & 0,02 & Ganesan et al. (2008) \\
\hline Clostridium & 32 & 0,83 & 0,03 & 0,02 & 0,01 & - & Hsu et al. (1990); Cook (1998); \\
\hline & 421 & 0,89 & & & & & Mechichi et al. (1999); Chien et \\
\hline & & & & & & & al. (2005); Mechichi et al. (2005); \\
\hline & & & & & & & Lara-Martin et al. (2007); Duarte \\
\hline & & & & & & & et al. (2008); Vos et al. (2009); \\
\hline & & & & & & & $\begin{array}{l}\text { Duarte et al. (2010b); Oliveira et } \\
\text { al. }(2010) \text {; }\end{array}$ \\
\hline Comamonas & 358 & 0,54 & - & 0,32 & 0,11 & 3,48 & Cook (1998); Schleheck et al. \\
\hline & 633 & 0,81 & & & & & (2004a); Brenner et al. (2005); \\
\hline & & & & & & & Schleheck et al. (2010) \\
\hline Conexibacter & 215 & 0,89 & - & - & - & 0,02 & Monciardini et al. (2003) \\
\hline Dechloromonas & 692 & 0,5 & 0,02 & 0,47 & - & 1,84 & Achenbach et al. (2001); Brenner \\
\hline & 695 & 0,86 & & & & & et al. (2005); Delforno et al. \\
\hline & 877 & 0,57 & & & & & (2012); Duarte et al. (2010a); \\
\hline & & & & & & & Chakraborty et al. (2005); \\
\hline & & & & & & & Chakraborty e Coates (2005); \\
\hline & & & & & & & Salinero et al.(2009) \\
\hline Denitratisoma & 424 & 0,89 & - & 0,02 & - & - & Fahrbach et al. (2006) \\
\hline Denitrovibrio & 592 & 0,57 & - & - & 0,01 & - & Myhr e Torsvik (2000) \\
\hline Desulfobulbus & 48 & 1 & 1,68 & 5,65 & 0,02 & - & Brenner et al. (2005) \\
\hline & 401 & 1 & & & & & \\
\hline & 730 & 1 & & & & & \\
\hline Desulfomicrobium & 246 & 1 & 0,48 & 0,04 & 0,05 & - & Brenner et al. (2005) \\
\hline & 755 & 0,99 & & & & & \\
\hline & 832 & 1 & & & & & \\
\hline
\end{tabular}


Tabela A2: UTOs atribuídas a cada gênero, com respectivos limites de confiança (segundo o RDP-Classifier), abundância relativa e referências usadas para caracterização microbiana (cont.)

\begin{tabular}{|c|c|c|c|c|c|c|c|}
\hline Gênero & UTOs & $\begin{array}{l}\text { Limite de } \\
\text { confiança }\end{array}$ & $\begin{array}{l}\mathrm{ML}-\mathrm{R}_{\mathrm{L} 1} \\
(\%)\end{array}$ & $\begin{array}{c}\mathrm{SF}-\mathrm{R}_{\mathrm{L} 1} \\
(\%)\end{array}$ & $\begin{array}{l}\mathrm{ML}-\mathrm{R}_{\mathrm{S} 1} \\
(\%)\end{array}$ & $\begin{array}{c}\text { SF-R } \\
(\%)\end{array}$ & Referências \\
\hline \multirow[t]{3}{*}{ Desulfomonile } & 191 & 0,55 & 0,08 & - & - & - & Brenner et al. (2005) \\
\hline & 797 & 0,97 & & & & & \\
\hline & 542 & 0,53 & & & & & \\
\hline \multirow[t]{2}{*}{ Desulfonema } & 354 & 0,74 & 0,15 & - & 0,09 & - & Brenner et al. (2005) \\
\hline & 883 & 0,78 & & & & & \\
\hline \multirow[t]{8}{*}{ Desulfovibrio } & 87 & 0,94 & 4,81 & 0,91 & 0,46 & 1,14 & Zellner et al. (1989); Zellner et al. \\
\hline & 290 & 0,72 & & & & & (1990); Reichenbecher et al. \\
\hline & 480 & 0,88 & & & & & (1997); Cook (1998); Brenner et \\
\hline & 539 & 1 & & & & & al. (2005); Duarte et al. (2010a) \\
\hline & 691 & 0,52 & & & & & \\
\hline & 737 & 1 & & & & & \\
\hline & 928 & 0,98 & & & & & \\
\hline & 254 & 0,99 & & & & & \\
\hline Desulfovirga & 321 & 0,5 & 0,03 & - & 0,01 & - & Brenner et al. (2005) \\
\hline \multirow[t]{2}{*}{ Desulfuromonas } & 462 & 0,82 & 0,82 & 0,13 & - & - & Brenner et al. (2005) \\
\hline & 501 & 0,74 & & & & & \\
\hline Devosia & 60 & 0,91 & - & 0,04 & - & - & Brenner et al. (2005) \\
\hline \multirow[t]{3}{*}{ Diaphorobacter } & 40 & 0,56 & - & 0,04 & - & 0,45 & Tabrez Khan e Hiraishi (2002) \\
\hline & 587 & 0,58 & & & & & \\
\hline & 885 & 0,59 & & & & & \\
\hline Dyella & 760 & 0,81 & 0,02 & 0,05 & - & 0,03 & Xie e Yokota (2005a) \\
\hline Dysgonomonas & 687 & 1 & - & - & 0,01 & 0,02 & Krieg et al. (2010) \\
\hline Eubacterium & 265 & 0,61 & - & - & 0,01 & - & Vos et al. (2009) \\
\hline \multirow{2}{*}{ Ferruginibacter } & 446 & 0,62 & - & 0,97 & - & 1,03 & Lim et al. (2009) \\
\hline & 521 & 0,58 & & & & & \\
\hline Flavisolibacter & 75 & 0,78 & - & - & - & 0,18 & Yoon e Im (2007) \\
\hline Flavobacterium & 173 & 0,91 & - & - & 0,02 & 0,48 & $\begin{array}{l}\text { Duarte et al. (2010a); Krieg et al. } \\
\text { (2010) }\end{array}$ \\
\hline Fluoribacter & 671 & 0,61 & - & 0,04 & - & - & Garrity et al. (1980) \\
\hline Fluviicola & 872 & 0,97 & - & - & - & 0,02 & Krieg et al. (2010) \\
\hline Fusibacter & 336 & 0,68 & 1,20 & 0,09 & 0,02 & 0,11 & Vos et al. (2009) \\
\hline Gallicola & 565 & 0,76 & 0,42 & - & 0,05 & - & Vos et al. (2009) \\
\hline \multirow[t]{4}{*}{ Gemmatimonas } & 152 & 0,79 & - & 1,31 & - & 0,23 & Krieg et al. (2010) \\
\hline & 310 & 0,78 & & & & & \\
\hline & 547 & 1 & & & & & \\
\hline & 745 & 0,87 & & & & & \\
\hline \multirow[t]{3}{*}{ Geobacter } & 13 & 0,94 & 0,05 & 0,02 & 0,02 & 0,02 & Brenner et al. (2005); Lara-Martin \\
\hline & 699 & $1 ; 1$ & & & & & et al. (2007); Delforno et al. (2012) \\
\hline & 768 & & & & & & \\
\hline Geodermatophilus & 307 & 0,57 & - & - & - & 0,02 & Luedeman (1968) \\
\hline \multirow[t]{2}{*}{ Geothrix } & 378 & 0,61 & 0,02 & 0,09 & - & - & Krieg et al. (2010) \\
\hline & 619 & 0,54 & & & & & \\
\hline Herminiimonas & 660 & 1 & 0,02 & - & - & - & Fernandes et al. (2005) \\
\hline
\end{tabular}


Tabela A2: UTOs atribuídas a cada gênero, com respectivos limites de confiança (segundo o RDP - Classifier), abundância relativa e referências usadas para caracterização da comunidade microbiana (cont.)

\begin{tabular}{|c|c|c|c|c|c|c|c|}
\hline Gênero & UTOs & $\begin{array}{l}\text { Limite de } \\
\text { confiança }\end{array}$ & $\begin{array}{l}\text { ML-R }{ }_{\mathrm{L} 1} \\
(\%)\end{array}$ & $\begin{array}{l}\text { SF-R } \mathrm{L}_{\mathrm{L} 1} \\
(\%)\end{array}$ & $\begin{array}{l}\mathrm{ML}_{\mathrm{S}} \mathrm{R}_{\mathrm{S}} \\
(\%)\end{array}$ & $\begin{array}{l}\text { SF-R } \\
(\%)\end{array}$ & Referências \\
\hline Holophaga & $\begin{array}{c}73 \\
79 \\
176 \\
203 \\
285 \\
397 \\
474 \\
505 \\
544 \\
659 \\
834 \\
929 \\
\end{array}$ & $\begin{array}{c}0,52 \\
0,5 \\
0,63 \\
0,73 \\
0,63 \\
0,7 \\
0,64 \\
0,59 \\
0,66 \\
0,69 \\
0,83 \\
0,51 \\
\end{array}$ & 3,27 & 4,48 & 0,21 & 2,93 & $\begin{array}{l}\text { Liesack et al. (1994); Oliveira et al. } \\
\text { (2009); Krieg et al. (2010) }\end{array}$ \\
\hline Hyalangium & 873 & 0,5 & - & 0,20 & - & 0,03 & Brenner et al. (2005) \\
\hline Hydrogenophaga & 651 & 0,92 & 0,02 & 0,39 & - & - & $\begin{array}{l}\text { Dangmann et al. (1989); Cook } \\
\text { (1998); Brenner et al. (2005) }\end{array}$ \\
\hline Hyphomicrobium & $\begin{array}{l}283 \\
839\end{array}$ & $\begin{array}{l}0,99 \\
0,97\end{array}$ & - & - & 0,02 & 0,05 & Brenner et al. (2005) \\
\hline Kosmotoga & $\begin{array}{l}257 \\
932 \\
529 \\
272 \\
\end{array}$ & $\begin{array}{c}0,73 \\
0,82 \\
0,7 \\
0,83 \\
\end{array}$ & 0,96 & 0,02 & 1,55 & - & DiPippo et al. (2009) \\
\hline Lentibacillus & 586 & 0,54 & 0,02 & - & - & - & Vos et al. (2009) \\
\hline Leptolinea & $\begin{array}{c}98 \\
416 \\
513 \\
550 \\
865 \\
800 \\
\end{array}$ & $\begin{array}{c}0,5 \\
0,5 \\
0,74 \\
0,58 \\
0,59 \\
0,64\end{array}$ & 5,73 & 0,16 & 4,03 & 0,02 & Yamada et al. (2006) \\
\hline Leptonema & $\begin{array}{c}7 \\
629 \\
201 \\
\end{array}$ & $\begin{array}{l}1 \\
1 \\
1\end{array}$ & - & 1,25 & 0,02 & 0,05 & Krieg et al. (2010) \\
\hline Levilinea & $\begin{array}{l}350 \\
391 \\
\end{array}$ & $\begin{array}{c}1 \\
0,68 \\
\end{array}$ & 0,02 & 0,02 & - & - & Yamada et al. (2006) \\
\hline Longilinea & $\begin{array}{c}97 \\
146 \\
206 \\
223 \\
250 \\
296 \\
330 \\
335 \\
535 \\
677 \\
727\end{array}$ & $\begin{array}{c}0,53 \\
0,85 \\
0,71 \\
0,58 \\
0,82 \\
0,53 \\
0,94 \\
0,55 \\
0,5 \\
0,95 \\
0,58\end{array}$ & 3,94 & - & 0,91 & 0,02 & Yamada et al. (2007) \\
\hline Luteolibacter & 857 & 0,86 & - & - & 0,25 & 0,10 & Yoon et al. (2008) \\
\hline Magnetospirillum & $\begin{array}{l}309 \\
382 \\
823 \\
826\end{array}$ & $\begin{array}{c}1 \\
1 \\
1 \\
0,99\end{array}$ & - & 0,07 & 0,01 & 1,03 & Brenner et al. (2005) \\
\hline Megasphaera & 548 & 1 & 0,02 & - & - & - & Vos et al. (2009) \\
\hline Methanofollis & 808 & 0,53 & - & - & 0,04 & - & Zellner et al. (1999) \\
\hline Methanolinea & $\begin{array}{l}282 \\
648\end{array}$ & $\begin{array}{c}0,72 \\
0,9\end{array}$ & 0,03 & - & - & - & Imachi et al. (2008) \\
\hline
\end{tabular}


Tabela A2: UTOs atribuídas a cada gênero, com respectivos limites de confiança (segundo o RDP-Classifier), abundância relativa e referências usadas para caracterização microbiana (cont.)

\begin{tabular}{|c|c|c|c|c|c|c|c|}
\hline Gênero & UTOs & $\begin{array}{l}\text { Limite de } \\
\text { confiança }\end{array}$ & $\begin{array}{l}\mathrm{ML}-\mathrm{R}_{\mathrm{L} 1} \\
(\%)\end{array}$ & $\begin{array}{l}\text { SF-R }{ }_{\mathrm{L} 1} \\
(\%)\end{array}$ & $\begin{array}{l}\mathrm{ML}-\mathrm{R}_{\mathrm{S} 1} \\
(\%)\end{array}$ & $\begin{array}{l}\text { SF-R } \\
(\%)\end{array}$ & Referências \\
\hline Methanosphaerula & 717 & 0,56 & 0,06 & - & 0,14 & - & Cadillo-Quiroz et al. (2009) \\
\hline Methanospirillum & $\begin{array}{l}388 \\
684 \\
869\end{array}$ & $\begin{array}{c}1 \\
0,92 \\
0,85\end{array}$ & 0,08 & 0,02 & 0,02 & 0,03 & $\begin{array}{l}\text { Falkow et al. (2006); Duarte } e t \\
\text { al. (2010a) }\end{array}$ \\
\hline Methylibium & 389 & 0,95 & - & 0,04 & - & - & Nakatsu et al. (2006) \\
\hline Methylomonas & $\begin{array}{c}76 \\
420\end{array}$ & $\begin{array}{c}1 \\
0,99\end{array}$ & - & 0,43 & - & 0,02 & Brenner et al. (2005) \\
\hline Mycobacterium & 9 & 1 & 0,03 & - & - & - & $\begin{array}{l}\text { Falkow et al. (2006); Oliveira et } \\
\text { al. (2010) }\end{array}$ \\
\hline Neochlamydia & 546 & 0,82 & 0,03 & - & - & - & Krieg et al. (2010) \\
\hline Nitrobacter & $\begin{array}{l}433 \\
828\end{array}$ & $\begin{array}{l}0,68 \\
0,58\end{array}$ & 0,02 & - & - & 0,02 & Brenner et al. (2005) \\
\hline Nitrosomonas & $\begin{array}{c}38 \\
104 \\
145 \\
384 \\
404 \\
489 \\
881 \\
827 \\
806 \\
573 \\
499 \\
520 \\
561 \\
493 \\
\end{array}$ & $\begin{array}{c}0,85 \\
0,84 \\
0,68 \\
0,7 \\
0,53 \\
0,77 \\
0,76 \\
0,63 \\
0,97 \\
0,91 \\
0,64 \\
0,56 \\
0,82 \\
0,5\end{array}$ & 0,02 & 0,97 & 0,05 & 34,11 & $\begin{array}{l}\text { Keener e Arp (1994); Brandt et } \\
\text { al. (2001); Brenner } \text { et al. }(2005)\end{array}$ \\
\hline Nitrosospira & $\begin{array}{l}218 \\
346\end{array}$ & $\begin{array}{c}1 \\
0,79\end{array}$ & - & - & - & 0,05 & $\begin{array}{l}\text { Brandt et al. (2001); Brenner et } \\
\text { al. (2005); }\end{array}$ \\
\hline Nocardioides & 33 & 0,99 & - & - & - & 0,02 & Prauser (1976) \\
\hline Oceanibaculum & 787 & 0,56 & - & - & - & 0,02 & Lai et al. (2009) \\
\hline Ochrobactrum & 890 & 0,93 & - & - & - & 0,02 & Brenner et al. (2005) \\
\hline Opitutus & $\begin{array}{l}436 \\
789\end{array}$ & 0,$89 ; 1$ & - & 0,02 & 0,04 & 0,27 & $\begin{array}{l}\text { Duarte et al. (2010a); Krieg et } \\
\text { al. (2010); }\end{array}$ \\
\hline Oxobacter & $\begin{array}{c}26 \\
123 \\
230 \\
713\end{array}$ & $\begin{array}{l}0,77 \\
0,68 \\
0,51 \\
0,86\end{array}$ & 0,12 & - & 0,10 & - & Vos et al. (2009) \\
\hline Paludibacter & 630 & 0,64 & - & - & - & 0,02 & Krieg et al. (2010) \\
\hline Parabacteroides & 408 & 0,8 & - & - & 0,01 & 0,08 & Sakamoto e Benno (2006) \\
\hline Paracoccus & $\begin{array}{l}395 \\
566\end{array}$ & $\begin{array}{l}0,68 \\
0,67\end{array}$ & - & - & - & 0,05 & Brenner et al. (2005) \\
\hline Parvibaculum & 890 & 0,93 & 0,02 & - & 0,02 & 1,23 & $\begin{array}{l}\text { Dong et al. (2004); Schleheck et } \\
\text { al. }(2004 \mathrm{a}) ; \text { Schleheck et al. } \\
(2004 \mathrm{~b}) ; \text { Schleheck e Cook } \\
\text { (2005); Martinez-Pascual et al. } \\
(2010)\end{array}$ \\
\hline Pectinatus & 302 & 0,99 & 0,02 & - & - & - & Vos et al. (2009) \\
\hline Petrimonas & 605 & 1 & - & - & - & 0,05 & Krieg et al. (2010) \\
\hline Phaselicystis & 895 & 0,81 & - & 0,07 & - & - & Garcia et al. (2009) \\
\hline
\end{tabular}


Tabela A2: UTOs atribuídas a cada gênero, com respectivos limites de confiança (segundo o RDP-Classifier), abundância relativa e referências usadas para caracterização microbiana (cont.)

\begin{tabular}{|c|c|c|c|c|c|c|c|}
\hline Gênero & UTOs & $\begin{array}{l}\text { Limite de } \\
\text { confiança }\end{array}$ & $\begin{array}{c}\text { ML-R }{ }_{\mathrm{L} 1} \\
(\%)\end{array}$ & $\begin{array}{c}\mathrm{SF}-\mathrm{R}_{\mathrm{L} 1} \\
(\%)\end{array}$ & $\begin{array}{c}\mathrm{ML}_{\mathrm{S}} \mathrm{R}_{\mathrm{S}} \\
(\%)\end{array}$ & $\begin{array}{l}\text { SF-R } \\
(\%)\end{array}$ & Referências \\
\hline \multirow{7}{*}{ Phenylobacterium } & 149 & 1 & \multirow[t]{7}{*}{0,08} & \multirow[t]{7}{*}{1,85} & \multirow[t]{7}{*}{0,07} & \multirow[t]{7}{*}{1,31} & \multirow{7}{*}{$\begin{array}{l}\text { Brenner et al. (2005); Sanchez- } \\
\text { Peinado et al. (2010) }\end{array}$} \\
\hline & 188 & 0,61 & & & & & \\
\hline & 249 & 0,99 & & & & & \\
\hline & 297 & 0,7 & & & & & \\
\hline & 349 & 0,93 & & & & & \\
\hline & 478 & 0,98 & & & & & \\
\hline & 528 & 1 & & & & & \\
\hline Pigmentiphaga & 29 & 1 & - & 0,04 & - & 0,02 & Brenner et al. (2005) \\
\hline Pirellula & 748 & 0,52 & - & - & 0,01 & - & Krieg et al. (2010) \\
\hline Planctomyces & 432 & 0,94 & - & 0,02 & - & - & Krieg et al. (2010) \\
\hline Pleomorphomonas & 593 & 0,98 & 0,05 & - & 0,11 & 0,13 & $\begin{array}{l}\text { Xie e Yokota (2005b); Duarte et } \\
\text { al. (2008); Duarte } \text { et al. (2010b) }\end{array}$ \\
\hline Propionispira & 319 & 0,99 & - & - & 0,01 & - & Vos et al. (2009) \\
\hline Propionispora & 864 & 1 & - & - & 0,05 & - & Vos et al. (2009) \\
\hline \multirow[t]{2}{*}{ Propionivibrio } & 374 & 0,79 & \multirow[t]{2}{*}{-} & \multirow[t]{2}{*}{0,04} & \multirow[t]{2}{*}{0,01} & \multirow[t]{2}{*}{0,03} & \multirow[t]{2}{*}{ Brenner et al. (2005) } \\
\hline & 836 & 0,9 & & & & & \\
\hline \multirow[t]{2}{*}{ Prosthecobacter } & 555 & 0,99 & \multirow[t]{2}{*}{-} & \multirow[t]{2}{*}{1,79} & \multirow[t]{2}{*}{-} & \multirow[t]{2}{*}{-} & \multirow[t]{2}{*}{ Krieg et al. (2010) } \\
\hline & 640 & 1 & & & & & \\
\hline Prosthecomicrobium & 568 & 0,73 & - & 0,05 & - & - & Brenner et al. (2005) \\
\hline Pseudolabrys & 926 & 0,87 & - & 0,07 & - & 0,02 & Kämpfer et al. (2006) \\
\hline \multirow[t]{9}{*}{ Pseudomonas } & 131 & 1 & \multirow[t]{9}{*}{3,39} & 0,18 & 2,29 & 3,45 & Lode e Coon (1971); Jimenez et \\
\hline & 318 & 0,99 & & & & & al. (1991); Sigoillot e Nguyen \\
\hline & 329 & 0,96 & & & & & (1992); Beilen et al. (1994); Cook \\
\hline & 498 & 0,57 & & & & & (1998); Kertesz et al. (1999); \\
\hline & 527 & 0,68 & & & & & Stover et al. (2000); Almendariz \\
\hline & 751 & 0,89 & & & & & et al. (2001); Brenner et al. \\
\hline & 791 & 0,91 & & & & & (2005); Lara-Martin et al. (2007); \\
\hline & 897 & 0,54 & & & & & Duarte et al. (2010a); Martinez- \\
\hline & 248 & 0,79 & & & & & Pascual et al. (2010) \\
\hline Pseudoramibacter & 905 & 0,79 & 0,02 & - & 0,05 & - & Vos et al. (2009) \\
\hline Pseudoxanthomonas & 414 & 1 & 0,05 & 0,02 & 0,04 & 0,23 & Brenner et al. (2005) \\
\hline Rhodanobacter & 353 & 1 & - & - & - & 7,27 & Brenner et al. (2005); Zhang et al. \\
\hline & 368 & 0,64 & & & & & $(2011)$ \\
\hline & 488 & 0,94 & & & & & \\
\hline & 594 & 1 & & & & & \\
\hline & 739 & 0,53 & & & & & \\
\hline & 82 & 0,54 & & & & & \\
\hline & 364 & 0,94 & & & & & \\
\hline Rhodopirellula & 452 & 0,51 & - & - & 0,02 & - & Krieg et al. (2010) \\
\hline Rhodopseudomonas & 568 & 0,73 & - & - & - & 0,02 & $\begin{array}{l}\text { Harwood e Gibson (1988); } \\
\text { Brenner et al. (2005) }\end{array}$ \\
\hline Roseomonas & 366 & 1 & 0,03 & 0,05 & - & 0,47 & Brenner et al. (2005) \\
\hline & 411 & 1 & & & & & \\
\hline & 511 & 0,69 & & & & & \\
\hline & 776 & 0,8 & & & & & \\
\hline Sedimentibacter & 241 & 1 & - & - & 0,01 & - & $\begin{array}{l}\text { Lara-Martin et al. (2007); Vos et } \\
\text { al. (2009) }\end{array}$ \\
\hline Sediminibacterium & 450 & 1 & - & 0,13 & - & - & Qu e Yuan (2008) \\
\hline Shewanella & 801 & 1 & - & - & 0,01 & 0,02 & Brenner et al. (2005) \\
\hline Shinella & 281 & 1 & - & - & 0,04 & 0,03 & An et al. (2006) \\
\hline Simplicispira & 153 & 0,97 & - & 0,11 & - & 0,13 & Lu et al. (2007) \\
\hline Singulisphaera & 400 & 0,81 & - & - & - & 0,02 & Krieg et al. (2010) \\
\hline
\end{tabular}


Tabela A2: UTOs atribuídas a cada gênero, com respectivos limites de confiança (segundo o RDP-Classifier), abundância relativa e referências usadas para caracterização microbiana (cont.)

\begin{tabular}{|c|c|c|c|c|c|c|c|}
\hline Gênero & UTOs & $\begin{array}{l}\text { Limite de } \\
\text { confiança }\end{array}$ & $\begin{array}{l}\mathrm{ML}-\mathrm{R}_{\mathrm{L} 1} \\
(\%)\end{array}$ & $\begin{array}{c}\mathrm{SF}-\mathrm{R}_{\mathrm{L} 1} \\
(\%)\end{array}$ & $\begin{array}{l}\mathrm{ML}-\mathrm{R}_{\mathrm{S} 1} \\
(\%)\end{array}$ & $\begin{array}{l}\text { SF-R } \\
(\%)\end{array}$ & Referências \\
\hline Smithella & $\begin{array}{c}418 \\
90 \\
708 \\
803 \\
822 \\
838 \\
908 \\
323 \\
\end{array}$ & $\begin{array}{c}0,85 \\
1 \\
0,6 \\
0,57 \\
0,98 \\
0,91 \\
0,99 \\
0,52\end{array}$ & 0,35 & 0,09 & 0,16 & - & $\begin{array}{l}\text { Brenner et al. (2005); } \\
\text { Delforno et al. }(2012)\end{array}$ \\
\hline Soehngenia & $\begin{array}{c}58 \\
181\end{array}$ & $\begin{array}{c}0,96 \\
1\end{array}$ & - & - & 0,21 & 0,45 & $\begin{array}{l}\text { Parshina et al. (2003); Vos et } \\
\text { al. (2009) }\end{array}$ \\
\hline Solirubrobacter & 534 & 0,7 & - & - & 0,01 & - & Singleton et al. (2003) \\
\hline Sorangium & 69 & 0,54 & - & - & - & 0,06 & Brenner et al. (2005) \\
\hline Sphaerobacter & 52 & 0,54 & - & - & - & 0,03 & $\begin{array}{l}\text { Demharter et al. (1989); } \\
\text { Hugenholtz e } \\
\text { Stackebrandt(2004); Pati et al. } \\
\text { (2010) }\end{array}$ \\
\hline Sphingopyxis & 690 & 0,61 & - & - & - & 0,05 & Takeuchi et al. (2001) \\
\hline Sphingosinicella & 244 & 1 & - & 0,02 & - & - & Maruyama et al. (2006) \\
\hline Spirochaeta & 880 & 0,9 & 0,02 & - & 0,01 & - & Krieg et al. (2010) \\
\hline Sporacetigenium & 187 & 0,51 & 0,11 & - & - & - & Chen et al. (2006) \\
\hline Sporomusa & $\begin{array}{l}229 \\
405 \\
417 \\
608 \\
771 \\
835\end{array}$ & $\begin{array}{c}1 \\
1 \\
0,93 \\
1 \\
0,95 \\
1\end{array}$ & 0,37 & 0,02 & 3,74 & 1,23 & $\begin{array}{l}\text { Vos et al. (2009); Delforno et } \\
\text { al. (2012) }\end{array}$ \\
\hline Starkeya & 60 & 0,91 & 0,03 & 0,02 & - & - & Kelly et al. (2000) \\
\hline Stella & 861 & 1 & - & - & - & 0,03 & Brenner et al. (2005) \\
\hline Stenotrophomonas & 829 & 1 & - & - & 0,16 & 0,24 & $\begin{array}{l}\text { Brenner et al. (2005); Lara- } \\
\text { Martin et al. (2007) }\end{array}$ \\
\hline Sulfuricurvum & $\begin{array}{l}132 \\
208\end{array}$ & $\begin{array}{c}0,99 \\
1\end{array}$ & - & - & 0,10 & - & Kodama e Watanabe (2004) \\
\hline Synergistes & $\begin{array}{l}256 \\
293 \\
445 \\
611 \\
661 \\
896 \\
260 \\
\end{array}$ & $\begin{array}{l}0,92 \\
0,68 \\
0,74 \\
0,74 \\
0,68 \\
0,63 \\
0,84\end{array}$ & 2,02 & - & 5,52 & 0,10 & $\begin{array}{l}\text { Allison et al. (1992); Kumar } \\
\text { et al. (2010) }\end{array}$ \\
\hline Syntrophobacter & $\begin{array}{l}238 \\
275 \\
467 \\
541 \\
686 \\
749 \\
428\end{array}$ & $\begin{array}{c}0,95 \\
0,85 \\
1 \\
0,63 \\
0,96 \\
0,89 \\
0,93\end{array}$ & 1,09 & - & 0,04 & - & $\begin{array}{l}\text { Boone e Bryant (1980); } \\
\text { Tartakovsky et al. }(2001) \text {; } \\
\text { Brenner et al. }(2005) ; \text { Duarte } \\
\text { et al. (2010a); Duarte } \text { et al. } \\
\text { (2010b) }\end{array}$ \\
\hline Syntrophomonas & 540 & 0,96 & 0,02 & - & 0,01 & - & $\begin{array}{l}\text { McInerney et al. (1981); Vos } \\
\text { et al. (2009) }\end{array}$ \\
\hline Terrimonas & $\begin{array}{l}110 \\
193 \\
490 \\
\end{array}$ & $\begin{array}{c}0,87 \\
1 \\
0,91 \\
\end{array}$ & - & 0,11 & - & 0,05 & $\begin{array}{l}\text { Krieg et al. (2010); Oliveira et } \\
\text { al. }(2010)\end{array}$ \\
\hline Thermomonas & $\begin{array}{c}46 \\
781\end{array}$ & $\begin{array}{c}1 \\
0,78\end{array}$ & - & - & 0,07 & 0,29 & $\begin{array}{l}\text { Busse et al. (2002); Brenner et } \\
\text { al. (2005) }\end{array}$ \\
\hline Thiobacillus & 614 & 1 & - & 0,05 & - & 0,34 & Brenner et al. (2005) \\
\hline
\end{tabular}


Tabela A2: UTOs atribuídas a cada gênero, com respectivos limites de confiança (segundo o RDP-Classifier), abundância relativa e referências usadas para caracterização microbiana (cont.)

\begin{tabular}{lccccccl}
\hline Gênero & UTOs & $\begin{array}{c}\text { Limite de } \\
\text { confiança }\end{array}$ & $\begin{array}{c}\text { ML-R } \\
(\%)\end{array}$ & $\begin{array}{c}\text { SF-R } \\
(\%)\end{array}$ & $\begin{array}{c}\text { ML-R } \\
(\%)\end{array}$ & $\begin{array}{c}\text { SF-R } \\
(\%)\end{array}$ & Referência \\
\hline Variovorax & 620 & 0,99 & - & 0,07 & - & - & $\begin{array}{l}\text { Brenner } \text { et al. (2005); Duarte } \text { et } \\
\text { al. (2010b) }\end{array}$ \\
\hline Victivallis & 437 & 1 & 0,03 & 0,04 & - & 0,15 & Krieg et al. (2010) \\
& 664 & 0,51 & & & & & \\
\hline Zoogloea & 669 & 0,84 & & & & & \\
& 111 & 0,78 & 0,37 & 20,84 & 0,12 & 2,29 & Unz e Farrah (1972); Arvin et al. \\
& 644 & 0,78 & & & & & \\
& 778 & 0,95 & & & & & \\
& 764 & 1 & & & & & \\
& 741 & 0,99 & & & & & \\
& 623 & 1 & & & & & \\
& 136 & 0,97 & & & & & \\
& 168 & 0,99 & & & & & \\
& 271 & 0,85 & & & & & \\
& 287 & 0,99 & & & & & \\
& 543 & 0,94 & & & & & \\
& 385 & 0,81 & & & & & \\
& 313 & 0,99 & & & & & \\
& 852 & 1 & & & & & \\
& 866 & 0,64 & & & & & \\
& 906 & 0,99 & & & & & \\
& 559 & 0,85 & & & & & \\
\end{tabular}

